\title{
Georganiseerde liefde : publieke bemoeienis met zorg in de privésfeer
}

Citation for published version (APA):

van der Lyke, S. M. (2000). Georganiseerde liefde : publieke bemoeienis met zorg in de privésfeer. [, Maastricht University]. Van Arkel. https://doi.org/10.26481/dis.20000511sl

Document status and date:

Published: 01/01/2000

DOI:

10.26481/dis.20000511sl

Document Version:

Publisher's PDF, also known as Version of record

\section{Please check the document version of this publication:}

- A submitted manuscript is the version of the article upon submission and before peer-review. There can be important differences between the submitted version and the official published version of record.

People interested in the research are advised to contact the author for the final version of the publication, or visit the DOI to the publisher's website.

- The final author version and the galley proof are versions of the publication after peer review.

- The final published version features the final layout of the paper including the volume, issue and page numbers.

Link to publication

\footnotetext{
General rights rights.

- You may freely distribute the URL identifying the publication in the public portal. please follow below link for the End User Agreement:

www.umlib.nl/taverne-license

Take down policy

If you believe that this document breaches copyright please contact us at:

repository@maastrichtuniversity.nl

providing details and we will investigate your claim.
}

Copyright and moral rights for the publications made accessible in the public portal are retained by the authors and/or other copyright owners and it is a condition of accessing publications that users recognise and abide by the legal requirements associated with these

- Users may download and print one copy of any publication from the public portal for the purpose of private study or research.

- You may not further distribute the material or use it for any profit-making activity or commercial gain

If the publication is distributed under the terms of Article $25 \mathrm{fa}$ of the Dutch Copyright Act, indicated by the "Taverne" license above, 


\section{Georganiseerde Liefde}

Publieke bemoeienis met zorg in de privésfeer 


\title{
Georganiseerde Liefde
}

Publieke bemoeienis met zorg in de privésfeer

\author{
proefschrift
}

ter verkrijging van de graad van doctor aan de Universiteit Maastricht, op gezag van de Rector Magnificus, Prof. dr. A.C. Nieuwenhuijzen Kruscman volgens het besluit van het college van Decanen, in het openbaar $t^{\circ}$ verdedigen op donderdag II mei $2000 \mathrm{om} \mathrm{I} 4.00 \mathrm{u}$.

\author{
door: \\ Saskia Maria van der Lyke \\ geboren op II oktober 1963 te Hoek (Zeeland)
}




\section{Prometores:}

Prot. dr. J.A.M. Maarse

Prof. dr. H. Philipsen

\section{Co-promutor:}

Dr. K. Horstman

Beoordelingscommissie:

Prof. dr. R. Vos (voorzitter)

Dr. C.W. Busch

Prof. dr. M.S.H. Duijnstec (Universiteit Utrecht)

Prof. dr. C. Spreeuwenberg

Deze uitgave is mede tot stand gekomen dankzij financiële bijdragen van de Groepsraad Fontys Hogescholen, Fontys Hogeschool Verpleegkunde en de J.E. Jurriaanse Stichting.

ISBN 9062244394

(C) Saskia van der Lyke

Illustratic omslag: Jan Lips, Gronsveld

Ontwerp omslag: Marjo Starink, Amsterdam

Druk: Haasbeek, Alphen aan de Rijn

Uitgeverij Jan van Arkel, Alexander Numankade 17, 3572 KP Utrecht telefoon 03027318 40, www.antenna.nl/i-books, e mail i-books@antenna.nl 


\section{Inhoud}

Voorwoord 9

Een impressie $I I$

Georganiseerde Liefde 16

I Beleid en Informele zorg

Inleiding 17

Overheid en informele zorg 20

Argumenten bij stimulering van informele zorg 25

De constructie van werkelijkheden in beleid 27

Intertekstualiteit, representatie en gender 29

Gender en her informele-zorgbeleid 33

Merhode van onderzoek 35

Dara 36

Probleemstelling en vervolg 40

De mantel der liefde 44

2 Zwakke Zorgenden

Inleiding 45

Het belang van informele zorg 46

De kracht van sociale nerwerken so

Een tekort aan verzorgsters 53

Veranderende sociale netwerken 58

Partner en patiënt 63

Ondersteun verzorgers 67

Zwakke zorgenden 70

Thuis 74

3 Verborgen Verzorgers

Inleiding 75

De patiënt kiest 76

Een afhankelijke patiënt 80

Helende huizen 86 
De huis-gevangene $y^{2}$

Verborgen verzorgers 100

Zo mooi mogulijk 102

4 Kundige Leken

Inleiding yo3

Professionals ondersteunen ios

Een wederkerige relatie 108

Gescheiden domeinen II5

Domeinenstrijd II9

Kundige leken 129

Ginungene'n der liufde 134

5 Georganiseerde Liefde

Inleiding 135

Verdwenen relaties 137

Overbelaste vereorgers 140

Professionaliseren van informele zorg 143

Controle op de eigen verantwoordelijkheid I49

Noten 155

Bronnen 187

Bijlage I Geanalyseerde Beleidsdocumenten 187

Bijlage 2 Geanalyseerde Wetenschappelijke Artikelen 188

Bijlage 3 Overzicht Geïnterviewde Verzorgers 194

Literatuur 197

Samenvatring $2 \mathrm{II}$

Summary 215

Curriculum Vitae 219 


\section{Voorwoord}

Toen ik bij de vakgroep beleidswetenschap van de Universiteit Maastricht als assistent in opleiding werd aangesteld, was mijn onderzoek gericht op interorganisarionele netwerken' in de thuiszorg. Nu ligt er een proefschrift over beleid en informele zorg. U begrijpt dat bij de totstandkoming van dit proefschrift geen vastgestelde route is gevolgd. Ik ben van de hoofdweg afgeweken, heb zijpaden bewandeld en stil gestaan op plekken die ik in het proefschrift niet eens noem.

Het ontstaan van dit proefschrift is te danken aan Hans Maarse. Hij heeft me begeleid en vele keren gezucht en gemopperd vanwege mijn eigenwijsheid. $1 \mathrm{k}$ dank hem zeer voor zijn steun, geduld en de manier waarop hij ruimte gaf dit proefschrift op mijn (eigen)wijze vorm te geven. Hij is een goed mens.

Als ervaren promotor heeft Hans Philipsen ons in het traject bijgestaan. Diagonaal lezend, zijn woorden, wist hij steeds zijn vinger op een zere plek te leggen, deed zinvolle suggesties en hakte knopen door. Een ware leermeester.

Klasien Horstman bekeek mijn teksten kritisch. Onder het motto 's-s-s' oftewel: 'schrijven is structureren en schrappen', hielp ze met het ordenen van mijn gedachten, stimuleerde me door te gaan en liet me geloven in de (goede) afloop. Zonder haar had ik het niet gered.

Naast mijn promotores hebben vele collega-vrienden een bijdrage geleverd. Fameus is onze 'aio-soep'. Gedurende heel wat jaren at ik maandelijks, bij wijze van avondmaal, met mijn collega's soep. Dat gaf ons een goede voedingsbodem om een concept-tekst van één van ons te bespreken. Ik dank: Roland Bal, Marc Berg, Marleen Goumans, Michiel van Dorp, Ruud Hendriks, Loes Kater, Nel Knols, Agnes Meershoek, Jessica Mesman, Irma van der Ploeg, Marianne Potting en Marie-Josée Smits. Een kririscher en regelijk inspirerend forum is bijna niet denkbaar.

Tineke Abma, Ruth Benschop, Sandra Kensen, Jeannetre Pols en Perra Toren waren in vroeg of laat stadium zo deskundig en welwillend om mijn teksten op de letter te lezen en van commentaar te voorzien. Veel dank voor de tijd en energie. De uirwisselingen hebben me goed geholpen. Met mijn paranimfen Antoinette de Bont en Rina Vaatstra deelde ik de genoegens en ongenoegens rond deze proeve van bekwaamheid meer dan eens. Omdat zij, net als ik, hun proefschrift afronden terwijl ze buiten de universitaire wereld werkten gaf dat extra verbondenheid.

Toen ik, wat later halverwege het schrijven van dit proefschrift bleek, de overstap maakte van de Maastrichtse werkkring naar Fontys Hogescholen, veranderde niet alleen mijn professionele leven. Daar weten mijn vriendinnen alles van. Karin 
van Dirshuizen, Loes Fermont, Ankie Gommer, Mary-Anne van Heusden, Toos Hokke, Carien van der Lycke en Lineke Polman vormen een reuze sterk netwerk. Speciale woorden voor Jeanette de Jong en Eugenie van Miltenburg. Ik heb hen lief.

Mijn voormalige en huidige baas van Fontys Hogeschool Verpleegkunde respectievelijk Harric Smeets en Mariërte Lips-Keyser dank ik voor her in mij gestelde vertrouwen. Mijn collega's van de vakgroep beleidswetenschap en huidige collega's dank ik voor hun belangstelling. Her boekje is af en ik beloof jullie spannendere vakantieverhalen dan de vorderingen van dit werk. Speciale dank aan Jan Lips die nauwgezet ieder punt en komma heeft bekeken en bovendien het beeld op de voorkant etste. Jenny Welling vertaalde de summary.

Natuurlijk denk ik nog vaak aan de verzorgers die hun persoonlijke en indringende verhaal hebben willen vertellen. Ik kan nog ontroerd raken bij zoveel openharrigheid. Hoewel het voor mij op het moment van interviewen beslist niet duidelijk was hoe het proefschrift vorm zou krijgen, verwacht ik dat ondanks mijn analyse hun belevingen herkenbaar zijn.

Als laatste wil ik mijn naasten noemen. Tjasse-Pieter Dijksterhuis die het aandurfde met mij een relatie aan te gaan en die meer dan wie ook laat zien wat zorgzaamheid betekent. Mijn vader Sjaak, Nel, Ruben en Natascha geven mij voortdurend hun liefde en vertrouwen dat de basis vormt voor een boeiend leven. Het blijft spijtig dat mijn moeder deze mijlpaal niet meebeleeft. Aan haar draag ik dit proefschrift op. 
Het is 10.45 uur wanneer ik een wijkgebouw van het Groene Kruis binnenloop. De wijkverpleegkundige Greet, die ik vanmorgen vergezel, neemt nog vlug een slok van haar koffie. Samen rijden we in haar auto naar een dorp in de buurt. We bezoeken daar meneer Pirson. Hij beeft kanker in terminaal stadium. Greet gaat deze man verzorgen. Ik kijk toe. Voordat ik mee mocht heeft Greet eerst toestemming aan de patiënt en diens familie gevraagd.

In de auto vertelt Greet dat meneer Pirson, volgens haar collega's die dit weekend bij hem zijn geweest, nu wel erg hard achteruit gaat. Ze heeft hem vier dagen niet gezien en is benieuwd hoe het met hem gaat. Wij rijden naar het dorp, ergens in Zuid-Limburg. Toen Greet deze man van een collega 'in begeleiding kreeg', alweer een jaar geleden, heeft ze gezegd dat ze hem alleen wilde begeleiden in het ziekteproces als ze hem ook in de eindfase mocht verzorgen. Ze vindt het fijn om een zorgproces af te maken en haast zich te zeggen dat het ook voor de patiënt fijn is wanneer hij niet teveel verschillende verpleegkundigen en verzorgenden aan het bed ziet.

We rijden ongeveer vijftien minuten. Bij aankomst gaat de deur van een kleine benedenwoning open en begroet de dochter van de patiënt ons. Ze heeft vannacht op de bank geslapen in de woonkamer naast haar vader. Nou ja, geslapen? Ze slaapt toch nooit veel en ze houdt het nog wel vol, zegt ze. Ik kijk in een vriendelijk gezicht met vermoeide ogen. Ze is éen van de drie kinderen van het echtpaar die allen op steenworp afstand van hun ouders wonen. Ieder van hen heeft inmiddels een eigen gezin. Om en om slapen ze's nachts naast hun vader, zodat moeder wat kan slapen. Ook overdag zijn ze veel bij hun ouders. Het is een heel geregel. Toch is het geen verplichting om voor vader te zorgen, zegt de dochter, als ik haar vraag hoe. ze deze tijd ervaart. 'Ik en wij allemaal doen het graag. Je hebt er dan vrede mee als hij gaat.'

Haar vader ligt in bed. Een geleend bed van het Groene Kruis domineert de kamer. Naast hem staat een typisch ziekenhuistafeltje, ook geleend. Het heeft een bruine kleur en een uitklapbaar gedeelte. Z'n vrouw heeft alle 
benodigdheden voor de wasbeurt op dit tafeltje gelegd; zeep, plastic matjes, onderbroek, schone pyjama en een kam. In betrekkelijk korte tijd is dat, zo te zien, routine voor haar geworden. Ze drentelt af en aan met water, teiltjes en bekkentjes.

Meneer Pirson is ziek, heel ziek, zijn gelaatskleur is grauwgeel, hij is broodmager en heeft ingevallen ogen. Nog een weekje te leven misschien, denk ik, me patiënten herinnerend die ik ooit verpleegde. Hij staart als hij spreekt wezenloos ver voor zich uit; een beetje weg van het aardse bestaan. Ondanks dat is hij nog zeer betrokken. Hij regelt alles tot in de puntjes en zegt tegen mij: 'Zuster als ik er straks niet meer ben en $u$ bent in de buurt dan mag u best hier eens koffe komen drinken.' Ik voel me bezwaard te zeggen dat ik onderzoeker ben. Wat doet dat ertoe in deze situatie? Hij wenkt me en ik moet goed kijken. Het koude washandje op zijn voorhoofd doet 'm goed. Het is heerlijk. Ik vraag hem of hij moe is. 'Moe?'zegt hij met vragende stem, Ik weet niet meer wat dat is. Ik ben op en ga straks. Ja, zo is het leven. Wat is het snel gegaan. We hebben een mooi leven gehad.' En hij kijkt liefdevol naar zijn urouw.

Het condoléanceregister zal achter in de kerk komen, er worden geen handen gegeven. De dochter is blij dat hij het zelf regelt en ook z'n vrouw is dankbaar dat ze alles samen bespreken kunnen. 'Dat is weer het voordeel van een lang ziekbed' zucht ze en zegt dan 'maar toch hoop ik voor hem dat het snel gedaan is.' M'n zuster woont hiernaast die is ook weduwe.....en ik denk: ook?

'Heeft $u$ bet in de krant gelezen?' Ze gaan nog meer bezuinigen op het kruiswerk, vraagt mevrouw Pirson. Tja, zegt Greet er moeten weer acht formatieplaatsen weg en dat terwijl het alleen maar drukker wordt. Veel mensen worden oud en ziek en zijn alleenstaand. Ze wast zorgvuldig met de nodige aandacht en voorzichtigheid verder.

Meneer is helder en helpt mee waar hij kan. Het aan-en uitkleden vermoeit hem zichtbaar. Zijn ledematen lijken broos en stijf. Morgen komt de kapper. 'Ik denk dat hij mooi het graf in wil. ledere dag heeft hij in z'n pyjama een kammetje en een zakdoek. Dat wil hij, maar wat moet hij er nog mee?' zegi zijn vrouw en lacht erom. Hij is en blijft wie hij was: een 
keurige man. Z'n dochter aait hem over het hoofd en fluistert lief: hè jong? Ze heeft barstende hoofdpijn, zegt ze, maar wil deze verzorging volhouden en kan maar niet begrijpen dat mensen hun ouders in een verzorgingstehuis doen. Greet zegt dat je daar niet over mag oordelen.

Twee en half jaar geleden is hij voor het eerst geopereerd, zegt mevrouw Pirson. We hebben nog twee mooie jaren gehad. Langzaam is het bergafwaarts gegaan. De maag is weg, de alvleesklier; de lever gedeeltelijk. De lymfes zijn aangetast. Ze vindt het een rotziekte. 'Hij is zo mager en lijkt wel langer.' Zelf heeft ze ook kanker gehad, als een speldeprik zo groot in de baarmoederhals. Ze was er op tijd bij en is bestraald. Dat is alweer 8 jaar geleden.

Terwijl de dochter Greet helpt met de verzorging - ze aait haar vader, neemt slijm uit zijn mond weg en helpt hem in de kussens - praten mevrouw Pirson en ik, over de pastor die iedere dag komt. Hij heeft het sacrament der zieken toegediend. Dat waarderen we, zegt ze. Toch moet ze er om lachen, om die man. 't Is geen man van deze tijd. Hij oordeelt en zegt steeds dat Jezus ook geleden heeft. Daar krijg ik toch geen troost van? Ik moest het kruis van Jezus in mijn man z'n gezichtsveld hangen dan kon hij het steeds zien. Het hangt op de slaapkamer, dat vind ik goed genoeg.

Greet pakt, als meneer Pirson keurig schoon in bed ligt, een spuitbus, waarna een zoete viooltjesgeur de kamer vult. Intussen heeft mevrouw Pirson koffie voor ons gezet. We krijgen er vlaai bij. Lekker eten zegt meneer Pirson, half slapend, tegen ons. Ik voel me, ondanks alle gasturijheid, toch wat onhandig met een stuk gebak op schoot. Meneer Pirson is moe van de inspanning die het wassen met zich mee brengt. Zijn ogen vallen steeds dicht. De nachten zijn het ergst zegt hij, dan is hij wakker en wil vertellen over vroeger. Z'n vrouw of kinderen zeggen dan: 'Ga slapen, maar hij wil praten nu het nog kan.'

Eten houdt meneer Pirson niet meer binnen, hij braakt met grote golwen, bruine vieze troep. Eerst kreeg hij astronautenvoeding maar dat werd niet vergoed door het ziekenfonds, daarom kostte het ons ongeveer frooo,oo per maand. Niet te betalen. Waterijs wil hij nu nog eten daar is ie dol op, lekker koud, zoet en vochtig. Zelfs dat blijft er niet meer in. De urine is 
super geconcentreerd. Z'n huid is al droog, ter voorkoming van decubitus zijn er stevige beschermlagen op z'n billen geplakt, mooi materiaal; superdun en het werkt goed, zegt Greet. In z'n stomazak zit geen ontlasting maar wat wil je ook, bij eet niet.

Mevrouw Pirson zegt dat bij het hier zoveel fijner heeft dan in het ziekenhuis. In dit huis is altijd iemand en daar is hij maar alleen. Er komt niet zoveel bezoek meer, dat willen ze ook niet. 'Dat geklets. mensen verwachten nog antwoord ook en iedereen komt met z'n eigen sores. Nee het is wel goed $z 0 . '$

Ik kijk in het logboek dat op het tafeltje ligt. Per onderwerp een blad papier; medicatie, overdracht, andere hulpverleners. De meeste blaadjes zijn leeg. Slechts één blaadje is zeer minimaal ingevuld. Hier staat kort en bondig de zorg van dat moment beschreven. Meneer in bed verzorgen, wond en stoma. Medicijnen zijn in het beheer van de familie. Ik schrijf er niet meer in', zegt Greet. 'De tijdsbesteding, dat is ongeveer 45 minuten, schrijf ik op. Dat is belangrijk te weten voor mijn collegas. We houden er dan met de planning rekening mee; de rest zien we wel. Wat nodig is doen we.' Greet vult tijdens de koffie snel het wijkadministratiesysteem in. Ze vraagt naar de gezondheid van mevrouw en informeert naar de hoofdpijn van de dochter.

Na de koffe gaan we. De dochter blijft nog even en gaat, als haar kind uit school komt, snel naar huis. Meneer Pirson slaapt al lang en diep. Zo diep dat hij ons niet weg hoort gaan.

In de auto vraag ik, hoe lang nog? 'Ik hoop niet al te lang', zegt Greet, 'een bloeding zou z'n redding zijn. Het liefst in z'n slaap. Maar je weet het nooit. Laatst had ik iemand die 4,5 dag de Cheyne-Stokes adembaling had '. Gelukkig heeft meneer Pirson geen pijn. Hij krijgt morfine.'

Zo, het is twaalf uur geweest, vanmiddag heeft Greet teamvergadering. 'Dat is maar één keer in de week', zegt ze, 'dan verdelen we alle patiënten enzo. Nee, zitten is niks voor mij, laat mij maar bij de mensen zijn. Ik werk fijn in deze streek. De familie is vaak zo goed. Lieve mensen zijn dit hè?' Ik knik. 'Het is een groot verschil met de stad daar hebben ze soms wel go 
mensen per team tegelijk in zorg dan is het begrijpelijk dat veel van mijn collega's ziek worden, dat houdt niemand vol.'

Als ik Greet later nogmaals ontmoet blijkt meneer Pirson een dag na ons bezoek overleden te zijn. 


\section{Georganiseerde Liefde}

Als iemand thuiskomt om te sterven veronderstellen medewerkers van de thuiszorg dat er mantelzorg is. Het is een aardige gedachte maar daar blijft het dan ook bij.

Neem nou het voorstel van de wijkverpleegkundige om mijn broer Gerard's nachts te laten waken aan het bed van mijn vader. Dat was op zich een goed idee. Mijn moeder en ik waren aan het eind van ons latijn, we waren zo moe, zo moe. Ik durfde amper te gaan zitten, zo bang was ik dat ik niet meer overeind zou komen. Nachten achtereen waren we steeds door mijn vader uit bed geroepen. Ik hield mijn ogen nog maar nauwelijks open. Omdat we niet direct nachthulp kregen, opperde de wijkverpleegkundige, mijn broer bij de zorg in te schakelen.

Maar ja, mijn broer en zorgen....je kunt dat toch niet afdwingen? Hij kwam iedere dag wel even binnen en bracht dan wat lekkers mee voor vader, moeder en mij. Hij dronk een kopje thee of koffie en ging weer naar buiten. Zijn tranen kon bij ternauwernood bedwingen. Hij had het er zo moeilijk mee. Dat uurtje per dag kostte hem al zijn energie.

Na papa's dood voelde hij zich heel erg schuldig. Hij voelde zich bezwaard dat hij niet meer voor mijn ouders had gedaan. Hij heeft daardoor maanden niet gewerkt.

Uit een interview van een dochter die voor haar vader zorgde 


\section{Beleid en Informele zorg}

Ieder beroep op eerstelijnsvoorzieningen zal steeds worden afgewogen tegen de mogelijkheden van de hulpuragenden om zelf door middel van onderlinge hulpverlening een oplossing voor de problemen te vinden'.

"Voor 6 procent van alle sterfgevallen die thans intramuraal plaats vinden is thuis sterven een realiseerbaar en gewenst alternatief ${ }^{2}$.

Inleiding

In mei 1998 stond op de voorpagina van de Volkskrant een bericht waarin de thuiszorgorganisatie Eindhoven een patiëntenstop aankondigde voor terminale zorg. Mensen, zoals uit de voorgaande gevalsbeschrijvingen, moesten voortaan wachten op professionele zorg wanneer ze thuis wilden overlijden. Dat het bericht een plaats kreeg op de voorpagina is zeker niet te danken aan de nieuwswaarde van wachtlijsten in de gezondheidszorg. Wachten op een bed in een verpleeghuis, een kamer in een verzorgingshuis of een appartement in een aanleunwoning is eerder regel dan uitzondering. Ook het wachten op een oproep voor een meniscusoperatie, een hartoperatie of een consult bij de kinderarts is alledaags. Waarschijnlijk ligt de nieuwswaarde in de aard van de lijst. Enerzijds betreft het een wachtlijst voor extramurale zorg en nog wel van zorg aan mensen die gaan sterven (hoe te wachten?), anderzijds gaat het niet om geneeskundige hulp maar om een wachtlijst voor hulp van verzorgenden en verplegenden.

Het bericht uit Eindhoven staat niet op zichzelf. Het aantal instellingen in de thuiszorg met een wachtlijst is de laatste jaren roegenomen ${ }^{3}$. Zo blijkt uit recent onderzoek dat $62 \%$ van de ondervraagde instellingen een wachtlijst voor gezinsverzorging heeft, $68 \%$ van de instellingen rantsoencert de zorg ${ }^{4}$. Dit wil zeggen dat burgers minder uren zorg krijgen dan waarvoor ze door zogenoemde 'intakers' of 'indicatieadviseurs' zijn geïndiceerd. In een andere meting bedragen de percentages respectievelijk $69 \%$ en $60 \%$ s. Hoewel wachtlijsten voor huishoudelijke hulp het meest voorkomen, zijn er ook steeds meer wachtenden voor verzorging en verpleging.

Onderzoekers geven meerdere verklaringen voor het bestaan van deze wachtlijsten. Er zou sprake zijn van een toenemende interesse voor thuiszorg, maar tegelijk 
zijn de budgetten hiervoor gekort. Er bestaan wachtlijsten voor opname vanuit de thuissituatie naar verpleeg- of verzorgingshuizen, maar regelijk sturen artsen patiënten steeds sneller weg uit het ziekenhuis. Ook krapte op de arbeidsmarkt, waardoor onvoldoende geschoold personeel aanwezig is, zou van invloed zijn. Het slechte imago van de verzorgende en verplegende beroepen, hun geringe salarissen, hoog ziekteverzuim en beperkte kansen op promotie dragen ertoe bij dat weinig jongeren zich het vak van verzorgende of verpleegkundige eigen willen maken ${ }^{6}$. Onder invloed van deze ontwikkelingen krijgt de thuiszorg een 'stuwmeer aan hulpverzoeken' waaraan ze niet langer kan voldoen.

Waarom is de vraag naar thuiszorg groot? De aantrekkingskracht van thuiszorg schuilt onder meer in het feit dat het een tegenbeweging vormt voor zorg in instituten ${ }^{7}$. Mensen kregein gedurende de twintigste ceuw steeds meer moeite te leven met ziekte en dood ${ }^{8}$. Problemen die men thuis niet meer de baas kon, zoals het overlijden van een naaste, ging men uitbesteden. Taken rond ziekte, sterven en begraven deelden naasten van zieken steeds vaker toe aan professionals die deze in speciaal daarvoor ingerichte ruimtes uitvoerden ${ }^{9}$. Ernstig zieke mensen werden opgenomen in instituten en stierven daar ook. In de jaren tachtig werd een kentering ingezet die erop gericht is ziekte en dood weer meer bij het leven te betrek$\operatorname{ken}^{10}$.

Niet alleen de wens ziekte en dood weer deel van 'het leven' te laten zijn maakt thuiszorg voor burgers in deze tijd aantrekkelijk, ook is langdurige opname in instellingen minder noodzakelijk. Verbeterde medicamenten, technieken of een verbeterde organisarie van thuiszorg impliceren dat permanente bewaking van artsen of verpleegkundigen niet altijd meer noodzakelijk is. Bovendien zou er ook verzet zijn tegen het zogenaamde 'systeemkarakter' dat deze zorginstellingen kenmerkt ". In ziekenhuizen bijvoorbeeld moeten mensen zich overleveren aan het instellingsregime en zijn daarmee afgesloten van het gewone dagelijkse leven. Ze zijn primair patiënt. Dit betekent dat ze niet kunnen opstaan wanneer ze dat willen, niet eten waar ze trek in hebben of wandelen wanneer daartoe behoefte is. In zo' n 'systeemwereld' gaat het vooral om efficiëntie of doelmatigheid, hier tegenover staat 'de leefwereld' waarin betekenisgeving en communicatief handelen centraal staan. Aangezien bij ziekte en zeker bij sterven leefwereldaspecten meer van belang zijn dan systeemaspecten, zou ook daarom de vraag naar (terminale) thuiszorg toenemen ${ }^{12}$.

Thuiszorg is in trek, de wachtlijsten groeien. Toch is de term 'wachtlijst' enigszins curieus. Deze suggereert dat burgeis zelf geen zorgactiviteiten ontplooien. Her lijkt alsof ze bij ziekte (van een naaste) passief zijn. Het tegendeel is waar. Informele verzorgers, ook wel mantelzorg of centrale verzorgers genoemd, verlenen thuis de meeste zorg ${ }^{13}$. Zij verrichten veel praktische taken of tastbare dien- 
sten. Zo verzorgen ze de tuin, brengen de pariënt naar het ziekenhuis of helpen bij lichamelijke verzorging. Dit geldt ook bij terminale patiënten. En hoewel her verzorgen van stervenden thuis niet altijd meevalt, wil een deel van de informele verzorgers juist die zorg zo lang mogelijk zonder hulp van buitenaf geven ${ }^{14}$. Of iemand thuis sterft hangt dus niet alleen af van professionele verzorgers, maar eerst en vooral van de beschikbare informele verzorgers en hun bereidheid zorg te geven 's. Gezinsverzorgenden en wijkverpleegkundigen hebben slechts een beperkt aandeel in de zorg.

Dit proefschrift gaat over informele zorg in het bijzonder voor mensen die thuis aan kanker sterven ${ }^{16}$. Ik zal bestuderen op welke manier de overheid die zorg beïnvloedt. Aangezien het aanbod van informele zorg nauw samenhangt met het aanbod van professionele zorg, in die zin dat een rem op de uitbreiding van professionele zorg een grotere vraag naar informele zorg meebrengt en vice versa, zal ik informele zorg in het kader van (professionele) thuiszorg bespreken.

De studie, waarvan dit proefschrift verslag doet, heeft als doel een relatie te leggen tussen overheidsbeleid en informele zorg. Hoe verhoudt publieke bemoeienis zich met zorg in de privésfecr? Wat betekent bet als de centrale overheid informele aorg stimuleert? Hoe verandert dan de verbouding tussen het publicke en private domein? Andere in Nederland verschenen studies naar informele zorg richten zich vooral op de beleving van verzorgers. Zo is bijvoorbeeld onderzocht of verzorgers van ouderen zich competent achten en hoe professionele verzorgenden hen kunnen ondersteunen 17 . Ook de belasting van informele verzorgers van dementerende ouderen, de hulpbehoefte van partners van patiënten met een chronische aandoening en de aard van de informele zorg bij cva-patiënten is onderzocht ${ }^{\text {i⿱ }}$. Juist vanwege de koppeling tussen overheid en informele zorg onderscheidt deze studie zich van andere Nederlandse studies op dit gebied.

Informele zorg is gedefinieerd als zorg die rechtstreeks voortvloeit uit een sociale relatie. Het staar voor zorg die partners, familie, vrienden of buren geven en voortkomt uit betrokkenheid. Het is 'datgene voor een ander doen wat zij zelf niet kunnen doen zonder dat daar betaling tegenover staat ${ }^{19}$.' Informele zorg vindt plaats binnen een verwantschapsrelatie en is daamee het gevolg van een bestaande relatie. Het wordt geassocieerd met emotie en gaat meestal gepaard met lichamelijke arbeid, het brengt bovendien enige verantwoordelijkheid met zich mee. Wic zorg aan een naaste geeft, doet dit meestal niet omdat iemand zegt dat het moet, maar vooral vanwege intrinsieke, altruïstische motieven zoals liefde, toewijding, vanzelfsprekendheid, plicht of loyaliteit ${ }^{20}$. Het gebeurt doorgaans op basis van een stilzwijgende wederkerigheid ${ }^{2}$. Het geven van informele zorg is daardoor in hoofdzaak 'irrationeel' en 'romantisch'. 
'Informeel zorgbeleid' is (eigenlijk) een paradox. Het beleid tracht dat wat per definitie voortkomt uit vriendschap of verwantschap te formaliseren. Juist vanwege deze paradoxale inzet van het informele zorgbeleid, het formaliseren van informele verwantschap, is het beïnvloeden of stimuleren van informele zorg gecompliceerd en interessant. Hoe intervenieert de overheid binnen bestaande verwantschapsrelaties? Hoe krijgt ze vat op sociale relaties? Hoe beimvloeden beleidsmakers informele zorg? Deze studie wil antwoord geven op bovenstaande vragen.

De titel van dit proefschrift 'Georganiseerde Liefde' beoogt het paradoxale karakter van het informele-zorgbeleid eveneens uit te drukken en aan te scherpen. 'Georganiseerd' verwijst daarbij naar het gestructureerde, systeemmatige en bijna technische karakter dat het informele-zorgbeleid oproept. 'Liefde', een groot woord, is een voorbeeld van een drijfveer om voor iemand te zorgen. Het verwijst naar intrinsieke, altruïstische en moeilijk beïnvloedbare processen. Hoe dergelijke tegenstrijdigheden binnen het informele-zorgbeleid samenkomen en verweven zijn, is onderwerp van deze studie.

In de volgende paragraaf schets ik eerst de contouren van het informele zorgbeleid. Deze schers heeft tot doel inzicht te geven in de vraag hoe de overheid in bestaande verwantschapsrelaties poogt te interveniëren en hoe ze informele zorg stimuleert. Daartoe zal ik een globaal overzicht geven van actoren die de overheid nodig heeft om het informele zorgbeleid gestalte te geven. Het zal duidelijk worden dat de overheid afhankelijk is van vele actoren. Ze moet zich bovendien inspannen deze actoren haar gedachtengoed eigen te laten maken. Zowel de vorming van een netwerk van actoren dat informele zorg stimuleert als 'de bereidheid' tor het geven van informele zorg zijn het resultaat van een specifieke manier waarop relevante beleidsactoren definities over (goede) zorg zijn gaan delen en in protocollen vastleggen.

\section{Overheid en informele zorg}

Het is moeilijk precies aan te geven wanneer een beleid start. In nota's, geschreven rond de jaren tachtig, stelt de overheid voor het eerst als doel informele zorg te bevorderen. In concreto gaat het er dan om de naasten van een patiënt meer en expliciet bij de zorgverlening thuis te betrekken. Dit informele-zorgbeleid is onlosmakelijk verbonden met het eveneens ingezette thuiszorg-beleid. Dus waar de overheid beleidsuitspraken doet over informele zorg gebeurt dit meestal binnen het bredere kader van de stimulering van thuiszorg. Het beleid, gericht op thuiszorg, zet de vraag waar zorg idealiter moet worden verleend centraal. Het 
beleid, gericht op informele zorg, geeft antwoord op de vraag wie die zorg zal geven.

'Naast het voeren van een beleid dat gericht is op versterking van de eerstelijnszorg dient ook te worden gestreefd naar een vermindering van een beroep op de eerstelijn door het vergroten van de mogelijkheden en de motivatie van mensen om zichzelf en elkaar te helpen. Versterking dus van de informele zorg. Hiervoor staan diverse mogelijkheden open en deze verdienen dan ook goed benut en ondersteund te worden. Dit past ons inziens in her kader van een beleid gericht op minder professionele hulp en meer zelfzorg en mantelzorg ${ }^{12}$.'

Als we de beleidsinstrumenten bezien, die de overheid inzer om informele (thuis)zorg te bevorderen, valt op dat het informele-zorgbeleid zich meer kenmerkt door het uitdragen van een bepaald gedachtengoed dan door een sterk ontwikkeld beleidsinstrumentarium, gericht op informele zorgverleners. In die zin is dit beleid meer conceptualiserend dan structurerend, meer een beleidsfilosofie dan een geheel van concrete beleidsmaatregelen. Zo zijn er wel subsidies voor projecten, maar weinig cijfermatig onderbouwde beleidsdoelen of wetrelijke regelingen en sancties voor informele verzorgers. Het door de overheid ingezerte beleidsinstrumentarium bestaat, ten opzichte van de direct betrokkenen, vooral uit een zogenaamde communicatieve vorm van sturing. Oftewel: dit beleid van de overheid bestaat, zeker bij aanvang, voornamelijk uit woorden.

Een sleutelrol in het bevorderen van de informele zorg is weggelegd voor thuiszorgorganisaties; een combinatie van het voormalige kruiswerk en de gezinszorg. Deze organisaties zijn te beschouwen als de institutionele structuur waarvan de overheid gebruik maakt om het aanbieden van professionele thuiszorg aan zieke mensen, te organiseren. Het zijn organisaties waarvan de activiteiten grotendeels uit collectieve middelen worden bekostigd. Juist deze financiële relatie tussen overheid en zorgorganisaties geeft de overheid over hen, zeker in vergelijking tot de informele verzorgers, meer zeggenschap.

Het overheidsbeleid ten aanzien van de thuiszorg staat al enige jaren in het teken van kostenbeheersing en bezuinigingen. Kostenbeheersing tracht de overheid te bereiken door thuiszorgorganisaties te dwingen hun doelmatigheid (betere prijs-kwaliteit-verhouding) te vergroten. Hiertoe neemt zij verschillende initiatieven. Het eerste komr kortweg neer op her bevriezen of korten van de budgetten van thuiszorgorganisaries ${ }^{23}$. Daarbij laat de overheid het aan de thuiszorgorganisaties zelf over hoe zij met minder budget dezelfde hoeveelheid of, gezien de toenemende vraag, zelfs meer zorg kunnen leveren. Men zou hier kunnen spreken van sturing via de geldkraan. Bij deze vorm van sturing is een belangrijke rol weggelegd voor het management van thuiszorgorganisaties. Zo kan het management 
een organisatie zodanig herstructureren dat een gunstigere verhouding tussen her aantal directe en indirecte zorguren tot stand komt of beslissen welke verhouding er in het personeelsbestand zal zijn tussen de hoger opgeleide verpleegkundigen van niveau vijf en de minder hoog opgeleiden van de niveaus drie en vier. Het management vertaalt budgetkortingen in concrete maatregelen.

Fusering is een ander, door de overheid gepropageerd instrument waarmee her management van thuiszorgorganisaties grotere doelmatigheid zou moeten bewerkstelligen. Een samengaan van kruiswerk en gezinsverzorging zou een besparing opleveren van 250 miljoen gulden op landelijk niveau ${ }^{24}$. Door grotere beheers-en financieringseenheden te creëren, zou het in de visie van de overheid mogelijk zijn de 'overhead' binnen deze organisaties terug te dringen en de kosten voor thuiszorg te beteugelen. Inmiddels zijn heel wat thuiszorginstellingen gefuseerd.

Het management van thuiszorgorganisaties vertaalt doelmatigheid niet alleen in organisatorische veranderingen, maar streeft ook naar aanpassingen in de directe zorgverlening. Juist deze maatregelen hebben gevolg voor de activiteiten van de professionele verzorgers en uireindelijk voor de inzet en de aard van de informele zorg. De maatregelen van het management van thuiszorgorganisaties, komen veelvuldig neer op een 'vertechnisering' van de zorg. De aanname hierbij is dat technologie de efficiëntie in de zorgverlening bevordert en patiënten minder afhankelijk maakt van verzorgers.

'Technologie vergroot de mogelijkheden van substitutie van intramurale zorg door thuiszorg; het kan de efficiëntie en de flexibiliteit van de thuiszorg vergroten en in veel gevallen maakt het de patiënt minder afhankelijk van de zorgverlener ${ }^{25}$.'

Het gaat daarbij op de eerste plaats om het streven naar de inzet van meer technische hulpmiddelen. Voorbeelden hiervan zijn het gebruik van een kousenaantrekker of het gebruik van een tillift. Dit zou de kosten in de primaire zorg drukken. Als een ziekenverzorgende een patiënt leerr een kousenaantrekker te gebruiken, hoeft ze die zorg immers zelf niet meer te verrichten en als de informele verzorger het gebruik van een tillift aanleert, hoeft de wijkverpleegkundige niet meer te komen om de patiënt uit bed te tillen. Een patiënt die problemen heeft mer douchen kan hiervoor drie maal per week hulp van een wijkverpleegkundige krijgen, maar een aanpassing in de badkamer kan soms een simpeler en goedkopere oplossing bieden. Op die manier zou techniek als substituut voor (professionele) verzorgers kunnen dienen ${ }^{26}$.

Om het gebruik van technicken te bevorderen zijn via het 'Stimuleringsprogramma Thuiszorgrechnologie" subsidies voor projecten met dit doel verstrekt ${ }^{27}$. Zo kreeg een project in Gorinchem subsidie. Het had tor doel intrave- 
neuze toediening van cytostatica aan patiënten thuis te bevorderen. In Breda subsidieerde de overheid een project dat informele verzorgers van demente ouderen via de personal compurer van kennis voorziet. De verwachting hierbij was dat informele verzorgers meer vertrouwen zouden krijgen in hun eigen kunnen en minder afhankelijk zouden zijn van professionals. Het programma omvatte dus onder meer een aantal substitutieprojecten, waarbij techniek diende om vervanging van ziekenhuiszorg door thuiszorg en van professionele zorg door informele zorg te stimuleren ${ }^{28}$.

Naast het gebruik van technische hulpmiddelen stimuleert het management van thuiszorgorganisaties het gebruik van beslissingsondersteunende technieken zoals standaard intake-formulieren en andere protocollen. Hierdoor zou de zorgindicatie objectiever zijn en efficiënter verlopen ${ }^{29}$. Interessant is dat de huidige formulieren die intakers of indicatieadviseurs gebruiken, expliciet voorschrijven rekening te houden met de aanwezige informele zorg ${ }^{30}$. Het is daardoor gebruikelijk dat de 'intaker' bij toewijzing van professionele zorg meestal een eenmalige inschatring maakt van de hoeveelheid zorg die informele verzorgers kunnen bieden ${ }^{31}$. Zo is de verschuiving van professionele naar informele zorg in beslissingsondersteunende technieken vastgelegd.

\begin{tabular}{|c|c|c|c|c|}
\hline \multicolumn{5}{|c|}{ Beschillbare mantelzorg binnen de leefeenheid } \\
\hline \multirow[t]{7}{*}{ Relatie } & Neam & Activiteit & Frequentie & max. Belast \\
\hline & & & & 0 \\
\hline & & & & 0 \\
\hline & & & & 0 \\
\hline & & & & 0 \\
\hline & & & & 0 \\
\hline & & & & 0 \\
\hline \multicolumn{5}{|c|}{ Beschikbare mantelzorg buriten de leeteenlveid } \\
\hline \multirow[t]{7}{*}{ Relatie } & Nam & Activiteit & Frequentie & max. Belant \\
\hline & & & & a \\
\hline & & & & $\mathbf{9}$ \\
\hline & & & & 0 \\
\hline & & & & 0 \\
\hline & & & & 0 \\
\hline & & & & 0 \\
\hline \multicolumn{5}{|c|}{ Vrage and de mantelzorgvertener: } \\
\hline \multicolumn{5}{|c|}{ Heelt u behoefte aan ondersteuning en waarvit zou naar uw mening de ondersteuning kunnen bestaan? } \\
\hline & & & & \\
\hline & & & & \\
\hline & & & & \\
\hline
\end{tabular}

Figuur x: Voorbeeld deel standaard intake-formulier rıo Zuidelijk Zuid-Limburg. 
GIRST, een erkend indicatiesysteem, gaat bijvoorbeeld uit van het 'zelfzorgvermogen' van de patiënt. De indicatieadviseur of intaker graat bij de patiënt na welke 'zelfzorg-tekorten' zich voordoen ${ }^{32}$. Op de standaard-formulieren is steevast ruimte waar (mogelijke) compensatie (van zelfzorg) door huisgenoten komt te staan. Afhankelijk van de aanwezige informele zorg zet men dan professionele zorg in. Op die manier is de 'plicht' tot het geven van informele zorg in het indicatiesysteem verankerd en bepaalt de beschikbaarheid van informele zorg het gebruik van professionele zorg. Aan het geven van informele zorg valt nog moeilijk te ontkomen".

Samengevat, bevordert de overheid de informele zorg aan zieke mensen niet direct. Via beleidsmaatregelen die erop gericht zijn de doelmatigheid van de professionele zorgverlening vanuit thuiszorgorganisaties te vergroten, wil ze haar doel via indirecte weg bereiken. Thuiszorgorganisaties vertalen de opdracht tot doelmatig werken in 'vertechnisering' van de zorg. Deze maatregelen werken uiteraard door in de activiteiten van de professionele verzorgers en hebben uiteindelijk ook gevolgen voor de informele zorg. Zo kan de inzet van technische hulpmiddelen substitutie van professionele zorg naar informele zorg bevorderen en is in protocollen vastgelegd dat professionele zorg pas aan de orde is als informele zorg niet toereikend blijkt. Op die manier lukt het de overheid, bij wijze van spreken, de huiskamers waarin zieken verblijven te betreden en invloed uit te oefenen op het zorggedrag van burgers.

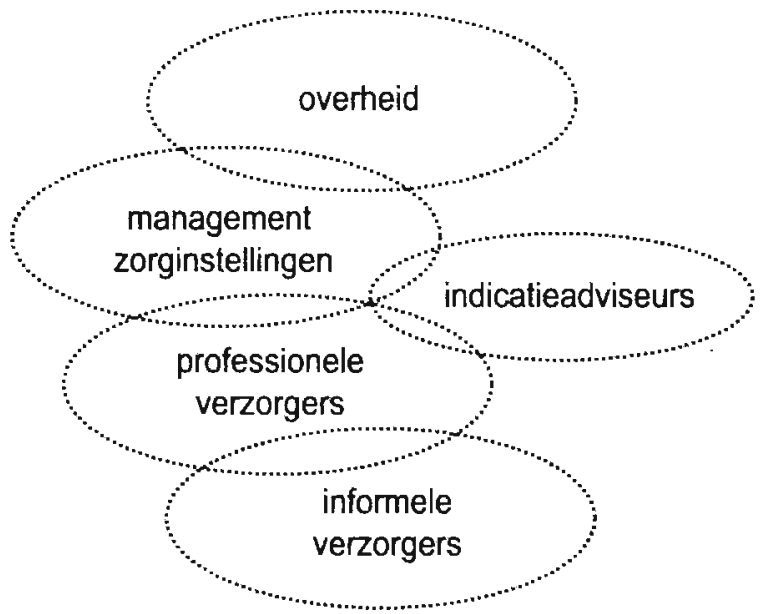

Figuur 2: Vereenvoudigde weergave relatie overheid/informele verzorgers ${ }^{34}$. 


\section{Argumenten bij stimulering van informele zorg}

In de vorige paragraaf is beschreven dat de overheid een groter beroep wil doen op informele zorgverleners. Ze zet hierbij een aantal actoren in die (finincicel) van haar afhankelijk zijn. Her management van thuiszorgorganisacies, indicatieadviseurs en professionele verzorgenden geven het beleid vorm. Inmiddels is binnen thuiszorgorganisaries de algenene opinie dat professionele zorg pas ingezet mag worden als zorg van verwanten niet (meer) mugelijk is. Op welke gronden propageert de overheid informele zorg? Op grond van welke overwegingen en argumenten is uitbreiding van informele zorg wenselijk?

De overheid geeft drie argumenten voor stimulering van informele zorg. Het eerste is van financieel-economische aard. De bevordering van informele zorg valt niet los te zien van het streven van de overheid naar kostenbesparing in de gezondheidszorg. Kostenbeheersing staat sedert eind jaren zeventig op de politicke agenda en heeft tor dusver nog niets aan actualiteit ingeboet. Een belangrijke aanname hicrbij is dat her aantal ouderen zowel absoluut als relatief zal groeien. Als gevolg van de vergrijzing en de daarmee gepaard gaande veranderingen in het morbiditeitspatroon zal, zo verwachten beleidsmakers, de vraag naar professionele (thuis)zorg toenemen ${ }^{35}$. In het verlengde hiervan zal de aard van de hulp veranderen van acuut naar chronisch en van levensbedreigende ziekren naar zickten die gepaard gaan met relatief veel zorgafhankelijkheid. Naast diagnostiek en therapie zullen vooral verzorgende handelingen in aantal en omvang tocnemen. 'Cure' zal in toenemende mate aangevuld moeten worden met 'care' " ".

De overheid gaat ervan uit dat de beschikbare middelen bij ongewijzigd beleid, mede vanwege de vergrijzing, niet langer toercikend zijn. Ze anticipeert hierop ${ }^{37}$. Een groot effect verwacht ze van maatregelen die dure opnames door goedkopere zorg thuis vervangen en van maatregelen waarbij informele zorg de professionele thuiszorg vervangt. Dergelijke substituties, ook wel extramuralisering van zorg genoemd, zouden het mogelijk maken kostenbesparing op de zorgverlening door te voeren.

'Gezien de nog steeds groeiende vraag naar zorg en de noodzakelijkerwijs bepcrkte budgetten is extramuralisering, mits de kwaliteit van zorg thuis gegarandecrd is, een voor de hand liggende keus ${ }^{28}$.'

Een tweede argument om informele zorg te stimuleren is meer ideologisch van aard. Volgens de overheid geven burgers de voorkeur aan informele zorg boven professionele zorg. De meeste burgers, zo stellen beleidsmakers, zouden graag zo lang mogelijk zelfstandig blijven en liever niet afhankelijk zijn van professionele zorgverleners. Zorg thuis en door naasten zal voor hen leiden tot meer zelfstandig- 
heid en autonomie ${ }^{39}$. Daarom zullen burgers, ondanks ziekte of handicap, er de voorkeur aan geven thuis te blijven, in hun vertrouwde omgeving met vertrouwde mensen om zich heen ${ }^{40}$.

'Het beleid en de praktijk zijn gericht op extramuralisering, gebaseerd op voorkeuren van mensen zelf, (... $)^{+\mu}$.

Een derde argument luidt dat informele zorg op verschillende manieren de kwaliteit van de zorgverlening verhoogt. Zo verwijzen beleidsmakers bijvoorbeeld naar onderzoek waaruit blijkt dat herstel thuis na bijvoorbeeld een operatie voorspoediger verloopt dan in een ziekenhuis ${ }^{4^{2}}$. Ook stellen ze dat informele verzorgers ertoe bijdragen dat patiënten niet vereenzamen. Ze geven meer 'humane' zorg dan professionele zorgverleners ${ }^{43}$. Dit in tegenstelling tot een verblijf in een instelling. Dat leidt tot hospitalisarie, een verlies van eigen verantwoordelijkheid. Een opname betekent bijvoorbeeld dat de patiëntenrol makkelijk boven andere rollen gaat domineren. Het gevaar dreigt dat een patiënt niet meer als onafhankelijk individu wordt beschouwd, maar als afhankelijke van medici, verzorgenden en techniek. Een patiënt die thuis blijft en door naasten wordt verzorgd, zal minder afgesneden zijin van de dagelijkse gang van zaken dan iemand die opgenomen is.

'Het actief betrekken van de thuisomgeving bij de zorg aan de hulpvrager kan namelijk voorkomen dat de laarste in de beleving van zijn/haar ziek zijn of handicap geïsoleerd raakt. De zieke of gehandicapte blijft opgenomen in zijn/haar eigen netwerk. Thuiszorg draagt ertoe bij dar het ziekteproces of de handicap verbonden blijft met andere belangrijke zaken in het leven van mensen, zoals bijwoorbeeld her gezin, de sociale omgeving, de woonsituatie, het werk ${ }^{+4}$.'

De dric bovenstaande redenen versterkt de overheid, tot slot, met een (vierde) bewering. De informele zorg zou tor in de jaren tachtig miskend zijn. Professionals van voor die tijd zouden te gemakkelijk taken van informele verzorgers over hebben genomen en bovendien zou er te weinig aandacht zijn geweest voor het feit dat de aanwezigheid van hulp in de directe omgeving van patiënten zeer bepalend is voor de vraag naar professionele hulp "s. In onderstaand citaat komen deze argumenten samen:

'...dat in een tijd van sterke ontwikkeling van de professionele zorg door alle betrokkenen te weinig aandacht is besteed aan de grote kwantitatieve en kwalitatieve betekenis van de informele hulpverlening. Daardoor zijn te gemakkelijk raken uit dit informele circuir door professionele hulpverleners overgenomen ${ }^{46}$.'

Samenvattend stellen beleidsmakers dat het goed voor een zieke is een directe relatie met informele verzorgers te hebben. Letterlijk: 
'Mensen uit de directe omgeving van individuen die zorg nodig hebben zijn belangrijk voor de kwaliteit van de thuiszorg ${ }^{47}$.'

Dat informele verzorgers bijdragen aan een goede kwaliteit van zorg is volgens beleidsmakers te danken aan het feit dat ze de genezing bevorderen, helpen voorkomen dat de hulpvrager in de beleving van zijn/haar ziek zijn of handicap geïsoleerd raakt ${ }^{48}$. Daarbij zou informele zorg continuteit in de zorgverlening garanderen $^{49}$. Informele zorg zou dus garant staan voor kwalitatief hoogwaardige zorg.

Kijken we naar bovengenoemde argumentatie van de overheid, dan vallen de argumenten grofweg in rwee categorieën uiteen. Enerzijds stelt de overheid dat informele zorg goede zorg is. Hiermee spreekt ze de burger aan. Anderzijds stelt ze dat inzet van (meer) informele zorg kosten van de gezondheidszorg reduceert $\%$. Dit is voor de (kosten) beheersing van het zorgsysteem van belang. Het is niet zo verwonderlijk dat op deze 'dubbele moraal' kritiek is gekomen. Zo zouden kwaliteits- en economische argumenten wellicht op papier samen gaan, maar elkaar in de praktijk bijten ${ }^{\text {si }}$. Informele zorg, gedefinieerd als voorwaarde tot onafhankelijkheid, verhoudt zich moeizaam tor kostenbesparing. Achter de verschillende argumenten gaan uiteenlopende belangen schuil. Zet de overheid in haar argumentatie dat patiënten thuis onafhankelijk zijn de patiënt voorop, in het economische argument staat het gezondheidszorgsysteem op de eerste plaats. Kortom: een eerste blik op de argumentatie van de overheid voor informele zorg illustreert cen paradoxale inzet van dit beleid. Wat versta ik in deze studie precies onder beleid?

\section{De constructie van werkelijkheden in beleid}

Beleid is op te vatten als een activiteit, een doelbewust streven te interveniëren in de sociale werkelijkheid. Beleid is ook te beschouwen als handelingsproces, maar dit is ondermeer vanwege het communicatieve karakter van het informele-zorgbeleid niet de manier waarop ik beleid analyseer. In de vorige paragraaf beschreef ik enkele argumenten die de overheid voor het stimuleren van informele zorg gebruikt. Deze argumenten zijn ontleend aan teksten. Beleid wordt in dit onderzoek geanalyseerd als een tekst en beschouwd als een geheel van ideeën, een op schrift gesteld gedachtengoed dat gekaft de (beleids)instellingen in het land rondreist. Het is te beschouwen als een poging de wereld te ordenen door middel van taal.

Volgens de constructivistische wetenschapsopvarting, die ik in dit proefschrift volg, verwijst taal niet naar de werkelijkheid, maar creëert ze er één ${ }^{\text {}}$. Alle actoren die met een bepaald beleid in aanraking komen, zoals in dit geval managers van 
thuiszorgorganisaties, professioneel verzorgenden en burgers krijgen dus een en niet dé werkelijkheid voorgehouden. Zo wordt in het zorgbeleid bijvoorbeeld verteld waaruit een zorgsysteem wel en niet bestaat, wie in zo'n systeem een plaars heeft, wie niet, hoe actoren zich daar gedragen en wat bijvoorbeeld het verschil is tussen het gedrag van mannen en vrouwen. Het vertelt ook wat goede en foute zorg is, wat (on)juist en (on)rechtvaardig is, of waar het (on)aangenaam is zorg te ontvangen. Tot slot vertelt het de betrokkenen wat in zorgsettings (on)mogelijk is. Kortom: door middel van de taal worden feiten, waarden en handelingsmogelijkheden geconstrueerd en met elkaar in een verband gebracht. Beleidsmakers creëren dus bepaalde werkelijkheidsdefinities van (informele) zorg en geven deze door.

Dit onderzoek laat zien welke specifieke werkelijkheden beleidsmakers, al dan nier bewust, in hun nota's over het informele-zorgbeleid creëren. Doordat zij een werkelijkheid verwoorden en een andere niet, raakt die andere buiten ons gezichtsveld. Soms lijkt het dan alsof beleidsmakers de betrokkenen bij het beleid 'ware' kennis, problemen en oplossingen aanreiken, maar deze problemen en oplossingen zijn te beschouwen als een manier om de werkelijkheid te beschrijven. Ze worden met en in dat beleid waar gemaakt". Natuurlijk weten beleidsmakers dat (ook). Ze gebruiken teksten om elkaar en anderen te overtuigen van hun waarneming van 'de werkelijkheid' en proberen hun visie van het hoe en waarom aan anderen op te leggen door inzet van de taal ${ }^{54}$. Dit maakt het formuleren van beleid geenszins vrijblijvend, het is een consciëntieuze bezigheid.

Deze studie is primair bedoeld om te laten zien hoe teksten bestaande waarden of ideeën bevestigen en die als "waarheid' presenteren ". Beleid is dan evenals iedere andere vertelling (verhaal, sprookje of gedicht) op haar impliciete veronderstellingen, (gestolde) waarden of conventies te bestuderen. Daarbij is het de vraag welke conventies beleidsmakers bestendigen en welke ze negeren.

Voor een dergelijke beleidsanalyse is geen uitgekristalliseerde merhode voorhanden. Belangrijk bij onderzoek nar conventies in beleid is dat de onderzoeker de aannames expliciteert en bovendien zegt op welke conventies de studie zich richt. Zijn deze bijvoorbeeld verbonden met een Noord-Europese cultuur? Zijn ze verbonden met hetroseksuele uitgangspunten of met gangbare man/vrouw-beelden; ook wel her androcentrisch perspectief genoemd ${ }^{56}$ ? Laar ik met de aannames beginnen.

De eerste aanname in deze studie luidt dat beleid beschouwd wordt als drager en producent van (gestolde) waarden van een specifieke cultuur. Beleid is in deze opvatting een cultuur en plaatsgebonden 'vertelling'. Het is een bepaalde voorstelling van een situatic. Daarmee is niet gezegd dat elke voorstelling evenveel kans maakt in het beleid terecht te komen. Sommige zijn 'machtiger' dan andere, die 
macht hangt samen met de macht van diegenen die ze uitdraagt en verandert in de rijd.

Beleid behoort, deze gedachrengang volgend, niet alleen toe aan actoren die bij het ontwerpen of het bepalen van een bepaald beleid betrokken zijn. Want culturele waarden of conventies komen niet alleen in de argumentaties van de beleidsmakers voor. Daarom achten onderzoekers in de constructivistische traditie 'de context' van het beleid van bijzonder belang. Volgens deze opvarting maken dus niet alleen beleidsmakers beleid, maar alle bij het informele zorgbeleid betrokken actoren. $\mathrm{Zij}$ worden dan beschouwd als partijen die actief bij de constructie van beleid betrokken zijn en niet louter als (plichtsgetrouwe of passieve) uirvoerders ${ }^{7}$.

De laatste aanname in een constructivistische opvatting van beleid luidt dat het niet eenvoudig is conventies in de beleidsargumentaries te vinden. Want eigenlijk gaat het erom systematisch vragen te stellen over alternatieve waarden of conventies die de beleidsmaker had kunnen gebruiken ${ }^{6}$. Aangezien ook de beleidsanalist deel uitmaakt van de onderzochte cultuur blijkt dat geen eenvoudige opgave. De onderzoeker staat in die zin nooit 'buiten' of 'boven' het beleid, want ook hij of zij schrijft een tekst. De beleidsmakers en de beleidsanalist zijn deel van de onderzochte (beleids)cultuur.

Samengevat ga ik er vanuit dar beleid een vertelling is die een wereld vormt, dat beleidsmakers bij het vormen van die wereld, wellicht onbedoeld, culturele waarden vastleggen, bestendigen en voortzetten $"$. Tor slot betekent dit dat bij deze analyse van beleid aandacht is voor 'de context' waarin het beleid tot stand komt.

Voordat ik de onderzoeksvraag verder toespits en de methode van onderzock beschrijf, bespreek ik in de volgende paragraaf de theoretische concepten te weten: 'intertekstualiteit', 'representatie' en 'gender' waarop dit onderzoek stoelt ${ }^{60}$. Dan wordt ook duidelijk op welke conventies de studie zich richt.

\section{Intertekstualiteit, representatie en gender}

Dit onderzoek staat in een constructivistische traditie. Vanwege het communicatieve karakter van het informele- zorgbeleid wordt beleid in deze studie opgevat als tekst. Ik ben geïnteresseerd in de vraag welke specifieke werkelijkheden beleidsmakers in hun beleidsteksten over informele zorg creëren. Her doel van deze studie is om fundamentele conventies die niet expliciet in beleid worden vermeld in kaart te brengen. Een manier om die conventies op het spoor te komen is door systematisch de vraag te stellen naar alternatieve veronderstellingen waarop de beleidsmaker zich had kunnen baseren ${ }^{64}$. 
Binnen de beleidswerenschap is 'de beleidsanalyse' een veel gebruikre techniek om verborgen veronderstellingen op te sporen. $\mathrm{Bij}$ zo'n analyse staat het zoeken naar de betekenis van die tekst op de voorgrond ${ }^{62}$. In de constructivistische traditie gaat men er echter vanuit dat er niet één betekenis aan een tekst te geven is, maar vele. Het zoeken naar dé betekenis wordt dan ook als essentialistisch ter zijde geschoven. In de constructivistische beleidsanalyse spreekt men dan ook liever over vertoog-, of discoursanalyse ${ }^{63}$. Hierbij vormt de context een belangrijk gegeven.

Als uitgangspunt geldt dat de betekenis van een tekst tot stand komt in en door de relatie met andere teksten; door de relarie mer dat wat ook of al betekenis heeft ${ }^{64}$. Iedere tekst, dus ook beleid, is geconstrueerd met behulp van oude elementen, die in hun nieuwe context een nieuwe functie en nieuwe (bij)betekenissen krijgen. In een tekst ligt dus altijd een verwijzing naar een oudere, andere rekst besloten. Anders gezegd: de betekenis van een tekst wordt bij een vertooganalyse afgeleid uit een analyse van de context. Dat betekent dat men iedere tekst opvat als een 'inter-tekst' ofwel een kruispunt van teksten, een deel van een groter vertoog. Dit kruispunt van teksten noemt men ook wel intertekstualiteit.

In intertekstualiteit zijn drie vormen te onderscheiden ${ }^{65}$. Zo is de verwijzing naar een andere tekst evident als deze direct en duidelijk naar een bron verwijst. Dit gebeurt bijvoorbeeld als het beleid over informele zorg verwijst naar onderzoek op dat gebied. De intertekst beleid - onderzoek is in dat geval zonneklaar.

Een duidelijke verwijzing in de beleidstekst naar een andere tekst is echter geen noodzaak om toch te spreken van intertekstualiteit. Zo is 'het genre' of 'het soort tekst' eveneens te beschouwen als intertekst. Een sprookje bijvoorbeeld herkent de lezer aan de beginzin. 'Er was eens..., en aan een moraal tor slot. Een gedicht herkennen we aan de specifieke vormgeving, het woordgebruik, de klankresonanties en een roman aan zijn opbouw, betooglijn en plot. Het genre zegt dus ook iets over de rekst en hoe deze zich tot andere teksten verhoudt. Genres leveren zowel formele als inhoudelijke modellen van wat gezegd kan worden en hoe dat kan. Doordat teksten gemodelleerd zijn naar bestaande en bekende genres ontstaan condities van herkenbaarheid en verstaanbaarheid. De lezer van dit proefschrift zal bijvoorbeeld het citaat waar dit hoofdstuk mee begint - 'Ieder beroep op eerstelijnsvoorzieningen zal steeds worden afgewogen tegen de mogelijkheden van de hulpvragenden om zelf door middel van onderlinge hulpverlening een oplossing voor de problemen re vinden.' - snel als beleidsgenre herkennen, want dergelijk taalgebruik staat in een traditie waarin formele en plechtstatige bewoordingen gebruikelijk zijn.

De derde vorm van intertekstualiteit is wat diffuser. Het gaat hierbij om moeilijk te traceren conventies ofwel cultureel ingeburgerde wijzen van zien en spreken, 
waarvan de bronnen allang verloren zijn. Deze worden ook wel 'een verstarde code van representatie' genoemd of 'een conglomeraat van geaccepteerde, steeds weer terugkerende motieven en wijzen van representatie rond een thema, dat zich continu organiseert in nieuwe culturele teksten ${ }^{66}$. . De gedachte hierbij is dat onze samenleving in haar geschiedenis een specifieke verzameling waarden en normen heeft voortgebracht waardoor wij worden beïnvloed, en die de basis vormt voor het arsenaal aan morele waarden dat wij zelf gedurende ons leven ontwikkelen. Een intertekstuele analyse hoeft er dus niet op gericht te zijn her unieke van een tekst te achterhalen, maar is zeker zo interessant als ze toont hoe de tekst bestaande 'waarden en normen' of 'conventies' reproduceert ${ }^{67}$. Juist op deze derde vorm van intertekstualiteit, reproductie richt dit onderzoek zich.

Binnen vrouwenstudies is het concept gender leidend bij het opsporen van conventies. Dit verwijst naar mensen, naar mannen en vrouwen en in deze studie vooral naar waarden die daarmee verbonden zijn ${ }^{68}$.

$\begin{array}{ll}\text { 'mannelijke waarden' } & \text { 'vrouwelijke waarden' } \\ \text { man } & \text { vrouw } \\ \text { patient } & \text { verzorger } \\ \text { arbeid } & \text { zwak } \\ \text { sterk } & \text { emotie/intuitie } \\ \text { ratio } & \text { afhankelijkheid } \\ \text { autonomie } & \text { passief/inactief } \\ \text { actief } & \text { doen } \\ \text { denken } & \text { privé } \\ \text { openbaar } & \text { ambigu } \\ \text { eenduidig } & \text { vrijwillig } \\ \text { betaald } & \text { instabiel } \\ \text { stabiel } & \text { onmacht } \\ \text { macht } & \text { onzekerheid/twijfel } \\ \text { doortastendheid } & \text { praktijk } \\ \text { wetenschap } & \text { meningen } \\ \text { feiten } & \text { amateuristisch } \\ \text { professioneel } & \text { creatief } \\ \text { planmatig } & \text { relaties } \\ \text { regels } & \\ \text { enzovoorts.... } & \end{array}$

Het ordenen van de wereld in 'mannelijke waarden' en 'vrouwelijke' beschouwt men binnen vrouwenstudies echter niet als een neutrale of 'onschuldige' activiteit. 
Door de wereld steeds in 'mannelijke' en of 'vrouwelijke' dichotome patronen te beschrijven, zouden deze patronen worden waar gemaakr. Bovenal bevestigen ze de hiërarchie tussen seksen. Kortom: gender is op te vatten als een maatschappelijk en symbolisch ordeningsprincipe, waarbij de orde die ontstaat tevens een hiërarchische is ${ }^{69}$. Voor deze beleidsanalyse betekent dit dat een gendergeladen tekst vanzelfsprekendheden bevat die erop neerkomen dat her mannelijke steeds het algemene, het centrale en het hoger gewaardeerde is, terwijl het vrouwelijke het uitzonderlijke, het marginale en het minder gewaardeerde vormt ${ }^{70}$.

Om dergelijke geseksueerde conventies van beleidspraktijken te duiden, gebruiken vertooganalytici ook wel het aan intertekstualiteit en gender verwante concept 'gender-subtekst' ${ }^{7}$. Dat wordt gedefinieerd als sub- of neventekst; conventies, die 'verweven zitten' in een oorspronkelijke tekst en betrekking hebben op de verzwegen 'ondertiteling' van een schijnbaar genderneutrale praktijk. Het zijn 'verborgen waarden die de gangbare betekenissen van mannelijkheid en vrouwelijkheid (re)produceren en in een hiërarchische verhouding tot elkaar plaatsen ${ }^{72}$.' De gender-subtekst is een analytisch concept dat het zoeklicht richt op verborgen betekenissen en conventies van mannelijkheid en vrouwelijkheid in beleid?3. Oftewel: een sekse-specifieke set van waarden of conventies in een beleidstekst. Want, zo luidt het uitgangspunt binnen vrouwenstudies: 'Sekse is als een kracht, die elke tekst van binnenuit bestuurt. Het is een conventioneel systeem van regels dat de representatie organiseert. Die geseksueerde organisatie van representatie lijkt zo 'vanzelfsprekend' dat zij niet langer als conventie wordt gezien. Dat verklaart dat sekse zo vaak als 'natuurlijk' wordt beschouwd en daarmee in de analyse van cultuuruitingen over het hoofd wordt gezien ${ }^{74}$.'

Uit onderzoek naar gender-subteksten of conventies is al gebleken dat beleidsteksten van de overheid, weliswaar onbedoeld en vaak verborgen, vooroordelen over mannen en vrouwen en over hun vermeende rol en positie in de samenleving bevatten. 'Inactieven' als benaming voor werklozen is zo'n voorbeeld. Deze term is vreemd als het om een huisvrouw gaat die naast de opvoeding van kinderen, het wijkblad redigeert, voorlees-en oversteekmoeder is en tal van andere klussen klaart 7 . Het gebruik van de term 'inactief' hangt wellicht samen met een andere (beleids)term 'werknemer'; eveneens te beschouwen als een gender-conventie. In overheidsteksten is deze werknemer meer geordend naar een mannelijk dan naar een vrouwelijk model. Werknemers, vaak vrouwen, die hun betaalde arbeid anders indelen dan de 36-urige norm, worden nog vaak als minder of lastig bestempeld en daardoor gemarginaliseerd ${ }^{76}$. En ook onderzoek naar gender-subteksten in beleidsinstrumenten die toch bedoeld zijn om maatschappelijke (gender) ongelijkheden te doorbreken, toont aan dat deze bij nader inzien weinig veranderen ${ }^{7}$. Zo bekrachrigt het functiewaarderingssysteem, ooit ingevoerd om mensen met een 
gelijke funcrie gelijk te belonen, de (scheve) verhoudingen tussen de seksen. Want, zo luidt de conclusie van dit onderzoek, het werk van een. parkeerwachter beloont men hoger dan dat van een kleuterleidster, dat van een kleuterleidster lager dan dat van een dierenverzorger, het werk van een verpleegkundige lager dan dat van een politieagent en dat van een vroedvrouw lager dan dat van een hotelbediende. Het vermoeden bestaat dat het beleid gericht op de functiewaardering de historische onderwaardering van beroepen en functies die vooral vrouwen uitvoeren, voortzet. Beleidsteksten en instrumenten kunnen dus stereotiepe beelden en vooroordelen over de plaats van mannen en vrouwen en over de waarde van 'mannelijkheid' en 'vrouwelijkheid' doorgeven, zonder dat beleidsmakers dit letterlijk of heel bewust formuleren.

\section{Gender en het informele zorgbeleid}

Er zijn drie redenen waarom er bij juist bij deze analyse van het informelezorgbeleid aandacht is voor gender-conventies. Op de eerste plaats richt het informele zorgbeleid zich hoofdzakelijk tot vrouwen. Informele verzorgers zijn voor het merendeel vrouwen. In Nederland bieden drie maal zoveel vrouwen $(76 \%)$ als mannen $(24 \%)$ informele zorg $^{75}$. Het zijn vooral vrouwen van middelbare leefrijd ook wel 'the sandwich generation' genoemd, vrouwelijke partners, dochters en schoondochters die zorg verlenen ". Hoewel bijvoorbeeld als gevolg van verschuivingen in rolpatronen tussen mannen en vrouwen of de rol van de buddy's bij de ondersteuning van Hrv-geïnfecteerden, sinds kort ook het aandeel van mannen in de zorg toeneemt, steekt het nog steeds mager af tegen dat van vrouwen ${ }^{\text {so }}$. De in het beleid gebruikte terminologie zoals stimulering van 'informele zorg', 'het zorgnetwerk' of 'de familiezorg' verhullen dat het gaat om vrouwenwerk.

Beleid gerichr op informele zorg is echter niet alleen vanwege de kwantitatieve inbreng van vrouwen sekse-specifiek beleid. Studies over zorg laten evenzeer zien, dat de betekenis van zorg sterk samenhangt met de betekenis van vrouwelijkheid ${ }^{8}$. 'Zorgen voor' betekent direct contact met diegene voor wie men zorgt. Er is sprake van lichamelijke arbeid, intimiteit en wederzijdse afhankelijkheid. Dit vraagt om een oplettende geest, verantwoordelijkheid ten opzichte van de verzorgde, bekwaamheid in het verzorgen en om een kwetsbare opstelling van de verzorgende. De aan zorg gekoppelde eigenschappen en waarden worden in ons maatschappelijk debat eerder geassocieerd met vrouwelijkheid dan mannelijkheid $^{82}$.

Tot slot is informele zorg in een private omgeving gelokaliseerd. Zorg beschouwt men meestal als een activiteit van mens tot mens, en niet als activiteiten van 
organisaries of landen ${ }^{83}$. Volgens historici hebben vanaf de achrriende eeuw met de scheiding van de publieke en private sfeer vrouwen een bestemming binnen het private gekregen en belichamen sindsdien het zorgzame ${ }^{84}$. Zorg, informele zorg, wordt dus om meerdere reden gekoppeld aan feminiteit. De kwantitatieve inbreng van vrouwen, de aard van de werkzaamheden en de plaats waar deze worden uitgevoerd brengen een niet-natuurlijke maar cultureel gebonden koppeling tussen zorg, vrouwen en vrouwelijkheid tot stand.

Hoezeer het gender-concept mij ook verder helpt om specifieke conventies in het informele-zorgbeleid op te sporen, er zit ook een gevaar aan het gebruik. Ten eerste is de gender-dichotomie weinig genuanceerd. Wat 'mannelijk' en 'vrouwelijk' is lijkt op deze manier vast te staan, terwijl dat juist varieert van rijd cor tijd en van (sub) cultuur ror (sub)cultuur. Op de rweede plaats bestaat her gevaar dat het gebruik van deze dichotome tweedeling stereotype beelden bevestigt en zo de machtsorde reproduceert, terwij] het onderzoek vanuit het gender-concept deze stereotypen zou moeten relativeren. Ik ben me bewust van deze valkuilen, maar kan er moeilijk omheen. Want om inzicht te geven hoe gender ordent, moet ik laten zien dat en hoe beleidsmakers van deze tweedeling gebruik maken, om vervolgens voor de (onbedoelde) hiërarchie die hiermee ontstaat alternatieven aan te dragen. Pas dan kan ik aantonen dat in het informele-zorgbeleid waarden die verbonden zijn met mannelijkheid (regels, arbeid, ratio en betaald) in onze cultuur over het algemeen genomen een hogere status en meer handelingsmogelijkheden geven dan waarden die verbonden zijn met vrouwelijkheid (relaties, zorg, emotie en vrijwillig).

Samengevar: hiërarchieën waarbij 'mannelijke waarden' boven vrouwelijke staan zijn geen 'natuurlijk' gegeven, maar worden steeds geconstrueerd. Deze constructie vindt onder andere plaats in beleid. Onderzoek vanuir vrouwenstudies heeft onder meer als doel die hiërarchie aan te tonen, te relativeren en als 'onnatuurlijk' te verklaren. Dit proefschrift is het verslag van een analyse van het informele- zorgbeleid gebaseerd op deze uitgangspunten. Ik neem aan dat conventies in beleid inzicht geven in de waardengebondenheid van beleid en richt me vanwege de aard van het informele- zorgbeleid in het bijzonder op conventies over gender.

De probleemstelling die hierbij past luidt: Welke (gender)conventies spelen een rol in het informele-zorgbeleid? Deze vraag betekent dat ik er vanuit ga dat het beleid over informele zorg niet gender-neutraal is. Dit beleid bevat en bevestigt (onbedoeld) veronderstellingen over mannelijkheid en vrouwelijkheid. De analyse is echrer niet bedoeld om alle teksten van beleidsmakers over informele zorg te analyseren, noch alle gender-conventies te beschrijven. Ze toont hoe gender- 
conventies in her informele-zorgbeleid verweven zijn en gaat in op de betekenis hiervan voor verzorgers.

\section{Methode van onderzoek}

Hoe heb ik, met inachtneming van de theoretische concepten 'intertekstualiteit', 'representatie' en 'gender' en bovenstaande doelstelling antwoord gegeven op de probleemstelling? Oftewel: hoe heb ik het onderzoek aangepakt? Op de eerste plaars heb ik zogenaamde 'tegenverhalen' of 'counterstories' gebruikt bij de analyse van conventies in beleid. Dit zijn teksten uit andere 'werelden' dan het beleid, die echter wel hetzelfde onderwerp behandelen ${ }^{85}$. Concreet heb ik de beleidsreksten over informele zorg steeds vergeleken met teksten van wetenschappers of verzorgers zelf. Beleidsmakers gebruiken immers wetenschappelijke teksten om hun beleid te staven. Daarbij willen ze problemen van verzorgers oplossen. Ze trachten in ieder geval antwoord te geven op door verzorgers aangereikte kwesties en bij hen aan te sluiten. Wetenschappers en verzorgers zijn dus belangrijke peilers voor dit beleid.

De gelijktijdige analyse van beleidsteksten en wetenschappelijke teksten of teksten van verzorgers laat overeenkomsten, maar vooral verschillen in conventies zien. Het geeft enerzijds inzicht in de overeenkomsten, verwevenheid en culturele inbedding van het beleidsvertoog met andere vertogen (intertekstualiteit en representatie). Het zorgt anderzijds voor afstand, verbazing en reflectie en biedt de kans afstand te nemen van de beleidstekst ofwel het verschil in gebruikte conventies met andere teksten te duiden (alternatieve conventies). Met andere woorden: door een vergelijking van een beleidstekst met een andere tekst kan dat wat de beleidstekst als vanzelfsprekend reproduceert, beter in het zicht komen. Het laat regelijk datgene zien wat het beleid uitsluit of niet vertelt.

De concepten intertekstualiteit en representatie geven richting aan de manier waarop ik de beleidsteksten heb geanalyseerd, het concept gender geeft een kleuring en afbakening van hetgeen ik in de teksten zoek. Zoals gezegd kan een onderzoeker die het constructivisme serieus neemt de betekenis van een tekst of verborgen conventies in een tekst niet achterhalen door zich te verplaatsen in de positie van de auteur. De onderzoeker kan zich wel opstellen als een 'archeoloog' die de dragende elementen van een tekst opspeurt en inzichtelijk maakt ${ }^{86}$.

De dragende elementen van een tekst zijn de woorden. Daarom heb ik in de beleidsteksten eerst gezocht naar veelvoorkomende woorden. Woorden die bij elkaar hoorden heb ik vervolgens geclusterd tot thema's. Zo kwam ik onder andere tot de thema's 'verzorger', 'thuis' en 'kennis'. Deze thema's zijn verder 
ontrafeld met inzichten uit de literatuur over gender. Dat wil zeggen dat ik binnen deze thema's lette op voorkomende dichotomieën. Zo heb ik bij het thema 'verzorger' ondermeer onderscheid gemaakt in man-vrouw, verzorger-verzorgster, helper-geholpene en kracht en zwakte. Bij het thema 'thuis' onderscheidde ik bijvoorbeeld publiek-privaat, ziekenhuis-thuis, patiënt-verzorger en autonomieafhankelijkheid. Bij 'kennis' heb ik onder andere onderscheid gemaakt in professional-leek, rationeel- intuïtief, systematisch-associatief, onderzoekend-aldoende, objectief-subjectief. Deze in het beleid gevonden thema's, uitgesplitst naar dichotomieën vergeleek ik steeds met soortgelijke dichotomieën in de wetenschap of verhalen van verzorgers. Waarin vond ik overeenkomst en waar zag ik verschil? Zoals gebruikelijk in kwalitatief onderzoek was dit een cyclisch proces. Uitgaande van het beleid keek ik naar dichotomieën in de wetenschap of in de verhalen, via de wetenschap en de verhalen ging ik weer terug naar dichotomieën in het beleid.

\section{Data}

De vrang naar gender-convelties in het informele-zorgbeleid en de gekozen methode van onderzoek vragen om drie soorten data te weten: beleidsteksten, wetenschappelijke teksten en teksten van verzorgers over informele zorg. In deze paragraaf zal ik toelichten hoe ik deze data verworven en verwerkt heb. Zodat tevens duidelijk wordt hoe ik aan de eisen die aan deugdelijk onderzock worden gesteld, tegemoet gekomen ben ${ }^{87}$.

Aangezien de vraag van deze studie zich richt op publieke bemoeienis met zorg in de privésfeer en de thuiszorg onder directe financiële verantwoordelijkheid valt van de centrale overheid, heb ik me bij de selectie van beleidsteksten beperkt tot teksten van centrale overheden. I $\mathrm{k}$ heb in deze studie instanties die op centraal of landelijk niveau een beleidsrapport over informele zorg hebben geschreven tot 'de beleidsmakers' gerekend en een selectie van beleidsteksten over informele zorg van de centrale overheid en haar adviesorganen in de analyse betrokken (zie bijlage $\bar{i}{ }^{88}$. Ik begon te lezen in rapporten over informele zorg geschreven in de jaren negentig. Letrend op verwijzingen in de rapporten naar andere, eerdere beleidsrapporten ben ik zo terug in de tijd gegaan. De aldus geselecteerde en verbonden verzameling teksten is geschreven tussen 1974 en 1997 en hebben als overeenkomst dat we ze zien als publieke en dus invloedrijke betekenisproducenten.

Zoals gezegd heb ik in deze teksten gezocht naar veel voorkomende woorden. Woorden die bij elkaar hoorden, heb ik tot thema's geclusterd. Zo kwam ik tot de 
thema's 'verzorger', 'thuis' en 'kennis'. De zinsdelen en paragrafen uit het beleid die hieraan gerelateerd zijn, heb ik letterlijk overgetypt en naar dichotomieën gecodeerd met behulp van het programma Kwalitan.

De andere data (tegenverhalen) zijn verschillend van aard en afkomstig van twee groepen die een belangrijke bijdrage aan deze beleidsanalyse van informele zorg leveren, namelijk wetenschappelijke teksten en verhalen van informele verzorgers ${ }^{{ }^{8}}$. Een selectie van wetenschappelijke teksten is op trefwoord gezocht. Hierbij is gebruik gemaakt van het zoekprogramma 'Medline'. Trefwoorden waren: 'informal care' of een combinatie van 'informal care' en 'cancer'. De aldus gevonden onderzoeksverslagen zijn opgevraagd en via de sneeuwbalmethode is verder gezocht. Een geselecteerd bestand van deze wetenschappelijke artikelen is geschreven tussen 1972 en 1998 (bijlage 2). In beleid verwijst men vaak naar werenschap. De ideeẻn in dit tekstgenre zijn voor beleidsmakers klaarblijkelijk 'significante uitspraken' en vormen voor hen een belangrijke context (of intertekst).

In de wetenschappelijke teksten heb ik vooral gezocht naar woorden, zinsdelen en paragrafen die betrekking hebben op her thema 'verzorger'. Ik heb geanalyseerd welke betekenis wetenschappers aan verzorgers geven en hoe deze gedurende de jaren verandert. Zo ontdekte ik een patroon. Als zich ogenschijnlijke 'deviante gevallen' aandienden bijvoorbeeld wetenschappers die een andere betekenis aan verzorgers gaven dan de meest gangbare, stopte de analyse niet. Juist dan analyseerde ik verder zodat een zo'n genuanceerd mogelijk (valide) patroon beschreven kon worden ${ }^{\circ}$.

Bij de tocwijzing van de reksten tot de wetenschappelijke-, of de beleidscategorie doet zich echer wel een moeilijkheid voor. Er is 'een grijs gebied' tussen beide werelden. Zo is her de vraag of ik de Wetenschappelijke Raad voor het Regeringbeleid als beleid of wetenschap moet typeren. Ook is het plaatsen van artikelen van bijvoorbeeld professor Hattinga Verschure niet eenvoudig omdat deze als politiek pleidooi gelezen kunnen worden. Of de tekst gelezen is als beleidstekst of als context heb ik laten afhangen van de intentie waarmee de uitspraken zijn gedaan. De Wetenschappelijke Raad voor het Regeringsbeleid draagt primair bouwstenen aan voor beleid, dat geldt, grosso modo, minder voor medewerkers van de universiteit zoals professor Hattinga Verschure.

Naast wetenschappelijke teksten zijn bij de analyse van beleid, verhalen van informele verzorgers gebruikt. Dit zijn reksten van acroren die dit beleid ondervinden en mede vormgeven. Evenals wetenschappers spreken ook zij in evaluerende termen. Deze teksten zijn niet publiekelijk en vormen daarom een moeilijker te traceren context. Ze zijn interessant omdat het contrast met de beleidswereld evident is. 
Zoals gezegd, hebben verschillende onderzoekers in Nederland, maar ook daarbuiten, verhalen van verzorgers opgetekend. In deze studies worden verzorgers op drie manieren gecaregoriseerd ${ }^{91}$. Zo kunnen kenmerken van verzorgers als indeling dienen. Onderzoekers onderscheiden mannelijke verzorgers, kinderen die zorgen of vrouwen van middelbare leefrijd. Een tweede manier om deze groep te ordenen is door de relatie tot de verzorgde aan te geven. Dan onderscheidt men bijvoorbeeld partners, dochters of kerkgenoten. Tot slot is er een indeling die de kenmerken van de verzorgde als indelingssfactor hanteert. Bij deze indeling gaat het veelal om verzorgers van patiënten met een bepaalde aandoening. Uit deze laatst genoemde onderzoeken komt naar voren dat iedere groep informele verzorgers, zoals verzorgers van dementerenden, chronisch zieken of cva-patiënten, specifieke deskundigheden nodig heeft. Ze hebben eigen mogelijkheden en problemen ${ }^{92}$.

In dit onderzoek zijn informele verzorgers van pariënten met kanker geïnterviewd. Het spreekt voor zich dat het hier om een bijzondere categorie verzorgers gaat. Ze hebben de zieke vaak tot de dood thuis verzorgd en tal van aspecten spelen daarbij een rol. Zo is het bijvoorbeeld bekend dat het voor betrokkenen en hun onderlinge communicatie van belang is of zii al dan niet 'beseffen' of de patiënt dood gaat ${ }^{93}$. In de 'besloten besef-context' weet de zieke niet van de ernst van de situatie, terwijl de naasten wel op de hoogte zijn. In 'het vermoedendbesef' heeft de zieke het voorgevoel dood te gaan en probeert daarover bijvoorbeeld bij zijn verzorgers zekerheid te krijgen. Het 'doen- alsof-besef' houdt in dat de zieke en zijn verzorger de ernst van de situatie weten. Ze vermijden echter hierover te spreken. Tor slot 'het open-besef' waarbij zowel de zieke als diens verzorger weten dar de dood nabij is en daar open over communiceren. Gaande het ziekteproces kan de ene besef-context plaars maken voor de andere. De besef-context zal dus van belang zijn voor de beschrijving die verzorgers van het zorgproces thuis geven. Dergelijke processen, maar bijvoorbeeld ook de duur van het zorgproces, de relatie tot de zieke, de organisatie van de thuiszorg en de relatie met professionele verzorgers karakteriseren de ervaringen van deze verzorgers"

De informele verzorgers zijn in januari 1993 via het tijdschrift 'de Margriet' benaderd. De lezers van dit blad verzocht ik omwille van mijn promotieonderzoek naar thuiszorg bij patiënten met kanker, hierover te vertellen. Bij de plaatsing van 'dit oproepje' is toen in overweging genomen dat het sinds jaren voornamelijk vrouwelijke partners, (schoon)dochters, (schoon)zusters en moeders zijn die informele zorg verlenen ${ }^{95}$. Een oproep in een damesblad leek hiermee gelegirimeerd. Een mogelijk nadeel van een dergelijke werving is dat er een tamelijk homogene groep vrouwen is benaderd. Margriet behoort tot de traditionele weekbladen voor vrouwen. Dit blad is gericht op huis en haard, koken, mode en inrich- 
ting, op baby's en moederschap, zaken die in de conventionele Nederlandse gezinssetting 'vrouwenzaken' zouden zijn. Zoals verwacht waren de meeste reacries dan ook van blanke autochtone vrouwen die in deze conventionele gezinssetting leven. Maar aangezien dit onderzoek niet (primaire) tot doel heeft algemene uirspraken over informele verzorgers te doen, maar tot inzet heeft gender-conventies in beleid op te sporen voldeden deze in ruime mate.

Er kwamen veel reacties op het oproepje. Binnen korte tijd reageerden 60 lezers ${ }^{96}$. Zoals verwacht was het merendeel hiervan vrouw maar ook mannen, zelfs een echtpaar wilden me te woord staan. De aard van de respons beantwoordde aan de doelstelling van een dergelijke oproep (bijlage 3). Zo was ег binnen deze groep genoeg variatie, waren er naast sekse-verschillen, reacties uit praktisch het hele land, varieerde de leefrijd van de verzorgenden van 22 tor 70 jaar en was de aard van de relatie tor de zieke verschillend. Bovendien trof ik mensen die graag bereid waren hun geschiedenis te vertellen. Daarnaast kreeg ik tientallen brieven. Sommige verzorgers lieten enkel weten mee te willen werken aam het onderzoek, andere stuurden meteen al een vrij uitvoerig verslag van de ziekteperiode van een dierbaar persoon. Het was een onverwacht groot aantal reacties. Dit maakte dat naast de 20 diepte-interviews (het verzadigingspunt was bereikr) ook 30 vragenlijsten verstuurd zijn. Hierin verzocht ik enkele open vragen te beantwoorden waarin de ervaring als informele zorgverlener tot uirdrukking kwam (bijlage 3) ${ }^{97}$. Het zou immers een gemiste kans zijn om deze potentiële informatiebron niet te benutten.

Zowel de spontane reakries, de interviews als de antwoorden op de vragen in de vragenlijst zijn geanonimiseerd en letterlijk uitgetypt. Omdat her me in hoofdzaak om de woorden ging, lette ik hierbij niet op intonatie, haperen of stiltes. Afgezien hiervan was het een volledig transcript. Ik clusterde de woorden behorend bij de thema's: 'thuis' en 'kennis'. Vervolgens codeerde ik binnen deze thema's op de eerder genoemde dichotomieën met behulp van het analyseprogramma Kwalitan.

Het optekenen van verhalen van informele verzorgers is in deze studie vooral bedoeld om een vergelijking tussen de verschillende vertogen te kunnen maken. Ze dienen om gender-conventies in beleid (eenvoudiger) op te kunnen sporen. In dit onderzoek beschouw ik beleid, wetenschap en de verhalen van verzorgers als eenheden ofwel werelden met eenzelfde kleur. Variaties binnen de werelden bijvoorbeeld vanwege tradities in onderzoek of verschil in levensstijl bij verzorgers komen minder aan bod. Dit komt omdat dit onderzoek leunt op overeenkomsten en verschillen tussen werelden ofwel de idee van 'intertekstualiteit' ${ }^{88}$. Bovenal wil het inzicht geven in het impliciete gender-karakter van het informele zorgbeleid. Daarom ben ik meer geïnteresseerd in variatie tussen de verschillende werelden dan daarbinnen. Behalve dat teksten uit de wetenschap en van verzor- 
gers een hulpmiddel bij de beleidsanalyse zijn, impliceert een vergelijking van verschillende vertogen ook de idee dat niet alleen beleidsmakers beleid vormen, maar dat bijvoorbeeld wetenschappers en informele verzorgers te zien zijn als actoren die actief handelen en zich niet zonder meer invoegen in een beleid gericht op informele zorg zoals geformuleerd door de overheid. Ze beschouwen dominante ideeën en praktijken kritisch en dragen hiervoor alternatieve teksten aan. Hoewel men beleidsmakers over het algemeen beschouwt als invloedrijke vertelinstanties, wil dat dus niet zeggen dat anderen hun vertellingen zonder meer overnemen $\%$.

\section{Probleemstelling en vervolg}

Tot zover is in dit hoofdstuk eun introductic gegeven op het object van studic, beleid over thuiszorg en informele zorg. De studie is in een wetenschappelijke, constructivistische traditie geplaatst. Op basis van de opvatting over beleid, de theorerische uitgangspunten van dit onderzoek en de daarbij horende methode luidt de uiteindelijke probleemstelling van dit onderzoek:

Welke (gender)conventies (re)prodwceren beleidsmakers in het informele-zorgbeleid en hoe zijn deze gerelateerd aan teksten van wetenschappers over informele zorg en verhalen van verzorgers?

Omdat ik de conventies achterhaal door een vergelijking van het informele-zorgbeleid met het wetenschappelijk vertoog en het 'praktisch' zorgvertoog, zal ik ook beschrijven hoe deze vertogen zich tot elkaar verhouden. Het doel van deze deconstructie van het informele-zorgbeleid is tweeledig. Enerzijds wil ik inzicht geven in het normatieve karakter van het informele-zorgbeleid. Het is een gender-reflectie op bestaand beleid (wetenschappelijke relevantie). Daarbij zal ik ook nagaan wat de conventies betekenen voor de praktijk van de informele zorg. Ik onderzoek ook de doorwerking van het beleidsvertoog in de praktijk van verzorgers en sta stil bij de vraag wat gender-conventies in beleid voor de praktijk van de verzorgers betekenen (maatschappelijke relevantie)?

Door de aard van het beleid, de gebruikte theoretische concepten en het doel van de analyse begeeft dit onderzoek zich op de grens van beleidswetenschap en vrouwenstudies ${ }^{100}$. In dit hoofdstuk zijn dan ook enkele voor deze studie relevante concepten en ideeën uit deze disciplines besproken. Dit onderzoek naar beleid en gender is het resultaat van een inhoudelijke kruisbestuiving van verwante maar verschillende onderzoeksterreinen. Terwijl in de beleidswetenschap de visie aan aandacht wint dat 'beleid' een talige aangelegenheid is, heeft zich binnen vrou- 
wenstudies een vergelijkbare paradigmatische verschuiving voorgedaan in het denken over gender ${ }^{10}$. De studie is ook de uitkomst van een zoektocht met als doel inzicht te geven in gender-conventies in het informele-zorgbeleid opdat dit weer inzicht geeft in de mate waarin beleid sekse-stereotiepe beelden inprogrammeert en beleidsmakers op die manier onbedoeld bestaande waarden voortzetten. Uiteindelijk is deze analyse een voorzichtige eerste stap op weg naar het herformuleren van gestolde gender-conventies in het zorgbeleid.

In de komende hoofdstukken zal ik enkele veronderstellingen die respectievelijk verbonden zijn met de thema's 'verzorger', 'thuis' en 'kennis' bespreken en wel op zo'n manier dat deze steeds leiden naar een gender-conventie in beleid. Deze werkwijze is terug te zien in de structuur van de hoofdstukken. Het hoofdverhaal is dat van beleidsmakers; het tegenverhaal komt van wetenschappers of van informele verzorgers. Door een vergelijking van conventies uit de verschillende verrogen destilleer ik dan een 'meta-verhaal' ofwel ik beschrijf een gender-conventie in beleid.

In hoofdstuk twee zal ik beleid met wetenschap vergelijken. Ik stel de vraag welke conventies zich over de aard van informele zorg in het beleid manifesteren. Hoewel her informele-zorgbeleid relatief jong is, geef ik een historische schets waarbij ik op basis van de vraagstelling verschillende fasen in het informele-zorgbeleid onderscheid. De verschuiving in betekenis van informele zorg enerzijds en de vergelijking met het wetenschappelijk vertoog anderzijds brengen me bij een (gender)conventie in beleid omtrent de aard van zorgarbeid.

In hoofdstuk drie en vier zal ik beleid met teksten van informele verzorgers vergelijken. In hoofdstuk drie staat de verhouding russen verzorger en patiënt centraal. Welke conventies staan in het beleid over 'de patiënt' en wat zeggen beleidsmakers over de locatie waar informele verzorgers hun arbeid verrichten? Met andere woorden hoe definiëren beleidsmakers de 'patiënt' en 'thuis'? Met welke waarden brengen ze deze concepten in verband? Juist datgene wat het beleid niet verwoordt, geeft aanzet tor een (gender)conventie over de positie van de verzorger in beleid.

In het vierde hoofdstuk richt de analyse zich op de verhouding tussen informele en professionele verzorger. Hoe onderscheiden beleidsmakers leken van professionals? Welke competenties krijgen ze toebedeeld? En hoe scheiden ze beider domeinen? Deze vergelijking brengt me bij een derde (gender)conventie die betrekking heeft op de conceptualisering en definiëring van zorgkwaliteiten van verzorgers in beleid.

In hoofdstuk vijf, tor slot, zal ik de opbrengst van deze constructivistische beleidsanalyse beschrijven. Het moet duidelijk worden wat de winst is om niet én, maar verschillende teksten in deze beleidsanalyse te betrekken. Wat, kortom 
de waarde van een vertooganalyse is. Ik beschrijf de verschillende conventies en hun betekenis voor verzorgers en kom zo terug op de vraag hoe de overheid ingrijpt in zo'n private zaak als informele zorg. Taal en dus overheidsnota's grijpen in op de werkelijkheid. Ze schrijven informele verzorgers bijvoorbeeld gedragsrepertoires voor. Ik zal laten zien hoe (gender)-specifiek het ingrijpen van de overheid is. Recente bemoeienis van de overheid betekent nier alleen dat de overheid informele zorg aanmoedigt, maar ze definieert ook wat goede zorg is en hoe een verzorger zich behoort op te stellen om een succesvol verzorger te zijn. In het laatste deel van het hoofdstuk, tot slot, zal ik reflecteren op de vraag wat dit voor verzorgers betekent. 



\section{De mantel der liefde}

Mijn moeder was een heel lief mens, als je bedenkt dat ze gedurende haar leven 40 kinderen van andere mensen heeft grootgebracht dan zegt dat wel iets. Toen artsen een tumor in haar hersenen constateerden, woonde bij haar een aangenomen zwakbegaafd kind en een verstandelijk gehandicapte zus van mijn vader.

Toen mama ziek werd, zat ik ook net in de ziektewet. Ik dacht: 'Weer geen rust in de tent.' Maar goed op zo'n moment zet je jezelf aan de kant. Dat deden mijn zus en mijn broers ook, voor zover mogelijk.

Iedere ochtend ging mijn zus van 8.30 uur tot 13.00 uur naar het huis van mijn ouders toe. Zij werkte normaliter bij haar man in het bedrijf. $Z e$ doet daar de hele boekhouding. Dat deed ze toen in de avonduren. Iedere middag kwam ik. Ik bleef dan tot het avondeten of totdat de nachtdienst kwam. Zoals ik zei was ik, op dat moment ziek thuis. Een geluk bij een. ongeluk.

Onze broers wonen hier $200 \mathrm{~km}$ vandaan. Mijn jongste broer, die heel erg gehecht is aan mijn moeder, kwam bijna elke avond naar hier. Hij had het zo geregeld dat hij in die tijd niet voor zijn werk naar het buitenland hoefde. Mijn andere broers kwamen in het weekend, ze namen ook wel eens vrijdags vrij. Hun hele vakantie is aan de ziekte van moeder op gegaan. Een van mijn broers heeft die zorgdagen wel van zijn bedrijf terug gekregen.

Ik. weet wel dat ze op hun werk opmerkingen kregen. Mantelzorg, daar hadden ze in de stad nog nooit van gehoord. Ze vonden dat al raar, maar dat het ook nog jongens waren die zoveel voor bun moeder deden, dat sloeg alles.

Uit een interview met een dochter die voor haar moeder zorgde 


\section{Zwakke Zorgenden}

Informele zarg is belangrijk en omvangrijk. Van mensen met een handicap krijgt 69 procent uitsluitend informele hulp. Vooral familieleden, in het bijzonder vrouwen, verschaffen veel meer hulp aan ouderen dan professionele werkers.'.

'Het verlenen van mantelzorg is belastend. De mate waarin deze belasting wordt ervaren is afhankelijk van een aantal factoren, waarvan met name die op emotioneel terrein, bijvoorbeeld met betrekking tot de relatie tussen zorgverlener en -ontvanger, de onderliggende motivatie en de mate waarin men waardering ondervindt voor de verleende mantelzorg, zwaar wegen ${ }^{2}$.'

\section{Inleiding}

Impliciete veronderstellingen, conventies in zorgbeleid variëren. Dat maakt onderzoek ernaar juist zo interessant. De ene groep beleidsmakers gaat er misschien vanuit dat vrouwen zorg verlenen, de andere dat mannen in toenemende mate zorgtaken verrichten. Zorgbeleid vanuit een Ministerie kan vergrijzing van de bevolking veronderstellen, terwijl het beleid van een ziekenhuis in een jonge gemeente uitgaat van een groeiende populatie van 20- tot 40-jarigen. Ook kunnen beleidsmakers eerst uitgaan van een gezondheidszorgsysteem gebaseerd op inzet van professionals, terwijl ze later informele zorg beschouwen als bouwsteen voor dit systeem.

In dit hoofdstuk zal ik nagaan hoe dergelijke conventies gedurende het informele zorgbeleid verschoven zijn en let daarbij vooral op gender-aspecten. Zoals in hoofdstuk één beschreven zal ik een vergelijkende analyse plegen, omdar dir laat zien hoe het beleidsvertoog verweven is met andere vertogen en waarin het verschilt. Meer specifiek vergelijk ik in dit hoofdstuk conventies in beleid met conventies uit werenschappelijke artikelen over informele zorg die geschreven zijn vanuit een sociologische, gerontologische of psychologische invalshoek.

Onderzoek draagt vaak bij aan beleid. Het is moeilijk aan te geven hoe dat precies gebeurt, hoe wetenschap zich tot beleid verhoudr. Zo zouden beleidsmakers onderzoeksresultaten meteen kunnen vertalen in beleidsmaatregelen. Maar onderzoek kan ook indirecter de manier van denken van beleidsmakers beïnvloeden of louter een legitimerende of politieke functie vervullen. Beleidswetenschappers gaan er dus vanuit dat er verschillende manieren zijn waarop wetenschap 
beleid voedt ${ }^{3}$. In dit hoofdstuk onderzoek ik hoe conventies over informele zorg zijn verschoven en hoe beleid en wetenschap zich op dat vlak tot elkaar verhouden.

In het informele-zorgbeleid zal ik drie perioden onderscheiden, waarbij steeds een andere conventie over informele zorg centraal staat. De eerste periode, de start van het informele-zorgbeleid in Nederland, loopt ongeveer van halverwege jaren zeventig tor halverwege de jaren tachtig. In die tijd benadrukken beleidsmakers vooral de kracht van informele verzorgers en pleiten voor op- of herwaardering van hun arbeid binnen het zorgsysteem. I laat de rweede periode halverwege de jaren tachtig beginnen. Dat is wanneer beleidsmakers zich afvragen of er wel een groter beroep gedaan kan worden op informele zorg, bijvoorbeeld omdat vrouwen steeds vaker de arbeidsmarkt betreden. Op het moment dat ze oplossingen aandragen om het verwachte tekort aan verzorgers op te vangen gaat deze periode over in een andere. Dat is begin jaren negentig. Het beleid kenmerkt zich dan door beleidsvoorstellen die ertoe bij moeten dragen dat het zorgpotentieel gehandhaafd blijft en de kwaliteit van informele zorg gewaarborgd. Natuurlijk zijn deze periodes niet precies af te bakenen, dat is dan ook niet de inzet van dit hoofdstuk. Bovenstaande indeling betekent evenmin dat de ene conventie volledig plaats maakt voor de andere; conventies bestaan naast elkaar. Waar het om gaat is dat deze analyse laat zien dat conventies over informele zorg langzaam veranderen, welke variatie er is en wat de verschuiving betekent voor een (genderspecifieke) beschrijving van informele zorg.

ledere periode beschrijf ik in twee paragrafen, waarbij in de eerste paragraaf steeds het informele zorgbeleid centraal staat om dit in de tweede paragraaf te vergelijken met het wetenschappelijk vertoog daarover. Aan het eind van dit hoofdstuk trek ik verschillende conclusies. Ik ga enerzijds in op de vraag hoe beleidsconventies zich tot werenschappelijke conventies verhouden. Anderzijds bespreek $i k$ de gevolgen van gender-conventies in beleid voor de praktijk van verzorgers.

\section{Het belang van informele zorg}

Hoewel verzorging van naasten al eeuwenlang bestaat, is er tot de jaren tachtig in beleid in Nederland weinig interesse voor dit type zorg. Dan pas verschijnen de termen 'mantelzorg' en 'informele zorg' als pendanten van 'professionele zorg' of 'formele zorg'. Informele verzorgers worden een beleidsissue en zijn niet langer 'het stiefkind' van het sociaal beleid' 4 .

De beleidsmatige interesse voor informele zorg in Nederland zou een gevolg zijn van 'het systeem' of 'structuurdenken' dat ingang vindt'. De gezondheidszorg zou, 
aldus beleidsmakers, moeilijk te besturen zün vanwege een gebrek aan samenhang russen gezondheidsvoorzieningen ${ }^{6}$. De instellingen in de gezondheidszorg werken niet doelmatig en daardoor zijn de kosten te hoog. Beleidsmakers stellen voor de verschillende instellingen in de gezondheidszorg nier langer als losse onderdelen re beschouwen en te benaderen, maar als een verzameling elementen die onlosmakelijk met elkaar verbonden zijn. Een (her)verdeling in nulde,- eerste, - en tweede lijn of wel de zogenaamde 'echelonnering' van de gezondheidszorg zou hiertoe bijdragen. De Structuurnota introduceert 'een gesloten circuir' of 'systeem' van zorgvoorzieningen.

Dit 'echelonneringsidee' staat ook centraal in latere nota's zoals Volksgezondheid bij Beperkte Middelen (1983) en de Nota Eerstelijnszorg (1983) waarin de gedachte van een nieuw gezondheidszorgsysteem verder gestalte krijgt. Het nulde echelon van het zorgcircuit staat in deze laatste nota voor zelfzorg en informele zorg. Hiermee duiden beleidsmakers het circuit waarbinnen mensen, zonder of in combinatie met interventies van professionele hulpverleners, zorg dragen voor zichzelf en voor anderen. Her gaat dan om het zelfstandig verhelpen van verstoringen in het lichamelijk, psychisch of sociaal welbevinden. Vervolgens definiëren ze het eerste echelon als thuiszorg en gespecialiseerde zorg. Dit omschrijven ze als een subsysteem van zorg waarin professionele werkers de medeverantwoordelijkheid op zich nemen voor een continue, integrale en persoonlijke zorg in de eigen omgeving van de mensen aan wie de zorg wordt verleend. Hieronder vallen bijvoorbeeld medewerkers van thuiszorgorganisaties, huisartspraktijken en praktijken van vrijgevesrigde psychologen. Tot slot onderscheiden beleidsmakers het tweede echelon dat staat voor residentiële zorg ${ }^{7}$. Dit is zorg die niet vrij toegankelijk is, maar alleen via de eerste lijn bereikt kan worden. Voorbeelden hiervan zijn zorg binnen revalidatiecentra, algemene ziekenhuizen en voorzieningen voor de geestelijke gezondheidszorg zoals een 'riagg'.

residentiële zorg

2-de echelon of lijn

I-ste echelon of lijn = thuiszorg

0-de echelon of lijn = zelfzorg informele zorg

Deze structuur heeft tot doel een zorgcircuit te creëren waardoor collectieve gezondheidszorgvoorzieningen beter bestuurbaar zouden zijn en de totale kosten van de gezondheidszorg beter beheersbaar ${ }^{8}$. Stimulering van het nulde echelon 
moet bewerkstelligen dat zo min mogelijk beroep wordt gedaan op het duurdere eerste en tweede echelon.

Met de introductie van de echelonneringsgedachte wordt informele zorg voor het eerst onderwerp van beleid. Informele verzorgers krijgen een naam, een plaats in het nulde echelon en zijn daarmee erkend als wezenlijk deel van het grote gezondheidszorgsysteem. Hierbij veronderstellen beleidsmakers bijzondere zorgkwaliteiten van informele verzorgers en zetten deze steevast af tegen kwaliteiten van professionele verzorgers uit het eerste echelon. Enerzijds relativeert het beleid de mogelijkheden van de professionele zorg, anderzijds roemt ze die van de informele zorg.

Professionele verzorgers zouden volgens beleidsmakers slechts een klein percentage van de gevraagde zorg leveren. Vergelijking van de inbreng van professionele zorg met die van de informele zorg, toont aan dat de inzet van informele verzorgers altijd al aanzienlijk was. Familie en vrienden zouden, hoewel onzichtbaar en daardoor moeilijk meetbaar, minstens vier keer zoveel zorg geven als beroepskrachten.

'Wat betreft de verpleging en verzorging kan geconstateerd worden dat de meeste burgers in dit land in hun leefverbanden in staat zijn om zichzelf te verzorgen en elkaar indien nodig te verzorgen en te verplegen. (...) Een indicatie van de kwantitatieve verhoudingen tussen zelf- en mantelzorg enerzijds en professionele zorg anderzijds vormt onderstaande tabel (...) miljoenen uren per jaar

$\begin{array}{lc}\text {-zelfzorg } & 15.000 \\ \text {-mantelzorg } & 3.000 \\ \text {-vrijwilligerswerk } & 90 \\ \text {-professionele zorg } & 400^{9} .\end{array}$

Overheid noch professionele zorgverleners zouden, aldus het beleid, in staat zijn zonder actieve betrokkenheid van de informele zorg een goede zorgverlening tor stand te brengen en in stand te houden ${ }^{10}$. Er zou sprake zijn van overtrokken en ongegronde verwachtingen van de mogelijkheden van professionele hulp".

Beleidsmakers roemen niet alleen de kwantitatieve inbreng van informeel verzorgenden. Er zou in een tijd van sterke ontwikkeling van de professionele zorg te weinig aandacht besteed zijn aan andere kwaliteiten van hen. Deze liggen op verschillende fronten en zijn ook in het voorgaande hoofdstuk genoemd. Zo zou bijvoorbeeld de inzet van thuiszorg en daarmee van informele verzorgers de totale gezondheidszorg goedkoper maken.

'Her kostenvraagstuk werd in de jaren tachrig voor de zorgsector zo problematisch dat intensief gezocht werd naar mogelijkheden om de kosten te beperken. 


\section{Uiteindelijk bleek het grootste effect te verwachten van maatregelen waarbij dure opnames door goedkope thuiszorg werden vervangen ".'}

Tevens zouden burgers informele zorg thuis verkiezen boven zorg van professionals in instituten.

'Velen lijken thans daarom weer de voorkeur te geven aan het sterven thuis temidden van hun naaste familie. Het ziekenhuis en/of verpleeghuis heeft kennelink pas weer de voorkeur in siruaties waarin het niet anders kan ${ }^{n}{ }^{\prime}$ '

Tot slot zou informele zorg waardevol zijn omdat ze, in vergelijking tot zorg uit het eerste en tweede echelon, oprimal bijdraagt aan zelfstandigheid van burgers. Zo $n$ uitsprak veronderstelt wel dat burgers zelfstandig willen zijn en zelf richting geven aan hun leven. Beleidsmakers nemen dit aan en pleiten ervoor dat er geen onnodig zelfstandigheidsverlies van burgers mag zijn.

a. Mensen dienen zo lang mogelijk zelfstandig in hun eigen omgeving te blijven. b. Er dient nadruk te worden gelegd op de individuele verantwoordelijkheid voor de eigen gezondheid en zorg voor zichzelf, maar ook op die voor de gezondheid en zorg van/en voor anderen (zelfzorg, mantelzorg, georganiseerde vormen van vrijwilligerswerk) ${ }^{44}$ '

'Met het oog op zowel de zelfstandigheid van de patiënt als de betaalbaarheid van de gehele gezondheidszorg zal moeten worden gestreefd naar een nog selectievere -dan tor dusver gebruikelijk- van professionele hulp en (geavanceerde) technieken "s."

'De zelfstandigheid van mensen moet uit het oogpunt van kwaliteit van leven zolang mogelijk gehandhaafd blijven: dit betekent enerzijds dat zoveel mogelijk moet worden voorkomen dat mensen chronisch afhankelijk worden van professionele zorg en anderzijds dat professionele zorgverlening er waar mogelijk aan bijdraagt dat mensen zelfstandig blijven: professionele zorg moet aanvullend zijn op zelf- en mantelzorg ${ }^{16}$.'

Zoals uit bovenstaande citaten op te maken is, waarderen beleidsmakers informele zorg niet alleen, maar gaan ze dit ten opzichte van professionele zorg zelf́s propageren.

Professionele zorg zou nog lourer aanvullend op informele zorg mogen zijn ${ }^{7}$. Met het oog op de zelfstandigheid van mensen streven beleidsmakers dan naar een selectievere inzet van professionele zorg dan tot dusver gebruikelijk is ${ }^{i 8}$. Beleidsmakers zijn van mening dat burgers eerst zelf moeten zorgen en pas in tweede 
instantie professionele zorg mogen inschakelen. Pas wanneer de problemen voor de eigen mogelijkheden te groot zijn, kan professionele hulp worden ingeroepen, te beginnen in de eerste lijn "'. Burgers zouden zich dus alleen nog tot professionele zorg mogen wenden als de informele zorg het niet redt. Informele zorg boven professionele zorg is het beleidsdevies ${ }^{20}$.

Samengevat definiëren beleidsmakers informele zorg in die eerste periode als een subsysteem van het zorgcircuit dat in het bijzonder bijdraagt aan vermindering van de kosten in de gezondheidszorg. In nauwe samenhang daarmee pleiten ze voor zelfstandigheid van burgers. Deze zelfstandigheid zou het best tot z'n recht komen in her circuit waartoe de informele zorg behoort. Beleidsmakers stellen informele zorg, binnen het door hen geconstrueerde zorgsysteem, voor als de meest gewenste vorm van zorg omdat het kosten bespaart en zelfstandigheid van burgers bevordert. Informele zorg is voor de gezondheidszorg van enorm belang. Om na te gaan of dit een unieke conventie is stel ik nu de vraag hoe wetenschappers informele zorg in hun vertoog eind jaren zeventig, begin tachriger jaren definiëren? Welke waardering geeft men daar?

\section{De kracht van sociale netwerken}

Binnen de sociaal-wetenschappelijke wereld in Nederland ontwikkelt zich in de jaren zeventig, begin jaren tachtig een traditie die kwesties onderzoekt die verband houden mer een toenemende invloed van medici in her leven van mensen. De geneeskunde en aanverwante vakgebieden hebben veel goeds teweeg gebracht, zo is het standpunt, maar al dat goeds heeft ook een keerzijde. In West Europa en de Verenigde Staten ontstaat kritiek op de medische hulpverlening. Artsen, para-medische diensten en zorgprofessies bieden niet alleen hulp bij ziekte maar zijn ook ziekmakend. Zo zouden steeds meer dimensies van het menselijk bestaan onder controle van het zogenaamde medische regime komen en definiëren artsen steeds meer aspecten van her leven als ziekte ${ }^{2}$. Was zwangerschap bijvoorbeeld cerst een vanzelfsprekend en natuurlijk gegeven, deze levensperiode komt steeds vaker onder medische controle te staan. Waren schommelingen in het slaappatroon voorheen een biologisch gegeven, thans is het bijna vanzelfsprekend dat artsen hiertegen medicijnen voorschrijven. Door dergelijke infiltraties van medici in het leven van burgers breidt de medische macht zich uit, met als gevolg dat de persoonlijke autonomie van mensen wordt uitgehold en mensen beslissingen over hun bestaan uit handen worden genomen, aldus de critici ${ }^{22}$.

Voor sommige onderzoekers is de veronderstelling dat artsen, verpleegkundigen en andere zorgprofessionals ziekte bestendigen en autonomie beperken een belang- 
rijke bron van inspiratie. Zij starten onderıock en houden pleidooien voor een nieuw gezondheidszorghestel vanuit de overtuiging dat zelfzorg en mantelıro ren opzichte van professionele zorg opgewaardeerd moet worden. Tevens propageren ze alternatieve hulpverleningsvormen zoals de vrouwenhulpverlening en zelfhulpgroepen.

Een voorbeeld van zo'n toonaangevende Nederlandse auteur uit die tijd is de hoogleraar Ziekenhuiswetenschappen Hatringa Verschure. Hij vestigt aandacht op zelfzorg- en mantelzorg als voorwaarden voor een goede gezondheid. Mantelzorg (of informele zorg) definieert hij als zorgverlening die binnen sociale netwerken door de 'genoten' in dat netwerk aan elkaar wordt gegeven op basis van bereidheid tot wederkerigheid. Kenmerkend voor die zorg zou de persoonlijke betrokkenheid, toewijding en bezorgdheid van betrokkenen zijn. Dit type zorg zou per definitie een emotioneel karakter hebben. Hatringa Verschure beschouwt 'de huishouding', oftewel her gezin in al zijn vormen, als het basale zorgnetwerk. Daaromheen funcrioneert een secundair nerwerk van vrienden, buren of 'de buurt'. Door middel van artikelen en lezingen vestigt hij in Nederland aandacht op de grote betekenis van informele zorg, in zijn woorden 'het natuurlijk zorgpatroon', voor de gezondheid van het individu. Tevens houdt hij pleidooien om binnen opleidingen en onderzoek in de gezondheidszorg meer aandacht hiervoor te krijgen ${ }^{23}$.

Naast een onderzoekstraditie geïnspireerd door de nadelige invloeden van medisch denken, bestaat een traditie met een minder normarief uirgangspunt. In deze traditie bestuderen onderzoekers het belang van een sociaal netwerk voor individuen (ouderen of zieken). Zij vragen zich bijvoorbeeld af hoe groor een gemiddeld sociaal netwerk is of welke betekenis dit netwerk heeft voor de gezondheid van individuen? En meer specifiek: Hoe beïnvloedt een sociaal netwerk het welzijn van ouderen? Hoe beïnvloedt een sociaal netwerk het ziektebeloop? Of hoe waarderen patiënten zorg van de familie in vergelijking tot professionele zorg? Deze stroming binnen het sociologische, gerontologische onderzoek naar zorg is vernieuwend, omdat vóór die tijd meestal de patiënt of oudere in het onderzoek centraal stond.

Diverse onderzoeken naar sociale netwerken laten zien dat familiaire zorg het welbevinden van patiënten meer bevordert dan professionele zorg. Daarmee heeft het familiaire netwerk een positieve invloed op de gezondheid. Dit geldt niet alleen bij psychosociale - maar ook bij lichamelijke klachten ${ }^{24}$. Patiënten met pijn bijvoorbeeld hebben vanwege interacties met de sociale omgeving, vooral de partner, minder pijn dan pariënten die het zonder deze contacten moeten stellen. Dit komt, aldus de onderzoekers, omdat het eigen levenspatroon gehandhaafd blijft. En juist vanwege de positieve invloed van de sociale omgeving op het ziekte ver- 
loop bij terminale patiënten, zouden patiënten ook in de laatste fase van hun leven het liefst met hun familie cq. 'eigen mensen' van doen hebben ${ }^{25}$.

Vooral in Amerika verschijnt een groot aantal studies waarin onderzoekers aantonen dat steun van de sociale omgeving in het algemeen en van familieleden in het bijzonder van cruciaal belang is voor het welzijn, de aanpassing en misschien zelfs voor de overleving van patiënten met kanker ${ }^{26}$. In deze context spelen partners een speciale rol. Zij voorzien in sociale en emotionele behoeften van patiën$\operatorname{ten}^{27}$. Ook in Nederland is, zij het wat later, onderzoek bekend dat laat zien dat sociale steun een positief effect heeft op de levensverwachting van patiënten met kanker ${ }^{28}$. Sociale contacten, mits afgestemd op de specifieke situatie en de persoonlijke eigenschappen van de patiënt, hebben een gunstige invloed op het welbevinden van patiënten met kanker en wellicht ook op het ziekteproces ${ }^{29}$. Toch is het verband tussen sociale steun en kwaliteit van leven bij patiënten met kanker niet eenvoudig aan te tonen. Een ander onderzoek toont bijvoorbeeld wel dat een toename van steun per lid van het primaire netwerk het beloop van de ziekte positief beïnvloedt, maar kan geen uitspraak doen over de vraag of een slechte kwaliteit van leven tot minder steun leidt of dat weinig steun leidt tot minder kwalireir van leven ${ }^{30}$. Hoewel onderzoekers over het algemeen aannemen dat de invloed van sociale factoren op het beloop van ziektes zoals kanker gunstig is, is deze aanname omstreden.

Samengevar: in de eerste periode waarin onderzoek naar 'informele zorg' wordt gedaan zijn twee stromingen te onderscheiden. De eerste stroming pleit ervoor de macht van medici te beperken. Opwaardering van lekenzorg ten opzichte van professionele zorg zou een dergelijk effect teweegbrengen. De tweede stroming is te duiden als het zogenoemde nerwerkenonderzoek dat een verband wil aantonen russen de sociale omgeving of sociale nerwerken en de gezondheid van (oudere) patiënten. Dit blijkt in vele gevallen positief. Onderzoekers belichten de gunstige invloed van sociale netwerken op de kwaliteir van leven van ouderen, patiënten in het algemeen en ook van patiëriten met kanker. Informele zorg, in dit verroog 'de sociale omgeving' genoemd, staat hier voornamelijk voor de bevordering van de kwaliteit van leven van patënten.

Vergelijken we beide vertogen, dan staat vanaf de jaren zeventig informele zorg zowel in beleid als in wetenschap in een positief daglicht. Beleidsmakers benadrukken het als waardevolle bron binnen en voor het totale gezondheidszorgsysteem. Wetenschappers leggen nadruk op de positieve invloed van de informele zorg op her welzijn en de gezondheid van patiënten. Naast een beleidsvertoog waarin verzorgers van belang zijn voor het instandhouden van een zorgsysteem, staat een wetenschappelijk vertoog dat de invloed van 'het informeel zorgsysteem' 
op het ziekteproces en de kwaliteit van leven van patiënten benadrukt. De vertogen passen in die zin goed bij elkaar.

Behalve dat beleidsmakers en wetenschappers informele verzorgers aanmerken als een waardevolle bijdrage aan het zorgsysteem en van belang achten voor patiënten, waren er zowel in beleid als wetenschap enkele verontrustende geluiden. Deze verontrusting gaat niet zozeer over de vraag of informele zorg een positieve bijdrage levert aan het zorgsysteem of zorgproces, maar over de vraag of het aantal informele verzorgers wel toereikend zal zijn.

\section{Een tekort aan verzorgsters}

Wanneer informele verzorgers begin jaren tachtig een plaats krijgen in het zorgbeleid, benadrukken beleidsmakers hun belang en kwaliteiten. Verzorgers zouden zelfs miskend zijn en een structurele plaats in het zorgsysteem verdienen. Beleidsmakers schetsen het informeel zorgcircuit als onmisbaar element voor het torstandkomen van een professioneel zorgarrangement, onder meer omdat informele zorg bijna altijd continuïteit waarborgt. Voor ouderen, gehandicapten en terminale patiënten is informele zorg van doorslaggevend belang. Deze zorg, zou zelfs zo omvangrijk zijn dat zij opname in een instelling voorkomt.

Naast waardering voor informele zorg, attenderen beleidsmakers in de loop van de jaren tachtig ook op een problematische kant. Dit heeft niet zozeer te maken met de kwaliteit van de geleverde zorg, maar met een (vermeende) ontoereikendheid van het aantal zorgenden. Beleidsmakers verwachten onder andere vanwege de vergrijzing van de bevolking een toenemende zorgvraag, ook van mensen die thuis willen overlijden ${ }^{31}$. Hierdoor neemt de druk op de informele zorg toe. Tegenover deze groeiende vraag naar zorg staat de verwachting dat het aantal informele verzorgers afneemt. Volgens beleidsmakers komen mogelijkheden van de informele zorg dan ook steeds meer onder druk te staan ${ }^{32}$.

De afname van informele zorg zou onder andere het gevolg zijn van een toenemende belasting van mensen in hun dagelijks leven, waardoor ze geen tijd meer hebben zorg te geven.

'(...), dat steeds minder mensen voldoende rijd hebben de zorg voor de bejaarde ouders of hulpbehoevende familieleden op zich te nemen ${ }^{33}$.'

Mensen kunnen volgens beleidsmakers dus minder naar een oude, hulpbehoevende buurman, vriendin of familielid gaan, simpelweg omdat de tijd ontbreekt. 
Naast het tijdgebrek beschouwen beleidsmakers veranderende gezinsstructuren als oorzaak voor een afnemend zorgpotentieel. Op de eerste plaats leven steeds meer mensen zonder partner en is het gemiddelde kindertal per gezin sterk gedaald. Dit zou betekenen dat het aantal burgers dat informele zorg kan geven ook vermindert. In verschillende nota's stelt men de vraag:

'(...) in hoeverre men kan blijven steunen op de hulp van een partner en als die ontbreekt, of er in de toekomst voldoende kinderen zijn om een beroep op te doen ${ }^{34}$.'

De beleidsassumptie is dus dat het aantal alleenstaanden zal stijgen en het aantal jongeren daalt. Ten tweede zullen kinderen zelden meer thuis bij hun ouders wonen tegen de tijd dat die ouders hulp nodig hebben.

'Door de sterke stijging van de levensverwachting en het afnemend kindertal is vooral sinds de jaren dertig van deze eeuw de lege-nest fase ontstaan. Dit betekent dat, als er een behoefte aan hulpverlening ontstaat, de kinderen dan al lange tijd het huis uit zijn is.'

Hierdoor ondervinden kinderen praktisch steeds meer belemmeringen zorg te geven aan hulpbehoevende ouders. Ze kunnen bijvoorbeeld moeilijker inspringen op acute zorgvragen of de dagelijkse boodschappen of de tuin verzorgen. Tenslotte is er volgens beleidsmakers niet alleen verandering opgetreden in de relatie tussen ouders en kinderen, maar ook in de relatie tussen ouders onderling. Veel ouders scheiden. Dat brengt meestal met zich mee dat ouders apart gaan wonen en de zieke (ouder) niet langer een beroep op de (ex)partner kan doen.

'Het roegenomen aantal echtscheidingen zal dit percentage [alleenwonenden] nog enigszins doen stijgen. Mantelzorg door huisgenoten is in deze situatie uitgesloten $(. . .)^{36}$.'

Als er in dergelijke situatie kinderen zijn, zijn zij de eerst aangewezene om zorg te verlenen. Ze moeten dat vanwege de scheiding van hun ouders op twee plekken, die ver uit elkaar kunnen liggen, gaan doen. Kortom, zowel de toegenomen individuele belasting als veranderende gezinsstructuren zouden volgens beleidsmakers bijdragen aan een afnemend zorgpotentieel en dat bij een toenemende zorgvraag.

Een afname van het informele zorgaanbod is een ontwikkeling die het streven naar meer en betere thuiszorg in gevaar brengt. Dat is gegeven her doel zorg in het nulde en eerste echelon te bevorderen natuurlijk ongewenst. Op zoek naar signalen dat dit meevalt, stellen beleidsmakers ook wel de vraag of een verdergaande individualisering werkelijk tot afname van zorgactviteiten leidt. 
'Vaak wordt geopperd dat door een ontwikkeling van de 'individualisering' er een afnemende bereidheid zou zijn onderling zorg te verlenen. Er zou een grotere onafhankelijkheid ten opzichte van het gezin en de familie ontstaan. Tegelijkertijd zouden de banden met vrienden, buren en collega's intensiever worden. Deze individualisering zou kunnen leiden tot meer hulp aan laatstgenoemden en minder hulp aan het gezin en de familie. Her is echter de vraag of uit de sociale contacten van gezinshuishoudens een dergelijke individualisering kan worden afgeleid ${ }^{37}$ '

Sommigen vinden het aannemelijk dat minder zorgverleners toch meer informele zorg bieden en baseren dit standpunt op het feit dat de jongere generatie zich weliswaar niet meer zo op familie en gezin richt dan voorheen, maar wel klaar zal staan voor het secundaire netwerk van buren, vrienden en collega's. Bovendien krijgt de jongere generatie meer vrije tijd en kan deze besteden aan het verlenen van informele zorg ${ }^{38}$. Naast de jongeren zouden ook de mannen een positieve invloed kunnen hebben op het zorgpotentieel. Zo zal het aantal jong-gepensioneerden toenemen. Dat kan betekenen dat een grote groep vitale mannen vrijkomt die voor een deel in te zetten is als informele verzorger. Bovendien zal de levensverwachting van mannen stïgen. Hierdoor daalt her verschil in levensverwachting tussen mannen en vrouwen van zes naar drie jaar en zullen er geleidelijk aan minder alleenstaande vrouwen komen. Aangezien het vooral (vrouwelijke) partners zijn die informele zorg bieden, zien beleidsmakers in de mannelijke helft van de bevolking extra zorgpotentieel. Tegenover een dalend zorgpotentieel als gevolg van veranderende gezinsstructuren schetsen beleidsmakers dus ook een mogelijk stijgende potentieel. Ze zijn ongerust, maar hoopvol gestemd.

Her is opvallend dat pas in een tijd dat beleidsmakers het zorgpotentieel betwijfelen, het persoonlijke karakter van informele zorg tot uitdrukking komt. Beleidsmakers spreken niet uitsluitend meer over nulde echelon, circuit of de informele zorg, maar noemen nu diegenen die zorg geven bij 'naam'. Zo gaat het bijvoorbeeld om partners, kinderen, vrienden, buren of collega's. Juist vanwege het mogelijke tekort aan verzorgers besteden beleidsmakers aandacht aan het type verwante dat aandeel in de zorg heeft en beschrijven ze bovendien hoe groot dat aandeel is.

Volgens beleidsmakers zijn her vooral familieleden en onder hen met name partners die informele zorg verlenen. Het merendeel van de zorgende partners is vrouw. Na de vrouwelijke partner geven kinderen de meeste zorg en onder de kinderen zijn dochters en schoondochters het meest acrief.

'Van oudsher zijn het voornamelijk (schoon)dochters, (schoon)zusters en moe-

ders die informele zorg verienen als andere mogelijkheden om in de hulpbehoefte te voorzien ontbreken. Ruim twee maal zoveel vrouwen als mannen 
bieden informele zorg. Het zijn veelal vrouwen zonder betaalde baan, met relatief lage opleiding en/of werkend in deeltijd-banen die mantelzorg verlenen. Verder zijn informele zorgverleensters vaak vrouwen van middelbare leefrijd of ouder ${ }^{39}$.'

Het problemariseren van het zorgaanbod gaat dus nier alleen samen met het inzichtelijk maken van actoren die zorg verlenen, maar maakt ook het sekse-specifieke karakter van informele zorg duidelijk.

Het aandeel van vrouwen in de zorg komt, zie ook bovenstaand citaat, tot uitdrukking wanneer beleidsmakers afzien van sekse-neutrale formuleringen of de 'mannelijke vormen' en vrouwelijke termen zoals 'zorgverleensters' gebruiken to. Dar de Emancipatieraad over 'zorgverleensters' schrijft is begrijpelijk. Als deze Raad een nota uitbrengt over thuiszorg en informele zorg heeft ze immers vanuit emancipatoir oogpunt belang om zorgarbeid van vrouwen onder de aandacht te brengen. Maar ook her, nier emancipatoire, zorgbelcid laat tegelijk met het problematiseren van het aantal zorgenden het sekse-specifieke karakter van zorg zien. Zo neemt het gebruik van woorden als vrouw, dochter of schoondochter ook in dat beleid toe.

'Vooral familieleden, in het bijzonder vrouwen, verschaffen veel meer hulp aan ouderen dan professionele medewerkers ${ }^{41}$.'

'Her is dan niet verwonderlijk dat uit een enquête blijkt dat ouderen wel door hun kinderen verzorgd willen worden maar dat zij deze zorg niet als een verplichting willen zien. Desondanks wordt deze zorg vaak wel geboden, in her bijzonder door dochters en schoondochters die elders wonen ${ }^{42}$.'

Dit gebeurt zeker als beleidsmakers erop wijzen dat mensen minder zorg gaan verlenen. In dat verband noemen ze het aandeel van vrouwen expliciet.

'Her aantal ouderen stijgt ten opzichte van het aantal vrouwen in middelbare leeftijdsklassen, die traditioneel voor ouderen zorgen. In de afgelopen vijftig jaar is de capaciteit voor informele zorg door dochters gehalveerd, dit zal komende vijftig jaar weer gebeuren ${ }^{43}$.'

'De toenemende arbeidsparticipatie van vrouwen heeft gevolgen voor de beschikbaarheid van de informele zorg. Vrouwen zullen steeds vaker zelf betaald werk hebben en minder vanzelfsprekend de verzorgende taken op zich nemen. Deze ontwikkeling onderstreept het belang van ondersteunende maatregelen voor het in stand houden van de informele zorg ${ }^{4}$.' 
Er zullen minder dochters worden geboren en steeds meer vrouwen van de nieuwe generatie zullen de arbeidsmarkt betreden. Beleidsmakers waarschuwen dat bij een verdere toetreding van vrouwen op de arbeidsmarkt in het jaar 2005 een tekort aan informele zorgverlening voor ouderen zal ontstaan ${ }^{45}$. De verwachte daling van verzorgers is voor een adequaat thuiszorgbeleid, aldus beleidsmakers, een belemmering. Dat vrouwen zorgtaken inruilen voor betaald werk buitenshuis verontrust beleidsmakers, in het kader van her thuiszorgbeleid, zeer.

Beleidsmakers leggen niet alleen een relatie tussen vrouwen en een afnemend zorgaanbod, maar ook tussen vrouwen en een toenemende zorgvraag. Zo zal de groep oudere vrouwen extra zorg moeten krijgen.

'Gezien de te verwachten stijging van juist het aantal alleenstaande bejaarde vrouwen met kanker, is er dus -hoewel voorspellingen hachelijk zijn- reden om rekening te houden met een groeiende behoefte aan vervangende vormen van thuiszorg ${ }^{46}$.'

'Wat betreft de huishoudsamenstelling kan worden opgemerkt dar mer name her percentage alleenwonende oudere vrouwen relatief hoog is (45\%) en mer de leefrijd nog toeneemt $(\ldots)^{47}$.'

'(...) zorgbehoevende, oudere, alleenstaande vrouwen vrijwel geen beroep kunnen doen op informele zorg, terwijl bij deze groep door de dubbele vergrijzing een duidelijk stijgende behoefte aan zorg en dienstverlening wordt geconstateerd " 1 .'

Beleidsmakers leggen dus zowel een verband tussen een afnemend zorgpotentieel en de rol van vrouwen hierin als tussen de toenemende zorgvraag en hun aandeel.

In reacrie op het vermeende zorgtekort en in het bijzonder op de verwachting dat vrouwen minder zorgen, verschijnen halverwege de jaren tachtig beleidsmaatregelen die ervoor moeten zorgen dat het huidige zorgpotentieel (minimaal) gewaarborgd blijft ${ }^{49}$. Vooral het toetreden van vrouwen tot de arbeidsmarkt zou her belang van ondersteunende maatregelen voor het in stand houden van de informele zorg onderstrepen. Aangezien het geven en ontvangen van informele zorg inmiddels gekoppeld zijn aan de vrouwelijke sekse, richt het beleid zich in eerste instantic op mannen "..

Zowel vanuit het emancipariebeleid als het ingezctte zorgbeleid bupleiten beleidsmakers dat mannen meer zorgtaken moeten verrichten ". De nadruk in het emancipatiebeleid staat grotendeels in teken van herverdeling van onberaald: arbeid russen de seksen of vergroting van zorgverantwoordelijkheid bij mannen. 
Het beleid gericht op stimulering van thuiszorg en informele zorg sluit hierbij aan. Op die manier zou niet alleen meer gelijkheid in het verlenen van zorgarbeid tussen de seksen worden gerealiseerd, maar heeft ook het extramuraliseringsbeleid meer kans van slagen ${ }^{52}$. De inzet van mannen bij zorgtaken zou de oplossing zijn voor een probleem dat door een tekort aan vrouwelijke verzorgers ontstaat.

Samenvattend definiëren beleidsmakers in de rweede periode informele zorg als zorg die in omvang afneemt. Dit heeft te maken met het inzicht dat vooral vrouwen zorg verlenen en de verwachting dat dit in de toekomst minder gebeurt. Dan zoeken beleidsmakers naar argumenten om aan te tonen dat het zorgpotentieel ook in de toekomst toereikend zal zijn en naar oplossingen om het mogelijk tekort aan verzorgsters, bij een toenemende vraag naar zorg, te minimaliseren. Dit komt vooral neer op het streven mannen meer zorgtaken te laten verrichten. Naar aanleiding van deze verandering in her denken over informele zorg stel ik de vraag of de politicke ongerustheid over een dalend zorgpotentieel ook in wetenschappelijk artikelen terug te vinden is?

\section{Veranderende sociale nerwerken}

Zowel het onderzoek gestart vanuit het medicaliseringsdebat als ook onderzoek gestart vanuit nieuwsgierigheid naar de gevolgen van het uiteenvallen van oorspronkelijke familie- en buurtnerwerken in kleine, mobiele gezinnen, resulteren in studies waarbij 'zorg voor elkaar' centraal staat. Leidt het uiteenvallen van grote gezinsverbanden tot eenzaamheid? Is dit een bedreiging zijn voor het welzijn, de gezondheid van mensen in het algemeen en van ouderen in het bijzonder? Leidt het uiteenvallen van gezinnen tor afname van zorgactiviteiten? Het 'natuurlijk ' of 'informeel' zorgsysteem is in de jaren tachtig door sociale wetenschappers als onderzoeksobject ontdekt.

De verandering in de samenstelling van sociale netwerken brengt sociologen en gerontologen in Amerika en Europa ertoe om gezinspatronen en de betekenis van familiebanden of netwerken in kaart te brengen. De aanname hierbij is dat leden van de 'nucleaire familie' van vóór de jaren zestig meer bereidwillig, warmer en behulpzamer geweest zouden zijn. Dit 'lieflijke' familietafereel lijkt vanaf de jaren zeventig mer de bouw van vele bejaardenhuizen, ziekenhuizen en verpleeginrichtingen te worden verstoord. De jonge generatie uit die tijd zou snel geneigd zijn ouderen in verzorginghuizen onder te brengen waardoor de professionele hulp het grootste aandeel in de zorg krijgt. Dit zou familieverantwoordelijkheden ondermijnen "3. Bovendien verwachten (ook) onderzoekers dat door veranderende gezinsstructuren het aanbod van informele zorg afneemt. Dit zou veroorzaakt 
worden door een daling van het gemiddelde aantal kinderen en doordat kinderen minder vaak dan vroeger in de nabijheid van hun ouders blijven wonen. Tot slor treden steeds meer vrouwen toe tot de arbeidsmarkt en deze tendens leidt ertoe dat vrouwen minder tijd hebben voor het geven van informele zorg. Evenals beleidsmakers betwijfelen onderzoekers de eens zo vanzelfsprekende zorg voor elkaar ${ }^{\text {s4. }}$.

Uit onderzoek blijkt echter dat ondanks de druk van de modernisering de zorg voor elkaar niet afneemt. Zo wijst het sociaal gerontologisch onderzoek in de Verenigde Staten uit dat de steun van gezin of familie daar nog steeds één van de belangrijkste factoren is bij het voorkomen van opname in een verpleeghuis"s. Verweduwing, alleen leven en kinderloosheid zijn predictoren vóór opname in een gezondheidszorginstelling. Het onderzoek maakt eveneens duidelijk dat partners en kinderen voor ouderen en zieken, ondanks tal van professionele instituten en veranderingen in leefstijl, nog steeds een waardevolle en aanzienlijke bron van hulp zijn. In Nederland is dar niet anders. In 30 procent van de ouder-kind relaties is (ook) sprake van een zorgrelatie ${ }^{56}$. Ook uit recentere studies blijkt dat mensen (tussen de 12 en 99 jaar) naast de normale huishoudelijke verzorging gemiddeld genomen vijf uur per week in de verzorging van een naaste investeren ". Zo zou $11 \%$ van de volwassen bevolking geregeld hulp bieden aan zieken of gehandicapten, $15 \%$ van de totale populatie vrouwen en $7 \%$ van de mannen ${ }^{58}$. Zouden we dit uitdrukken in geld dan schatten onderzoekers de economische waarde van informele zorg aan verwanten op to miljard gulden op jaarbasis ${ }^{9}$. Dergelijke bevindingen zetren dus vraagrekens bij de aanname dat de bereidheid tot het verlenen van informele zorg is afgenomen. Deze zou zelfs groter zijn dan 25 jaar geleden ${ }^{60}$.

Naast de vraag of mensen in deze tijd nog voor elkaar zorgen, vragen onderzoekers zich in toenemende mate af hoe die verwanten hun zorgtijd invullen. Ze verdelen zorg dan op in verschillende deel- of taakgebieden en dit opent mogelijkheid om antwoord te krijgen op de vragen wie-wanneer-welke taken op zich neemt. Dit type onderzoek maakt, veelal met behulp van voorgestructureerde vragenlijsten, de omvang van taken die eens als routinematige vanzelfsprekende huishoudelijke handelingen zijn bestempeld, inzichtelijk. Onderzoekers beschouwen zorg meer en meer als een individuele activiteit.

Dergelijke onderzoeken demonstreren dat zorg verlenen veelomvattend en arbeidsintensief is. Informele verzorgers doen bijvoorbeeld boodschappen voor (zieke) verwanten, wassen ze en kleden ze aan, helpen hen bij de financiën, koken hun maaltijden, helpen hen in en uit bed, regelen hun medicijnen, kopen kleding, repareren zaken in huis, houden zieken gezelschap. Dir geldr ook voor verzorgers van patiënten met terminale kanker ${ }^{61}$. Hoewel het type taken enigszins afhanke- 
lijk is van het type kanker, ontwikkelen verzorgers vaardigheden met betrekking tot: algemene dagelijkse levensverrichtingen, het verplaatsen van de patint, regelen van de stofwisseling/stoelgang, de toiletgang, het bieden van comfort, dieet en voeding, regelen van pijnmedicatie, wond en huidverzorging, het geven van injecties, het omgaan met een tube, uitzuigen van slijm, zuurstof verbruik en zorg voor de gewrichten ${ }^{62}$. Kortom: informele verzorgers ondersteunen zieken op tal van fronten ${ }^{63}$.

TABLE IV

Frequency in Which Management Skills Were Learned from a Formal Patient-Care Provider

\begin{tabular}{|c|c|c|c|c|c|c|}
\hline \multirow[b]{2}{*}{ Skill } & \multicolumn{2}{|c|}{ Patients } & \multicolumn{2}{|c|}{ Family \#1 } & \multicolumn{2}{|c|}{ Family \#2 } \\
\hline & No. & $\%$ & No. & $\%$ & No. & $\%$ \\
\hline $\begin{array}{l}\text { Activities of } \\
\text { daily living }\end{array}$ & $3 / 7$ & 43 & $3 / 7$ & 43 & $0 / 4$ & 0 \\
\hline Ambulation & $3 / 16$ & 19 & $3 / 16$ & 19 & $1 / 10$ & 10 \\
\hline $\begin{array}{l}\text { Bowel } \\
\text { management }\end{array}$ & $4 / 9$ & 44 & $4 / 9$ & 44 & $1 / 4$ & 25 \\
\hline $\begin{array}{l}\text { Bladder } \\
\text { management }\end{array}$ & $2 / 6$ & 33 & $3 / 6$ & 50 & $1 / 3$ & 33 \\
\hline Comfort care & $0 / 10$ & 0 & $0 / 10$ & 0 & $3 / 11$ & 27 \\
\hline Dietary care & $2 / 8$ & 25 & $2 / 8$ & 25 & $0 / 5$ & 0 \\
\hline $\begin{array}{l}\text { Pain } \\
\text { management }\end{array}$ & $3 / 9$ & 33 & $3 / 9$ & 33 & $0 / 5$ & 0 \\
\hline $\begin{array}{l}\text { Wound and } \\
\text { skin care }\end{array}$ & $2 / 9$ & 22 & $2 / 9$ & 22 & $2 / 9$ & 22 \\
\hline $\begin{array}{l}\text { Specialized } \\
\text { skilis }\end{array}$ & $2 / 3$ & 67 & $2 / 3$ & 67 & $8 / 9$ & 88 \\
\hline
\end{tabular}

Figuur 3: Voorbeeld uit onderzoek van Grobe (2981): verdeling van zorg in taken.

Dit type onderzoek maakt niet alleen het scala aan taken inzichrelijk, maar ook wie de taken verricht. In de meeste gevallen zijn dit partners van een zicke. Aangezien vrouwen gemiddeld langer leven is alleen vanuit dit gegeven de kans dat zij hun partner verzorgen al groter dan die voor mannen ${ }^{64}$. Dus de kans dat een zieke en/of stervende mannelijke partner een beroep doet op een vrouw is, alleen al vanwege verschillende levensverwachtingen, groter dan andersom omdat de meeste mannen (65.4\%) nog gehuwd zijn als ze ziek worden en overlijden, en de meeste vrouwen $(5 \mathrm{I}, 7 \%)$ verweduwd zijn op dat moment ${ }^{65}$. 
$\mathrm{Na}$ partners geven volwassen kinderen de meeste zorg. In de groep volwassen kinderen geven meer (schoon)dochters dan zonen hulp ${ }^{66}$. Dit zou niet alleen aan de rolopvatting en ijver van dochters toe te schrijven zijn, oudere en zieke mensen doen ook eerder beroep op dochters dan op zonen ${ }^{67}$. Bovendien zouden zonen eerder geneigd zijn fysiek en emotioneel afstand te nemen van zorgbehoevende ouders. Zij voelen zich minder schuldig dan dochters over het ongemak van hun ouders en accepteren eerder dat ze niet verantwoordelijk zijn voor het geluk van anderen ${ }^{68}$. Na de volwassen kinderen volgen nichten en tantes in de rij van zorgverleners. De hekkesluiters zijn buurvrouwen en vriendinnen ${ }^{69}$.

Speciale belangstelling binnen dit onderzoek bestaat yoor de groep vrouwen van middelbare leeftijd, ook wel 'de sandwich generation' of 'the women in the middle' genoemd. Deze vrouwen zouden door hun dubbele zorgtaak voor zowel hun kinderen als ouders in de verdrukking komen. Daarom zijn ze nier alleen belangwekkend voor sociologisch/gerontologisch onderzoek, maar ook voor onderzoek vanuit vrouwenstudies. Twee tegengestelde theoriën zijn bij dit onderzoek uitgangspunt (of conclusie). Sommige onderzoekers gaan ervan uit dat het vervullen van meerdere rollen door vrouwen een kwalijke invloed heeft op hun welzijn en gezondheid (scarcity-hypothese). Andere onderzoekers zien in het vervullen van meerdere rollen juist voordeel omdat het de (sociale en psychologische) positie van die vrouw verberert of versterkt (accumulatie-theorie). Hoe het ook zij: hun complexe zorgtaak, gekenmerkt door wisselende rollen, verschillende vaak onduidelijke verantwoordelijkheden, weinig waardering en een behoorlijke aanslag op her lichamelijke en psychologisch welbevinden, maakt deze groep verzorgsters voor onderzoekers extra interessant ${ }^{70}$.

Dankzij het onderzoek naar zorgtaken is duidelijk welke taken vrouwen en mannen verrichten. Vrouwen nemen de zorgrol makkelijker op zich omdat dit goed aansluit bij hun andere rollen, terwijl mannen nieuw gedrag moeten leren om een (succesvol) verzorger te zijn ${ }^{78}$. Mannen verrichten bijna geen zorgtaken waarbij ze lichamelijk intiem moeten zijn, zoals wassen, aan-en uitkleden en de toiletgang ${ }^{72}$. Een uitzondering hierop is de hulp aan de eigen partner. Alleen als her gaat om financiële of zakelijke werkzaamheden verschilt de bijdrage van zonen van die van dochters ${ }^{73}$. Mannelijke partners en zonen helpen bijvoorbeeld meer dan vrouwen en dochters met de financiële administratie en begrafenisaangelegenheden ${ }^{74}$. Van de vrouwen en mannen die voor iemand uit hun omgeving zorgen, besteden vrouwen daaraan meer rijd en nemen zij meer, maar ook een grotere diversiteit aan taken op zich ${ }^{75}$.

Anders dan in beleid maakt onderzoek echter ook gewag van verwachtingen over het geven van zorg die gebonden zijn aan sekse. Zo zouden professionele verzorgenden, en dit zijn ook meestal vrouwen, verschillende verwachtingen heb- 
ben van vrouwelijke en mannelijke informele verzorgers ${ }^{76}$. Als gevolg hiervan leggen ze verschillende maatstaven aan bij hun oordeel over hun inzer. De neiging bestaat van vrouwen meer zorgactiviteiten te verwachten dan van mannen ${ }^{77}$. Dit patroon manifesteert zich niet alleen bij informele verzorgers, maar ook bij mannelijke en vrouwelijke patiënten. Zo ontvangen alleenstaande oudere vrouwen bij overeenkomstige zorgbehoefte minder informele zorg dan alleenstaande (oudere) mannen ${ }^{78}$. Zij krijgen bij een zelfde zorgbehoefte significant minder hulp. Bovendien komen vrouwen later dan mannen voor opname in een verpleeghuis in aanmerking ${ }^{79}$. De actorgerichte benadering van zorg laat dus niet alleen zien dat vrouwen veel zorgen, maar ook dat zij bij gelijke behoefte minder professionele zorg ontvangen ${ }^{80}$.

Samengevat, gaan (ook) wetenschappers in de rweede periode uit van de veronderstelling dat er een tekort aan informele verzorgenden zal zijn. Dit vormt veelal de basis voor onderzoek naar 'sociale netwerken'. Ze onderzoeken deze veronderstelling en komen tot de conclusie dat ook in deze moderne tijd nog volop informele zorg wordt gegeven. Als dit is aangetoond verschuift het accent in het onderzoek. Nier alleen de vraag of er voldoende verzorgers zijn is aan de orde, maar eveneens de vragen wie de verzorgers zijn en wat ze precies doen. Het onderzoek naar informele zorg (bij patiënten met kanker) richt zich dan niet zo zeer meer op de groep verzorgers (grootte en invloed van familiaire netwerken), maar verschuift steeds meer richting individuele actoren. De partners van ouderen en zieken komen in beeld waarbij onderzoekers steevast verschil maken tussen de inbreng van vrouwen en mannen ${ }^{81}$.

Vergelijken we de conventies van beleidsmakers en wetenschappers over informele zorg in deze periode dan staat informele zorg zowel in het beleidsvertoog en het wetenschappelijk vertoog als waardevolle bijdrage voor de gezondheid van patiënten. Als het gaat om hun toekomstige omvang dan staan informele verzorgers in her beleidsvertoog voornamelijk te boek als een massa waarvan de omvang zal afnemen, in het wetenschappelijk vertoog worden verzorgers als cen immer aanwezige familie of sociaal nerwerk rond de patiënt beschreven. In beide vertogen zien we een accentverschuiving waarbij verzorgers eerst benaderd worden als een collectief (subsysteem of de familie), later komt de individuele (vrouwelijke) verzorger meer in beeld en wordt de relatie tot de zieke benoemd. Omdat beleidsmakers dan kunnen vrezen dat het volume vrouwelijke verzorgers daalt, sporen ze mannen aan meer bij de zorg betrokken te raken. Deze mogelijkheid ligt gezien de nadruk op het sekse-specifieke karakter van zorg voor de hand, maar is niet de enige manier. Welke andere maatregelen opperen beleidsmakers om geen zorgpotentieel te verliezen? 


\section{Partner en patiënt}

Zijn er genoeg burgers die zorg kunnen bieden? Deze vraag is inzet van beleid vanaf de jaren negentig. Aan de ene kant zijn er geruststellende signalen. Mannen en jong gepensioneerden vormen een nog aan te boren reservoir. Daar staat tegenover dat er meer vraag naar informele zorg komt en dar de verzorgers hun taak moeten combineren met andere taken zoals een baan buitenshuis. Juist omdat het zorgbeleid gebaseerd is op inspanningen van vrouwelijke informele verzorgers, stellen beleidsmakers maatregelen voor die mannen bij de zorg moeten betrekken. Dit is een manier het aantal verzorgers op peil te houden. De overheid lanceert echter ook andere plannen. Deze hebben niet zozeer het doel het aantal informele verzorgers te consolideren of te vergroten, maar hun dreigende overbelasting tegen te gaan ${ }^{{ }_{2}}$. Want, zo stellen beleidsmakers, pariënten worden vaak mer grote inzet en offers van de betrokkenen thuis verpleegd ${ }^{8_{3}}$. De mantelzorg is maximaal belast. Deze aanname vormt de beweegreden voor beleidsmakers advies ter ondersteuning van informeel verzorgenden uit te brengen ${ }^{\text {sh}}$. De ondersteunende maatregelen voor verzorgers die beleidsmakers voorstellen zijn divers. Het gaat bijvoorbeeld om het instellen van een vrije dag voor de informele verzorgers, telefonisch spreekuur en tal van deskundigheidsbevorderende activiteiten door professionele verzorgers ${ }^{{ }^{8}}$. Niet direct zichtbaar is dat beleidsmakers daarbij de (vrouwelijke) informele verzorger twee gezichten geven ${ }^{86}$.

Het eerste gezicht van de informele verzorger hoort bij het echolonnerings- en systeemdenken en is die van de informele verzorger als ware zij 'werknemer.' Dir gebeurt als beleidsmakers de nadruk leggen op hun mede-hulpverlenerschap of als beleidsmakers ze aanspreken als partners in de zorg. Ze beschouwen verzorgers dan als een wezenlijk onderdeel van het zorgsysteem. Het nieuwe gezicht is dat van de verzorger als 'patiënt'. In dit laatste geval gaan beleidsmakers ervan uit dat verzorgers zelf steun nodig hebben en dat hun draaglast groter is dan hun draagkracht.

Wie informele verzorgers vanuit het werknemers-perspektief benadert, bedeelt de informele verzorger kenmerken toe die bij werknemers horen en wel bij werknemers die op hen lijken. Beleidsmakers spiegelen informele verzorgers aan professioneel verzorgenden. Een kenmerk van de professional is dat deze scholing heeft genoten. Professionals hebben hierdoor kennis van zaken, en zijn specialist. In dit licht stellen beleidsmakers bijvoorbeeld voor dat informele verzorgers meer deskundigheid moeten krijgen. Ze veronderstellen dat informele verzorgers een kennistekort hebben, bijvoorbeeld over de ziekte, het ziekteverloop of de omgang met een zieke en dat ze zelf te veel moeite moeten doen om dit tekort te dichten. Beleidsmakers stellen voor om speciale cursussen of voorlichringsbijeenkomsten 
voor informele verzorgers te ontwikkelen. Op die manier kunnen professionals op vlotte wijze informatie aan informele verzorgers over dragen ${ }^{87}$. Thuiszorgorganisaties geven bijvoorbeeld al jaren de cursus 'ziekenver-zorging thuis'. Verzorgers leren hier over hulpmiddelen, tiltechnieken en andere praktische zaken die het geven van zorg makkelijker maken. Beleidsmakers moedigen dergelijke cursussen aan omdat dit informele verzorgers tot meer gelijkwaardige partners in de zorg maakt. ${ }^{88}$.

Als beleidsmakers het voorstel doen verzorgers financieel te ondersteunen beschouwen ze informele verzorgers ook als waren ze werknemers. Werkgevers belonen werknemers voor hetgeen zij doen. De voorgestelde financiële maatregelen voor informele verzorgers vallen in twee typen uiteen. De eerste maatregel komt tegemoet in gemaakte kosten. Zoals professionele verzorgers bepaalde kosten die gebonden zijn aan hun vak van de belasting mogen aftrekken, zouden voor verzorgers zorgkosten aftrekbaar moeten zijn. Hierbij valt te denken aan taxikosten van en naar de radiotherapie of kosten voor buitenshuis eten ${ }^{89}$. Beleidsmakers vormen informele verzorgers directer tot werknemers als ze voorstellen informele verzorgers, uit het cliënt-gebonden budget te betalen. Beide financieel ondersteunende beleidsmaatregelen worden geopperd ter verzachting van de gemaakte kosten die zorg thuis met zich meebrengt. Hoe dan ook willen beleidsmakers voorkomen dat financiële moeilijkheden thuis leiden tot opname. Daarbij zou een financiële incentive informele verzorgers ertoe kunnen aanzetten nog meer zorgactiviteiten op zich te nemen ${ }^{9 \circ}$.

Een laatste voorbeeld waaraan het beeld van de verzorger als ware het een werknemer ten grondslag ligt, is te vinden bij speciale coping-cursussen. Wie voor een lang zorgtraject staat zal stemmingswisselingen bij de zieke, rolconflicten bij zichzelf of andere moeilijkheden tegenkomen. Het lijkt beleidsmakers een goed idee cursussen op te zetten die informele verzorgers leren omgaan met deze nieuwe situatie. In Nederland zijn daartoe bijvoorbeeld zogenaamde RET-cursussen opgezet: 'de rationeel emotieve therapie'. In deze cursussen gaat het er kort gezegd om dat de informele verzorger een onderscheid leert maken in reële en irreële problemen. Irrële problemen zijn volgens deze theorie problemen die niet gebaseerd zijn op feiten, maar op verharde cognities. Als een verzorgster bijvoorbeeld vindt dat ze overdag altijd bij de zieke moer blijven, leert de cursus dit te beschouwen als een irreëel probleem, omdat het niet berust op feiten en een overdrijving inhoudt. Her gaat hierbij dus om cursussen waarbij coping-strategieën van informele verzorgers centraal staan en waarvan soortgelijke ook aan professionele hulpverleners worden aangeboden.

Beleidsmaatregelen die er vanuit gaan dat informele verzorgers medehulpverleners (en dus werknemers) zijn, kosten de overheid indirecr geld. Je zou kunnen 
zeggen dat er, hoewel geringe, herallocatie van betaling van zorg van professionele naar informele zorg plaats vindt. Dat wat zo kenmerkend is voor informele zorg, namelijk zorgarbeid die onbetaald plaatsvindt, heft her beleid op door verzorgers te betalen, bijvoorbeeld vanuit een cliënt-gebonden budget. Niet iedere beleidsmaker juicht deze maatregelen dan ook toe. Nog wordt er gewikt en gewogen of en hoe dergelijke maatregelen doorgang kunnen vinden.

Tegelijk lijken andere beleidsmaatregelen eenvoudiger te implementeren. Het betreft allerlei vormen van ondersteuning die de verzorger niet financieel, maar lichamelijk en psychisch moeten ontlasten. Deze taak delegeren beleidsmakers indirect aan professionals zoals psychologen of professionele verzorgenden. De verzorger stellen ze dan voor als iemand die hulp nodig heeft als ware het 'een pariën'.

'Thuiszorg is nict alleen steun aan hulpbehoevenden, maar ook een verlichting van de zorgtaken van partners, kinderen en anderen in de directe omgeving ".".

Want:

'Gebleken is dat mantelzorgers het langer volhouden als zij weten dat er aandacht is voor hun positie, bijvoorbeeld van professionele zorgverleners ${ }^{92}$.'

Wijkverpleegkundigen bijvoorbeeld zouden dus niet alieen meer aan de zorgvraag van patiënten tegemoet moeten komen, maar gaan ook in op hulpvragen van de informele verzorger. Het gaat hier bijvoorbeeld om dreigende overbelasting en emotionele uitputting ${ }^{33}$. Zo krijgen professionele zorgverleners bij wijze van spreken het verzoek hun cliëntenbestand uit te breiden. Zij moeten zich niet alleen meer richten op de patiënt maar ook op 'diens directe omgeving' tezamen 'het cliëntsysteem' genoemd ${ }^{94}$.

Beleidsmakers nemen ook andere initiatieven waarbij ze de informele verzorger als 'patiënt' benaderen. Zo stellen ze lotgenorencontact voor. Dergelijke steungroepen bieden een plaats waar lotgenoten terecht kunnen met vragen, geven erkenning en herkenning ${ }^{95}$. De veronderstelling is dat verzorgers hun problemen beter de baas kunnen als zij zich gesteund weten door andere verzorgers die in eenzelfde situatic verkeren.

Het beleidsvoorstel zorgverlof bij wet te regelen kan eveneens geinterpreteerd worden vanuit het idee dat informele verzorgers patiënten zijn. Dit verlof kan helpen dubbele taken en daarmee lichamelijk, psychisch en sociaal lijden te voorkomen dan wel te verlichten. Bovendien geeft het mogelijkheid meer mannen bij zorgverleningsprocessen te betrekken ${ }^{96}$. Het gaat er in ieder geval vanuit dat verzorgers onvoldoende draagkracht hebben om in combinatie met een baan te zorgen. 
De aansporing tor bovenstaande maatregelen noemt men in beleidstermen het bevorderen van flankerend beleid. Dat betekent in dit verband kortweg dat beleidsmakers lijnen uitzetten om het zorgbeleid te kunnen handhaven. Steun aan verzorgers flankeert de extramuralisatie van zorg. Want door ondersteuning bij zorgtaken van informele verzorgers zal de zorglast verminderen, de draagkracht toenemen waardoor het informele-zorgbeleid gehandhaafd kan blijven. Implicier verschuift echter de conventie over de aard van informele verzorgers. Was zij eerder nog een waardevolle kracht binnen het zorgsysteem, nu zou ze ook zelf steun behoeven ${ }^{97}$. Dit wordt wel geduid als 'de Januskop van de informele zorg' ${ }^{98}$. De verzorger is volgens beleidsmakers 'werknemer' en 'patiënt' tegelijk.

'Hun bijdrage kan klein beginnen, maar in de loop van de tijd grotere vormen aannemen en langer duren dan ze verwacht hadden. $\mathrm{Zij}$ krijgen geen gelegenheid om uit te rusten of op vakantie te gaan, want er is niemand aan wie ze hun taak over kunnen dragen. Zo teren mensen in op hun reserves. Ze twijfelen of ze het wel goed doen en krijgen last van schuldgevoelens als ze merken dat ze het niet meer op kunnen brengen. Personen, die lange tijd vrijwillig voor iemand zorgen, verliezen het uitzicht op hun eigen toekomst. Ze maken geen plannen meer, omdat ze nier meer weten wanneer ze die uir kunnen voeren. Her gevolg: zij komen in hun eigen leven in de problemen bijvoorbeeld op hun werk of met hun partner ${ }^{9 \%}$ '

Samengevat richten beleidsmakers zich in derde periode niet alleen meer op de vraag hoe het collectief verzorgers in stand blijft, maar steeds meer op de vraag hoe de individuele informele verzorger zoveel mogelijk gesteund kan worden. Dit gebeurt bijvoorbeeld door meer bekendheid te geven an informele zorg en aandacht te besteden aan deskundigheidsbevordering ${ }^{100}$. Ze opperen verschillende maatregelen. Deze vallen uiteen in maatregelen waarbij het beleid de verzorger als ware het een werknemer beschouwt en maatregelen die uirgaan van de verzorgers als patiënt. In het ene geval moeten verzorgers zelf veranderen, in het andere geval niet en krijgen ze steun van de professionals. In de derde periode staan informele verzorgers in het beleidsvertoog dus voor 'werknemer' ofwel de partner van de professional én voor hun 'patiënt'. In de volgende paragraaf zal ik nagaan of in de wetenschappelijke praktijk de informele verzorger eveneens twee gezichten krijgt. 


\section{Ondersteun verzorgers}

De actorbenadering van zorg richt zich aanvankelijk vooral op de omvang van de zorgarbeid. Uit welke raken bestaat zorgarbeid en wie verricht die taken? Vanaf de jaren rachtig produceren wetenschappers cijfers, tabellen en statistieken over de omvang van zorgarbeid. Hiermee maken onderzoekers duidelijk welke krachten het familienetwerk aanboort om zieken te ondersteunen.

Midden jaren tachtig, ontstaat met name in Angelsaksische landen ook onderzoek, gevoed door feministische ideeën uit die tijd ${ }^{10}$. Hierin staat niet zozeer de omvang van de zorgarbeid centraal, maar meer de ervaringen van verzorgsters en in her bijzonder hun wensen en noden ${ }^{102}$. Onderzoekers uit deze stroming hebben kritiek op hun collega's omdat deze het zorgbeleid dat volgens hen stoelt op de idee dat de positie van vrouwen onveranderlijk is, niet kritisch beschouwen. Teveel onderzoekers gaan in hun ogen uit van het idee dat vrouwen zorgen en dat met of zonder steun blijven doen. Deze onderzoekers slaan volgens de critici de plank mis, want steeds meer vrouwen zullen naast zorgtaken ook betaalde arbeid verrichten. Een zorgbeleid dat vrouwen automatisch definieert als "het reserveleger van de sociale politiek' vraagt om een serieuze herbeschouwing en hieraan willen deze onderzoekers een bijdrage leveren. Anders gezegd:

'The primary goal of researchers should be to attempt to understand the experiences of caregivers and to help to articulate their concerns, rather than to seek to manipulate family members in pursuit of economic efficiency ${ }^{\text {tos. }}$.

Dergelijke kritieken zijn mede aanleiding om andere onderzoeksvragen te stellen. Hoe past zorg in het leven van vrouwen en mannen? Welke betekenis geven mannen en vrouwen aan zorg? Waar liggen de grenzen van zorgarbeid? Het onderzoekslicht schijnt daardoor niet alleen meer op de zieke met daaromheen de familie als omgevingsfactor, zoals in het eerdere onderzoek nog het geval was, maar verplaatst zich langzaam naar de informele hulpverleners ${ }^{104}$.

Onderzock waarbij ervaringen van informele verzorgers op de voorgrond staan, toont dat de moticven waarom zij zorgen divers zijn. Verwantschaps plicht, liefde. of altruïsme kunnen de basis zijn voor zorgarbeid. Wederkerigheid zou eveneens belangrijk zijn. Verzorgers zouden een relatie aangaan waarin zij zichzelf nodig, nurrig en produktief vinden ${ }^{105}$. Sommige verzorgers vinden her daarbij boeiend nieuwe vaardigheden te leren. Dit kan gaan om de verzorging van de zieke, maar ook om algemene huishoudelijke vaardigheden. Mannelijke verzorgers leren bijvoorbeeld koken ${ }^{106}$. Toch is er niet één reden of argument te geven waarom een mens voor een ander zorgt ${ }^{107}$. Iedere zorgrelatie fuctueert tussen gevoelens van aantrekken tot afstoren, van verplichting tot losmaken, van liefde tot haat en 
onverschilligheid. Juist dit brede spectrum van wisselende, ambivalente emoties met bijbehorend gedrag is kenmerkend voor zu'n relatie.

Her onderzoek maakr ook duidelijk dat her geven van zorg geen sinecure is. Veel informele verzorgers belanden in een crisis. Zo ondervinden verzorgers bijvoorbeeld stress in relatie tot het geven van zorg, stress in hun relatie tot de zieke en in relatie tot hun sociale netwerk ${ }^{108}$. Verzorgers kiezen er zelden expliciet voor een zorgrelatie aan te gaan. Dit zou eerder een geleidelijk en ondoorzichtig proces zijn. Stapje voor stapje neemt de zorgvraag toe en verschuift de verzorgster haar grenzen ${ }^{109}$. Zo wordt de verzorgster een 'gevangene der liefde'. Wat begint uit genegenheid, wordt sluipenderwijs een dagelijkse plicht die moeilijk een halt toe te roepen is. Andere onderzoekers beschouwen stress en crisis niet zozeer als uitkomst van zorg, zij wijzen een directe oorzaak-gevolg relatie af. $\mathrm{Zij}$ stellen dat een zorgrelatie, juist omdat daarin spanningen evident zijn en deze wisselende gevoelens oproepen, altijd stress in zich draagt ${ }^{10}$.

Voor veel informele verzorgers neemt de hulpbereidheid af naarmate de zorg langer duurt en intensiever is "'. De zorgbelasting is dan zo groot dat het lichamelijke uitputring, psychische en sociale klachren en/of financiële problemen tor gevolg heeft. Onderzoekers spreken zelfs van 'burn-out' bij informele verzorgers "12. Met deze term refereren ze aan een klachtenpatroon dat artsen meestal in verband brengen met klachten van werknemers. Een gevolg van de zogenaamde burn-out van verzorgers is dat verzorgers in vergelijking tot niet-zorgers twee tot drie keer zo vaak anti-depressiva gebruiken. Verzorgers uiten namelijk vaker psychische klachten zoals depressiviteit en slapeloosheid. Bovendien zijn chronische vermoeidheid, kwaadheid, ruzies, en sociale isolatie ook belangrijke gevolgen van een langdurige zorgrelatie "s.

Hoewel niet alle onderzoekers tot een zelfde conclusie komen zijn er aanwijzingen dat vrouwelijke verzorgers zich minder prettig bij zorgverlening voelen dan mannen en meer psycho-somatische klachten uiten ${ }^{{ }^{14}}$. Dit zou onder andere komen omdat vrouwen zorgrelaties aangaan vanuit een sociaal bepaald plichtsgevoel, terwijl mannen eerder zorgen vanuit genegenheid of affectie "s. Wie zorg beschouwt als plicht en dus extrinsiek gemotiveerd is, heeft eerder grenzen bereikt. Wie zorg beschouwt als neventaak of hobby en zo dus intrinsieke motivatie opbrengt, kent meer reserves. Bovendien, krijgen mannen voor hun zorgarbeid meer waardering van derden ${ }^{116}$. Verzorgers, zo vertelt ons dit onderzoek, beleven genoegen aan her zorgen, maar ondervinden ook moeilijkheden. Vrouwen lijden relarief meer onder het geven van zorgarbeid dan mannen.

Zorg verlenen is belastend. In het verlengde van deze bevinding gaat men ook de behoefte aan steun bij verzorgers onderzoeken. Verzorgers zouden op de eerste plaats behoefte aan informatie hebben, van een simpel wie is wie tot een gevari- 
eerde opsomming van uiringen van de ziekte en de mogelijke behandelingen van hun naaste. Ten tweede gaat het om behoefte aan vaardigheidstrainingen, vooral de verpleegkundige technische vaardigheden alsook het omgaan met incontinentie of tiltechnieken etc. Ten derde zou het om behoefte aan emotionele steun gaan. Hierbij valt te denken aan waardering voor het werk dat verzorgers verzetten, iemand hebben om mee te praten, hulp bij het herkennen van en omgaan met tal van emoties zoals schuld, angst, depressie en hopeloosheid. Ook hebben verzorgers behoefte om te leren hoe ze grenzen kunnen stellen aan hun werk of zouden ze willen leren te onderhandelen met de zieke. Tot slot wensen verzorgers enig respijt van hun rol. In de wetenschappelijke literatuur bestaat opvallend veel consensus over de vraag wat verzorgers nodig hebben ${ }^{117}$.

Als dergelijke vormen van steun in de prakrijk zijn gebracht, bepalen sommige onderzoekers vervolgens de effecten hiervan. Zo is men het rendement van een terugkerende 'vrije dag' bij informele zorgers nagegaan ${ }^{\text {n\& }}$. De onderzoekers formeerden een groep verzorgers, die wel geregeld vrijaf kregen en een controlegroep die dat niet kreeg en concludeerden dat een terugkerende vrije dag de gezondheid van verzorgers ten goede komt en dit bovendien de kwaliteit van de relatie met de verzorgde verhoogt.

Opvallend is dat de meest recente wetenschappelijke literatuur over verzorgers 'het zorgen voor' vooral in termen van moeilijkheden, lijden, opbranden en stress definieert en beoordeelt ${ }^{119}$. Hoewel er aandacht blijft voor andere ervaringen van informele verzorgers, gaar relatief veel aandacht uit naar de minder aangename kanten van zorgarbeid. 'Dependent care, caregiver burden, and self-care agency of spouse caregivers, 'The family with cancer', 'Identifying the needs of Home Caregivers of Patient with Cancer', zijn enkele voorbeelden van titels die de teneur van het onderzoek, in deze periode, aangeven. De (engelstalige) literatuur van de laatste jaren over stress en uitputting bij informele verzorgers (bij patiënten met kanker) is omvangrijk ${ }^{120}$.

Samengevat definieerr de werenschappelijke wereld het zorgverlenen in toenemende mate als een belastende activiteit. Hoewel dit het voordeel heeft dat onderzoekers het werk van verzorgers serieus nemen, heeft her als gevolg dat verzorgers vooral als de 'achilleshiel' van het zorgsysteem worden beschouwd ${ }^{12}$. Onderzoeksvragen gaan vooral over de kwersbaarheid van de hiel, de belasting ervan en op welke wijze men deze kan ontlasten ${ }^{12}$. De aandacht richt zich vooral op zorg als een voor de persoon, meestal een vrouw, stressvolle situatie. In het wetenschappelijk vertoog staat de informele verzorgster steeds meer gelijk aan 'een patiënt'.

Vergelijken we het beleidsvertoog met het wetenschappelijk vertoog, dan herbergt het beleidsvertoog in deze laatste periode twee conventies over verzorgers en domineert er in de wetenschap één. In het beleid staat de verzorger voor werkne- 
mer en patiënt. In de wetenschap rreedt de verzorger als patiënt steeds meer op de voorgrond.

\section{Zwakke zorgenden}

Conventies in beleid over informele verzorgers zijn verschoven. Werd informele zorg eerst beschreven vanuit een systeemperspectief, later gebeurt dit vanuit het perspectief van de (vrouwelijke) actor om vandaag de dag uit te gaan van een (vrouwelijke) overbelaste actor in beleid. In de eerste periode stellen beleidsmakers informele zorg voor als een collectief, een systeem binnen de gezondheidszorg. De nadruk in de beschrijving van informele zorg ligt in die periode vooral op de betekenis van dit collectief voor anderen. Deze is groot. Volgens beleidsmakers zou dit systeem er bijvoorbeeld voor zorgen dat de kwantiteit van zorg binnen het totale zorgsysteem gehandhaafd kon blijven. Bovendien zou het de kwaliteit van leven van patiënten ten goede komen. Kortom: beleidsmakers benadrukken in de eerste periode de kracht van het collectief verzorgers voor de totale gezondheidszorg.

In de tweede periode beschrijven beleidsmakers informele zorg nier alleen meer vanuit een systeemperspectief. Het actorperspectief krijgt ingang. Deze verandering komt bijvoorbeeld tot uiting door het taalgebruik. Zo gebruiken beleidsmakers synoniemen voor informele zorg die het sociale karakter van die zorg aangeven. Staat informele zorg in het zorgbeleid aanvankelijk synoniem voor 'nulde lijn', 'de mantelzorg' of 'het informeel zorgcircuit', in deze periode staat het voor 'partners', 'kinderen' en 'dochters'. Door her benoemen van de relatie van de verzorger tor de zieke breken beleidsmakers het zorgsysteem (of de nulde lijn) als het ware open; het systeem gaat leven. Ze laten ons kennis maken met diegenen die het informele zorgcircuit bemensen. Dit zijn in hoofdzaak vrouwen. Kortom: beleidsmakers maken ons in de tweede periode duidelijk dat vrouwelijke partners en dochters een waardevolle bijdrage leveren aan het welzijn en de gezondheid van pariënten.

In de derde periode schrijven beleidsmakers niet alleen meer over de belangrijke bijdrage van de (vrouwelijke) actor voor het gezondheidszorgsysteem en het welzijn van de patiënt, maar richten ze ook de aandacht op de lasten die het verzorgen met zich meebrengt. Ze benadrukken dat zorgen zware arbeid is en trachten de arbeidskrachten te behouden door ze verschillende vormen van steun aan te bieden. Nu definiëren beleidsmakers verzorgers als waren zij werknenners en patiënt tegelijk. Kortom: naast de kracht van verzorgers voor het zorgsysteem en 
de patiënt, komt de zwakte van de individuele verzorger in de derde beleidsperiode steeds meer op de voorgrond te staan.

Aan de verschuiving van het systeem-, naar het actorperspectief ligt de vraag ten grondslag of het collectief zorgenden wel toereikend zou zijn. Dit is weliswaar een vraag die bij de systeemopvatting past, maar om deze vraag te beantwoorden is het nodig het informele zorgsysteem open te breken. Zoals gezegd rransformeren beleidsmakers het informeel zorgsysteem in individuele actoren en dar blijken vooral vrouwen te zijn. Aangezien beleidsmakers vrezen dat zij zorgarbeid zullen inruilen voor betaalde arbeid, veronderstellen ze een afname van het zorgpotentieel. Niet alleen trekken ze het voortbestaan van het collectief verzorgenden in twijfel, ook de tekortschietende individuele draagkracht van verzorgers brengen beleidsmakers dan steeds meer onder de aandacht. Mer andere woorden: op het moment beleidsmakers de sterkte van het zorgcollectief benoemen gebruiken ze daarvoor sekse-neutrale (systeem)terminologie. Wanneer echter de noden van verzorgers, zowel in kwantitatief als kwalitatief opzicht, een beleidsissue zijn, is de relatie met vrouwen expliciet. Mannen kunnen dan een uirkomst bieden.

De verschillende conventies vervangen elkaar natuurlijk niet volledig. Ze komen naast elkaar voor. Er is eerder sprake van een accentverschuiving in de definiëring van informele zorg. Deze subtiele verschuiving, zo liet de analyse zien, gebeurt niet alleen in beleid. Hoewel er verschillen tussen beleid en wetenschap aan te geven zijn, is ook in wetenschappelijke teksten een soortgelijke verschuiving zichtbaar. Wetenschappers spreken bijvoorbeeld eerst over een 'secundair netwerk', of 'de sociale omgeving'. Ze roemen de hoeveelheid zorg die dit netwerk biedt. In de tweede periode koppelen ook de wetenschappers zorgactiviteiten aan personen. Ze vragen zich af wie er zorgt en welke activiteiten ze uitvoeren. Partners, dochters en schoondochters blijken veel zorgtaken op zich te nemen. $\mathrm{Zij}$ vormen dan het object van onderzoek. Als de hoeveelheid activiteiten die deze verzorgers verrichten in kaart is gebracht, krijgen wetenschappers meer aandacht voor de individuele actor die zorg geeft. Ze vragen naar de ervaring van verzorgers en als deze niet onverdeeld positief blijkr, meten ze bijvoorbeeld hun belasting. Deze is, evenals bij andere vormen van arbeid, groot. Om de belasting te verkleinen, dragen wetenschappers oplossingen aan, waarvan ze vervolgens de effecten meten. In de laarste periode overheerst in de wetenschap de conventie dat een verzorgster zware arbeid verricht en dat ze daarvoor onvoldoende draagkracht heeft.

Conventies in beleid en wetenschap verschuiven dus subtiel van 'systeem', naar 'werknemer' naar 'zieke werknemer'. Anders gezegd: de vertogen delen ze in dit opzicht een denkstijl. Ze versterken elkaars vertelling. En doordat deze beide krachtige vertelinstanties de zwakte van verzorgsters benadrukken, ze beschouwen 
als overbelaste mensen, is dat in de jaren negentig een tamelijk dominant verhaal.

Beleidsconventies over informele verzorgers zijn dus verschoven van een informeel zorgsysteem als krachtig onderdeel van en voor het gezondheidszorgsysteem naar partners of dochters, die door her uirvoeren van tal van acriviteiten bijdragen aan zorg voor zieken, naar vrouwen die in kwantitatief opzicht onvoldoende kunnen bijdragen en bovendien overbelast zijn. Wat betekent deze verschuiving voor de verzorgers?

Op de eerste plaats legt het beleid met het benoemen en ontstaan van informele zorg als een specifiek onderdeel van het gezondheidszorgsysteem de verantwoordelijkheid voor zorg expliciet bij informele verzorgers. Het feit dat dit vooral vrouwen zijn is daarbij aanvankelijk geen issue. Later vermelden beleidsmakers echter wel het grote aantal vrouwelijke verzorgers. Dit staat in verband met het dreigend tekort aan informele verzorgers. Vrouwenemancipatie, en de toenemende participatie van vrouwen op de arbeidsmarkt, leiden ertoe dat het extramuraliseringsbeleid onder druk komt te staan. Beleidsmakers verwachten dat werkende vrouwen minder tijd hebben voor zieke partners en verwanten. Vrouwenemancipatie is dus een obstakel voor het slagen van het informele zorgbeleid. Anders gezegd, voor zover in beleid het geseksueerde karakter van zorg tot uitdrukking komt, gebeurt dit door de levensloop van vrouwen en keuzes die zij maken ten aanzien van werk en carrière als maatschappelijk probleem te definiëren.

Op de tweede plaats beschrijven beleidsmakers de aard van het werk van verzorgers op typische wijze. Zodra zorgen als zware arbeid wordt erkend, definiëren beleidsmakers verzorgers in toenemende mate als wezens die te weinig draagkracht bezitten. Zij worden geacht meer kennis over zorg tot zich te nemen, cursussen te volgen om hun draagkracht groter te maken en bij tijd en wijle afstand te nemen van de verzorgde opdat ze hun zorgtaak kunnen volbrengen. Hoewel dat op individueel niveau nutrige interventies kunnen zijn, belicht het beleidsdebat hiermee vooral tekortkomingen van verzorgers. Daardoor zijn de lasten in het huidige beleid meer zichtbaar dan de lusten en komt de kwetsbaarheid van de verzorgers op de voorgrond te staan. Bovendien sneeuwt her de kansen die het verlenen van zorg biedt onder ${ }^{123}$. Mer andere woorden; deze gender-subrekst laar zien dat beleidsmakers (de draag) kracht van (vrouwelijke) verzorgers in toenemende mare problematiseren. Hoewel het wetenschappelijk vertoog bijvoorbeeld een alternatieve vertelling biedt voor het krimpend zorgpotentieel, versterken de vertogen elkaar. Dit is enigszins begrijpelijk, want wetenschappers dragen zelfs expliciet bij aan het informele-zorgbeleid en beleidsmakers vragen om wetenschappelijke inbreng. Naarmate denkstijlen en conventies tussen beleid en wetenschap meer overeenkomen des te beter, effectiever of directer zou beleid zelfs 
gebruik kunnen maken van werenschap (en vice versa) ${ }^{24}$. Deze verstrengeling van beleid en werenschap is echter precies de kritiek van sommige beleidsanalisten. Zo is vanuit vrouwenstudies de manier waarop veel onderzoekers hun onderzoek naar informele zorg vorm geven bekritiseerd. Volgens hen beschouwt het gangbare onderzoek zorg als arbeid; een optelling van taken. Onderzoekers inventariseren de taken, precieze activiteiten en de daarmee gemoeid zijnde uren, maar verzuimen in te gaan op het sociaal-emotionele aspect van zorg. Maar ook vanuit de beleidswetenschap is er kritiek op het meer gangbare onderzoek ${ }^{125}$. Men stelt bijvoorbeeld dat veel onderzoek een te bureaucratische inslag kent, omdat beleidsmakers onbedoeld bepalen welke criteria worden aangelegd ter beoordeling van beleid. Wetenschappers zouden zich (vaak impliciet) te zeer aan het beleid conformeren en daardoor kent veel onderzoek een 'managementbias' of 'beleidsbias' ${ }^{126}$. In dat licht is in het kader van dit onderzoek te concluderen, dat onderzoekers die bijvoorbeeld maatregelen voorstellen om informele verzorgers te steunen of die effecten van deze maatregelen meten zich impliciet (en. wellicht onbedoeld) committeren aan een beleid dat het geven van informele zorg steeds meer als een plicht definieert. Zij nemen nier her informele zorgbeleid onder de loep, maar het gedrag van verzorgers.

Juist omdat beleidsmakers en wetenschappers conventies, vocabulaires en denkstijlen over informele zorg op hoofdlijnen delen, zal ik in de volgende hoofdstukken een ander tegenverhaal introduceren. Her verhaal van de informele verzorgers (zelf). 


\section{Thuis}

Toen mijn zoon bedlegerig werd, heeft hij eerst een tijdje op zijn eigen bed gelegen, maar dat was te laag. Daarom hebben we hem op een ziekenhuisbed gelegd. Hij kon in die tijd alleen maar op zijn rug liggen. We waren natuurlijk heel bang dat hij zou gaan doorliggen dus hebben we een waterbed genomen. Maar hij bewoog amper en lag constant in hetzelfde bed. Helaas hebben we het doorliggen niet kunnen voorkomen.

Naast mij, mijn man en de kinderen, waren er heel veel mensen die graag voor hem wilden zorgen. Mijn zussen, de overbuurvrouw, mijn broer en schoonzus en zijn schooliuffrouw. Ze wilden allemaal met plezier wat voor hem doen. En ik wilde graag zorg uit handen geven. Ik ben immers niet de enige die voor hem wat betekenen kan. Eigenlijk zijn we er steeds vanuit gegaan dat je niets vast mag houden zelfs je eigen kind niet. Zo kwam het dat hij regelmatig uit logeren ging.

Als bij naar de overburen ging zetten we hem in een rolstoel, hij lag daar beneden op een bed. Ook ging hij geregeld naar mijn broer. Daar hebben ze behalve een waterbed een groot bad. Heerlijk vond hij dat. Mijn zus heeft een suembad in de tuin. Dat was helemaal fantastisch. Wat hij bij ons al niet meer kon, lukte in dat zuembad nog wel. Hij liep.

Op bet moment dat hij naar die mensen toe ging, ging hij echt wit logeren. Hij wilde helemaal vrij zijn en zei dan: 'Mam ik ga uit, je mag niet komen, hoor.'

Uit een interview van een moeder die voor haar zoon zargde. 


\section{Verborgen Verzorgers}

\section{Inleiding}

In het vorige hoofdstuk heb ik duidelijk willen maken dat beleidsmakers de verantwoordelijkheid voor zorg in hoofdzaak bij vrouwen leggen. Omdat zij er vanuir gaan dat vrouwen die de arbeidsmarkt betreden: minder beschikbaar zijn voor zorg, definiëren ze hun betaalde arbeid als probleem. Bovendien besteden beleidsmakers aan de onvolkomenheden in de zorgarbeid (van vrouwen) meer aandacht dan aan datgene dat (al jarenlang) goed gaat, waardoor ook en vooral het problematische karakter van informele zorg in de schijnwerpers komt. Kortom: hoewel beleidsmakers buitenshuis werken van vrouwen en hun zorgarbeid aanmoedigen, problematiseren ze het de laatste jaren evenzeer.

Dat beleidsmakers kritisch zijn over de rol van vrouwen is gegeven het beleidsdoel thuiszorg te stimuleren niet zo vreemd. De aanwezigheid en inzet van informele verzorgsters zijn belangrijke voorwaarden om mensen thuis te laten sterven. Bovendien zouden verzorgsters garant staan voor een goedkopere gezondheidszorg, zouden ze zelfstandigheidsverlies van patiënten voorkomen en zouden juist zij tegemoet komen aan wensen van patiënten. Beleidsmakers veronderstellen dat informele verzorgers van cruciaal belang zijn om het thuiszorgbeleid te laten slagen. Alleen dankzij hun inzet kunnen de beleidsdoelen worden gehaald.

Naast de noodzakelijke inzet van verzorgers rust dit beleid op twee andere peilers. Zo geven beleidsmakers ook de patiënt een belangrijke rol. Diens wens thuis te zijn is bijvoorbeeld een belangrijk argument thuiszorg en informele zorg te stimuleren. Hoewel de cijfers laten zien dat ongeveer driekwart van de patiënten met kanker in een ziekenhuis overlijdt, waarbij een groot deel van de doodzieke mensen hun eigen huis pas verlaat als het mis dreigt te lopen, bouwt het beleid vooral op de situatie zoals de patiënt die wenst ${ }^{1}$. Daarbij veronderstellen beleidsmakers dat thuis de meest ideale verzorgingsplek is. Het huis heeft in vergelijking met het ziekenhuis voordelen zoals het behoud van autonomie, het biedt comfort en veiligheid. Kortom: in het thuiszorgbeleid staan naast de verzorger, de pariënt en her huis centraal.

In dit hoofdstuk zal ik deze laatstgenoemde peilers nader onder de loep nemen. I $\mathrm{k}$ zal nagaan welke patiënten beleidsmakers in beleidsteksten construeren en deze vergelijken met die van verzorgers. Welke wensen heeft de patiënt volgens beleidsmakers? Wat karakteriseert hem/haar? En hoe verhoudt de patiënt zich tot de verzorger? Daarna zal ik beschrijven hoe het huis in beleid naar voren komt en 
dat vergelijk ik eveneens met het beeld dat verzorgers hiervan geven. Wat maakt het huis volgens beleidsmakers tor een plezierig oord? Welke eisen stellen ze aan het huis? En waarin verschilt het van intramurale instellingen? Door de vergelijking van vertogen kan ik laten zien welke gevolgen de beleidsbeschrijving van de patiënt en het huis heeft voor verzorgers. Anders gezegd welke gender-conventie het beleid in dit verband produceert.

\section{De patiënt kiest}

Wie ziek is kan op verschillende locaties worden verzorgd en wie weet aan kanker te zullen sterven kan dat ook op verschillende plaatsen doen. In Nederland onderscheiden beleidsmakers intra- en extramurale zorg. Intramurale instituten, zoals ziekenhuizen, verpleeghuizen of verzorgingshuizen kenmerken zich door het feit dat ze 24-uurs professionele zorg garanderen en dat de zorgverlening binnen de muren van een speciaal daarvoor bestemd en ingericht instituut plaatsvindt. Extramurale zorg kenmerkt zich door her intermitterende karakter van professionele zorg die geboden wordt in de persoonlijke levenssfeer van de patiënt.

Volgens beleidsmakers zouden de meeste burgers thuis willen sterven, maar laten stervende mensen zich vaak nog opnemen in intramurale instellingen uit angst voor de dood. Het kan ook zijn dat professionele en informele verzorgenden de patiënt niets willen onthouden. Dit noemen beleidsmakers 'overbodige medicalisering ' ${ }^{2}$. Zorgverleners in ziekenhuizen voelen zich, onder druk van patiënt en familie, vaak nog verplicht in te grijpen, terwijl al vast staat dat het tevergeefs is. Een goede organisatie van thuiszorg, stervensbegeleiding thuis, meer aandacht voor palliatieve zorg en de opkomst van hospices zouden een tegenwicht moeten bieden. Deze alternatieven zouden een waardig levenseinde in de eigen leefomgeving mogelijk maken en bovenal meer aan wensen van mensen voldoen.

Verreweg de meeste mensen geven er ook zelf de voorkeur aan zo lang mogelijk thuis te kunnen blijven, of, bij ziekenhuisopname, weer zo snel mogelijk naar huis terug te keren. Het beleid dat zich richt op extramuralisering is gebaseerd op voorkeur van mensen zelf?'

Volgens beleidsmakers willen mensen als het kan thuis sterven. Ze definiëren thuis(verzorging) dus als een intens verlangen, een ultieme wens van mensen.

'In plaats van opname in een verzorgingshuis verkiest men veelal langer thuis te blijven $(\ldots)^{4}$.' 
'Wat betreft de laatste levensfase: mensen willen het liefst in hun eigen bed sterven $(\ldots)^{\text {s.' }}$

'Te verwachten valt dat het aantal mensen dat thuis wil overlijden zal toenemen en dus ook de vraag naar terminale thuiszorg.'

Bij nader inzien gaat het echter niet om alle mensen, maar zijn het patiënten die thuiszorg waarderen, zoals oudere hulpbehoevenden, pariënten die psychiatrisch of chronisch ziek zijn. Ook terminale patiënten zouden extramurale verpleging op prijs stellen.

'Deze terminale thuiszorg dient overigens uitsluitend te geschieden indien de pariënt daartoe de wens te kennen heeft gegeven ${ }^{7}$.'

'Terminale patiënten worden eveneens steeds vaker thuis verzorgd. Uitgangspunt hierbij is de wens van een zieke om thuis te sterven ${ }^{8}$.'

Behalve dat thuisverzorging een wens van de patiènt zou zijn, zien beleidsmakers deze wens ook als uitkomst van een weldoordacht besluit. Ze spreken over een keuzemogelijkheid tussen thuiszorg en zorg elders en menen dat hulpvragers bewust dienen te kiezen voor zorgverlening in zijn of haar thuissituatie?

... een mondige consument kan beschikken over gegevens die hem in staat stellen op kwalitatieve gronden een keuze te maken tussen de zorgverlenende instanties ${ }^{10}$ ?

'Zorgvragers kunnen kiezen of ze de benodigde zorg thuis of ergens anders willen hebben ${ }^{\mathrm{n}}$ ?

'Omdat bij patiënten die aan kanker overlijden in de regel sprake is van een terminaal ziekbed, zullen relatief veel patiënten de hierboven bedoelde keuzemogelijkheden hebben ${ }^{12}$.

Doordat beleidsmakers termen als 'kunnen' en 'bewust' koppelen aan een 'kiezende consument, zorgvrager of patiënt' maken ze duidelijk wie de plaats van zorg bepaalt. De patiënt kiest en zijn of haar ideale zorgplaats is meestal thuis. Thuis ziek zijn, is volgens het beleid, een bewuste keuze van pariënten, voortkomend uit een afweging van alternatieven, een kwestie van voors en tegens.

Hoewel patiënten alternatieven zoals ziekenhuiszorg en verpleeghuiszorg in overweging nemen, schilderen beleidsmakers die tamelijk eenzijdig af. Intramurale 
instellingen zouden 'technische', 'onpersoonlijke' en 'deprimerende' ambiances: zijn.

'Het levenseinde in het ziekenhuis is (...) teveel door medisch-technische ingrepen omgeven ${ }^{13}$.'

'De commissie meent echrer dat in het ziekenhuis de generalistische elementen van de zorg - die juist in de palliatieve en de terminale fase zo belangrijk zijn niet altijd voldoende aandacht krijgen ${ }^{14}$.'

Ziekenhuizen missen de warmte en de geborgenheid, waaraan met het overlijden voor ogen juist veel behoefte aan zou bestaan. In het beleid staat het ziekenhuis overwegend model voor het tegendeel van huiselijkheid en vertrouwdheid. Het is de plaats waar patiënten hun privacy kwijt raken en waar zij persoonlijke, vertrouwde dingen en gewoonten moeten missen waaraan ze zo hechten ${ }^{\text {ts }}$.

'In toenemende mate is men echrer her sterven in onpersoonlijke instiruten als een nadeel gaan ondervinden. Velen lijken thans daarom weer de voorkeur te geven aan her sterven temidden van hun naaste familie. Het ziekenhuis en/of verpleeghuis heeft kennelijk pas weer de voorkeur in situaties waarin her niet anders $\operatorname{kan}^{16}$.

Beleidsmakers noemen amper de eventuele voordelen van her ziekenhuis en mogelijke nadelen van zorg thuis. Over de voordelen van een verblijf in een ziekenhuis zoals bijvoorbeeld 24 -uurs hoogstaande medische en verpleegkundige zorg, zwijgen ze nagenoeg en over 'de medicalisering' van het huis reppen ze nauwelijks. De uitkomst van de keuze van de patiënt tussen sterven in het ziekenhuis of thuis maken beleidsmakers door deze asymmetrische benadering van verzorgingsplaatsen voorspelbaar. Dat patiënten bij een afweging thuis of niet-thuis tor de conclusie komen dat het vertrouwde thuis de voorkeur verdient boven het onpersoonlijke ziekenhuis, is in beleid tor feit gemaakt. Zo stellen beleidsmakers herhaaldelijk:

'De toenemende wens tot thuisverzorging $(\ldots)^{\text {it }}$.'

of

"De vraag naar thuiszorg groeit, (... ${ }^{18}$." of

'Thuiszorg zal in veel gevallen voldoen aan het criterium van het minst belastende alternatief ${ }^{19}$.'

Wie thuis ziek is, is volgens, beleidsmakers, beter af dan in een ziekenhuis. Door deze aanname zetten zij de keuze van patiënten voor de plaats van zorg vast. 
Tegelijk met de constatering dat het thuis voor patiënten het best toeven is, stellen beleidsmakers een belangrijke eis aan deze plaats. De aanwezigheid van informele verzorgers en hun bereidheid zorg te geven zou onontbeerlijk zijn.

'Aan welke voorwaarden moer in de thuissituatie worden voldaan om de beoogde substiturie te kunnen realiseren? Allereerst moet er mantelzorg zijn $^{20}$.

'Van direct belang is bijvoorbeeld (...) of de directe omgeving van de hulpvrager voldoende begrip en bereidheid heeft om het zorgproces te accepteren en te ondersteunen ${ }^{21}$.

Volgens beleidsmakers moeten er bij het geven van zorg thuis een of meer huisgenoten zijn die enige basiszorg kunnen bieden ${ }^{22}$. Zonder hen is thuiszorg onmogelijk.

Beleidsmakers beschrijven informele zorg als een onmisbaar element voor het totstandkomen van een professioneel zorgarrangement. Informele verzorgers zorgen voor continuïreit in de zorgverlening, her behoud van zelfstandigheid van patiënten en voorkomen dat de patiënt vereenzaamt.

'Mensen uit de directe omgeving van individuen die zorg nodig hebben zijn belangrijk voor de kwaliteit van de thuiszorg. Onderzoek heeft uitgewezen, dat familieleden, vrienden, vriendinnen en buren vaak de verbindende schakel zijn tussen degenen die thuis verzorgd wordt en de rest van de wereld. Zonder hen liggen sociaal isolement en vereenzaming op de loer ${ }^{23}$.'

Vooral voor ouderen, terminale patiënten en gehandicapten zou informele zorg van doorslaggevend belang zijn ${ }^{24}$. Want, zo schrijven beleidsmakers, zelfs bij mensen met ernstige beperkingen is informele zorg van groot belang bij de uitvoering van bijvoorbeeld huishoudelijke taken. Zo neemt bij de thuiswonende oudere met ernstige gebreken de informele zorg $40 \%$ van de huishoudelijk taken voor haar rekening ${ }^{25}$. Bij ziekte en gebrek dragen familie, buren en vrienden een groor deel van de verantwoordelijkheid voor de zorg van hun naasten.

Hoezeer beleidsmakers informele zorg ook waarderen, ze juichen een (wertige) plicht tot het geven van informele zorg niet toe. Zo pleiten enkele beleidsmakers ervoor dat verzorgers een keuzemogelijkheid moeten hebben russen thuiszorg en zorg elders, juist omdat dit anders voor hen de plicht meebrengt het thuiszorgproces te accepteren en hier een aanzienlijk aandeel in te leveren ${ }^{26}$. Het opleggen van informele zorg acht men ontoelaatbaar, maar dient gebaseerd te zijn op bereidheid van alle betrokkenen en hun mogelijkheden ${ }^{27}$. De norm voor thuiszorg zou de bereidheid tot het geven van informele zorg moeten zijn. Is dat niet 
het geval, dan is een indicatie voor professionele zorg gewenst ${ }^{28}$. Maar ondanks het feit dat enkele beleidsmakers een plicht tot het verlenen van informele zorg afwijzen, beschrijven ze informele zorg tegelijk als het fundament voor het thuiszorgbeleid. Want zonder dat zou thuiszorg onmogelijk zijn.

Samenvattend is te zeggen dat beleidsmakers een specifieke patiënt construeren. Deze patiënt kenmerkt zich op de eerste plaats doordat hij een duidelijke wens, wil en keuze heeft. Hij heeft met andere woorden macht de locatie van zorg te bepalen. Volgens beleidsmakers zou deze pariënt het liefst thuis willen sterven. Eén van de redenen is dat het ziekenhuis onpersoonlijk is en thuis, vanwege de aanwezigheid van verzorgers, meer vertrouwd. Wel dienen verzorgers ook een stem te krijgen in de bepaling van de zorglocatie, anders wordt het geven van informele zorg een plicht. Ter vergelijking laat ik in de volgende paragraaf verzorgers aan het woord. Ze spreken over de patiënt en meer specifiek over hun rol bij her bepalen van de verzorgingsplek.

\section{Een afhankelijke patiënt}

Heeft de patiënt gekozen voor zorg thuis? Hoe bent u er toegekomen om uw naaste thuis te laten sterven? Op deze, door mij gestelde vragen, antwoordde een verzorgster:

'Mijn man en ik vernamen op het spreekuur bij de longarts dat hij een ernstige vorm van kanker had. Hoewel we rekening gehouden hadden met deze mogelijkheid, waren we toch verbijsterd en geschrokken. We wilden heel graag weten hoe lang we samen het leven nog mochten delen. Met enige aarzeling vertelde de arts dat dit hooguit zes maanden zou zijn. Hij stelde daarop voor een palliatieve behandeling te beginnen en de bestraling en chemokuur in een speciaal daarvoor ingericht insrituut bij een ziekenhuis bij ons in de buurt te starten. In het begin van deze periode, reed mijn man zelfstandig naar dit instituut. Later werd hij door mij gebracht of ging hij met een taxi. Hij is nog eenmaal met de ambulance gegaan. Toen dat te vermoeiend werd is hij thuis op bed gaan liggen en vier weken later gestorven. Er is nooit sprake van andere zorg dan thuiszorg geweest, hij werd ziek en zieker, kwam hier op bed te liggen en is hier gestorven."

Deze ziekregeschiedenis is een voorbeeld van een situatie waarbij de patiënt vanaf de diagnosticering kanker tot aan zijn dood vanuit zijn huis behandeld en verzorgd werd. Er was, gegeven het ingezette palliatieve beleid, geen afweging tussen de ene locatie of de andere. De patiënt bleef thuis. Hij werd op de ene locatie 
behandeld, op de andere verzorgd. Aangezien de basis her huiselijke adres was en de patiënt nimmer in een ziekenhuisbed had gelegen, lag her in de lijn der verwachting dat hij thuis zou sterven.

Volgens verzorgers spreekt de plaats waar de patiënt sterft vaak voor zich. Mecstal zouden patiënten 'automatisch en vanzelfsprekend' vinuit thuis behandeld worden, zonder besef hoe lang dit gaat duren of wat dit betckent.

'I $\mathrm{k}$ weet niet precies wie besloten heeft voor thuiszorg en ook niet wie dat in gang heeft gezer, her was gewoon zo.'

Bovenstaand citaat is ryperend voor de reactie van verzorgers op de vraag wie besloot voor thuiszorg. Veelal verbaasd, soms boos maar meestal met vragende ogen keken verzorgers mij aan bij het stellen van deze vraag. Volgens verzorgers is thuisverzorging 'de gewoonste zaak van de wereld'.

De vanzelfsprekendheid waarmee bijvoorbeeld de medische staf aanneemt dat de patiënt thuis blijft komt, volgens verzorgers, niet alleen voort uit onduidelijkheid over de vraag of de zorglocatie te kiezen valt. Het is volgens hen ook moeilijk te duiden wie in dergelijke processen beslissingsbevoegdheid heeft. Zoals het eerste citaat in deze paragraaf illustreert hebben artsen een zwaarwegende stem in dat proces. Een andere verzorgster bevestigde dit en vertelde hoe de specialist merdeelde dat haar man 'uitbehandeld' was.

'De specialist zei tegen me: 'We zijn uitbehandeld.' Hij zei toen: 'Neemt u uw moeder in huis of gaat u bij haar wonen?'

Op het moment dat genezing niet meer mogelijk is, zouden artsen de patiënt of diens familie vragen goede argumenten te geven om de verzorging in het ziekenhuis plaats te laten vinden. Een medische indicatie tot opname is er niet meer, voor een sociale indicatie moeten betrokkenen geldige redenen aandragen. Volgens verzorgers zouden zelfs diegenen die het minst bij de patiënt aanwezig zijn, de artsen, de meeste macht hebben om de toekomst van de patiënt vorm te geven. Verpleegkundigen bijvoorbeeld die toch meer bij patiënten aanwezig zijn, hebben amper zeggingskracht in dergelijke 'belangwekkende' kwesties. En de zogenaamde 24-uurs mensen, waaronder de naaste verzorgers en de patiënt zelf, zij die voortdurend aanwezig zijn bij de patiënt en op die gronden een beeld hebben van, verleden, heden en toekomst van de patiënt, zijn in de medische praktijk eigenlijk voortdurend overgeleverd aan onzekerheid ${ }^{29}$. Ze zijn voor een groot deel afhankelijk van beslissingen van artsen omdat ze vaak niet weten wat er gebeuren gaat.

'We hadden geen keuze, we zijn letterlijk door de arts op straat gezet.' 
'Laat ik het zo zeggen, je voelt je heel erg alleen gelaten met die hele hap.

$\mathrm{Er}$ is geen gesprek over geweest. De specialist is uirbehandeld, de zuster zegt we kunnen niets meer voor u doen en de patiënt zegt: Ik mag naar huis. Het was dus voor mij een klus die gebeuren moest. Die klus pak je op, omdat het eigenlijk niet anders kan.'

Her is, volgens verzorgers, echter niet zo dat patiënten zich totaal ondergeschikt maken aan deze macht van 'de vanzelfsprekendheid'. Pariënten uiren zeker wel hun verlangen.

'Mijn vrouw zei: 'Ik wil bij jou blijven. Ik wil thuis sterven. (...)

'Hij wilde bij ons zijn, hij wou thuis sterven.'

'Mijn vader zei: 'Ik wil naar huis....'

Doorgaans zouden patiënten hun naasten duidelijk maken dat ze liever thuis sterven dan in een ziekenhuis. Terwijl verzorgers het idee krijgen dat de zorglocatie voor de patiënt en de verzorgers wordt bepaald, is de uitkomst van dit diffuse proces veelal conform de wens van de patiënt.

In tegenstelling tot het beleidsvertoog waar vooral de keuze en wens van de patiënt op de voorgrond staat, neemt in het zorgvertoog de wens van verzorgers een belangrijke plaats in. Ook verzorgers hebben wensen, maken afwegingen en gaan voor zover mogelijk bewust een zorgrelatie aan. Om dit nader te illustreren een brief van een verzorgster:

'Wel of niet?

Begin maart begon mijn man re sukkelen met zijn rug. Dat werd zo erg dat hij zijn werk niet meer kon doen. Hij begon met het bezoeken van de dokrers, die hem geregeld onderzochten. Daar ging hij altijd alleen op af, ik ging niet mee, omdat ik ontzettend bang ben voor alles wat met dokters te maken heeft. Als ik zelf soms naar een dokrer moest dan ging mijn man mee, gewoon omdat ik zo ontzettend bang ben voor dokters.

Het ging met mijn man steeds slechrer. Hij werd opgenomen in het ziekenhuis. Daar zouden de onderzoeken vlugger gaan en er zou eerder een uirslag bekend zijn. Dat betekende dat ik twee maal per dag naar het ziekenhuis ging. Ik was vreselijk bang. Maar het was mijn man die daar lag en die wilde ik niet in de steek laten. Hij ging immers ook met mij mee.

Op een dag moest mijn man met de ziekenauto naar een naburig ziekenhuis voor een scanneronderzoek. Omdat mijn man helemaal niet meer lopen kon, moest ik wel mee. Eigenlijk was een ziekenauto, voor mij, helemaal uit den 
boze. Ik ben er toch ingegaan. Want het is toch je man die dir moet ondergaan, die laat je toch niet in de steek?

Mijn man heeft ruim twaalf weken in het ziekenhuis gelegen, al die weken waren nou niet bepaald opgewekr. We hadden te horen gekregen dat mijn man nier meer beter zou worden. Samen hebben we heel wat afgepraat in het ziekenhuis. Ons wereldje was helemaal in elkaar gestort. Hoe moest het verder? Mijn man was moedig en sterk terwijl ik steeds banger werd. Ik had erg veel bewondering voor mijn man die maar bleef vechten voor mij. Wel kreeg hij veel heimwee naar huis. In het ziekenhuis konden ze niets meer voor hem doen. Ik was huiverig om mijn man naar huis te halen. Hoe zou het verder gaan ? Hoe zou hij dood gaan?

$\mathrm{Na}$ veel gesprekken met de huisarts is mijn man naar huis gekomen. Er waren veel maatregelen getroffen. Ondanks mijn angst kon ik mijn man toch niet in de steek laten? Toen mijn man thuis kwam is op één of andere manier mijn angst weggenomen. We zijn begonnen aan een periode die ik voor geen goud van de wereld had willen missen. Toch was het een hele moeilijke tijd. Mijn man was thuis, hij kon weer een sigaretje roken en voor zover mogelijk was vanuit zijn bed aan het huiselijke verkeer deel nemen. Ik kreeg een soort oerkracht in mij. Als de wijkverpleegster kwam om mijn man te wassen, hielp ik mee. Dar deed ik 's morgens en 's avonds. Ik hielp ook de huisarts als dat nodig was. Het ging toch om mijn man! We hebben fijn gepraat over wat ons te wachten stond. Er was een goede sfeer in huis. Mijn man krijg ik niet meer rerug maar dankzij de hulp van de wijkverpleging kan ik terug zien op vicr onvergetelijke weken samen thuis met mijn man.'

Bovenstaande brief maakt onder meer duidelijk hoezeer de verzorgster wikt en weegt, hoe ze zoekt en uiteindelijk besluit. De brief geeft inzicht in haar afwegingen. De vrouw rwijfelt of ze haar man thuis wil en kan hebben, zich realiserend dat een groot deel van de zorg op haar schouders zal gaan rusten. Alleen wanneer deze vrouw haar twijfels opzij kan zerten, vindt er thuiszorg plaats. Angst voor alles dat met ziekte te maken heeft, angst voor de dood en angst voor het onbekende, doen deze vrouw twijfelen of ze de zorg op zich zal nemen. Overleg met de huisarts, de nodige maatregelen, waaronder hulp van de wijkverpleging en het voortdurende besef dat ze deze zorg jegens haar man (moreel) verplicht is; 'het was toch mijn man die daar lag', maken dat deze vrouw informele zorg is gaan geven. Naast een beleid waarin de pariënt wenst, weegt en kiest staat in de verhalen van verzorgers ook een verzorger die zich beraadt.

Dat verzorgers afwegingen maken bij het bepalen van een zorglocatie, lijkt in tegenspraak met de eerder besproken vanzelfsprekendheid waarmee thuiszorg 
voor patiënten met kanker wordt gegeven. Dat patiënten meestal thuis verzorgd worden, betekent echter niet dat verzorgers niet zouden wikken en wegen. Ze doen dit vaak heimelijk en weinig expliciet. Het lijkt misschien ook in tegenspraak met de uitkomst van onderzoek naar motivatie van verzorgers. Hieruit blijkt (ook) hoe vanzelfsprekend het is dat zij voorkomende zorgactiviteiten zullen uitvoeren ${ }^{30}$. De morele druk is in het geval van terminale patiënten extra sterk ondat het moeilijk is de 'laatste dienst' aan de patiënt te ontzeggen. Er wordt een sterk moreel appèl op verzorgers gedaan, waardoor verzorgers de zwaarte van de verzorgingslast soms bagarelliseren of ontkennen. Tegen de achtergrond van de dood past het volgens verzorgers niet te klagen over dingen die daarmee vergeleken furiliteiren zijn ${ }^{31}$.

'Je kunt het nooit meer overdoen. Als je het op dat moment nier doet. Je kunt het nooit meer doen. Daarom zorgden we voor moeder.'

'Je weet dit is het einde. Dit is het laatste, dus je moet het doen.'

In een situatie waarbij de dood in de ogen wordt gekeken, lijken dagelijkse beslommeringen van verzorgers relatief en onbelangrijk. Verzorgers balanceren voor en gedurende het zorgproces tussen standvastigheid en twijfel, tussen vreugde en pijn, maar voelen en weten zo zeggen ze, dat de dood nabij is en zijn bereid, hoe moeilijk dat ook is, daar een deel van hun eigen leven voor opzij te zetten.

'Onze beste vriend stelde ons de vraag "mag ik bij jullie dood gaan?"

We twijfelden geen moment, we hadden geen keus. Ik dacht dat ik deze vraag voor iedereen met ja zou beantwoorden. Ik weet nu echter wel beter.

Je kunt pas iemand thuis verplegen en thuis laten sterven als je voor die persoon heel erg veel over hebt. Je moet verschrikkelijk om hem geven en je realiseren dat je alleen met veel geduld, liefde en hulp zo'n enorm karwei kunt klaren. Mijn man en ik stapten in een avontuur waarvan we de uitkomst dachten te weten. Natuurlijk wisten we dat de dood ergens wachtte? Maar war? We realiseerden ons absoluut nier dar we hulp van buitenaf nodig zou moeten hebben. Nu weten we wel beter. Het omgaan met de dood is heel erg zwaar. Eén ding moet duidelijk zijn we hebben geen spijt, absoluut geen spijt. Voor die vriend doen we het zo weer.

Toen onze vriend bij ons in huis kwam, wilde hij rust vinden om zijn leven op een rijtje te zetten. Hij wilde met zijn moeder praten en over zijn overleden vader nadenken. Hij moest nog zoveel.

We hebben geprobeerd hem die rust re geven, hem lichamelijk zo goed mogelijk te verzorgen, we hebben geprobeerd hem te laten nadenken over zijn dood. 
Bijvoorbeeld over de prakrische zaken daaromheen. Wil je begraven worden of gecremeerd?

We hebben nagedacht over onze vriendschap, we hebben gehuild om het gemis dat we voelden aan komen, we zijn boos geweest. Dat deden we allemaal samen, samen. Juist omdat hij bij ons was hebben we dat allemaal met elkaar kunnen doen.

Ik heb hem dood zien gaan. ik had mijn armen om hem heen en zei alleen maar: "Goede reis, lieverd".

Hij was dood en het was goed zo, het was klaar, af. Ik mis hem nog iedere dag. Ik mis hem heel erg.'

De verzorgster uit bovenstaand citaat start de zorgrelatie vanuit vriendschap en liefde en vertelt daarna hoe zwaar dit traject is geweest. Een andere verzorgster liet me weten dat de relarie met haar man voordat hij ziek werd al ernstig was verstoord. Hierdoor was het aangaan van een zorgrelatie voor haar veel minder vanzelfsprekend. Ze moest eerst haar eigen pijn, teleurstelling opzij zetten en rancuneuze gevoelens trotseren. Desondanks heeft ook zij haar man verzorgd.

'Mijn mans grote angst werd bevestigd toen de artsen asbestkanker constateerden. Enkele collega's van hem waren er al aan gestorven.

Hoewel het nog moeilijk voor me is, durf ik nu wel te zeggen dat mijn huwelijk al lang voor die rijd stuk was.

Ik had vaak blauwe plekken en als iemand daar naar vroeg dan zei ik dat mijn man dat had gedaan, maar niemand geloofde dat.

Hij had ook een vriendin en als ik werkte was hij bij haar.

Mijn man lag in het ziekenhuis toen hij me vroeg of hij thuis mocht sterven. Hij zei erbij: 'Ik weet dat ik nu iets van je vraag wat eigenlijk nier kan'.

Toen heb ik heel gemeen gezegd: 'Moet je niet naar je liefje toe?'

Ik moest nadenken over de vraag of hij bij mij sterven mocht en ben een poosje naar buiten gegaan. Aanvankelijk wilde ik niet dat hij thuis kwam, ik kon het niet opbrengen. Na wat overpeinzingen, dacht ik, her begin van ons huwelijk was goed. Bovendien hebben we samen een kind.

Ik ben toen naar hem toegegaan en heb hem gezegd dat hij naar huis kon komen.'

Naast het eenmalige, onherroepelijke karakter, speelt in het geval van patiënten met kanker ook op ander vlak de aard van de ziekte een rol in de stilzwijgendheid waarmee de verzorger haar rol opneemt. Ziekteverschijnselen hebben zich vaak langzaam en sluipenderwijs aangediend. Voordat de arts de diagnose stelt is het zorgtraject vaak al ingezet. Een verzorgster, wiens man aan een hersentu- 
mor overleed, schreef dat ze zich al geruime tijd afvroeg wat haar man toch mankeerde.

'Hij was zo moeilijk, grauwen en snauwen. Ik dacht dat hij overspannen was en zei: Ga eens naar de dokter, maar volgens hem mankeerde hij niets. Toen het niet meer ging en hij echt vreemde dingen ging doen, was ik geestelijk en lichamelijk al een eind afgeknapt. Eindelijk kwam hij via de huisarts bij de neuroloog. Hij moest meteen in het ziekenhuis blijven, maar na 13 dagen kon hij weer naar huis. Ongeneeslijk. ziek. Hij is nog acht maanden thuis geweest en je gaat maar door.'

Verzorgers groeien over her algemeen met het ziekteproces mee waardoor zij zichzelf als de meest aangewezen persoon zien om de zorg op zich te nemen. Onderzoekers trekken de conclusie dat door de morele druk voor zorgende partners en een zorgtraject dat langzaam start, zorg geven evident is. Hoewel deze onderzoeken duidelijk maken dat de uirkomst van een afweging over het wel of niet zorgen vaak dezelfde is, en verzorgers zich genoodzaakt zien te zorgen, betekent het echter niet dat verzorgers geen afwegingen maken. Ze doen dit over de vraag of ze zullen zorgen en dit is uiteraard verbonden met de plaats waar de patiënt zorg ontvangt.

Samenvattend is te zeggen dat verzorgers het aangaan van een zorgrelatie als onontkoombaar beschouwen. Zo zou de patiënt de zorglocatie niet kiezen maar door verschillende krachten naar huis worden geduwd. Artsen kunnen niets meer voor de pariënt doen, pariënten willen graag naar huis en verzorgers overwegen weliswaar of ze de zorgrol op zich zullen nemen, maar doen dit in stilte. Hun antwoord staat, gegeven de situatie, min of meer vast. Dit betekent dat verzorgers de patiënt en zichzelf voortdurend plaatsen in een netwerk van afhankelijkheidsrelaties. Tegenover 'de kiezende cq. autonome patiënt' die beleidsmakers veronderstellen, zetten verzorgers een afhankelijk individu.

\section{Helende huizen}

Thuis, definiëren beleidsmakers als een plek waar een groot aantal medische diensten en zorgactiviteiten naar toe getransporteerd kunnen worden. Verschillende nota's bouwen voort op wat in de jaren rachtig in gang is gezer. Mensen mogelijk maken zo lang als het kan thuis, in de eigen omgeving, te laten verblijven, of daar zo snel mogelijk weer naar terug te laten gaan ${ }^{32}$. Dat beleidsmakers pleiten voor relocatie van zorg vanuit het ziekenhuis naar thuis betekent dat ze aan ( $t$ )huis ten opzichte van het ziekenhuis een specifieke betekenis geven. 
Beleidsmakers beschrijven 'thuis' op de eerste plaats als een huis; een plek met vier muren, die zich onderscheidt van andere verblijfsruimten. In tegenstelling tot openbare zorginstellingen biedt her huis mogelijkheid tot privacy. Het in beleid beschreven huis zou zich kenmerken doordar her 'autonomie' en 'zelfstandigheid' van mensen waarborgt.

'(...) het Regeringsbeleid is er -onder meer-op gericht om een verschuiving teweeg te brengen van intramurale naar extramurale zorgverlening, en van professionele hulpverlening naar zelfzorg en mantelzorg. Bovendien (...) dient zelfstandigheid van het individu te worden bevorderd. Voor de oudere mens dient het begrip zelfstandigheid nog te worden aangevuld met gelijkwaardigheid en onafhankelijkheid. Het mogelijk maken van deze drie beleidsuitgangspunten vergt een zorgverlening die daarop is toegesneden. Al langer wordt de behoefte gevoeld om in sommige situaties verpleging thuis, zowel verzekeringstechnisch als zorgverleningstechnisch mogelijk te maken ${ }^{33}$.'

'In deze woonsituatie bestaan de beste voorwaarden voor het handhaven van de autonomie van de hulpvrager ${ }^{34}$.'

'De commissie acht her daarom van essentieel belang dat juist deze autonomie en zeggenschap in de thuiszorg inderdaad zoveel mogelijk behouden blijven ${ }^{35}$.'

Het huis zou oudere mensen en andere hulpvragers handelingsvrijheid bieden, ze zijn juist daar eigen baas. Hun zelfbeschikking zou meer gegarandeerd zijn dan in een ziekenhuis. In dit huis kunnen patiënten doen wat zij willen.

Beleidsmakers definiëren thuis niet alleen als een plek die autonomie waarborgt, maar eveneens als een sociaal, vertrouwd netwerk gevormd door aanwezigheid van naasten. Patiënten zouden als het even mogelijk is, in de eigen vertrouwde omgcving behandeld en verzorgd willen worden.

"Voor een belangrijk deel is de huidige belangstelling voor thuiszorg voortgekomen uit een maatschappelijk gevoelde behoefte aan 'humarisering' van de zorgverlening en her zoveel mogelijk in stand houden van de relatie van de hulpvrager met diens directe omgeving ${ }^{36}$.

'Mensen willen zo lang mogelijk hun eigen autonomie behouden, in hun eigen vertrouwde omgeving, samen met mensen die hen diẹbaar zijn ${ }^{37}$.'

De aanwezigheid van dierbaren ofwel de relatie van de hulpvrager met diens directe omgeving garandeert vertrouwdheid. Enerzijds verbinden beleidsmakers 'her huis' dus met autonomie dat refereert aan een notie van privacy, anderzijds 
associëren ze 'huis' met 'vertrouwdheid' en 'humanisering'. Hiervoor staat de familie ofwel 'het sociaal netwerk' symbool.

Aan de rweede betekenis, het huis als het symbool voor het 'sociale netwerk', hechten beleidsmakers buitengewoon belang. Dit netwerk zorgt er, zoals eerder gezegd, voor dat patiënten niet aanhoudend afhankelijk zijn van professionele zorg. Hierdoor behouden ze hun onafhankelijkheid ${ }^{38}$. Bovendien vloeit de zorg die dit netwerk geeft rechrstreeks voort uit de sociale relatie. $\mathrm{Z}_{\mathrm{ij}}$ is in tegenstelling tot zorg van professionals spontaan ${ }^{39}$. Ook zou het sociale netwerk voorkomen dat de hulpvrager geïsoleerd raakt van zijn sociale omgeving. Het voorkom dat een patiënt zich moederziel alleen weet, waardoor de kwaliteit van leven aan waarde wint. Zonder dit netwerk liggen sociaal isolement en vereenzaming op de loer ${ }^{40}$. Opname in een intramurale instelling isoleert de hulpvrager wel, is de beleidsveronderstelling. Alle aandacht zou in die instellingen gericht zijn op ziekte of handicap. Het intact houden van de relatie met het sociaal netwerk vormt één van de sterke punten van zorg in de thuissituatie, aldus beleidsmakers ${ }^{41}$. Zij definiëren familieleden en partners als de verbindende schakel tussen degene die thuis zorg ontvangt en de rest van de wereld ${ }^{42}$. Het sociaal nerwerk zou een positief effect hebben op het welbevinden van patiënten en een gunstige rol spelen bij de verwerking van ziekte.

Opvallend is dat beleidsmakers alleen positieve kanten van de relatie tussen pariënten en hun sociaal netwerk noemen. Over onderlinge spanningen spreken ze bijvoorbeeld niet. Hierdoor is deze relatie per definitie ondersteunend. Dit kan mogelijk verklaard worden doordat beleidsmakers de betekenis van een sociaal netwerk enkel vanuit het perspectief van patiënten beschrijven. Wat het voor het 'sociale netwerk' (zelf) betekent om zorg aan een zieke te geven, krijgt bij de beschrijving van de noodzaak tot extramuralisatie minder aandacht. En als er bij beleidsmakers interesse is voor wensen in 'her sociaal nerwerk' lijkt ook dat één richting uit te gaan, namelijk zo dat verzorgers graag zorg geven.

'Langdurige verpleging en verzorging vindt waar mogelijk thuis plaars. In het overgrote deel van de behoefte aan zorg voorziet de directe omgeving van de betrokkene, zonder dat daar een betaling tegenover staat ${ }^{43}$,

'In de prakrijk zullen overigens vaak de cliënt als de mantelzorger bereid zijn on geen professionele zorg te vragen, omdat het verlenen van mantelzorg - indien gegeven en ontvangen op vrijwillige basis - voor beide parrijen een duidelijke meerwaarde heeft ${ }^{44}$.' 
Afgezien van het feit dat het contact met gezin of familie voor patiënten van onschatbare waarde kan zijn, beschrijven beleidsmakers 'het sociale nerwerk' op zo'n manier dat dit (bijna) volledig ten dienste van patiënten staat.

De dienstbaarheid van dit netwerk komt ook tot uitdrukking in de talige presentatie ervan. Vanaf de start van het informele zorgbeleid vormen patiënt en informele zorg een twee-eenheid. Beleidsmakers presenteren bijvoorbeeld een zorgmodel waarin zelf- en informele zorg tezamen het nulde echelon vormen. In dit model zijn zelfzorg (de patiënt) en informele zorg (de sociale omgeving) automatisch mer elkaar verbonden. Beleidsmakers beschrijven patiënten steeds in samenhang met hun sociale omgeving.

Ook in navolgende beleidsteksten is her gebruik van deze constructie gangbaar. Beleidsmakers noemen pariënten in één adem mer hun verzorger. Ze spreken over 'zelfzorg en mantelzorg', 'patiënt en diens omgeving' of 'patiënt en familie'.

'Met de zelfzorg en mantelzorg is het minder slecht gesteld dan vaak gedacht wordt ${ }^{45}$ ?'

\section{"(...) de patiënt en diens omgeving zouden relkens die zorg krijgen die bij de specifieke situarie past ${ }^{46}$.'}

'Het is voor patiënt en familie van belang dat zij alle betrokken hulpverleners op een gemakkelijke manier, liefst op een centraal punt, kunnen bereiken ${ }^{47}$.'

Hoewel beleidsmakers patiënten en hun 'mantelzorg', 'omgeving' of 'familie' wel apart noemen, lichten zij hun specificke situaties, kwaliteiten of problemen er niet uit, maar scheren deze over één kam. Ze worden vereenzelvigd. Op die manier staat de verzorger eveneens in dienst van de patiënt.

In latere nota's zijn beleidsmakers deze gezamenlijkheid van patiënt en familie 'het cliëntsysteern' gaan noemen. Met de introductie van dit begrip is de vereenzelviging compleet en is het bijna raadselachtig wie de cliënt is.

'De indicarieadviseur zal zelf een goede inscharting moeten maken van de draagkracht-draaglast verhouding van het cliëntsysteem ${ }^{48}$.

Is de cliënt de zieke die graag door zijn partner wordt verzorgd? Is dat de verzorger die graag haar baan buitenshuis houdt? Ook al lijkt het alsof beleidsmakers verzorgers in het beleid een belangrijke plek geven, door de versmelting met de patiënt maken ze echter hun behoefte aan autonomie of zelfstandigheid onzichtbaar. 
Dat beleidsmakers de verlangens van verzorgers verloochenen, komt nog sterker tot uirdrukking wanneer ze hen anonimiseren of 'ontmenselijken.' Ze duiden verzorgers nog al eens ruimtelijk, ze zijn omgevingen en naamloos.

'Her actief betrekken van de thuisomgeving bij de zorg aan de hulpvrager kan namelijk voorkomen dat de laatste in de beleving van zijn/haar ziek zijn of handicap gë̈soleerd raakt ${ }^{49}$.'

'Bij de mogelijkheid tot thuiszorg spelen kenmerken van de patiënt, de ziekte en de omgeving en rol ${ }^{\text {so }}$.

'De pariënt en diens omgeving zou telkens die zorg krijgen die bij de specifieke situatie past ${ }^{51}$.

'Behalve de hierboven genoemdc hulpverlencers met beroepsspecificke inbreng wordt in her kader van de terminale thuiszorg hulp geboden door de omgeving $(\ldots)^{52}$.'

Het gebruik van begrippen als 'thuisomgeving' of 'omgeving', maakt dat noden en wensen van 'die omgeving' niet bestaan. Dit zou tot gevolg kunnen hebben dat de zorgarbeid van verzorgers in tegenstelling tot de zorg die professionals in andere echelons van het zorgsysteem bieden, gemakkelijk beschouwd wordt als liefdewerk ". Want hoezeer beleidsmakers ook trachten 'de omgeving' als waardevolle component van het huis te beschrijven, 'omgevingen' praten niet, hebben behoeften noch verlangens.

Misschien is deze vereenzelviging van patiënt en verzorger in beleid weinig opzienbarend. Sterker nog: lijkt her benoemen van beide beleidsactoren in zeker opzicht een emancipatoire daad omdat tot voor kort in beleid de zorgaanbieder nog centraal stond. In plaats hiervan is nu het denken vanuit de zorgvrager geïntroduceerd. Het noemen van 'de zelfzorg en informele zorg', 'patiënten en hun omgeving' of 'het cliëntsysteem' in het zorgbeleid is die gedachtengang volgend een erkenning van hen. Anderzijds is door de vereenzelviging van 'patiënt en omgeving' niet duidelijk wic precies de zorgvrager is. Als beleidsmakers schrijven dat 'de patiënt en diens familie telkens die zorg krijgen die bij hun past', gaan ze ervan uit dat wat de patiënt wil ook de wens van de familie is. Met andere woorden: het gebruik van deze twee-eenheid in beleid, verdoezelt ook wanneer de nadruk op de zorgvrager (welke?) ligt, de mogelijkheid van een patiënt en een verzorger met verschillende behoefren en verlangens.

Toch merken sommige beleidsmakers de versmelting van de verzorger mer de patiënt wel op. Aan de ene kant stellen ze dat de patiënt en degenen die hem 
mantelzorg verlenen als een onverbrekelijke eenheid moeten worden beschouwd. Aan de andere kant wordt erkend dat daarbinnen wel verschil yan opvatuing kan bestaan $^{34}$. Een identieke benadering van deze twee verschillende zorgvragers is op zo $n$ moment niet wenselijk ${ }^{55}$. Dit is een uitzonderlijke, maar in dit kader interessante notie. Maar ook hierbij is de toonzerting specifiek. Dat een verzorger eigen behoeften heeft, is volgens beleidsmakers geen vanzelfsprekendheid, uitdaging of kans, maar een complicatie. Behoeften van verzorgers vormen, in het kader van extramuralisatie van zorg, een probleem.

'In de thuiszorg is er nog een complicatie, doordat deze zorg niet alleen gericht is op een bepaalde persoon met een functiestoornis, maar ook bedoeld is als steun en gedeeltelijke vervanging van informele zorg in de omgeving. Hierdoor gaan ook de behoeften van anderen dan de zieke of gehandicapte een rol spelen $^{56}$ :

Een tweede blijk van aandacht in het beleid van de laatste jaren voor behoeften van verzorgers is af te leiden uit aandacht voor de precaire positie van 'de naaste omgeving'. Hoewel 'de naaste omgeving' zich vele inspanningen getroost om de patiènt thuis te verzorgen, blijken toch extra voorzieningen nodig om hen zo goed mogelijk te steunen ${ }^{57}$. Systematisch wijzen beleidsmakers op de problematische situatie waarin 'omgevingen' zich bevinden. Hun draaglast is te groot, ze hebben teveel taken en moeten behoed worden voor burn-out.

Hoewel deze aandacht voor de problemen van verzorgers op het eerste gezicht een meer reële verhouding tussen verzorger en patiënt lijkt te weerspiegelen, bevestigt die aandacht indirect de vereenzelviging van patiënt en verzorger. Want doordat beleidsmakers het onvermogen en niet het vermogen van de verzorgers benadrukken, (veronder)stellen ze dat verzorgers zichzelf aanpassen of willen veranderen om thuiszorg mogelijk te maken. De patiènt zijn wens voor thuiszorg zou, volgens beleidsmakers, automatisch de wens van de verzorger zijn. Op die manier construeren beleidsmakers, weliswaar indirect, wederom een vereenzelviging tussen verzorger en patiënt.

Met de aanname dat verzorger en patiënt gelijke wensen hebben, maken beleidsmakers verzorgers tot bondgenoor van patiënten. Het beleid incorporeert verzorgers in het zorgsysteem en definieert ze zo dat ze als vanzelf al het mogelijke doen de wens van de patiënt in te willigen. In het beleid staat de wens van de patiënt voorop. Dat is de wens thuis te zijn. Verzorgers zijn als het ware een meubelstuk in dat huis, een onderdeel, zonder stem, zonder rechten, maar iets of iemand die zonder afweging geneigd is comfort te bieden. Juist deze omschrijving van het sociaal netwerk' maakt het geven van informele zorg vanzelfsprekend ${ }^{58}$. Ondanks de verdergande medicalisering van significante gebeurtenissen in een leven, bete- 
kent thuis zijn in essentie dat de zieke niet 'helemaal' of 'alleen maar' ziek is. In beleid heeft thuis zijn een herstellend effect op de zieke en daartoe moet 'de omgeving' of 'informele verzorger' voor zorg, liefde en eenheid met de patiënt staan.

Samengevat beschrijven beleidsmakers her huis vanuit het perspectief van patiënten. Het huis zou staan voor een plek die hun autonomie waarborgt en voor 'een sociale omgeving' die ondersteunend en helend werkt. Thuis is aldus een symbool dat onafhankelijkheid, comfort en bescherming vertegenwoordigt. In. de volgende paragraaf zal ik deze noties van het huis vergelijken met die van verzorgers.

\section{De huis-gevangene}

Volgens belleidsmakers biedt een ziekbed thuis, in vergelijking tot een opname in een ziekenhuis, autonomie aan patiënten. Dit veronderstellen verzorgers eveneens. Patiënten hebben volgens hen thuis meer zeggenschap over de invulling van hun leven, over de zorg die ze wensen en het ritme waarin dat gebeurt. Ze zijn thuis nauwelijks onderworpen aan een regime van slaap-, bezoek-, en eettijden ${ }^{59}$. Zo zou een zieke tot z'n verzorgster hebben gezegd:

'Als ik nu in her ziekenhuis was of ergens anders dan gingen om 22.00 uur de deuren dicht, maar ik kan hier 's nachts aan jou een bakje rijstepap vragen en dar krijg ik dan ook.'

In bovenstaand citaat is te lezen hoezeer de pariënt het volgens zijn partnerverzorgster waardeerde op vreemde tijden eigenzinnige eetwensen ingewilligd te zien. Ook volgens verzorgers komt deze, niet aan ritme of tijd gebonden zorg de kwaliteit van het leven van de zieke ten goede.

Hoewel dit voorbeeld het autonome handelen van patiënten thuis bevestigt, laat het ook zien hoe het autonomie van verzorgers inperkt. Want wie zal de rijstepap maken? Wie zal deze de zieke aanreiken? En wiens nachtrust is verstoord? Verzorgers bevestigen dus niet alleen het idee dat thuis autonomie aan patiënten biedt en dat dit hun kwaliteit van leven verhoogt, maar beweren tevens dat thuiszorg hun autonomie beperkt.

Indien een patiënt thuis zijn ziekbed heeft, stemt de verzorger haar dagindeling gedurende korte of lange tijd af op die van de patiënt. Zo bepaalt het ritme van de zieke het ritme van de verzorger, dag in dag uit. Een verzorgster vertelde bijvoorbeeld hoe zij gedurende maanden haar dagindeling volledig richtte op de 
noden van haar man en instelde op de wensen en beschikbare tijd van de wijkverpleegkundigen.

'...'s Morgens om acht uur stond ik op. Ik sliep in een andere kamer want hij kon me niet meer naast zich verdragen. Ik ging dan kijken hoe het was. Je kijkt en doet wat je kunt doen. Kussen opschudden, drinken halen, beetje zalf. Dan waste ik mezelf en wachtte tot 'de wijk kwam', dat was om ongeveer 10.00u. Eerst een beetje praten en dan hielp ik mee. Dat vinden ze pretrig. Wassen, verzorgen, schone spullen. Dan even aan tafel zitten en wat drinken en eten. Het was inmiddels rr.oou. Wij waren dan blij als hij even uit bed kwam. Dat ging onder protest want hij wilde dat nier. Hij was echt bekaf na het wassen. Na een half uurtje ging hij weer terug in bed. Voor de rest van de dag was ik dus alleen met en voor hem.'

Toen haar man gestorven was stond deze vrouw nog gedurende enkele weken om $8.00 \mathrm{u} \mathrm{op}$, liep naar de kamer naast de hare, waste zich in ijltempo om te wachten op de hulp die natuurlijk niet meer kwam. Haar dagindeling kreeg een ritueel karakter toen het niet langer bijdroeg aan de zorgtaak. De strikte tijdsindeling, stond volgens haar symbool voor een complete overlevering aan haar man ${ }^{60}$. Een andere verzorgster vertelde hoe de zorg voor een vriend niet alleen haar dagritme maar ook het nachtleven bepaalde.

'Drie weken voor zijn overlijden moest Gerard me zeker drie keer per nacht wakker maken om hem te helpen. Hij vond dat verschrikkelijk om te doen, maar kon niet anders. Zijn wond moest verschoond worden en hij kon dat echt niet zelf. Bovendien waren de nachten zo lang en eenzaam. 's Nachts was het rustig in huis en hij (en ik ook) vond her heerlijk om stil samen hand en hand te zitren. Geen kinderen die rondrennen, hoe stapelgek hij ook op ze was. lemand die weet dat hij niet lang meer te leven heeft, heeft toch alle recht van de wereld op dat kleine beetje aandacht. I wilde hem die aandacht zo vreselijk graag geven, maar viel soms bij hem in slaap. Zo moe, zo vreselijk moe.'

Het levensritme van beide verzorgsters is synchroon gaan lopen met dat van 'hun patiënten'. Het is dan ook niet verwonderlijk dat de verzorgers aangeveñ dat ze afgemat zijn, laat staan dat er nog tijd en energie is voor hobby's als sport, lezen of uitgaan ${ }^{6}$.

Dat verzorgers weinig hobby's uitoefenen, komt ook omdat ze beperkt zijn in hun leefruimte. Vooral activiteiten die een zekere mobiliteit vragen moeten het ontgelden ${ }^{63}$. Op bezoek gaan, uitstapjes maken, winkelen en op vakantie gaan zijn activiteiten die verzorgers niet zo vaak doen. De wereld van de informele verzorgers is klein. $\mathrm{Zij}$ zijn vaak thuis bij de zieke. Een intense angst bij verzorgers 
is het idee de zieke alleen te moeten laten ${ }^{63}$. Schrijnend is het voorbeeld van een man die zich letterlijk vastbond aan zijn vrouw, bang als hij was 's nachts te slapen als zij hem nodig had.

'Mijn vrouw was 's nachts heel onrustig van de pijn. Ze stapre door die medicijnen dan versuft uit bed. Ik vond dat eng en had een rouwtje om haar pols en de mijne gebonden. Als ze dan overeind kwam werd ik ook wakker.'

Verzorgers zijn bezorgd dat de zieke hulp nodig heeft terwijl ze slapen of er niet zijn, hun medicijnen nier kunnen innemen of dood zouden gaan zonder iemand in hun omgeving te hebben ${ }^{64}$. De aanhoudende angst en bezorgdheid om her welbevinden van de zieke, bewerkstelligen dat verzorgers niet graag uit de buurt van de zieke gaan.

Hoewel verzorgers behoefte voelen 'er eens uit te gaan', vinden ze het lastig de zorg aan anderen over te laten. Dit geeft spanning omdat verzorgers enerzijds ruimte voor zichzelf wensen, anderzijds voelen dat de zieke een zwaar beroep op hen doet.

'Ik. moest af en toe morfine halen, dat kreeg mijn zoon niet mee. Ook moest ik af en toe even geld halen, of wilde ik gewoon even weg. Dan vroeg ik bijvoorbeeld aan zijn broer of hij eventjes wilde oppassen. Dat wilde hij wel. Maar niet van harte, hij was toch wat bang. Dus ik ging roets, roets en was snel weer thuis.

Vooral vrouwelijke veizorgers zouden het moeilijk vinden de zieke alleen thuis te laten ${ }^{65}$. Juist zij gaan er traditiegetrouw vanuit dat ze hun partner gezelschap moeten houden en er voor hun partner moeten zijn. Dit zou samenhangen met maatschappelijke normen over een goede (vrouwelijke) partner. Kiest de verzorger voor zichzelf, dan is er het gevoel de zieke tekort te doen, kiest ze voor de zieke dan doet ze in zekere zin zichzelf tekort.

Is het voor verzorgers al moeilijk de zieke 'los te laten', het wordt nog moeilijker als pariënten hun nabijheid claimen. 'Ik mocht haast geen boodschappen doen, zegr een zorgende dochter. 'Als ik tien minuten weg was dan zei hij: 'waar blijft ze nou?' Een verzorgster die mer haar man bij haar zwager en zijn enigszins labiele echtgenote introk vertelde:

'Ik ben bijvoorbeeld helemaal geen stadsmens, maar het idee dat er een paat kilometer verderop een mooie stad lag, dat je daar niet kwam. We zijn in het begin een keer een avond weg geweest. We kwamen terug en toen zeiden ze: 'Jullie zijn ook lang weggeweest'. We hadden nog geen uur op een terrasje gezeten. Gewoon het idee dat je nier weg kon. Dat drukte op me.' 
Op subtiele en minder fijnzinnige wijzen maken zieken duidelijk dat de verzorger in de buurt moet blijven. De combinatie van een verzorger die het moeilijk vindt een zieke alleen te laten en een zieke die het prettig vindt een verzorger in de buurt te hebben, maken dat verzorgers in een kleine wereld leven.

Niet alleen de claim van een zieke, ook het thuis opgesloten te zitten ofwel een leven in een klein, door ziekte gekarakteriseerd domein, dragen bij aan een eenzaam bestaan ${ }^{66}$. Zo zou het bijvoorbeeld voor verzorgers moeilijk zijn andere sociale contacten aan te houden dan die met de zieke en de professionals. Het eerder geciteerde echtpaar verliet huis en haard om drie maanden voor de broer van de man, in een stad $300 \mathrm{~km}$ van hun woonplaats, te zorgen. Daardoor moesten ze hun huis, vrienden en het sociale leven achterlaten. In een ander geval blijven bekenden, vrienden of kerkgenoten weg.

'Sinds de ziekte van mijn man kom ik niet meer in de kerk. Wat heb ik aan een kerkgemeenschap die niet naar me omkijkr in moeilijke tijden? Stel nu dat ik daar 's zondags heen zou gaan en ik zie ze daar zitten met opgeheven hoofd, zingen en belijden wat ze 's maandags niet doen. Dan kan ik alleen maar denken: 'Stelletje huichelaars.' Nooit heb ik kunnen vermoeden dat het zo ingrijpend zou zijn. Ik voel me vreselijk in de steek gelaten en dat komt hard aan.'

Paradoxaal genoeg wordt het gevoel thuis 'gevangen te zitten' mede veroorzaakt doordat het huis in toenemende mate publiek terrein wordt. Zoals in het ziekenhuis verschillende mensen de ziekenkamer in en uit lopen en benodigde middelen rond het bed van de zieke verzamelen, zo wordt het huis of een deel hiervan, de slaap-, of de huiskamer, meer en meer door buitenstaanders ingenomen.

'Soms leek her hier net een duiventil. De wijkverpleegster kwam iedere dag, de gezinshulp en dan weer iemand om de tillift te brengen of te monteren. Dat ding was om de haverklap kapot.'

Hoewel verzorgers dankbaar zijn voor de steun van professionals, beknelt die ook. Professionele verzorgers, gezinsverzorgenden en pastores komen geregeld binnen. Artsen komen visites afleggen, verpleegkundigen komen de zieke verzorgen, bezoek meldt zich gedurende de dag. De uitleenafdeling van de thuiszorg brengt een hoog-laag bed, een opklapbaar tafeltje vervangt het nachrkastje en dossiers en telefoonnummers van de verschillende hulpverleners liggen bijeen op de lectuurmand. De po staat 's nachts naast het bed, de telefoon en medicatie staan naast de zieke. Mede door deze invasie van goedwillende professionals en hun instrumenten voelen verzorgers zich in toenemende mate gevangen. 
Behalve een beperking in mogelijkheden tot het indelen van hun tijd en een begrensde bewegingsruimte leggen professionele verzorgers het zorggedrag van verzorgers aan banden, waardoor het gevoel 'gevangen te zijn' wordt versterkt. Met hun behandeling, verpleging en verzorging, ondersteuning en begeleiding van de patiënt brengen ze automatisch beroepscodes en regels het huis mee in. Bij patiënten met kanker in een terminaal stadium is de diversiteit aan hulpverleners bovendien erg groot. Alleen voor zorgacciviteiten komen soms al vier verschillende disciplines ${ }^{67}$. Zo vertelde een vrouw wier man ernstig ziek was en die bovendien pas was bevallen, dat het aantal hulpverleners gedurende haar kraamtijd 'de spuigaten uitliep'. Iedere ochtend waren een kraamhulp, gezinshulp, een ziekenverzorgende en een wijkverpleegkundige aanwezig. Door de diversiteit aan zorgverleners nam ook het aantal en soort gedragsregels toe. Zij vertelde dat door strikte naleving van dit soort regels, die bijvoorbeeld voorschreven welke zorgverlener welke handeling mocht verrichten, haar handelen werd beperkt.

'War heb ik aan een wijkverpleegkundige, die alleen kan komen wassen, maar niet een paar uur kan blijven zodat ik iets voor mijzelf kan doen. Dan doe ik het wassen liever zelf. Een gezinshulp, die nier mag helpen tillen, een kraamhulp die geen medicijnen mag klaar zerten. Als zij een niet zo duidelijk omschreven taakgebied hebben en een misschien wat ruimere opleiding, dan hadden wij nier zo'n invasie van hulpverleners in huis gehad. Want je privacy is ver te zoeken (...). Heerlijk die rustige uurtjes 's avonds.'

Deze verzorgster was boos omdat door alle regels het zicht op de zorg als geheel verloren ging en haar wensen ondergeschikt bleken aan die van de zorgaanbieders. Ze voelde zich beperkt en was onmachrig hier verandering in te brengen.

Dergelijke fragmentatie van activiteiten heeft soms functionele discontinuïteit in de zorg tot gevolg ${ }^{68}$. Doordat verschillende professionals problemen anders verwoorden of benaderen kunnen communicatiestoornissen tussen professionals en verzorgers ontstaan. Dit zou dan een oorzak zijn dat verzorgers zich in hun eigenwaarde en autonomie aangetast voelen.

'De nachtzusters waren ook niet altijd dezelfde, ik heb vier verschillende gehad.

Het waren scharten, maar de één wilde dit, de ander dar. En ik..? Ik voelde me op bezoek in eigen huis.'

In dit licht is her niet verwonderlijk dat de eerder geciteerde verzorgster de rustige uren 's avonds roemt. Dan zijn de hulpverleners verdwenen zijn en vertelt niemand haar hoe te handelen.

Voorbeelden van regels van professionals die het handelen van verzorgers thuis bepalen en beperken zijn er genoeg. Zo beperkt bijvoorbeeld het maximale 
bezoekrecht van wijkverpleegkundigen her handelen van verzorgenden. In sommige steden mag een wijkverpleegkundige niet meer dan drie maal per dag de patiënt verzorgen. Deze bezoeken vinden op een min of meer vaststaand tijdstip plaats en zijn daarom beperkend voor de verzorger.

'Het was vroeg in de ochtend, 6.00 uur. Mijn man zei: 'Ik moet drukken'. Ja, zo'n zuster kome dan om 9.00 uur. Zij zei wel: 'Ik ben er om uw man te wassen'. Maar ja, als iemand in de stront ligt kun je hem toch niet laten liggen, tot 9.00 uur? De wijkverpleegkundige maakte zich wel bezorgd over mij, eigenlijk vond ze het niet goed dat ik het deed. Maar wat nou, niet goed?'

Een andere verzorgster vertelt hoe verbolgen ze was, toen de wijkverpleegkundige haar bleef voorhouden dat de geboden professionele hulp, vanwege een maximale dekking van de verzekering van twaalf weken, zou eindigen.

'Zoals gezegd, hadden we ook hulp van de wijkzustur en 's nachts was er ecn nachtdienst. Na zes weken kwam de wijkzusrer ons eigenlijk belasten mer iers waarvan ik dacht: 'Ga dat ergens anders doen.' Zi жi iedere kur: 'Ik maak me ernstig zorgen over de voortgang van de nachtdienst', dic krijg ji namelijk maar 12 weken vergoed. Ik ben toen op een ochtend heel boos geworden en heb gezegd: 'Ik ga mijn energie niet verspillen aan die flauwekul.' Ik zei: 'Als die drie maanden om zijn en jullie willen ons die nachrdienst nier meer geven dan is moeder misschien wel buiten kennis en dan gaar ze maar naar ecn verplecgkliniek, als jullie dat willen.' Ja ik dacht: 'W/c doen hier alles voor het ziekenhuis, zij besparen kosten, zij hoeven helemaal niers.' Alles ded'n we zelf. Dan komt zo iemand aan je hoofd zeuren dagen achrer elkiar. (...) Ik vond ditr gezeur heel erg belastend."

Naast deze 'harde' regels van thuiszorgorganisaties of verzekeraars limiteren ook ongeschreven waarden en normen het handelen van verzorgers thuis. Bekend is bijvoorbeeld dat de reguliere geneeskunde de zogenaamde alternatieve geneeskunde over het algemeen als 'onwettig kind' beschouwt. Toch nemen patiënten met kanker, ondersteund door hun naasten, soms toevlucht tot dergelijke therapieën. Zij doen dit weloverwogen en doordacht. Het gebeurt vanuit het idee alles te doen wat mogelijk is en soms is het een deel van hun reeds lang te voren ingezetre leefwijze. Professionals nemen dit echter niet altijd serieus. Op die manier beperken ze verzorgers eveneens in hun handelen.

'Op het moment dat je te horen krijgt dat er niets meer aan te doen is, sta je met je rug tegen de muur. We waren altijd al georiënteerd geweest op de zogenaamde alternatieve tak van de gezondheidszorg. Logischerwijs kwamen we daar nu ook terecht. Mijn man en ik geloofden dat hij, voor een deel, zijn ziekte 
in de hand had en dat hij met druppels, dieet en zelfonderzoek zijn ziekteproces zou kunnen remmen. Zo reden we nog heel wat kilometers naar alternatieve therapeuten. Hij hield zich daaraan vast en voelde zich er goed bij. Hij volgde een heel streng dieet, at wel zes witte grapefruits op een dag. Het heeft ons handen vol geld gekost. Ik heb hem daarin gesteund en in zijn waarde gelaten. Dat miste ik heel erg bij de reguliere zorginstellingen. Als je kiest om in de alternatieve hoek je heil te zoeken, wordt je door de reguliere zorgverleners nier meer als volwaardig gezien. Dat vond ik heel vernederend. Je bent al zo labiel op dat moment. Je weet toch wel dat de dood uiteindelijk komt, maar je wilt gewoon iets proberen.'

Het opleggen van dergelijke regels en normen door professionals aan leken wordt ook wel de macht van de definitie genoemd ${ }^{69}$. In dit geval komt door de behandeling van kanker op een bepaalde wijze te definiëren datgene wat men niet benoemt (een alternatieve ziektebenadering) in de marge terecht. Deze uitsluiting leidt tot gevoelens van weerstand tegen diegenen die definiëren namelijk de gevestigde zorgprofessie. In deze definiëringspraktijken is per definitie geen plaats is voor zelfverwerkelijking. Disciplinering gaat altijd gepaard met vermindering of verlies van auronomie en mondigheid. Mensen worden tot leken gedegradeerd: hun competenties en capaciteiten worden gediskwalificeerd, hun percepries en definities van problemen en oplossingen ongeldig verklaard en hun mogelijkheden tor zelfbepaling en zelfbeschikking beperkt.

In het licht van dit 'gevangenschap' is het niet verwonderlijk dat sommige verzorgers naast de zorg voor een zieke een baan buitenshuis appreciëren ${ }^{70}$. Volgens verzorgers kan de combinatie van zorg en betaalde arbeid ruimte bieden. Ze halen dan uit beide sferen het beste ${ }^{71}$. Een baan is daarbij een mogelijkheid een 'eigen' 'autonoom' leven te leiden, omdat verzorgers bijvoorbeeld spanningen in een zorgrelatie tijdelijk kunnen mijden of hun gedachten buitenshuis kunnen verzetten ${ }^{72}$. Het biedt bovendien andere mogelijkheden tot het onderhouden van sociale contacten, een andere vorm van zelfrespect of andere uirdaging dan het verzorgen van een zieke geefr.

Volgens verzorgers zou het in de beginfase van de ziekte nog wel op te brengen zijn om het leven naar de wens van de patiënt en de professionals die thuis komen te schikken, maar in de loop der tijd zouden verzorgers steeds meer behoefte krijgen aan zelfstandigheid en invulling van het eigen leven ${ }^{73}$. Een verzorgster vertelt hoezeer ze tijdens de verzorging van haar man aan haar baan als docente hechtte.

'Of ik in die tijd goed les gegeven heb weet ik niet. Maar de leerlingen waren ervan op de hoogte en ik heb gedaan waarvan ik dacht dat ik het moest doen. Dan kon ik daar mijn energie weer vandaan halen om verder te gaan. (...) ja ik 
fietste weer naar school. Ik kon iets van me afzetten. (...) Mijn werk heeft zijn funcrie gehad in die tijd. Hier thuis zitren was vreselijk. We hadden nu eenmaal een relatie waarbij we elkaar in ons eigen waarde lieten. Als hij er moeite mee had gehad dan had hij me het gezegd. Maar ik zat hier in feite meestal voor nop, maar kon hem ook niet alleen laten. Hij kon het wel eens benauwd krijgen en dan moest ik er zijn. Tijdens de uren dar ik werkte kwam mijn moeder of iemand anders. Werken is daardoor eigenlijk best fijn. (...) Het is best pretrig en ik heb er energie uit gehaald. Na zijn sterfbed ben ik ook meteen weer iedere dag naar school gegaan in her begin alleen om koffie te drinken tordar ik weer met de lessen begon.'

In dit kader is het bovendien begrijpelijk dat verzorgers aan ziekenhuiszorg soms de voorkeur geven boven thuiszorg. Zorgarbeid voor terminale patiënten perkt immers de zelfstandigheid van verzorgers danig in, ziekenhuiszorg geeft die vrijheid voor een deel terug ${ }^{74}$.

'Ik vond die gang naar her ziekenhuis heel moeilijk, niemand kon meer iers, doen. Maar die verantwoording die ik thuis had, daar was ik nu vanaf. Ik spreek alleen voor mezelf. De grootste druk was er vanaf. Kijk toen ze thuis was dachr je vaak's avonds moet ik een dokter bellen of niet. In het ziekenhuis hoefde ik er alleen maar te zijn. Ze werd verzorgd. Ik was rusrig.'

Hoewel verzorgers zich enigszins schuldig voclen als zij een opname voor een patiënt overwegen en bespreken, heeft ziekenhuiszorg voor hen in bepaalde gevallen de voorkeur ${ }^{75}$.

Samenvattend omschrijven verzorgers het huis vanuit hun perspectief. Omdat verzorgers het huis waarin de zieke verblijft amper verlaten, voelen verzorgers veel beperkingen thuis. Dit verlies van 'een eigen leven' ervaren verzorgers op drie manieren, namelijk in de vorm van beperkingen in hun tijdsbesteding, de beschikking over de ruimte waar ze kunnen zijn en in hun vrijheid van handelen. Autonomie verkrijgen zij dus niet zozeer thuis, maar door aanspraak te maken op instellingen in het publieke terrein zoals het behoud van een baan buitenshuis of door de patiënt naar het ziekenhuis te laten gaan. Het huis staat voor verzorgers dus voor een inperking van hun auronomie. Tegenover het door beleidsmakers geconstrueerde huis dat staat voor autonomie en vertrouwdheid voor patiënten, zetten verzorgers een huis dat hun zelfstandigheid beperkt. 


\section{Verborgen verzorgers}

Het is logisch en begrijpelijk dat beleidsmakers complexe werkelijkheden reduceren. In nota's kan immers nier 'alles' staan. Ze construeren daarmee echter een andere en eigen werkelijkheid. Bovenstaande analyses van belangrijke concepten in het informele-zorgbeleid namelijk, 'pariënt' en 'thuis' laten zien dat die constructie een bepaalde, gender-gebonden, kleuring heeft.

Zo is op de eerste plaats duidelijk geworden dat beleidsmakers gewag maken van 'kiezende patiënten'. Ze beschrijven patiënten als autonoom handelende subjecten die goed in staat zijn over hun eigen belangen te oordelen en zeltstandig richting te geven aan hun leven. Verzorgers verschillen op twee punten in hun vertoog van beleidsmakers. Ten eerste relativeren zij de veronderstelling dat patiënten voor thuiszorg 'kiezen'. Of de verzorging thuis zal plaats vinden is volgens hen, eerder een onvermijdelijkheid dan een keuze. De plaats waar het zorgproces zich gaat afspelen zou het resultaat zijn van een samenspel van alle betrokken actoren. Verzorgers schetsen hoezeer patiënten afhankelijk zijn van de hen behandelende artsen en hun toekomstige verzorger(s) als het over de plaats van sterven gaat. Artsen vinden het min of meer vanzelfsprekend dat terminale patiënten thuis worden verzorgd, zij hebben een sociale indicatie nodig om tot opname over te gaan. Verzorgers voelen een (morele) plicht de zieke thuis te laten zijn. Patiënten willen graag naar huis. Dus worden patiënten in de laatste fase van hun leven vaak thuis verzorgd. Daarmee is in het zorgvertoog de patiënt niet langer de centrale actor, maar spelen tal van actoren mee. Verzorgers schuiven het idee dat patiënten de zorglocatie bepalen, als naïef terzijde. In hun vertoog maakt de rationcle, kiezende patiënt plaats voor een van anderen en gewoontes afhankelijk individu.

De analyse maakt op de tweede plaats duidelijk dat heleidsmakers het ziekenhuis en verpleeghuis als onpersoonlijke instituten omschrijven en ze thuis voorstellen als een vertrouwde omgeving. Een hele belangrijke functie in dat huis hebben informele verzorgers. Zonder hen kan er zelfs geen thuiszorg zijn, want zij staan bijvoorbeeld voor continuïteit in de zorg en behoeden de patiënt voor eenzaamheid. Informele verzorgers zijn dus de voorwaarde waaronder thuiszorg plaats kan vinden. Hoewel hier weinig tegen in te brengen valt, heeft een dergelijke constructie eveneens een gender-gebonden lading. Beleidsmakers behandelen verzorgers niet gelijk aan pariënten. Terwijl een patiënt autonoom zou zijn en kiest, definiëren beleidsmakers verzorgers als randvoorwaarde of als ondersteunende actoren. Ze zijn een voorwaarde voor thuiszorg, diegenen die patiënten bijstaan, zodat patiënten dat krijgen wat ze verlangen. Dit doen ze bijvoorbeeld door verzorgers te koppelen aan of te vereenzelvigen met de patiënt of door ze als 'omgevingen' te definiëren. Op deze manier maken beleidsmakers informele ver- 
zorgcrs dienstbaar en ondergeschikt aan wensen van de patiënt. In tegenstelling tot de pariënt zijn zij in het beleid niet als autonoom individu aanwezig.

Verzorgers zetten hier een ander verhaal tegenover. Ze beschrijven hoe zij, in stilre, wikken en wegen om binnen de hun gegeven (smalle) marges goede afwegingen te makin. Terwijl beleidsmakers de verzorgers amper een eigen stem geven, wordt in het vertoog van verzorgers de onzichtbare of dienstbare verzorger een mens van vlees en bloed. Dus: autonomie, zoals die door beleidsmakers aan de 'patiënt' en het 'thuis zijn' wordt toegeschreven, kan slechts ontstaan nadat ze mensen die niet autonoom zijn aan het oog onttrekken ${ }^{76}$. Thuis als plek waar autonomie voor patiënten een kans krijgt, floreert in beleid alleen dankzij de verborgen tot omgeving gereduceerde verzorgsters. 


\section{Zo mooi mogelijk}

Ik moest in die tijd een hele hoop veren laten. Zo ben ik al die maanden amper buiten geweest. Maar dat deed ik graag.

Ik heb als verpleegkundige gewerkt, daarom kon ik de verzorging alleen doen. Maar als mijn kinderen niet thuis waren geweest dan had ik het nooit gered. De laatste periode was heel erg zwaar.

Ieder van ons had een taak bij de verzorging van mijn man, het werd. snel een ritueel. Ik waste hem, zorgde voor zijn medicijnen, smeerde hem in met zalf. Hij heeft heel lang zelf zijn tanden gepoetst en zich geschoren. Dat wou hij graag. Toen hij niet meer eten kon, assisteerde mijn jongste dochter daarbij. Omdat het een zware man was hielp mijn zoon bij het tillen. Op het laatst kon mijn man niets meer zelf doen. Dat heeft hij heel erg gevonden. Zelfs bij het plassen moest hij mijn hulp hebben.

Zijn wilskracht zorgde ervoor dat hij een week voordat hij stierf nog in een stoel in de huiskamer zat. Hij wilde heel graag bij ons zijn.

Roken deed bij al lang niet meer maar toen hij wist dat hij sterven zou, is hij daar weer mee begonnen. Sigaartjes vond hij lekker. Ik vond het heerlijk dat hij daarvan genoot. Dus daar zat hij in zijn stoel, sigaartje erbij, zijn lievelingsmuziek op de achtergrond en zijn pasgeboren kleinkind in de buurt. Zalig! Al die maanden aten we rond zijn bed. We kunnen nog steeds niet aan tafel eten dat zijn we verleerd.

Het was zwaar maar we hebben het echt zo mooi mogelijk voor hem kunnen maken.

Uit een interview van een vrouw die voor haar echtgenoot zorgde 


\section{Kundige Leken}

\section{Inleiding}

Zodra her informele zorgbeleid verschijnt, onderscheiden beleidsmakers daarin verschillende typen zorg. De gezondheidszorg bestaat dan uit: professionele zorg, informele zorg en zelfzorg ${ }^{1}$. In het professionele zorgsysteem werken verzorgers tegen betaling. Ze worden omschreven als mensen die beroepshalve zorg verlenen, zoals bijvoorbeeld wijkverpleegkundigen, ziekenverzorgenden en gezinsverzorgenden. Deze verzorgers figureren in het beleid als een belangrijke groep bij het geven van zorg thuis. Informele zorg omschrijven beleidsmakers als zorg die burgers op basis van wederkerigheid geven; onberaald en spontaan. Tor deze groep behoren partners, familie, vrienden of buren van de zieke. Ook deze zorg is onmisbaar in een goed functionerend zorgsysteem. Zelfzorg, tenslotte, wordt gedefinieerd als alles wat een individu onderneemt om te bewerkstelligen dat zijn bestaan zo goed mogelijk intact blijft. Aangezien de overheid meer gemeenschapszorg wenst, zouden informele zorg en zelfzorg ten koste van professionele zorg moeten worden ingezet.

Toewijzing van professionele zorg gebeurt op basis van wat men indicatiestelling of zorgindicatie noemt. Hoewel Nederland op dit moment verschillende vormen van indiceren kent, streeft men ernaar de indicatiestelling het resultaat te laten zijn van een geformaliseerd proces waarin indicarieadviseurs onafhankelijk en op objectieve wijze de behoefte aan professionele zorg naar aard, inhoud en omvang bepalen $^{2}$. Bij zorgindicarie tracht de adviseur dus volgens een gestandaardiseerde methode vast te stellen of, hoeveel en welk type professionele zorg in die specifieke situatie nodig is.

Het indiceren van professionele zorg is afhankelijk van de inzet van informele zorg ${ }^{3}$. Want professionele zorg mag pas ingezet worden wanneer huisgenoten de als normaal beschouwde informele zorg overschrijden. Men spreekt dan over 'extra zorg' 4 . Het is de taak van de indicatieadviseur vast te stellen of daar sprake van is. 'Normale zorg' is zorg die tijdelijk van aard is, bijvoorbeeld griep of verzorging van kinderen bij kinderziekren. Hierbij is de inschakeling van professionele zorg in principe niet aan de orde. Anders ligt het wanneer het gaat om vormen van zorg die qua zwaarte, duur en intensiteit de normale zorg van huisgenoten overstijgen. Dit kan bijvoorbeeld het geval zijn, wanneer een huisgenoot chronische aandoeningen heeft of gedurende een lange periode intensieve zorg behoeft. Dat overschrijdt de grenzen van 'normale zorg'. De inzet van professionele zorg 
voor taakverlichting, ondersteuning en begeleiding van de informele zorg is dan verantwoords.

Het is niet eenvoudig te bepalen of het gaat om extra zorg. Dit is namelijk afhankelijk van uiteenlopende factoren zoals het leefpatroon van en de takverdeling binnen een gezin of de draagkracht en de normen en waarden van de informele zorg.

'Wat voor de één bovenmatige inspanning is, is voor de ander vanzelfsprekende zorg voor elkaar. Een duidelijke scheidslijn tussen normale en "extra" zorg kan dan ook niet getrokken worden. Het kan tot op zekere hoogte door na te gaan wat huisgenoten in gezinnen/leefeenheden zonder gehandicapte huisgenoten voor elkaar doen. Wat dan aan zorg modaal blijkt, kan als uitgangspunt (norm) dienen bij een vergelijking mer gezinnen/leefeenheden mer gehandicapre huisgenoten ${ }^{6}$ ?

Hoewel beleidsmakers erkennen dat het lastig is vast te stellen wat 'extra zorg' is en er bovendien van uitgaan dat informele zorg niet afdwingbaar is, stellen ze wel dat de inzer van professionele zorg alleen bij extra zorg geoorloofd is. Her geven van informele zorg is dus normaal tor het tegendeel is bewezen?

Deze procedure binnen de indicatiestelling demonstreert onder meer hoe professionele- en informele zorg afhankelijk van elkaar zijn. De informele verzorger is er voor normale zorg, de professional voor extra zorg. Beleidsmakers hebben dus opvattingen over hergeen professionele verzorgers met informele verzorgers gemeen hebben en wat ze van elkaar onderscheidt ${ }^{8}$. In dit hoofdstuk beschouw ik die laatste conventies. Centraal staat de verhouding tussen professionele zorg en informele zorg zoals in het beleid wordt verwoord. In de eerste paragraaf zal $i k$ het verschil tussen beide type verzorgers duiden. Hoe maken beleidsmakers onderscheid tussen professionele en informele zorg? Wat kenmerkt de professional en wat de leek? En welke consequenties heeft dit verschil voor hun rol? Evenals in het vorige hoofdstuk vergelijk ik deze beleidsveronderstellingen in de tweede paragraaf met die van verzorgers. In de derde paragraaf beschouw ik hun beider werkterrein of domeinen. Hoe verhouden deze zich tot elkaar? En welk gevolg heeft de beschrijving van de domeinen voor de samenwerking van professionele en informele verzorgers? In paragraaf vier zal ik wederom de conventies hierover vergelijken met ideeën van verzorgers over de verschillende werkvelden en gevolgen voor hun onderlinge verhouding. Tot slot zal ik ingaan op de uit de vergelijking voortkomende derde gender-conventie in beleid. 


\section{Professionals ondersteunen}

Beleidsmakers beschrijven drie belangrijke verschillen tussen professionele zorg en informele zorg. Het eerste verschil gaat over de vraag wie zorg geef, het rweede over de vraag waarom zorg gegeven wordt en het derde verschil hoe die zorg vorm kringt.

Op de vraag wie zorg geeft stellen beleidsmakers dat her bij informele zorg voornameliyk gaat om zorgverlening door naaste verwanten, zoals partners voor elkaar, ouders voor hun kinderen en kinderen woor hun ouders. Soms is er sprake van zorgverlening tussen buren of vrienden ". Oftewel: personen die op basis van een familieband of vriendschap zorg verlenen zijn informele verzorgers. Ze hebben een verwantschapsrelatie met de zieke. Kenmerkend voor de informele zorg is dan ook het ontbreken van een formele georganiseerde structuur van waaruit de zorg wordt verleend en de afwezigheid van het kader van een hulpverlenend beroep ${ }^{10}$. Professionele verzorgers daarentegen zijn hulpverleners met een beroepsspecifieke inbreng die gerelateerd is aan hun specifieke beroepsopleiding ". Het zijn mensen die een opleiding hebben gevolgd, daarna een werkkring hebben gevonden en in georganiseerd verband zorgarbeid verrichten. Terwijl informele verzorgers zich volgens beleidsmakers karakteriseren door een sociale relatie met de zieke en het ontbreken van een organisatorische structuur, kenmerken professionals zich door hun opleiding en georganiseerd werkverband.

Stelt men de vraag waarom informele verzorgers en professionals zorg verlenen oftewel welk motief daaraan ten grondslag ligt, dan zeggen beleidsmakers dat informele verzorgers zorg geven omdat ze verwant zijn met de zieke. Hun zorg vloeit rechtstreeks voort uit de sociale relatie. $\mathrm{Zij}$ komt voort uit gevoelens als vanzelfsprekendheid, wederkerigheid, plicht of liefde ${ }^{12}$. Professionals daarentegen geven zorg omdat ze verstand 'van zaken' hebben. Hun zorg is gebaseerd op methodisch-professionele of wetenschappelijke kennis. Professionals zouden zich zelfs dicnen te beperken tot hulp waarvoor specifieke deskundigheid nodig is ${ }^{13}$. Terwijl informele zorg dus zou berusten op nabuurschap en altruïstische morieven, zou professionele zorg gebaseerd zijn op (methodische) kennis. Deskundigheid, kennis of expertise is het demarcatiecriterium.

Tot slot de vraag hoe professionals en informele verzorgers zorg verlenen. Zoals gezegd omschrijven beleidsmakers informele zorg als spontaan en onbetaald ${ }^{14}$. Spontaan is dan gebruikt in de zin van 'vanzelfsprekend', vanzelf geleerd en ongeorganiseerd.

"In de terminale thuiszorg zal het vrijwilligerswerk in het algemeen dienen ter aanvulling c.q. ondersteuning van de spontane mantelzorg, dat wil zeggen, de partner, het gezin, familie, vrienden en buren $(\ldots)^{15}$.' 
'De hulpverlening in het kader van de rerminale thuiszorg wordt afhankelijk van de zorgbehoefte naar aard, intensiteit en tijd geboden door de omgeving (zg. spontane mantelzorg), de vrijwilligers (zgn georganiseerde mantelzorg) en de professionele hulpverleners (huisarts, wijkverpleging, gezinszorg, fysiocherapeur, maatschappelijk werk, pastor ${ }^{16}$,

'In her overgrote deel van de behoefte aan zorg voorziet de directe omgeving van de betrokkene, zonder dat daar een betaling tegenover staat ${ }^{17}$.'

'Het verlenen van mantelzorg is belastend. De mate waarin deze belasting wordt ervaren is afhankelijk van een aantal factoren, waarvan met name die op emotioneel terrein, $(\ldots)$, zwaar wegen ${ }^{18}$.

Spontane zorg betekent ook dat er geen geldelijke beloning tegenover staar, maar wel een sterke emotionele verbondenheid met de zieke ${ }^{19}$.

Volgens beleidsmakers is de manier waarop professionals zorgen te beschrijven als een merhodische, rationele werkwijze. Dit betekent dat professionele zorgverleners werken volgens een plan waarin een aantal stappen zijn te onderscheiden. De professionele zorgverlener begint met het opmerken van de zorgbehoefte, dan volgt de vraagverheldering. Deze leidt tot een diagnose en indicatie. Na het diagnosticeren stelt de zorgverlener een zorgplan op, voert het uit en evalueert gedane arbeid $^{20}$.

'Aan het proces van zorgverlening in de thuissituatie is een aantal stappen te onderscheiden:

a. opmerken zorgbehoefte en het omzetten ervan in een hulpvraag.

b. ontvangst hulpvraag, vraagverheldering

c. indicatiestelling leidend tor het opstellen van een zorgplan

d. uitvoering van het zorgplan;

e. evaluatie en zonodig bijstelling van het zorgplan ${ }^{21}$.

De professionele en universele werkwijze karakteriseert zich dus door een logische afhandeling van een aantal stappen. In tegenstelling tot de informele zorg kenmerkt professionele zorg zich volgens beleidsmakers niet door spontaniteit en emotie maar door expertise die zich uit in de vorm van methodisch, rationeel gedrag.

Op basis van voorgaande beschrijvingen trekken beleidsmakers de conclusie dat zorgprofessionals hun expertise kunnen en moeten inzetren om hiaten in de kennis van de informele verzorger te dichten. Ze moeten hun kennis overdragen. 
Dit noemen ze 'deskundigheidsbevordering van verzorgers.' Professionals zouden verzorgers voorlichting moeten geven en hun moreel en psychisch steunen ${ }^{22}$.

'Eerstelijnsmedewerkers kunnen, waar mogelijk, kennis en vaardigheden overdragen aan mensen die een beroep op hun doen $(\ldots)^{23}$.'

De informele zorg moet worden versterkt. De zelfzorg en mantelzorg kunnen worden ondersteund door voorlichting, preventie en scholing ${ }^{24}$.'

'Professionele hulpverleners dienen waar dit kan, de inschakeling van deze laatste vormen van hulp te bevorderen en kunnen daarnaast cen ondersteunende rol vervullen t.a.v. het vrijwilligerswerk in de mantelzorg ${ }^{25}$.'

De kennis van professionals zou dienen ter ondersteuning van de verzorgers. Dat is niet alleen van belang om de kwaliteit van de informele zorg te optimaliseren, maar ook omdar beleidsmakers er vanuit gaan dat informele verzorgers maximaal belast zijn en nauwelijks over voldoende uithoudingsvermogen beschikken ${ }^{26}$. De oplossing voor dit probleem moeten professionele hulpverleners brengen.

Volgens beleidsmakers dragen professionals in hoge mate bij aan een vergroting van de draagkracht van informele verzorgers ${ }^{27}$. Familieleden, vrienden, vriendinnen en buren houden het langer vol als ze weten dat ze terug kunnen vallen op de professionele zorg ${ }^{28}$.

'De eerstelijnswerkers worden geconfronteerd met veel problemen van psychosociale aard en met maatschappelijke problemen. Zij moeten personen die moeilijkheden en leed ondervinden begeleiden en opvangen ${ }^{29}$.'

'Bij professionele instellingen moet een gewillig oor zijn voor hun problemen. Daar moer erkenning en waardering zijn voor de inbreng van de mantelzorg ${ }^{30}$.'

Het beleid gaat ervan uit dat de professional de informele verzorger begeleidt en opvangt bijvoorbeeld door te luisteren naar problemen en de inbreng van de verzorgers te erkennen en te waarderen. Het instandhouden van de draagkracht van de informele zorg is een belangrijke taak voor professionele zorgverleners ${ }^{31}$.

Samenvattend is uit bovenstaande af te leiden dat beleidsmakers veronderstellen dat tegenover de expertise van de professional en diens methodische werkwijze de informele zorg staat die zich kenmerkt door een sociale relatie en emotionele binding met de zieke. Tegenover planmatig werken van de professionals staat de informele zorg die spontaan werkt. De professional krijgt een geldelijke beloning, de informele zorg nier. De professional heeft afstand, de informele verzorger is betrokken ${ }^{32}$. Op basis van bovenstaande verschillen concluderen beleids- 
makers dat professionals informele verzorgers kunnen en moeten ondersteunen. In onderstaande paragraaf komen verzorgers aan het woord over de vraag welke betekenis zij aan hun relatie met professionele verzorgers geven. Ervaren zij professionele verzorgers als hun 'ondersteuners', met andere woorden spreken ze hierover dezelfde taal als beleidsmakers?

\section{Een wederkerige relatie}

Wie alan informele verzorgers van patiënten met kanker vraagt of zij door professionals zijn gesteund, krijgt meestal een bevestigend antwoord. Zo ervaren verzorgers bijvoorbecld steun als professionals ${ }^{i 3}$ :

- hulp bij (wond)verzorging of tiltechnieken geven:

'De manier waarop ze hun werk deden, mijn man verzorgden, vond ik prima, Ze waren resoluut, maar wel betrokken.'

- hulpmiddelen regelen:

'De wijkverpleegkundige gaf onder andere opdracht tot het ophalen van een luchtbed met compressor en andere hulpstukken, zonder dat ik erom vroeg. Dat was heel plezierig.'

- zich als gast gedragen:

'Ik vond het heel fijn als de wijkverpleegkundige de badkamer netjes achter liet.'

- attent zijn:

Het was pretrig als de wijkverpleegkundige even de bloemen in de vaas schikte of ervoor zorgde dat het verschoningsmateriaal voor die middag gereed lag.'

- Luisteren naar de ervaring van verzorgers:

'In de gang vroeg de wijkverpleegkundige vaak hoe het met mij ging. Ze kon dat natuurlijk niet doen waar mijn man bij was, maar ik was blij dat ik even van me af kon praten. Zo stonden we soms wel 20 minuten bij de voordeur.'

- waardering geven voor het werk dat verzorgers verzetten:

'Het zal wel zwaar zijn voor u.'

'Past u goed op uzelf?' 
- blijk van herkenning geven:

'Mijn man, ja ik was met hem getrouwd, we hadden samen kinderen. Toch leefde hij heel erg op zichzelf. Hij was heel erg gesloten. Hij zou nier gauw wat vertellen. Het was heel vreemd toen hij ziek werd, werd hij een prater. Hij had zoveel te vertellen. Het moest er uit. Hoe kan dat zo'n verschil? Van zo'n zwijgzame man opeens...ook over de uitvaart en alles. Ik wilde zo graag weten hoe dat kon. De zuster vertelde dat ze dat vaker zag gebeuren en dat vond ik fijn.'

Naast deze vormen van steun die wellicht weinig van de zorgsituatie afhankelijk zijn, hebben informele verzorgers bij patiënten met kanker een aantal specifieke behoeften aan ondersteuning ${ }^{34}$. Ten eerste benadrukken verzorgers dat ze te maken krijgen met onzekerheid over de behandeling. Het is, inherent aan deze ziekte, vaak onduidelijk hoe het behandelingstraject er precies uit gaat zien, hoe een patiënt hierop zal reageren en wat er van de informele verzorger gevraagd gaat worden. Verzorgers zouden het liefst deze onzekerheid door professionals gereduceerd zien. Zij beschouwen de professional als iemand om hun rwijfels over ziekte en dood mee te delen.

'Je weet niet wat. er komen gaat. Hoe lang nog en wat er nog allemaal bij komt. Hij werd van een stevige gezellige man een zielig hoopje mens. Hij heeft tijden gehad dan at hij zich helemaal vol, toen at hij nog wel, maar hij kon het niet.

Op her laatst bleef er niets meer in. Ik dacht steeds dat kan zo niet en vroeg dan aan de wijkverpleegkundige hoe dat verder moest.'

Op de tweede plaats speelt angst voor de dood een grote rol in dit zorgproces. Verzorgers zien aankomen dat zij binnen niet al te lange termijn alleen komen te staan. Ze willen praten over hun eigen angst en onzekerheid. Want voor vele verzorgers is het doodgaan eng. Zullen we contact hebben tot het laatst? Hoe zal ik reageren?

'Ik was bang voor het gat. De tijd dat ik niet meer hoefde te zorgen. Dan wordt je heel erg op jezelf teruggeworpen. Er zijn zoveel mensen vandaag de dag die niet meer met sterven om kunnen gaan. Dat ervaar je pas als je ook alleen verder moet. Het was goed om daarover te praten.'

Een vrouw die eerder een partner verloren had aan de gevolgen van een hartaanval vertelt hoe ze opzag tegen het moment waarop haar tweede man dood zou zijn. Ze wilde liever na zijn dood niet bij hem blijven, want het beeld van haar eerste partner 'weggestopt in een plastic zak met een ritssluiting', stond haar nog 
teveel voor de geest. Ze was blij dat ze dit tevoren aan haar partner, de begrafenisondernemer en de wijkverpleegkundige duidelijk kon maken.

Vanaf het moment waarop verzorgers weten dat de ziekte ongeneeslijk is, is her moment waarop de ademhaling het leven zal stoppen in gedachten. Verzorgers maken zich niet alleen bezorgd om hun eigen reacrie, maar ook om die van de zieke. Zal hij pijn hebben? Bang zijn? Roepen? Of zal hij de dood vredig ingaan? Een dochter was zo blij dat haar vader het redelijk onderging en schreef dar ondanks het treurige feit dat haar vader stervende was, de band onderling erg sterk was geworden. Hierin had haar vader een groot aandeel, omdat hij ondanks het feit dat hij meestal zo gesloren was, nu zeer open mer de dood omging. Ze had fijne gesprekken met hem kunnen houden. Zijn geesteskrachr was ongeloofijk sterk. Hierover sprak zij met de professionals.

Iemand die voor een stervende zorgt is echter nier alleen bezig met het idee hoe zijzelf en de zieke op de naderende dood zullen reageren, maar heeft ook aandacht voor anderen. Kunnen vrienden van mijn man het aan? Hoe zal de familie reageren? Hoe bereid ik de kinderen voor?

'Her is een hele bijzondere ervaring voor kinderen. Ze zagen nu een hele andere man dan die ze kenden. De verpleegkundige wees me erop dat kinderen zelf wel met vragen komen. Hij adviseerde gewoon alleen die vragen heel eerlijk te beantwoorden en niet te ver uit te wijden over andere dingen, waar ze op dat moment toch geen aandacht voor hebben. Die raad hebben we opgevolgd en het bleek inderdaad te werken. De kinderen hebben het niet makkelijk gehad in die tijd, maar ik weet voor mezelf dat de oudste iets heeft meegemaakt dat hij niet snel vergeten zal. 'Mam, dood is niet eng, he?' Zo heeft hij het ervaren. Ik weer ook wel dat hij de dag na de dood van onze vriend op school riep 'Ik heb een dooie gezien.' Hij heeft afscheid van hem kunnen nemen, is ernaar toegegroeid. Hij is niet bang voor de dood.'

Een andere verzorgster vertelde in dit verband dat haar man niemand meer wilde zien. Hij weigerde alle bezoek. Ze denkt nu dat hij anderen de aanblik van zijn lijden wilde besparen. Hij beschermde daarmee zichzelf tegen de emoties van anderen. Ze was echter blij dat hij hierin duidelijk was, omdat ook zij zich zorgen maakte over de reacties van collega's, vrienden en familie. Dezelfde verzorgster vond het echter wel noodzakelijk dat haar schoonfamilie nog zou komen. Dit is dankzij de bemiddeling van zorgprofessionals gelukt. Ze voelde zich daardoor gesterkt.

'Ik ben wel heel erg aan het soebatten geweest om mijn schoonfamilie binnen te krijgen. Ze kregen weinig gelegenheid afscheid te nemen. Maar ik kreeg geen poot aan de grond bij mijn man. De wijkverpleegster kon het idee dat de familie 
maar niet meer moest komen enigszins uit $z$ n hoofd praten. Via de dokter is het echt gelukt. Hij zei: Je moet die mensen wel kans geven afscheid van je te nemen, enfin ik mocht ze toen bellen.'

Als verzorgers met professionals kunnen spreken over de onzekerheid die kanker met zich meebrengt, over bijvoorbeeld hun angst en familieperikelen, spreken ze veelal hun waardering uit over professionals en de steun die ze ten tijde van het ziekbed ontvingen ${ }^{35}$.

Opvallend daarbij is dat verzorgers in tegenstelling tot beleidsmakers niet zozeer nadruk leggen op de methodisch, technische expertise van professionals, maar vooral op een correcte bejegening. Zo noemen ze bijvoorbeeld het volgen van beleefdheidscodes (de badkarner netjes achter laten), attent zijn (materialen klaar leggen) of een simpelweg luisteren (hoe gat het met u?). In hun verhalen staat een goede relatie met de professional voorop.

Wat verzorgers onder een goede relatie verstaan, is moellijk te veralgemeniseren. Elke situatie, zo zeggen ze, heeft een geheel eigen constellatie die ook nog verandert in de tijd, bijvoorbeeld door de wijze waarop verzorgers functioneren, verwachtingen die ze bijstellen en waarden die ze belangrijk vinden. Zo kan een verzorgster op het ene moment vragen om een professional die niet dominant is, op een ander tijdstip het wederzijdse vertrouwen benadrukken een tweede verzorgster zegt dat het vooral om het nakomen van afspraken gaat.

Ia. 'Ze was zo goed, echt de stille kracht op de achtergrond'.

rb. 'We hebben, tijdens de ziekte van mijn vader, de professionele zorg als zeer positief ervaren, omdat er wederzijds een vertrouwensband ontstond.'

2. 'Her liep onderling goed omdat afspraken klopten, werden nagekomen en correct werden uitgevoerd.

Wat als steun beschouwd kan worden is volgens informele verzorgers niet zonder meer aan te geven. Terwijl beleidsmakers professionals verbinden mer kennis en methodisch handelen; de 'rationele' zijde van de zorgexpertise, verbinden verzorgers ze met ervaring en vertrouwen of de 'relationele' kant ${ }^{36}$. Desondanks roemen verzorgers de ondersteunende functie van de professional. Een steunende professional en een gesteunde verzorger is ook in hun verhalen evident.

Maar naast de beschrijving van professionele verzorgers die zich zouden kenmerken door expertise uitmondend in het bieden van steun aan informele verzorgers, geven verzorgers ook een ander, zelfs tegengesteld, beeld. 
'We hebben ook een nachtzuster gehad, ja daar was iets mee. Die hebben we na twee nachten helaas moeten afbellen. Mijn broer gaf haar instructies. Dat was niet vreemd want dat deed hij bij iedere verpleegkundige. Hij was tor 23.00 uur daar en gaf dan aanwijzingen. Dus hij zei: 'We doen het zus en zo. Die zalf voor de bips en aan de oren dat. Zo de lakens erover heen.' Maar zij deed er niets mee. 's Ochtends lag mijn moeder er nog precies hetzelfde bij. Het bed was door en door nat. Ze had gewoon niers gedaan. Die nacht daarna is mijn vader maar eens gaan kijken. Toen lag zij nog harder te slapen dan mijn moeder.'

Deze uitzonderlijke situatie maakt bijvoorbeeld duidelijk dat deze verpleegkundige het gezin, waarbij ze nachtdienst had, weinig steun bood. Aan haar expertise werd getwijfeld. Ze luisterde niet naar instructies van de zoon van de zieke vrouw, bekommerde zich nauwelijks om de zieke en lag bovendien te slapen terwijl ze waken moest. Maar de vertelster van deze gebeurtenis zegt ook dat het hier om een buitenissig geval gaat: 'er was iers mee.

Voor wie de beleidsveronderstelling dat professionals informele verzorgers steunen onder de loep neemt, is vooral de vanzelfsprekendheid waarmee de broer van de vertelster de verpleegkundige inlicht over de gang van zaken, interessant. Hij zegt: 'We doen het zus en zo. Die zalf voor de bips en aan de oren dat. Zo de lakens erover heen.' Vanuit zijn kennis en ervaring geeft de informele verzorger zorgadviezen aan de professional. Hij is geen uitzondering.

'Kijk ik had meer ervaring met dat infuus dus zei hoe ze het moesten afkoppelen.'

'Mama had veel pijn. Ik zag gewoon wanneer ze anders wilde liggen. Dat zei ik dan tegen de verpleegkundige.'

Verzorgers beweren dat professionals niet altijd zouden beschikken over meer of betere expertise dan de leken-verzorger. De informele verzorger kent de "ins- en outs' van de zieke en diens ziekte, volgens hen, soms zelfs beter dan de professional. ${ }^{37}$. Zo hebben verzorgers vaak al maanden ervaring in her zorgen en op die manier hun eigen expertise ontwikkeld.

'Dat eten geven was een hele ceremonie. Zo zitten, zulke hapjes, dit tempo. Ik deed het maar zelf want de gezinsverzorgster zag dat niet.'

'De eerste drie maanden heb ik de hele verzorging zelf gedaan. Later kwam de wijkzuster hem af en toe's morgens wassen. De rest deed ik zelf. $\mathrm{Na}$, maand kwam de zuster hem iedere ochtend wassen, zij vond dat hij zichzelf zoveel mogelijk moest aankleden. Hij kon dat toch niet, dus deed ik het maar 
of hielp ik hem. Dat deed ik want dan had hij energie om een hapje te eten of een praatje te maken.'

Terwijl deze informele verzorgsters al vele maanden de zorg voor hun partner droegen en ervaring daarmee hebben opgedaan, komen de professionals op een moment waarop al een lang zorgtraject is afgelegd. Routines over de verzorging en een 'klinische blik' voor mogelijkheden en onmogelijkheden van de patiënt zijn door deze verzorgsters ontwikkeld ${ }^{38}$. Bovendien hebben zij ook een visie op zorg. Deze blijkr in het tweede geval haaks te staan op de visie van de wijkverpleegkundige. Terwijl deze verzorgster eraan hecht dar haar man nog een sociale rol kan vervullen, wil de wijkverpleegkundige zoveel mogelijk de zelfzorg bevorderen. De verzorgster houdt aan haar zienswijze vast. De professional-leek relatie die eens gekarakteriseerd werd als een ontmoeting tussen een wetende expert en een onwetende leek beschrijven verzorgers als een ontmoeting tussen twee 'experts' ${ }^{39}$.

Behalve dat verzorgers kennis van zaken tentoonspreiden, zouden zij ook eerder het vertrouwen van de patiënt genieten dan de professional. Dit komt bijvoorbeeld omdat hun zorgvisie beter bij die van de patiënt aansluit of omdat ze van meet af aan bij een zorgtraject betrokken zijn. De patiënt uit het eerste hieronder vermelde citaat zag zijn partner bijvoorbeeld als de deskundige op het gebied van injecreren en gaf de voorkeur aan haar boven de wijkverpleegkundige. De patiënt uit het tweede citaat praat moeizaam over zijn diepste angsten. Als hij ze deelt dan is het met zijn partner. De wijkverpleegkundige weet van niets.

'De verpleegsters gaven vaak injecties, maar hij had her liefst dat ik het deed. Hij vertrouwde mij helemaal. Ik deed dat ook al heel lang (...). Dus deed ik het. Ik deed alles. Ik deed alles wat ik kon doen.'

"Weet je als je aan de vooravond van je sterfbed staat, lijkt het wel of het leven nog eens aan je voorbij trekt. Dat was bij ons in ieder geval zo. Bij mijn man kwam er een grote brok ellende uit. Hij had zo'n spanning, zo'n angst. Terwijl hij niet bang was om te sterven was hij wel bang voor het donker. Er moest altijd een lamp aan als hij ging slapen. Die geluiden die hij maakre..ik sliep boven hem. Het waren van die aardse geluiden.. Ik dacht dan waar ben je toch mee bezig...? Ik ging dan naar beneden. Hij klonk zo benauwd en dan ging ik kijken. Meestal keek hij me vragend aan. Wat ik kwam doen? Ik vroeg dan waar hij mee bezig was. Hij zei het. We praatten dan, maar niet altijd. Dat hoeft ook niet. Je hoeft niet alles met elkaar te delen. Voor mij was dit allemaal erg inspannend, er was niemand waar ik dat mee deelde, want aan de zuster vertelde hij dat niet.' 
Professionele verzorgers moeten het vertrouwen van de patiënt vaak nog winnen, zeker als het gaat over delicate kwesties als het spreken over het leven en de dood. Hierdoor hebben ze een zekere achterstand ten opzichte van de verzorger. Omdat het volgens verzorgers niet evident is dat de patiënt dit vertrouwen geeft, is steun aan hen niet vanzelfsprekend. Verzorgers suggereren dat professionals leken(verzorgsters) pas kunnen steunen op het moment dat patiënten (volledig) op professionals bouwen. Dit vraagt tijd en vertrouwen.

Tot slor zou het geregeld voorkomen dar de informele verzorgster de zorgprofessionals helpen en steunen. Denk hierbij aan het citaat waarin de broer van de vertelster de moeder verzorgt en de verpleegkundige hiervan op de hoogte stelt. Dit gebeurt bijvoorbeeld als het gaat om speciale kennis over de zieke, de specifieke uitingsvormen van de ziekte of het een typische omgang met de medicatie. Deze kennis dragen verzorgers over aan de professional. Dit heeft volgens informele verzorgers te maken met het feit dat zij aanvankelijk meer ervaring hebben mer: deze unieke zorgsituatie dan de professional. Zo vertelde een informele verzorgster dat zij de medicatie zelf regelde, een ander hoe ze de professionals schijnbaar moeiteloos toelichting gaf op her toedienen van medicijnen per infuus.

'De verzorging deed ik zelf en omdar je al snel ervaring krijgt regelde ik zelf ook de medicatie. De huisarts en wijkverpleegkundigen durfden niets met dat pompje te doen, zodat wij op een gegeven moment de wondverzorging en de instelling van het pompje ook zelf deden. Ik heb het hen uitgelegd.'

'Die flessen aan het infuus hangen deed ik dan. Alleen als er hulp was deden zij het. En ze (de patiënte) deed het zelf ook wel. Ik moet zeggen in de loop van de rijd raak je eraan gewend om dit soort dingen te doen. (...) Ik heb het veel gedaan en aan anderen duidelijk gemaakt hoe her moest.'

Naast steun bij het uitveeren van zorgvaardigheden bieden informele verzorgers ook morele sieun aan professionals. Dit doen ze bijvoorbeeld door professionele verzorgenden (figuurlijk) over de huisdrempel heen te trekken en opmerkingen te plaatsen waardoor ze hun schroom kunnen overwinnen. 'Fijn dat je er bent', 'Als je het erg druk hebt hoef je zijn nagels niet te knippen hoor.' Verzorgers steken energie in hun relatie met de professional, door ze te complimenteren of te ontzien.

'De zusters waren van die hele jonge meisjes, het was reuze moeilijk voor hen, dus ik zei maar iedere keer dat ik heel blij was dat ze kwamen.'

'De kruisvereniging wilde komen helpen. Ze kwamen dan om 10.30 uur maar meestal was hij dan al door mij verzorgd. Dan vroegen ze wat komen we hier 
doen? Ik zei dat ik het fijn vond om hem te verzorgen. Ik kon hem toch niet zo lang laten liggen?’

Verzorgers investeren dus in de relatie met de professional. Ze geven complimentjes, vragen expliciet naar de beleving van de professional of zwijgen over hun onvrede in de zorgrelatie. Volgens informele verzorgers zijn zij zelf bijzonder actief om zorgprofessionals hun werk te laten doen. In feite draaien ze de beleidsassumptic om en vertellen hoe zij op basis van hun contextuele kennis professionals ondersteuning bieden ${ }^{40}$.

Dit proces waarbij leken aan deskundigen kennis bieden over een specifieke zorgsituatie staat dicht bij het zogenoemde proto-professionaliseringsproces ${ }^{4 !}$. Staat proto-professionalisering echter voor het proces van medicalisering waarbij leken de grondbegrippen en basishoudingen van zorgprofessies overnemen, in voornoemde proces zouden professionals gedrag en unieke kennis van leken over nemen. Ik noem dit deprofessionaliseren. Het staat voor een proces waarbij professionals afwijken van standaarden en protocollen en onder auspiciën van een 'leek' inzoemen en aansluiten op de specifieke zorgsituatie. In het deprofessionaliseringsproces gaat het om het overbrengen van contextgebonden kennis van een informele verzorger op een professional op individuele en privare schaal.

Samenvattend is zorgkennis volgens verzorgers, sterk contextgebonden. De expertise van de meestal vrouwelijke zorgprofessional wordt niet zozeer bepaald doordat zij gerichte scholing heeft gevolgd en methodisch werkt, maar veel meer door de wijze waarop zij haar kennis inzet. Verzorgers vinden dat een professionele houding eerder te maken heeft met een correcte en pretrige bejegening van de verzorger en de zieke dan aan de inzet van juiste 'instrumenten'. Terwijl beleidsmakers ervan uitgaan dat professionele verzorgenden over meer expertise beschikken dan informele verzorgenden, zouden volgens verzorgers beiden over expertise beschikken. Het verschil is dat de expertise van professionals algemeen van aard is en die van verzorgers op de specifieke context is gericht. De door beleidsmakers geschetste eenzijdig ondersteunende relatie van professional naaar leek is in verhalen van verzorgers dan ook wederkerig.

\section{Gescheiden domeinen}

De verhouding tussen professionele zorg en de informele zorg is zeker bij het verschijnen van de eerste nota's over thuiszorg en informele zorg, we spreken over de jaren tachtig, niet zo eenduidig gedefinieerd als bovenstaande paragrafen wellicht doen vermoeden. In die eerste periode geven beleidsmakers professionele zorgver- 
leners namelijk enerzijds een vervangende rol ten opzichte van de informele zorg, maar anderzijds ook een aanvullende.

'(...) professionele hulpverlening zich dient te beperken tot hulp waarvoor specifieke deskundigheid nodig is, dan wel tor het overnemen van "zorgende" arbeid, indien en voor zover zelfzorg en mantelzorg of hulp van vrijwilligersorganisaries niet voldoende zijn ${ }^{42}$.'

'De professionele zorg is in deze situatie meer dan bij kortdurende zorg verantwoordelijk voor de continuïteit van de zorgverlening. Zij vormt een zwaarwegende aanvulling op de informele zorg en zal deze in voorkomende gevallen vervangen ${ }^{43}$.'

Theoretisch is dat lastig want wie spreekt over vervangen gaat ervan uit dat de actoren nagenoeg gelijk zijn, dus inwisselbaar. Wie spreekt over aanvullen legt de nadruk op het verschil in kwaliteiten van de actoren en gaat ervan uit dat de professional 'supplementaire', 'extra' zorg biedr.

Hoewel beleidsmakers de vervangende rol van professionele zorgverlener niet laten verdwijnen, trachten ze gedurende het informele-zorgbeleid steeds meer zorgtaken in handen van de informele verzorger te leggen. Zo gaat in het informele- zorgbeleid de aanvullende rol boven de vervangende prevaleren. De professional mag, zo schrijft het beleid steeds dwingender voor, de verzorger pas vervangen indien de informele verzorgers zelf, om welke reden dan ook, echt niet meer in staat zijn bepaalde taken uit te oefenen. Pas als mensen hun problemen zelf niet meer aankunnen, bestaat de mogelijkheid een beroep te doen op professionele krachten ${ }^{44}$.

'De professionele hulpverlening in de gezondheidszorg en de maatschappelijke dienstverlening is daarom aanvullend op vormen van zelfzorg ${ }^{45}$.'

'De eerstelijnszorg gezien wordt als een aanvulling op de zorg die mensen zelf of met behulp van hun omgeving aan zichzelf besteden i.c. de informele zorg ${ }^{46}$.

'Aanvullend op de informele zorg en georganiseerd vrijwilligerswerk is de zorg van professionele instellingen en personen, die zich beroepsmatig op het terrein van de thuiszorg bewegen ${ }^{47}$ '

'De professionele zorg is in de meeste gevallen aanvullend, maar onmisbaar ${ }^{48}$.'

Dat de nadruk in het beleid in toenemende mate ligt op het aanvullende karakter van professionele zorg, komt automatisch voort uit de door beleidsmakers 
gewenste vorm van de zorgpraktijk. Er is voorkeur voor onberaalde zorg in de eigen omgeving boven betaalde professionele zorg, al of niet in instellingen. Op die manier willen beleidsmakers de kwaliteit van zorg verhogen en kosten van zorg drukken. Hieruit volgt dan de stelling dat wat de informele verzorgster zelf kan doen, zij ook zelf moer doen. Alleen dat wat zij nier kan vult een professional aan.

'De thuiszorg verricht bijvoorbeeld taken die een specifieke deskundigheid vereisen die mantelzorgers niet bezitten, of ze zorgt ervoor dar her sociale systeem rond de cliënt wordt ondersteund ${ }^{49}$."

Juist omdat beleidsmakers nu stellen dat professionals de informele verzorgers aarvullen ligt de nadruk minder op overeenkomsten tussen beiden, maar meer op de verschillen.

In onderstaand citaat beschrijven beleidsmakers bijvoorbeeld de verschillende werk-domeinen van informele zorg, vrijwilligerswerk en professionals.

'Vrijwilligerswerk kan worden gedefinieerd als het werk dat in enig georganiseerd verband, onverplicht en onbetaald wordt verricht ten behoeve van anderen of de samenleving. Het wordt daarom een vorm van georganiseerde mantelzorg genoemd. (...) In de terminale thuiszorg zal het vrijwilligerswerk in het algemeen dienen ter aanvulling c.q. ondersteuning van de spontane mantelzorg, dat wil zeggen, de partner, her gezin, familie, vrienden en buren en komt daar mede niet op het terrein van de professionele hulpverlening $(\ldots)^{50}$.

Door dergelijke verschillen tussen professionele en informele zorg te benadrukken en over overeenkomsten te zwijgen maken beleidsmakers de verschillende typen zorg complementair. Zo gaat het bijvoorbeeld om aanvullende taakgebieden en kennisdomeinen. Hierdoor ontstaat het idee dat deze domeinen elkaar niet overlappen en wordt de metafoor van de gezondheidszorg als bouwdoos van subsystemen correct vormgegeven.

Een kenmerk van systeembeschrijvingen is echter dat het de nadruk legt op de afgebakende eenheden met een eigen dynamiek die mogelijkheden begrenst. Door een dergelijke beschrijving lijkr het erop alsof professionele en informele verzorgers precies weten voor welk doel ieder staat, welke invalshoek ieder benut en welke specifieke middelen ze elk voorhanden hebben. Juist hierdoor zijn tegenstrijdigheden, overlappingen en vermengingen tussen beiden in beleid minder zichtbaar. Het totale zorgmodel wordt steeds gepresenteerd als een vanzelfsprekende opeenvolging van echelons met slechts één belangrijk verschil en dat is de onvermijdelijke afname van de zelfstandigheid van de patiënt ${ }^{\text {s. }}$. 
Het complementaire karakter van de verschillende zorgtypen komt niet alleen tot uitdrukking wanneer beleidsmakers nadruk leggen op de verschillende domeinen, maar ook (en weer) als ze nadruk leggen op de verlichting die professionals informele verzorgers geven tijdens hun zorgtaak ${ }^{52}$. Professionele verzorgenden zijn volgens beleidsmakers bijvoorbeeld bij uitstek geschikt om morele steun aan informele verzorgers te bieden, zo beschreef ik ook in een voorgaande paragraaf.

'Gebleken is dat mantelzorgers her langer volhouden als zij weten dat er aandacht is voor hun positie, bijvoorbeeld door professionele hulpverleners ${ }^{3}$.'

'De commissie wijst erop dat aandacht voor de kwaliteit van leven niet slechts de patiënt betreft. Ze meent daarom dat bevordering van thuiszorg ook professionele activiteiten ten gunste van de mantelzorg moet inhouden. Naar gelang de behoefte kunnen dat praktische bijdragen zijn, (... $)^{54}$.'

Met een zekere vanzelfsprekendheid veronderstellen beleidsmakers dat een verzorger die het zelf niet redt, zich tor de professionele hulp zal wenden en dat professionele verzorgers in hoge mate bijdragen tot de vergroting van de draagkracht van de informele zorg ". Dit komt bijvoorbeeld omdat eerstelijnsmedewerkers stervenden en hun naaste verwanten ook begeleiden in psychisch-sociaal opzicht ${ }^{56}$. Met andere woorden, beleidsmakers veronderstellen dat zorg van professionals de zorg van informele verzorgers automatisch aanvult en verlicht.

Dat neemt niet weg dat beleidsmakers wel enkele eisen aan de partijen stellen. Zo wijzen ze erop dat er bereidheid tot samenwerking en communicatie tussen de betrokken professionele en niet-professionele hulpverleners in de eerstelijnsgezondheidszorg moet zijn ${ }^{57}$. Het is bijvoorbeeld noodzakelijk dat hulpverlener en hulpvrager een gemeenschappelijk doel hebben:

'Zorgverlener en hulpvrager behoren naar een gemeenschappelijk doel te streven en zullen om dat doel te bereiken - samenwerken ${ }^{58}$.'

Ook benadrukken beleidsmakers de noodzaak tot afstemming tussen verschillende zorgaanbieders. Bij zorg voor mensen met kanker in terminaal stadium zijn vaak veel professionele hulpverleners en informele verzorgers betrokken. Terwijl het in theorie logisch lijkt dat deze hulpverleners onderling communiceren en de zorg op elkaar afstemmen, blijkt dit moeilijk te zijn ${ }^{59}$. Zorgverleners die bij een zieke betrokken zijn, zouden niet altijd op de hoogte zijn van elkaars bezigheden en als ze het zijn, heeft hun samenwerking niet altijd het gewenste resultaat. Overlap, miscommunicatie en discontinuïteit in zorg zijn het gevolg. Anders gezegd: het is voor de individuele patiënt, of voor diens familie, vaak lastig een weg te vinden in het doolhof dat de zorgwereld kan zijn ${ }^{60}$. 
Een oplossing voor dit probleem, aldus beleidsmakers, is het aanstellen van een zorgcoördinator. De zorgcoördinator zou het torale zorgaanbod moeten regelen, overlap moeten voorkomen en bijhouden wie wanneer waar komt en wat doet.

'Het is nutrig en noodzakelijk dar iemand rondom de terminale patiënt de zorgverlening coördineert, dat wil zeggen zich ervoor verantwordelijk weet dar er adequate zorgverlening wordt geboden, aangepasr aan de individuele zorgbehoefte van de terminale patiënt en zijn omgeving ${ }^{61}$.'

Bovendien zou de zorgcoördinator erop toe moeten zien dat bijvoorbeeld zorg die informele verzorgers en professionele verzorgers geven, goed op elkaar aansluit en dat verzorgers op de hoogte zijn van elkaars bezigheden. De zorgcoördinator moet hiaten in de zorg voorkomen en afstemming tussen betrokkenen realiseren ${ }^{62}$.

Zorg van professionals en informele verzorgers beschrijven beleidsmakers als een overdraagbaar en cognitief geheel dat te beheersen, organiseren en af te stemmen is.

'Het: gaat erom dat mantelzorg en thuiszorg samenwerken als bondgenoten, (...). Bij intensieve thuiszorg slaagt men er alleen in de zorg te geven die nodig is als mantelzorg en professionele zorg samenwerken. Samenwerking moet voorop staan, waarbij de professionele thuisverzorgers er vooral op dienen te letten dat de mantelzorger gesteund wordt en zonodig tijdelijk ontlast. Het gaat om respectvolle samenwerking met begrip voor de eigen taak van een ieder ${ }^{63}$.

Hocwel beleidsmakers blijk geven van mogelijke afstemmingsproblemen tussen professionele en informele verzorger, gaan ze steeds uit van een gemeenschappelijk streven, her aanvullende karakter en de eigen raak van de verschillende verzorgers.

Samenvattend beschrijven beleidsmakers de verhouding tussen professionals en teken als een complementaire. Dit is terug te zien wanneer beleidsmakers de verschillende deelsystemen beschrijven, de complementaire taken belichten en oplossingen aandragen om een gemeenschappelijk streven te bewerkstelligen. De geschetste verhouding is voor beleidsmakers weinig problematisch waardoor ze een harmonisch karakter krijgt. In de volgende paragraaf zal ik verzorgers aan het woord laten over de verhouding tussen professionals en henzelf.

\section{Domeinenstrijd}

Evenals beleidsmakers schilderen informele verzorgers de verhouding tussen professionele verzorgers en henzelf af als een complementaire, harmonische relatie. 
Zeker in een eindfase van een leven hechten ze daaraan. Verzorgers zijn nog al eens, al dan niet openlijk, bezig met vragen over leven en dood, over de zin van lijden en over de betekenis die het leven van een naaste heeft gehad. Verzorgers spreken over de pretrige samenwerking met professionals. Een in gezamenlijkheid gedragen eindrraject, waar ieder een aandeel in heefr, geeft informele verzorgers van patiënten met kanker een zekere voldoening.

'Het was een hele bijzondere en mooie tijd. Iedereen wilde ook wel graag helpen en vaak gingen de verpleegkundigen daarin ook veel verder dan dat vanuit hun beroep werd gevraagd.'

'De zuster die er meestal was die was heel lief, die zei ook zelf: 'wat hebben jullie een lieve moeder, wat een lief mens.' Ze deed er ook alles voor. Als ze kwam dan keek ze meteen of alles goed zat; de catheter, het matje droog. Laken erover heen. Wij hielden het in de gaten als ze weg was.'

Hoewel informele verzorgers positief zijn over hun relatie met professionals, laten ze in hun verhalen regelijk enkele moeilijkheden zien. Zo vertelde een verzorgster dat de samenwerking tussen haar en de professionele verzorgenden niet vanzelf ging. Achteraf vraagt ze zich af of ze nogmaals een dergelijk traject in zou gaan, zegt ze dat het heel zwaar was en geeft ze aan heel veel geduld en kracht nodig te hebben gehad.

'Kijk her was iedere keer afwachten, dan weer dit en dan weer dat. Ik heb nooit geweten dar er zoveel bij kwam kijken. Soms vroeg ik iets, bijvoorbeeld over de vergoedingen. Niemand gaf antwoord en uiteindelijk moest ik er zelf weer achter aan. Dan maakte de verpleegkundige zich weer heel druk over de weekendhulp, terwijl ik dat zelf nog wel kon. Het was steeds zoeken en afstemmen, wat doe ik en wat jij en wat wil ik en jij. Nee ik dacht dat ze meer konden doen. Het was echr zwaar.'

Mensen zorgen zoals ze leven. Sommige veraorgers verwachten daarbij veel hulp en kant en klare oplossingen. Ze zijn teleurgesteld als dat niet het geval blijkt te zijn. Anderen verwachten dat een samenwerking vanzelf gaat of dat verzorgers aanvoelen wat nodig is. In tijden van ziekenverpleging thuis is het crisistijd waarbij sommige rourines worden doorbroken, mar anderen blijven bestaan. Wonden worden in tijden van hoogspanning zichtbaar, nieuwe blessures worden opgelopen. Beleidsmakers gaan er dan wel van uit dat het werk van de professional dat van de verzorger probleemloos aanvult, maar de zorgarbeid gaat door ook als hun onderlinge spanning stijgt. 
Overigens vinden informele verzorgers het moeilijk punten waarover onenigheid tussen professionals en henzelf bestond te noemen. Ze zijn mild in hun oordeel over de beroepskrachten en het lijkt alsof ze de verplegende of verzorgende nier af willen vallen. Ze nemen het op voor de verpleegkundigen als ze zeggen dat zij het te druk hebben. Of uiten hun ongenoegens over de samenwerking in bedekte termen en zeggen bijvoorbeeld dat het 'niet aan de wijkverpleegkundige lag, maar aan de uitvoering.'

'De zuster was vol goede bedoelingen, de uirvoering in de prakrijk echter niet zo zinvol. Voor ons niet, voor Henk zelf ook niet. Hij ergerde zich zelfs aan hun vragen en voorstellen.'

Ilk wil geen kwaad woord zeggen over de medewerkers van de thuiszorg. Die thuiszorg is in principe allemaal goed; wijkverpleging, gezinszorg, nachtzorg. Alleen ja, we moesten ons wel steeds aanpassen aan hun tijden en gewoontes.'

Deze citaten beginnen met waardering voor de professionals, maar daarna volgt toch kritiek op geleverde kwaliteit. Dit tekent de ambivalente verhouding van de verzorger ten opzichte van de professional. Enerzijds zijn verzorgers afhankelijk van professionals, anderzijds willen ze zoveel mogelijk autonomie behouden en bijvoorbeeld hun ideeën over (goede) zorg niet terzijde schuiven. Hoe deze ideeën tor onderhandelingen nopen, verzorgers vragen concessies te doen of compromissen te sluiten, werk ik in drie thema's uit. Ik beschrijf daarbij ook welk werk informele verzorgers verzetten wanneer ze de onderhandelingen met professionele verzorgers aangaan om de voor hen evidente overlappingen en spanningen in deze relatie te slechten.

\section{HEI GEVECHT OM DE AUTONOMIE}

Het inroepen van professionele zorg brengt voor informele verzorgers per definitie verlies aan privacy en autonomie mee ${ }^{64}$. Aanvankelijk staan informele verzorgers dan ook weifelend, zo niet huiverig tegenover de inmenging van professionals in hun zorgpraktijk ${ }^{65}$. Informele verzorgers vinden het moeilijk afhankelijk te worden en hulp van derden te accepteren. Ze hechten aan de beslotenheid van de zorgsituatie.

'Ik vond het moeilijk al die hulp te krijgen. Je zit al in zo'n nare siruatie en je wordt ook nog eens extreem afhankelijk.'

'Wij hadden afgesproken alles zoveel mogelijk zelf te doen en ons huis niet te laten overspoelen met hulpverleners.' 
'Ik heb geen instanties ingeschakeld, de reden is dat hier veel wijkverpleegkundigen werken. Dus in enkele maanden heb je teveel mensen over de vloer.'

'In de tijd van de chemokuur kreeg ik heel. wat mensen en hulpverleners over de vloer. Ik vond dat vreselijk, vreselijk.'

Informele verzorgers definiëren, zeker bij aanvang van hun zorgrelatie tot de professionals niet in termen van welwillendheid en complementariteit, maar in termen van onwilligheid en strijd. Verzorgers beschouwen professionals aanvankelijk als orde-verstorende personen, indringers en privacy-schenders.

'Die professionals, ja ik heb een dubbel gevoel. Aan de ene kant gaf het wel verlichting. Ik stond er niet meer zo alleen voor. Maar aan de andere kant zag ik ze als indringers. Ook vond ik het zwak van mezelf dat ik ze nodig had. Ik kon dat maar moeilijk overgeven en accepteren.'

'Ik vond het heel erg toen de wijkverpleegkundigen kwamen, ja het was echt een teer punt, dan geef je iets over he?' Je doet afstand van iets. (...) Ik gaf iers over aan een ander dat ik zelf had willen doen, maar ik kon het niet. Het was voor mij cen stap terug, maar dat gesol met hem kon ik ook niet meer aan.'

Wijkverpleegkundigen bieden hun diensten soms eerder aan, maar raken deze maar moeizaam kwijt ${ }^{66}$.

'Van het Groene Kruis kwamen ze twee maal per week mijn schoonmoeder wassen. Die woonde in de woning beneden ons, dan kwamen ze wel even naar boven, vragen of ze konden helpen. Maar ik wou nier dat ze ons kwamen helpen. Mijn man en ik vonden het prettiger als ik het deed. Dat zei hij niet met zoveel woorden maar hij liet het wel merken.'

Omdat verzorgers professionals als indringers beschouwen gaan ze in de hoop takkverlichting te krijgen en tot onvrede van professionele zorginstanties pas over op de hulp van professionals als zijzelf de zorg echt niet meer kunnen dragen.

Ook als de professionele verzorgenden eenmaal binnen zijn is een spanning tussen professionele en informele verzorgers merkbaar. Dit komt bijvoorbeeld tot uirdrukking wanneer informele verzorgenden duidelijke ideeën hebben over het te voeren zorgbeleid en die ideeën haaks staan op die van de zorgprofessional. Een verzorgster geeft een voorbeeld en zegt:

'Wij hebben ervoor gekozen om naast het bed dat in de kamer stond een

kamerscherm neer te zetren, daar kreeg ik van de wijkverpleging veel weerstand tegen. Ze vond het geen goed. idee. Maar ik vond het zelf wel goed. Als wij in de 
voorkamer met elkaar bezig waren dan kon oma als ze toch al moe was zich even rerug trekken. Ik ken haar. Ze had een eigen plekje.'

De functie van een kamerscherm in het ziekenhuis wordt door de informele verzorgster getransleerd naar haar huis. Dan ontstaat de opmerkelijke situatie dat de verpleegkundige, in het verlengde van her overheidsbeleid, een pleidooi houdt voor de patiënt die gediend zou zijn bij een volledige incorporatie in het gezin. De informele verzorgster pleit, in de overtuiging van het feit dat zij weet wat oma wil, daarentegen voor oma's privacy en die van haar gezin. Opmerkelijk hierbij is dat de wijkverpleegkundige in haar zorgvisie zieke en omgeving eenvoudig samenvoegt. De verzorgster pleit echter voor een scheiding tussen die actoren. De ideeën van informele en professionele verzorgers over de vraag wat goede zorg is botsen en dit geeft strijd omdat de professional de verzorgster zou dwingen te denken in algemene 'professionele' termen ${ }^{67}$.

Terugkerende gevoelens van onbehagen en ontevredenheid over de noodzaak tot het aanpassen aan professionele normen gedurende zorgsituaties maken de vanzelfsprekende complementaire relatie, vanuit het perspectief van de informele verzorger, twijfelachtig. Dit geldt, zoals getoond voordat professionals het woonhuis betreden, tijdens de verzorging van de zieke en tot slot ook na overlijden van de patiënt.

'Na de dood van Henk nam de wijkverpleegkundige contacr mer ons op. Als vorm van nazorg, denk ik, kwam ze langs om te praten. Het gevoel wat ik al eerder had werd nu weer bevestigd. Ze wist zich geen raad met de siruatie. Eerlijk gezegd denk ik dat ze bang was om zo dicht met kanker bij een jong iemand in aanraking te komen. Nee steun was dat niet.'

'De wijkverpleegkundige kwam na de dood nog wel eens koffie drinken. Dat vond ze gezellig. Dan ging ze maar weer. Ik had daar eigenlijk niet zo'n behoefte aan. Net als die groepjes, die ze me adviseerde, dat lotgenotencontact. Het is goed dat ze er zijn, maar ik pas daar niet.'

In bovenstaande voorbeelden gaan de professionals ervan uit dat nazorg in de vorm van een gesprek over de ervaring met het ziekbed en de dood een zinvolle afronding is van het gezamenlijke zorgproces. Zo sluiten zij gewoonlijk hun zorgproces af. De beide informele verzorgers geven echter te kennen hier niet voor te voclen. De ene omdat zij het idee had dat de professionele verzorgster zelf nog veel te verwerken had, de andere omdat de door de professional geopperde adviezen niet bij de verzorgster pasten. Juist vanwege deze verschillende perspecrieven en ideeën van waaruit informele verzorgers en professionals naar eenzelfde 
zorgsituatie kijken is het, op diverse tijdstippen en in diverse situaties, moeilijk tot een gezamenlijke definitie van de zorgsituatie te komen ${ }^{68}$.

\section{DE STRIJ TEGEN DE BUREAUCRATIE}

Als informele verzorgers vertellen over verschillende en botsende opvattingen of zich beklagen over gebrek aan ondersteuning van professionele verzorgers, dient dit gezien te worden in het spanningsveld waarin de zorgprofessional haar vak uitoefent. Enerzijds vraagt het management van zorgorganisaties professionals te werken in een zorgorganisatie met eigen bureaucratische regels. Anderzijds vraagt men hen de uniciteit van de patiënt of het cliëntsysteem serieus te nemen. Instituren zoals zorgorganisaties opereren dankzij een stelsel van generaliseerbare regels. Ze geven, volgens eigen zeggen, ook 'zorg op maat'. Het is aan de professional binnen een bureaucratische organisatie deze maatzorg te bieden.

Professionele verzorgenden dienen enerzijds tegemoet te komen aan de wensen van de organisatie en anderzijds aan de wensen van hun 'cliënt'. Een voorbeeld waarin beide wensen botsten, vertelt een verzorgster:

'Er stond een bepaalde tijd voor het lenen van her bed van het Groene Kruis. We kregen, drie dagen voor het overlijden van mijn moeder, een telefoontje of we dat bed nog langer nodig hadden. Dat vond ik zo gênant. Ik dacht hoe halen jullie het in je bovenkamer. De wijkzuster was toen hier. Ze gaf die man door de telefoon antwoord en zei terwijl mijn moeder dat hoorde en daar zo lag: 'Nou dat duurt niet meer zo lang. Dat heeft me enorm gestoord.' 、

De verantwoordelijke voor de uitleen van materialen belde naar de informele verzorgster met de vraag of het bed op korte termijn beschikbaar kwam. Voor de informele verzorgster was de uitleentermijn van dit bed echter een futiliteit in vergelijking tot het stervensproces van haar moeder. Ze stoorde zich aan de vraag. Ze irriteerde zich bovendien aan de wijkverpleegkundige die hardop zei dat de patiënte niet lang meer te leven had. De wijkverpleegkundige bevond zich in deze situatie letterlijk tussen een vraag van haar organisatie en de zorg voor haar cleënten. Gaf ze de organisatie antwoord, dan zou ze haar cliënten hiermee te kort doen, dacht ze alleen aan de beleving voor de cliënt, dan bleef ze in gebreke tegenover haar werkgever. Een dergelijk voorval toont het spanningsveld tussen een vraag van de organisatie en een vraag van de informele verzorger.

Tot ongenoegen van verzorgers zijn professionals niet alleen gebonden aan regels over de uirleen van materialen, maar ook aan voorschriften over hun aanwezigheid in het huis van de zieke. In sommige plaatsen geldt bij de gezinsverzorging 
bijwoorbeeld de regel dat een verzorgende niet alleen in het huis van de pariënt magr zïn.

'De gezinsverzorgster kwam rwee ochtenden per week. Terwijl zij er was, kon ik mooi even boodschapjes doen. Maar zij mocht niet alleen in huis zijn.'

Veel zorgorganisaties stellen dat de wijkverpleegkundige de patiën hooguit drie maal daags mag bezoeken.

'Ik had natuurlijk her woordeel dat ik met medicijnen om kon gaan (vezzorgster is drogist). I $k$ heb her allemaal zelf gedaan, ook met de pijnpomp toentertijd.

Dar ging dag en nacht door en als je daar een wijkverpleegster voor moet laten komen dan is dat een probleem.'

Deze regels staan volgens informele verzorgers een vanzelfsprekende aanvulling cq. samenwerking in de weg en geven voor de informele verzorger spanning tijdens de zorgarbeid.

Hoewel informele verzorgers begrip tonen voor de professionals, die zich (ook) naar deze regels moeten schikken, zijn er weinig positieve woorden voor het management van de zorgorganisatie.

'Die mensen die hier kwamen wilden best wel, maar die leiding, die organisatie. Ik dacht vaak: waar blijft de menselijkheid.'

'Het zijn papieren organisaties. Voor de nachthulp is bijna 44 dagen overlegd en getelefoneerd. Toen het bijna rond was, was het niet meer nodig.'

'Er was een weinig flexibele opstelling van het kruiswerk, het was geen zorg op maat. Je was steeds afhankelijk van hun normen, van de tijd dat zij langs konden komen.'

Volgens verzorgers maken regels zoals over nachthulp of bezoekrecht de zorg onpersoonlijk, inadequaat en inflexibel. Dit maakt het moeilijk een vertrouwensband met professionals op te bouwen, terwijl die essenticel zou zijn.

'Ja toen kwam de nieuwe gezinsverzorgster, dat was een complere Barbiepop.

Een plaatje om te zien hoor, met een wolk parfum om haar heen. Daar werd je misselijk van. Tijdens de chemokuur heb ik menigmaal moeten vragen of ze een ander luchrje op wilde doen. Ze werd er doodmisselijk van. Door de oppervlakkige gesprekken, die ik mer haar had, hoorde ik wel dat ze een paar maanden daarvoor nog achter de kassa zat. Ik ben daar heel kwaad over geweest. Ik begrijp niet dat ze in een gezin waar een jonge vrouw met twee jonge kinderen ernstig kanker heeft, zo iemand neerzetten. Toen ben ik maar met haar 
gaan praten, als een soort maatschappelijk werkster. Van: zeg luister eens, ik merk dat je het hier moeilijk hebr.'

Deze informele verzorgster bijvoorbeeld ageerde tegen het feit dat de gezinsverzorgende zich geen raad wist met de situatie. Volgens haar 'was er niet gezocht naar de juiste persoon voor de juiste plek.' Dan zier ze het als haar taak het gedrag van de gezinsverzorgster in de juiste banen te leiden. Zij gaat een gesprek aan om de gezinsverzorgster te ondersteunen. Dat gaf spanning, want haar verwachting was anders. Ook een andere verzorgster vertelt welke keerzijde het krijgen van hulp uit een grote zorgorganisatie heeft en welke inspanning dat van haar vroeg.

'Bij de wijk hadden we vreselijk veel verschillende gezichten. Bijna iedere dag een andere zuster. Alleen de avondploeg was tamelijk stabiel, want ze hadden daar een roulatiesysteem. De ene week hadden we 's avonds die en de andere week die. Dat wisten we. Overdag was het meestal een verrassing wie er kwam en hoe laat. Dat was niet zo erg, behalve toen ik iemand kreeg die voor de wasbeurt kwam. Hij stond daar zo van wat zal ik eens doen. Toen heb ik zelf de wasbeurt gedaan en de wijkverpleegkundige heeft het bakje water bij de kraan gehaald. De rollen waren toen even omgekeerd. Dat was natuurlijk te gek. Kijk een wasbeurt is intiem, het is al niet pretrig dat zovelen je bloot zien, maar zo iemand daar heb je niks aan.'

De verzorgster vertelde hoe flexibel zij moest zijn. Zo moest ze keer op keer afwachten welke professional er zou komen om haar grootmoeder te verzorgen. Bovendien varieerde het tijdstip waarop deze kwam. Volgens deze verzorgster zou door de inzer van zoveel verschillende krachten het meest wezenlijke van zorg verloren gaan. Zorgverlenen zou intrinsiek intiem zijn en daarom individueel gericht ${ }^{69}$.

In beide gevallen laten de verzorgsters zien hoe zij zelf arbeid verzetten om de brug naar de bureaucratic te slechten. In het eerste geval ging de informele verzorgster in gesprek met de gezinsverzorgende en peilde ze haar gevoelens. In het tweede geval stelde de verzorgster zich Hexibel op en komt het zelfs zover dat ze zelf de wasbeurt geeft en de wijkverpleegkundige assisteert. Dergelijke voorbeelden geven aan dat informele verzorgers arbeid verzetten om binnen de regels van de zorghureaucratie gewenste zorg te krijgen. Over deze arbeid zwijgt het beleid.

Volgens informele verzorgers moeten de professionals door hun organisaties veel meer in staat gesteld worden om ambiguïteit en instabiliteit te tolereren, om aan veranderende behoeften van de zorgvrager tegemoet te komen. Verzorgers stellen het op prijs als professionals zodanig denken en handelen dat ze aan individuele wensen tegemoet kunnen komen. Dit betekent dat ze de professional vragen om 
de zorgvraag vanuit het insiders-perspectief te begrijpen en de generaliseerbare kennis en regels eigenlijk alleen te beschouwen als een gids voor het handelen. Pas wanneer het zorgspel minder is gereglementeerd, kan zorg een zaak zijn van betrokkenheid, handelingen en emotie in plaats van cijfers, regels en papier. In dat geval zou volgens informele verzorgers pas sprake zijn van een aanvullende, harmonische relatie.

\section{ONDERHANDELEN OVER DE ROL VAN DE VERZORGER}

Wanneer informele verzorgers hun relatie tot de professionele verzorgers als een moeizame relatie definiëren, komt dit niet alleen voort uit een verlies aan autonomie of de spanning tussen bureaucratie, standaardisering en uniciteit. Verzorgers zijn niet alleen druk doende enige zeggingskracht te behouden en algemeen geldende regels toepasbaar te maken voor hun situatie, zij zijn ook in onderhandeling over de manier waarop professionals hen benaderen en bejegenen namelijk als medehulpverlener cq. partner of als pariënt ${ }^{70}$.

Zorgorganisaties vragen aan hun professionals voor beide gezichten van de verzorger oog te webben. Zo vragen professionals aan de ene kant maximale inzet van verzorgers, maar aan de andere kant moeten ze ook oog hebben voor hun draagkracht. Ondat de professional in dit spaningsveld moet opereren, is een harmonische situatie niet vanzelfsprekend, maar zal de verzorger werk verzetten (ook) deze spanning te stechten.

Indien de professional een yerzorger benadert als partner in de zorg kunnen zich volgens verzorgers verschillende lastige situaties voordoen. Zo kan het zijn dat professionals ervan uitgaan dat verzorgers partners zijn, terwijl de verzorger dit niet zo ziet. Een verzorgster vertelde hoezeer bij voorbaat rekening werd gehouden met de zorg die zij en haar zussen zouden bieden.

'Het ging steeds slechter met moeder. De kanker grocide door, Op haar buik kwam een enorm gerwel dat openbrak.

Wij, de zussen, hadden al die tijd al heel veel opgevangen.

We waren alle middagen en avonden daar er als het nodig was ook 's nachts.

Dat deden we allemaal terwijl we ook nog werkten en een eigen gezin hadden.

Daarom wilden we na enkele maanden graag gezinshulp. Tijdens het intake gesprek werd ons gevraagd of er kinderen zijn: dochters en schoondochters. la, we waren met drie zussen. Ze dachten natuurlijk drie vrouwen, die kunnen veel zelf doen. We deden ook heel veel.

Uiteindelijk hadden we recht op drie middagen gezinshalp. Dat kwam ons weer slecht uit, de middagen vulden we immers zelf al op. 's Morgens hadden we hulp nodig. Pas na russenkomst van de huisarts kon dat geregeld worden.' 
Deze verzorgster was het niet eens met het uitgangspunt dat zij en haar zussen op het moment dat er professionele hulp komt, dezelfde hoeveelheid zorg blijven geven. 'We deden al zoveel.' Zij was het er pertinent niet mee eens dat de professional haar en haar zussen als mede-hulpverleners beschouwde. Ze zag zichzelf als 'patiënt' en wilde verlichting van haar taak.

Een andere moeilijkheid doet zich voor wanneer professionals verzorgers zeggen hen als medehulpverlener te beschouwen, maar hun gedrag daar niet naar is. In werksituaties waar ieder een aandeel heeft in her totaalproces is het gebruikelijk dat er overleg plaatsvindt. Volgens verzorgers is dat niet altijd het geval. Verzorgers zeggen bijvoorbeeld moeite te hebben om een deel van de zorg af te staan. Een verzorgster vertelde dat ze gewend was haar man lichamelijk te verzorgen en dat ze moeite had dit door de wijkverpleegkundige over te laten nemen. 'Het was alsof ik faalde.' Voor de wijkverpleegkundige was het vanzelfsprekend dat zij de patiënt voortaan zou wassen. De verzorgster liet dat toe. Achteraf heeft ze het betreurd dit uit handen te hebben gegeven. Ze zei: 'Ik had liever iedere dag dat half uur gehad om met de wijkverpleegkundige te praten dan dat ze de zorg aan mijn man overnam.' Dus een professional die een verzorger benadert als partner in de zorg doet er, volgens verzorgers, goed aan serieuze werkbesprekingen te houden.

Niet alleen de situatie waarin informele verzorgers vanzelfsprekend ingezer worden als bondgenoot van de professional kan spanningen geven, ook diagnoses of interventies die niet aansluiten bij de beleving van de verzorgster kunnen aanleiding zijn voor enige ergernis.

'De verpleegkundige zei dat het niet goed met me ging. Ik vond dat gezien de omstandigheden meevallen. Ze zei ook steeds dat ik erover praten moest. Maar ik had daar in het geheel geen behoefte aan. Dus laat je dat soort adviezen maar van je afglijden'.

Terwijl de professional de verzorgster beschouwd als 'patiënt' deelt de verzorgster deze mening niet. Ze ziet dan ook geen heil in de voorgestelde gesprekken. De verzorgster beschouwd zichzelf niet als patiënt.

Indien de professional de informele verzorger ongewenst als 'patiënt' benadert kunnen zich drie mogelijke discrepanties voordoen ${ }^{71}$. a. De informele verzorger ziet zichzelf niet als overbelast, terwijl de professional wel tekenen ziet. Dit zou in bovenstaand citaat het geval kunnen zijn. Mogelijk zag de wijkverpleegkundige tekenen van overbelasting en wilde zij, door het aanmoedigen over de zorg te praten, de verzorgster steunen. b. Informele verzorgers wensen geen psychologische steun terwijl professionals menen dat ze dit wel nodig hebben. Eerder citeerde ik een verzorgster die geen belang had bij de zogenaamde nazorg na de dood van haar man. De wijkverpleegkundige kwam na de dood om te praten terwijl de 
verzorgster daar geen behoefte aan had. c. Informele verzorgers krijgen hulp, maar voelen zich daarmee niet geholpen. Zo schreef een verzorgster:

'Natuurlijk was het fijn dat de zuster kwam voor de verzorging, maar ik had meer aan iemand gehad die af en toe eens oppaste zodat ik weg kon gaan.'

'Ik weet wel dat er rouwverwerkings- en praatgroepen zijn, maar niet iedereen wil zijn verdriet in de grote groep gooien. De zuster heeft me dar wel vijf keer gezegd. Ik had mijn baan en daar kon ik veel in kwijt.'

Mannelijke verzorgers zijn eerder geneigd zich op te stellen als partner - medehulpverlener, maar professionele verzorgers zien hen eerder als patiënt ${ }^{72}$. Vrouwelijke mantelzorgers daarentegen spreken openlijker over de last van de verzorging, maar professionals spreken hen meer aan op hun partnerschap in de zorg. Dus de benadering van de informele verzorger als partner of als patiënt kan niet alleen tot misvatringen leiden, maar is ook aan sekse gebonden.

Samenvattend vertellen verzorgers hoe er in huis over verschillende punten spanningen kunnen ontstaan russen professionals en verzorgers. Zo is er voor, tijdens en na het ziekbed 'strijd' over de vraag wat goede zorg is, vechten de verzorgers voortdurend tegen de bureaucratie en tot slor zijn ze in onderhandeling over de manier waarop zij bejegend willen worden. Dit vraagt veel energie en arbeid van verzorgers. Terwijl beleidsmakers de verschillende domeinen als complementair zien en daarmee een harmonieuze relatie neerzetten, laten verzorgers zien dat en hoe beide type verzorgers zeggenschap claimen, oftewel waar de gemeenschappelijkheid in hun takenpakket zit. Naast de in het beleid geschetste complementaire, harmonieuze relatie tussen professionals en leken zetten verzorgers een relatie waarin spanningen evident zijn.

\section{Kundige leken}

Hoe verhoudt professionele zorg zich tot informele zorg? Dat was de beginvraag van dit hoofdstuk. Door een vergelijking van conventies in het zorgbeleid over deze verhouding met conventies in verhalen van verzorgers, kwamen verschillen en overeenkomsten tussen beide vertogen aan het licht. Beleidsmakers construeren een zorgsysteem waarin professionele verzorgenden enerzijds een hiërarchisch, superieure positie ten opzichte van de informele verzorgers innemen en anderzijds harmonisch met informele verzorgers omgaan. Dit is op het eerste gezicht wellicht merkwaardig. Hiërarchie is per definitie verbonden met macht terwijl harmonie geassocieerd wordt met gelijkwaardigheid. Deze ambiguïteit in de definiëring van 
de verhouding tussen verzorgers thuis is echter terug te voeren op hit systeemdenken waar extramuralisatie van zorg op stoelt (zie hoofdstuk twee). Hierin vormen beschreven zorgsystemen weliswaar een opeenstapeling van delen, maar toch en juist daardoor een naadloos geheel; een harmonische hiërarchie.

De hiërarchische positie ontlenen professionals hoofdzakelijk aan de in hun opleiding opgedane kennis en methodische werkwijze. Hierdoor kunnen zij, in tegenstelling tot de verzorgers, vanuit organisatorisch verband werken, hebben ze meer afstand en krijgen betaald voor hun diensten. Dit alles maakt dat professionals in staat zijn de informele verzorgers te begeleiden, op te vangen en te ondersteunen. Mer deze veronderstelling creëren beleidsmakers een eenzijdige afhankelijkheid. Omdat merhodische kennis, ondersteunend vermogen en het geven van waardering uitsluitend aan eén partij, namelijk de professionals toevalt, construeren beleidsmakers een relatie waarbij verzorgers ondergeschikt zijn aan professionals. Beleidsmakers stellen dat verzorgers het beter redden met professionele hulp, waarmee ze de kracht, maar ook een zekere superioriteit van professionele verzorgers impliceren.

De hiërarchische relatie tussen professionele en informele zorg beschrijven beleidsmakers ook als een harmonische. Dit doen ze door enkel de verschillen tussen informele en professionele zorg te benadrukken. Zo beschrijven ze hun verschillende domeinen in het zorgsysteem en verschil in activiteiten, waarbij ze er van uitgaan dat de professional doet wat de informele zorg niet kan en vice versa. De belangrijkste activiteit die de professional van de leek onderscheidt is het geven van (educatieve of emotionele) steun. Hiermee construeren beleidsmakers niet alleen de complementariteit, maar bovendien een zekere affectiviteit tussen de professional en de leek ${ }^{73}$. En juist omdat beleidsmakers verschil en affectie benadrukken en over overeenkomsten en spanningen tussen professionele en informele verzorgers zwijgen, kan hun relarie een harmonische zijn.

De belcidsconventie dat professionals over een zodanige expertise beschikken dat ze verzorgers kunnen ondersteunen, vond ik ook bij verzorgers terug. $\mathrm{Zij}$ hebben echter een andere opvarting over de waarde van deze expertise. Deze zou niet zozeer ontleend worden aan de gevolgde opleiding dan wel aan het feit of de professional in staat is haar expertise over te brengen en toe te passen in een specifieke situatie. Wie over expertise beschikt en wat juiste kennis is kan volgens verzorgers niet a priori worden vastgelegd. Dientengevolge plaatsen verzorgers professionals niet automatisch in een superieure positie. Vanuit de perceptie van informele verzorgers is de beleidsaanname dat professionele verzorgers beschikken over relevante expertise waardoor juist zij leken-verzorgers kunnen ondersteunen te eenvoudig en eenzijdig. 
Volgens informele verzorgers is hun eigen experrise, ook wel ervaringskennis genoemd, evenzeer van belang om goede zorg te verlenen. Bovendien maakt het proces, waarin verzorgers voortdurend onderhandelen met professionals, duidelijk dat het minder eenvoudig te duiden is dan beleidsmakers doen voorkomen wie het primaat op kennis heeft, wie onderricht of wie steunt. Zodoende zetten informele verzorgers, in tegenstelling tor het beleid, niet zozeer een hiërarchische verhouding tussen professionele zorg en informele zorg neer, maar een gelijkwaardige wederkerige relatie, waarin wederzijdse afhankelijkheid voorop staat. De in her beleid geconstrueerde hiërarchische relatie is in verhalen van verzorgers gelijkwaardig.

Ook de beleidsconventie dat het om een harmonische verhouding tussen professionele -, en informele zorg gaat, vergeleek ik met uitspraken van verzorgers hierover. Dan blijkt dat verzorgers niet alleen het idee bevestigen dat zorgpartijen aanvullend werken, maar tevens dat er spanningen zijn. Er vinden voortdurend onderhandelingen plaats. Verzorgers hechten aan hun autonomie: praten over hun zienswijze, overtuigen, buigen algemene regels om naar voor hen acceptabele normen of proberen regels te ontduiken. Ze protesteren tegen beslissingen over de inzet van zorg, uiten hun woede door brieven te schrijven of laten derden bemiddelen. Over deze voor verzorgers essentiële aspecten van zorg thuis wordt in het zorgbeleid gezwegen. Beleidsmakers gaan uit van een onproblematische samenwerking en ontkennen op die manier een wezenlijk deel van de zorgarbeid van verzorgers, namelijk dat deel waarin ze aan een relatie met professionals werken en zich inzetten opdat professionals bij hun thuis zorg kunnen leveren.

Doordat beleidsmakers onderhandelingen over zorgsituaties nier tot de arbeid van (informele) verzorgers rekenen, negeren ze een deel van hun werk. Hierdoor ontstaat een dominant vertoog dat een deel van zorgarbeid van verzorgers, namelijk dar waarin ze voortdurend onderhandelen negeert. Met andere woorden: een zorgbeleid dat de verhouding informele verzorger en professionele verzorger afschildert als een relatie die vanzelfsprekend complementair is, vreedzaam verloopt en waarin saamhorigheid overheerst, belicht volgens verzorgers, slechts één kant van de zorg-medaille. Volgens hen zit er ook een wezenlijke andere kant aan een zorgrelatic. Hun verhalen kenmerken zich niet alleen door het schetsen van harmonieuze taferelen, maar zij beschrijven verschillende spanningsvelden. Deze manifesteren zich voor, tijdens en na het ziekbed. Over dit strijdtoneel in huis spreken beleidsmakers niet. Thuis en wat zich daar afspeelt is, volgens verzorgers, geen veilige haven in een woelige wereld, maar een afspiegeling van de woeligheid daarbuiten.

Door de deconstructie van de twee bovenstaande beleidsveronderstellingen (hiërarchie en harmonie) omtrent de verhouding tussen professionele en infor- 
mele verzorgers blijkt dat het op het eerste gezicht onschuldig onderscheiden van professionele zorg en informele zorg geen gender-neutrale activiteit is. Een derde gender-conventie komt aan het licht. Naast het problematiseren van zorgarbeid, het marginaliseren van verzorgers, dat in vorige hoofdstukken is beschreven, betoog ik nu dat beleidsmakers professionals in een hiërarchische, harmonische positie ten opzichte van de verzorgers plaatsen en daarmee een wezenlijk deel van de zorgarbeid van informele verzorgers ontkennen. 



\section{Gevangenen der Liefde}

Wat wij zo moeilijk vonden, waren de regels. We moesten dit en mochten dat. Ja dat viel ons tegen. Je roept toch pas hulp in als het echt niet anders gaat?

Neem nou die nachthulp... het is werkelijk schandalig. Je hebt maar recht op een vergoeding voor zes weken nachthulp. Maar wie weet nou wanneer de laatste zes weken ingaan? Zelfs de huisarts kon het niet zeggen. We bleven dat maar uitstellen ten koste van onszelf.

En toen de nachthulp er eenmaal was, waren het zenuwslopende tijden. Aan de ene kant waren we blij met de nachten waarin moeder zich wat beter voelde, maar tevens was er angst dat ze langer zou leven en ons dan hulp afgenomen werd.

Vanuit ons oogpunt bekeken vond ik dat we niet veel hulp hadden gehad. In hoogtijdagen en dat was al laat in het proces, vijf ochtenden wassen en drie dagdelen hulp, de rest deden we zelf. Alleen op het laatst die nachten....

Waar gaat het eigenlijk om? Om die zes weken of dat iemand rustig dood kan gaan?

Zorg op maat? Dat geloof ik wel, de vraag is met wiens maat men meet!

Uit een interview van een dochter die voor haar moeder zorgde 


\title{
5. Georganiseerde Liefde
}

\author{
If community care means anything it means that responsibility is placed \\ as near tot the individual and his carer as possible.
}

\section{Inleiding}

Dir proefschrift is ontstaan uit verwondering over het paradoxale karakter van het informele-zorgbeleid. Informele zorg staat immers voor zorg die ongeorganiseerd is, die mensen onbetaald verlenen en die haar oorsprong heeft in sociale relaties. Als beleidsmakers informele zorg in beleid vatten, lijkt het dan ook alsof ze het hart uit die zorg wegnemen. Door het formuleren van beleid over informele zorg wordt die zorg geformaliseerd.

Is dit alles wat over dit beleid te zeggen is? Nee. Er gebeurt meer. Als beleidsmakers informele zorg aanmoedigen, definiëren ze, wellicht onbedoeld, ook wat goede zorg is en hoe een informele verzorger zich behoort op te stellen om een succesvol verzorger te zijn. Om dit specifieke en normatieve karakter van het informele zorgbeleid bloot te leggen stelde ik de vraag welke conventies beleidsmakers produceren.

Om antwoord op deze vraag te krijgen voerde ik een analyse uit van beleidsplannen over thuiszorg en informele zorg. De doelstelling van deze studie was de beleidsconventies in kaart te brengen en na te gaan wat de betekenis hiervan is voor de prakrijk van de informele zorg. Zo is bijvoorbeeld duidelijk geworden dat het beleid veronderstelt dat de informele zorg zal afnemen, dat pariënten een keuze hebben waar ze zullen sterven en dat professionele verzorgenden over meer expertise beschikken dan informeel verzorgenden. Het opsporen van dergelijke conventies heeft inzicht gegeven in de waardegebondenheid van het informele zorgbeleid.

In dit proefschrift is speciale andacht geweest voor gender-conventies. Daarbij verwijst gender naar de mannelijke en vrouwelijke sekse en in dit proefschrift vooral naar waarden die daarmee verbonden zijn. In het tweede hoofdstuk heb ik bijvoorbeeld duidelijk gemaakt dat het informele zorgbeleid de verantwoordelijkheid voor zorg in hoofdzaak bij vrouwen legt. Daarom worden juist vrouwen die de arbeidsmarkt betreden, als probleem gedefinieerd. Bovendien besteden beleidsmakers aan de onvolkomenheden in de zorg van vrouwen meer aandacht dan aan datgene dat (al jarenlang) goed gaat, waardoor vooral het problematische karakter van informele zorg in de schijnwerpers komt. Terwijl beleidsmakers aanvanke- 
lijk startten om verzorgers als ideaal en onmisbaar deel van het zorgsysteem te beschrijven, verbinden ze hen in het huidige zorgbeleid vooral met de plicht tor zorgen en hun tekortkomingen daarin. In hoofdstuk 3 beschreef ik hoe beleidsmakers aan informele verzorgers andere (gendergebonden) kwaliteiten toekennen dan aan pariënten. Terwijl ze de locatie waar informele verzorgers werken, 'de thuissituatie', sterk opwaarderen, geldr deze waardering in mindere mate voor de verlener van informele zorg. Natuurlijk onderkennen beleidsmakers het belang van verzorgers. De analyse laat echter zien dat waarden die beleidsmakers voor patiënten erg belangrijk achten, zoals keuzevrijheid en autonomie, voor en bij verzorgers amper een rol spelen. Deze a-symmetrie in de behandeling van patiënt en verzorger in beleid vormt een tweede gender-conventie van het informele zorgbeleid. Hoofdstuk 4, tot slot, beschrijft hoe het beleid verzorgers in vergelijking tot professionals marginaliseert. Dit gebeurt enerzijds door professionele verzorgers hoger in de hiërarchie van het zorgsysteem te plaatsen, anderzijds door kennis en activiteiten van verzorgers in beleid nauwelijks te vermelden. Hierdoor verbinden beleidsmakers professionals met kennis, rationaliteit, methodiek en afstand. Terwijl ze bij verzorgers de koppeling maken met ervaring, emotie, intuïrie en nabijheid. Op basis hiervan wordt in beleid gesteld dat professionals verzorgers moeten steunen waardoor ze verzorgers (eenzijdig) afhankelijk maken van professionals.

Omdat er geen uitgewerkt analysekader voorhanden was, om dergelijke conventies bloot te leggen is dat in de voorgaande hoofdstukken ontwikkeld. Ik heb naast het beleidsvertoog over informele zorg, twee andere vertogen geplaatst, te weten het wetenschappelijk vertoog over informele zorg en het vertoog van verzorgers zelf. Deze gingen als het ware met elkaar in dialoog. Een vergelijking werd mogelijk. De analyse van de verschillen tussen de vertogen maakt de vaak vanzelfsprekende en daardoor moeilijk traceerbare beleidsconventies zichtbaar. Door een vergelijking van conventies in beleid met andere conventies werd duidelijk welke impliciete boodschap het beleid heeft, oftewel, hoe gender-conventies het informele zorgbeleid schragen. Bovendien maakt zo'n analyse duidelijk hoe de vertogen op elkaar inwerken; hoe zij overeenkomen. En dat geeft inzicht in de mate waarin conventies cultureel ingebed zijn; 'harder' of 'zachter' zijn. Wanneer een veronderstelling bijvoorbeeld in alle drie de vertogen voorkomt is deze maarschappelijk meer aanvaard dan wanneer ze slechts in één vertoog bestaat. De conventie is dan 'harder'. En hoe harder de conventie des te moeilijker ze te veranderen is. De culturele inbedding geeft dus een indicatie voor de mate waarin een conventie ter discussie kan worden gesteld.

Goede bedoelingen van beleidsmakers voorkomen niet dat er een zorgpraktijk ontstaat waarin (gender)conventies worden ge(re)produceerd. Want (ook) de 
beleidstaal is voorgevormd; beleidsteksten zijn interteksten en dragen dus ideeën en conventies van eerdere en andere taalgebruikers. Daar valt niet helemaal aan te ontsnappen. Toch geeft diezelfde taal beleidsmakers ook ruimte voor het doorbreken van stereotiepe conventies die bijvoorbeeld huidige gender-beelden bevestigen ${ }^{2}$.Zo zouden beleidsmakers er vanuit kunnen gaan dat het aantal verzorgers, ondanks toenemende arbeidsmarktparriciparie van vrouwen, stabiel blijft. Ook zouden ze uit kunnen gaan van een afhankelijke in plaats van autonome pariënt of van een gelijkwaardige in plaats van hiërarchische relatie tussen professionele en informele verzorger. Deze alternatieve vertellingen kunnen ze bij wetenschappers, maar zeker bij verzorgers halen. Dit is echter niet het geval.

In dit hoofdstuk zal ik recapituleren welk specifieke beleidsverhaal over informele zorg wordt verteld, welke waarden daarbij in het geding zijn en nagaan welke betekenis de daarin verborgen (gender)conventies hebben voor de positie en de praktijk van informele verzorgers. In de volgende paragraaf vergelijk ik de verschillende vertogen met elkaar waardoor ik het specifieke van het beleidsverhaal kan belichten. In de derde en vierde paragraaf diep ik de betekenis van dit verhaal verder uit door enkele ondersteunende maatregelen voor verzorgers onder de loep te nemen. Dit dient als voorbeeld om te laten zien wat het voor verzorgers betekent nu beleidsmakers een specifieke taal bezigen en (gender)conventies (re)produceren. Omdat de beleidsmatige aandacht voor informele zorg aan de ene kant en de rationalisering van die zorg aan de andere, te plaatsen is binnen een grotere maatschappelijke beweging cq. intertekst, ook wel bekend onder de naam 'managementisme', zal ik die samenhang in de vijfde paragraaf demonstreren. Tot slot kom ik in de laatste paragraaf van dit proefschrift terug op de in het eerste hoofdstuk opgeworpen vragen. Ik laat zien wat de recente bemoeienis van beleidsmakers met informele zorg voor de configuraties tussen de overheid en burgers betekent. Oftewel wat de gecreëerde informele zorgpraktijk voor de verhouding tussen publieke instellingen en her privare zorgdomein inhoudt. Anders gezegd: Hoe is met de bemoeienis van de overheid de informele zorg getransformeerd? Wat betekent het voor informele verzorgers nu beleidsmakers in hun prakrijk interveniëren?

\section{Verdwenen relaties}

In voorafgaande hoofdstukken zijn drie vertogen beschreven. In het beleidsvertoog maakt informele zorg voornamelijk onderdeel uit van een groter zorgsysteem. Dit bestaat uit verschillende echelons, de zogenaamde tweedelijns-zorg, eerstelijns-zorg, informele zorg en zelfzorg. Deze lijnen verwijzen steeds naar 
andere locaties zoals bijvoorbeeld: (gespecialiseerde) klinieken, thuiszorginstellingen en huizen van burgers. Door opname in het zorgsysteem krijgen informele verzorgers en de plaats waar zij hun werk verrichten officiële waardering, dat wil zeggen dat zij erkend worden als onmisbaar deel van het zorgsysteem. Bovendien krijgt informele zorg bepaalde kwaliteiten toebedeeld: informele zorg is goedkoop, kwalitatief beter en meer toegesneden op wensen van patiënten dan professionele zorg. Beleidsmakers vrezen echter dat een toenemend aantal vrouwen her geven van informele zorg verruilt tegen buitenhuiselijke arbeid. Hierdoor zal het aantal verzorgers dalen en dit brengt het voortbestaan van het systeem in gevaar. Hoewe] beleidsmakers menen dat het opleggen van een zorgplicht ontoelaatbaar is, laat dit onverlet dat gebruik gemaakt kan en moet worden van de mogelijke beschikbare informele zorg ${ }^{3}$. De aandacht voor informele zorg is in dit vertoog vooral verbonden met de toekomst van de totale gezondheidszorg en specifiek met de vraag of er voldoende verzorgers zullen zijn. In dit verroog staat informele zorg voor een belangrijk onderdeel van een groter systeem.

In het wetenschappelijk vertoog is informele zorg niet zozeer een onderdeel van een zorgsysteem, maar staat het meer voor individuele arbeid. Onderzoekers beschrijven of meten de zorgarbeid van informele verzorgers door dit op te splitsen in taken, handelingen of activiteiten. Zo is informele zorg verbonden met wassen, gesprekken voeren, administratie doen etc. Vrouwen verrichten, zo is dan de conclusie, meer zorgarbeid dan mannen, ze houden zich in ieder geval meer bezig met intieme handelingen. Dit betekent dat zorgarbeid, die veelal thuis plaats vindt, gelijksoortige aandacht krijgt als vormen van buitenshuis verrichte arbeid. De arbeid die verzorgers verrichten is inzichtelijk gemaakt. Tegelijk met deze erkenning komt de constatering dat draaglast en draagkracht van informele verzorgers vaak niet in balans zijn. Wetenschappelijke studies over zorgarbeid en gevolgen voor medicijngebruik, stress en burn-out zijn talrijk. Mannen houden zich weliswaar met andere taken bezig dan vrouwen, voor beiden geldt dat het verlenen van informele zorg belastend is. Tegen de verwachting in gaan vrouwen meer gebukt onder het verlenen van zorg dan mannen. Kortom: de meeste onderzoekers constateren een overbelasting van verzorgers en dragen oplossingen hiervoor aan. Daardoor is de aandacht voor informele zorg in dit vertoog vooral verbonden met (andere vormen van) arbeid en de gevolgen die dat voor de 'arbeiders' in dir geval verzorgers kan hebben.

Wanneer verzorgers zich uitdrukken over informele zorg gaat het over unieke dagelijkse belevenissen. In dit vertoog is informele zorg verbonden met waarden als vanzelfsprekendheid, plicht, verdriet of woede. De beschrijving van informele zorg staat veelal in het teken van ambivalenties. Typerend zijn bijvoorbeeld zowel vreugdevolle als pijnlijke ervaringen, gelijktijdige gevoelens van tevredenheid en 
deceptie over eigen kunnen of over de samenwerking informele en professionele verzorgenden. In tegenstelling tot de andere vertogen doet het er in dit vertoog minder toe dat het vooral vrouwen zijn die zorgen, al speelt af en toe wel teleurstelling over her feit dat mannen zich minder lijken in te zetten dan vrouwen van ze verwachten. Het verloop van relaties tussen betrokkenen is belangrijker dan het man-vrouw verschil. Voor de uiteindelijke beoordeling van de zorg is het van essentieel belang hoe de relatie tussen zieke en verzorger, tussen informele verzorgers onderling en de relatie tussen informele verzorger en professional is geweest. In dit vertoog is informele zorg dus vooral besproken in het licht van (zorg)relaties tussen mensen.

In de verschillende vertogen is het spreken over informele zorg verbonden met andere kwesties. Het beleidsvertoog brengt informele zorg in verband met het gezondheidszorgsysteem, her wetenschappelijk vertoog verbindt informele zorg aan arbeid. Verzorgers zelf bespreken informele zorg in het licht van sociale relaties.

Een ander opvallend verschil tussen de vertogen betreft de centrale actoren. Zo is in het beleidsvertoog de patiënt de belangrijkste actor. Het pleidooi voor thuiszorg, informele zorg en steun voor informele verzorgers gebeurt in naam van de patiënt die graag thuis wil sterven. Ook her huis is gepercipieerd als een plaats waar het voor de patiënt goed toeven is. Hij heeft hier autonomie, kan sociale contacten onderhouden en op alle tijden aandacht krijgen. Daartoe wordt de omgang tussen professionals en informele verzorgers thuis harmonieus verbeeld. In het wetenschappelijk vertoog is de (informele) verzorger thuis de belangrijkste actor. Onderzoekers beschouwen informele verzorgers als interessant onderzoeksobject omdat hun arbeid, juist vanwege het private karakter, amper in kaart was gebracht. Als onderzoekers publiceren over ondersteuning in de vorm van kennis of professionele begeleiding van informele verzorgers, is dat primair in her licht van de zwaarte van hun zorgarbeid. In het vertoog van verzorgers, ten slotte, spelen opvallend veel actoren een rol. Wie precies de hoofdrol heeft is dan ook moeilijk te duiden. De verzorger is het in ieder geval niet. Dit komt bijvoorbeeld tot uiting wanneer verzorgers vertellen hoe onvermijdelijk het is dat ze thuis voor de patiënt zijn gaan zorgen. De pressie daartoe is groot. Soms is de patiënt thuis en is her heel vanzelfsprekend dat hij daar blijft. Een andere keer zeggen artsen in het ziekenhuis niets meer voor de patiënt te kunnen doen; een medische indicatie voor opname is er dan niet meer. Als de patiënt te kennen geeft naar huis te willen, lijkt er geen ontkomen aan. Hoewel verzorgers wel afwegingen maken of ze de patiënt thuis willen verzorgen is het antwoord hierop, vanwege de situatie zoals die zich aandient, bijna altijd ja. Als het zorgproces thuis in gang is gezet, komen vervolgens professionele verzorgenden het huis in. Met hun kennis over zorgsi- 
tuaties helpen ze de zieke en nemen ze regels vanuit hun zorgorganisaties mee. Ook nu is niet duidelijk wie de hoofdrol speelt. Dus: in het verhaal van verzorgers staat niet slechts één actor, maar staan dynamische relaties tussen mensen en hun onderlinge afhankelijkheden centraal.

Samengevat: in het beleid staan verzorgers anvankelijk als deel van een zorgsysteem waarin de patiënt centraal staat. Later hebben beleidsmakers ook oog voor de individuele verzorgsters omdar deze gebukt gaan onder hun arbeid. Hierdoor kunnen ze het voortbestaan van het zorgsysteem in gevaar brengen. De verzorgster is echter steeds verbonden met andere actoren; ze is ofwel gekoppeld aan de wens, wil en autonomie van de patiënt of staat onder deskundige begeleiding van professionals. Op die manier verlopen zorgprocessen in beleid harmonisch. In het licht van het doel informele zorg te bevorderen is dit een begrijpelijk en zelfs logisch verhaal. De alternatieve vertellingen tonen dat het ook anders had kunnen zijn. Zo zou het beleid consequent de wens van verzorgers in het beleid centraal kunnen zetten, de nadruk kunnen leggen op de afhankelijkheidsrelatie tussen zieke en verzorger en/of de relatie tussen professional en verzorger als een wederkerige verbeelden. Aangezien het beleid veelal uitgaat van 'de pariënt', 'autonome subjecten' en 'hiërarchie' is de beleidsvertelling (gender)specifiek. Wat betekent zo'n gender-specifieke beleidsvertelling voor de praktijk van de informele zorg?

\section{Overbelaste verzorgers}

Hoewel er verschillen zijn tussen de vertogen, is in alle vertogen de (dreigende) overbelasting van verzorgers als probleem gedefinieerd. Zo stellen beleidsmakers dat overbelasting van informele zorg, vanwege de bedreiging van het zorgsysteem, een wezenlijk probleem is en dat dit probleem door demografische en maatschappelijke ontwikkelingen waarschijnlijk in ernst en omvang toe zal nemen ${ }^{4}$.In het wetenschappelijk vertoog start men het onderzoek vaak vanuit de vraag welke gevolgen het verrichten van zorgarbeid heeft om te concluderen dat dit bijvoorbeeld kan leiden tot fysieke of psychische oververmoeidheid, depressiviteit, een hoog medicijngebruik, gebrek aan vrije tijd, financiële zorgen en vereenzaming ${ }^{5}$.Informele zorgarbeid is volgens onderzoekers zware arbeid. Ook verzorgers vertellen dat her geven van zorg weliswaar een aangename ervaring kan zijn, maar eveneens belastend is. Die last komt alleen al voort uit het besef dat een geliefd iemand dood zal gaan. Verder geven verzorgers discrepanties aan tussen dat wat ze gewenst hadden te bieden en dat wat ze in werkelijkheid presteren, tussen de wens van de zieke en die van henzelf of tussen informele zorg en professionele zorg. 
Bovendien voelen ze spanning omdat ze hun huidige leven en toekomst anders hadden voorgesteld dan deze er met een zieke naast zich, uitziet.

In het licht van eerder genoemde verschillen tussen de vertogen is her niet verwonderlijk dat bij het oplossen van dit probleem, het geven van steun aan verzorgers, andere accenten worden gelegd. In de beleidswereld is de vraag om steun in hoofdzaak verbonden met de veronderstelling dat de overbelasting op de totale populatie in ernst en omvang zal toenemen. Dit is een ontwikkeling die het streven naar meer en betere thuiszorg in gevaar brengt ${ }^{6}$. Daarom zoeken beleidsmakers naar oplossingen op collectief niveau. Zo wordt als oplossing voor het toetreden van vrouwen op de arbeidmarkt, gesuggereerd dat mannen meer bij het geven van informele zorg ingeschakeld moeten worden. Tegelijk zouden vrouwen en mannen die zorgen moeten blijven zorgen en met dit doel zijn ook verschillende beleidsondersteunende maatregelen geïntroduceerd. Deze moeten ertoe bijdragen dat de bereidheid tot het verlenen van informele zorg niet alleen toeneemt, maar ze moeten ook het potentieel optimaliseren ${ }^{7}$. Beleidsmakers steunen informele verzorgers dus vooral omdar de kwantiteit van her zorgpotentieel gelijk moet blijven.

Onderzockers pleiten ook voor steun aan informele verzorgers. Deze steun is erop gericht de individuele arbeid zo pretrig mogelijk te laten verlopen want zorgarbeid, zo is hier de aanname, kan even als andere vormen van arbeid een bedreiging voor de individuele gezondheid zijn. Zo zijn er ideeën om een meetinstrument voor het opsporen van onder andere risico's op stress of psychische overbelasting in werksituaties om te bouwen tor een instrument voor het meten van arbeidsomstandigheden bij informele verzorgers ${ }^{8}$. Behalve her ontwikkelen van instrumenten om (zorg)arbeidsomstandigheden te meten, geven onderzoekers ook suggesties om individuele verzorgers te ondersteunen. Deze suggesties zijn talrijk en variëren van mogelijkheden om technische hulpmiddelen bij de zorg in te zetten tor het inschakelen van steungroepen. Dat wil niet zeggen dat onderzoekers het eens zijn over de meest wenselijke vorm van steun. Bij patiënten met kanker bijvoorbeeld zou $50 \%$ van de partners van deze patiënten ernstige problemen hebben, die variëren van uitputting, depressie of spanningen door relatieproblemen ${ }^{9}$. Terwijl de ene onderzoeker bijvoorbeeld pleit voor speciale steungroepen zou de ander dit overbodig vinden en de ondersteunende rol van de huisarts willen optimaliseren ${ }^{10}$. Onderzoekers pleiten dus voor ondersteunende maatregelen, vanuit het idee dat ziekte als gevolg van zorgarbeid voorkomen moet worden. Zij willen vooral de individuele zorgarbeid en de gevolgen hiervan voor het welzijn en de gezondheid van verzorgers optimaliseren.

Verzorgers tenslotte vragen ook om steun. Ze willen vooral goed omgaan met de ambivalenties die hun situatie zo kenmerkt. Zo willen ze aan de ene kant de 
wens van de patiënt thuis te sterven respecteren, aan de andere kant hun recht op een eigen leven niet opgeven. Ze zijn aan de ene kant blij met de steun van professionals, aan de andere kant vinden ze het moeilijk zich naar hun regels te moeren schikken. Juist al die tegenstrijdigheden worden beschouwd als oorzaak voor het feit dat het geven van zorg aan stervende mensen thuis zo'n ingewikkelde, stressvolle ervaring is. Een ondersteuningsvorm, in welke vorm dan ook, is voor hen het meest zinvol als deze het unieke en ambivalente karakter van dit zorgproces serieus neemt. Verzorgers kunnen in hun praktijk dan ook niet zoveel met algemene regels of maatregelen. Natuurlijk vraagt zorg thuis, ook volgens hen, om enige organisatie. $\mathrm{Zij}$ vragen echter om een flexibele houding ten aanzien van standaarden en regels, omdat een bureaucratische opstelling van professionals en starheid bij de toepassing van regels voor hen extra werk met zich meebrengt. Dat professionals hen bejegenen als mensen in een onvergelijkelijke omstandigheid is voor hen van essentieel belang. Kortom ondersteunende maatregelen die verzorgers voorstellen zijn erop gericht unieke zorgprocessen tussen mensen zorgvuldig te laten verlopen.

Hoewel de verschillende vertogen andere accenten leggen om de informele verzorgers te steunen, lijkt aan de veronderstelling dat informele verzorgers steun nodig hebben nauwelijks te tornen. De taal waarmee beleidsmakers, werenschappers of verzorgers zich hierover uitdrukken verschilt echter. Beleidsmakers stimuleren verzorgers omdar deze krachien onmisbaar zouden zijn in her totale zorgsysteem. Als resultaat van de ondersteuning hebben ze een goed deelsysteem voor ogen. Daarom spreken zij hoofdzakelijk in 'sociaal politieke' termen. Ze spreken verzorgers aan als burgers en wijzen op hun plicht een bijdrage te leveren aan het torale zorgsysteem ". Wetenschappers pleiten ook voor steun aan verzorgers zodat zij hun zorgarbeid kunnen dragen. Het resultaat van de door hun voorgestelde interventie is een persoon die voldoende draagkracht heeft. Zij drukken zich uit in een 'psychologische' taal en spreken verzorgers aan als patiënten, geven adviezen om hun gezondheid en welzijn re behouden. Verzorgers, tor slot, willen graag procesgerichte steun die past bij het unieke en contingente van hun zorgsituatic. De door hun voorgestelde interventies moeten leiden tot afname van spanningen bijvoorbeeld tussen informele en professionele verzorgers. Zij drukken zich vooral uit in een 'romantisch' vocabulaire. Waarbij het gaat om de erkenning van hun uniciteit, ambiguïteit, om communicatic, empathie en persoonlijke aandacht. Kortom: hoewel in alle vertogen de conventie dat verzorgers steun nodig hebben te vinden is, heeft men verschillende vocabulaires om over (steun aan) informele zorg te spreken ${ }^{12}$. Hoe verhouden deze talen zich tot elkaar en wat is de betekenis van de beleidstaal voor verzorgers? 


\section{Professionaliseren van informele zorg}

In beleid gebruikr men aanvankelijk vooral sociaal politiek vocabulaire waarbij verzorgers gewezen worden op hun burgelijke plicht. Toen verzorgers in het beleid een plaats kregen, werden hun kwaliteiten geëxpliciteerd en deden beleidsmakers een beroep op hen om van die kwaliteiten gebruik te maken. Omdar her gezondheidszorgbestel gebaat zou zijn bij een sterk informeel zorgsysteem kregen beleidsmakers (later) ook oog voor de noden van verzorgers. Hoewel dit in het licht van het behoud van her zorgsysteem begrijpelijk is, spreken beleidsmakers verzorgers door de speciale aandacht die in beleid uitgaat naar hun klachten niet alleen meer aan als burger, maar evenzeer als patiënt. Want behalve dat ze verzorgers aansporen te zorgen, formuleren ze hun rechten daarbij. Deze zijn vertaald in verschillende vormen van steun opdat de draagkracht van verzorgers gehandhaafd blijfr ${ }^{13}$.Naast de verzorger als 'goede burger' kwam de verzorger als 'tweede patiënt' te staan ${ }^{14}$. Op die manier ontstond een beleidsvertoog waarin sociaal-politiek en psychologische taalgebruik samengaan.

Dit invloedrijke taalgebruik waarin de verzorger zowel beschouwd wordt als burger en patiënt maakt dat verzorgers in een lastige positie verkeren. Wie een verzorger aanspreekt als burger zal bijvoorbeeld uitgaan van draagkracht, kennis en autonomie. Wie een verzorger daarentegen beschouwt als een patiënt zal draaglast, onwetendheid en afhankelijkheid voorop zetten. Stel dat een indicatieadviseur thuiskomt bij de verzorger en de zieke. Gaat het om een indicatieadviseur die de 'verzorgster/burger' aanspreekt dan zal ze haar zoveel mogelijk inzetten bij de zorg voor de zieke, zal ervanuit gaan dat juist zij weet wat goed is voor een patiënt en deze verzorgster behoeden voor al te veel bemoeienis van buitenaf. Een indicatieadviseur die uitgaat van de 'verzorgster/patiënt' zal haar zoveel mogelijk ontzien, zal ervanuit gaan dat ze hulp van buitenaf nodig heeft en zoveel mogelijk professionele diensten aanbieden. Natuurlijk is zo'n benadering hyporheriseh. Toch geeft het wel het spanningsveld weer waarin verzorgers zich bevinden.

Zeker zo opmerkelijk is dat met het gebruik van een 'sociaal/politiek' en 'psychologisch' beleidsvocabulaire tegelijk een andere zorgdefinitic naar de achtergrond schuift. Dit is de definitie van informele zorg die past bij het zogenoemde 'romantische' vocabulaire waarin die zorg beschouwd wordt als een (unicke) contingente sociale relatie. Wat het voor verzorgers betekent nu deze definitie van zorg weinig in beleidsdocumenten staat, werk ik uit aan de hand van enkele beleidsinterventies ter ondersteuning van verzorgers.

Verzorgers, zo stelt het beleid, ondervinden zowel op financieel, sociaal, lichamelijk als psychisch vlak moeilijkheden. Omdat het zorgsysteem gehandhaafd moet blijven en informele verzorgers daarvoor nodig zijn, komt het beleid hen hierin 
tegemoet. Zo willen beleidsmakers verzorgers bijvoorbeeld steunen door ze te betalen. Dit kan vanuit het zogenoemde 'persoons-gebonden budget'. Met het instellen van dit budget kan een patiënt zorg inkopen. De hoogte van het budget stellen medewerkers van het verbindingskantoor van de AWBZ vast op basis van een advies van de (gemeentelijke) indicatiecommissie. De veronderstelling is dat op die manier de patiënt vrijheid heeft om die zorg in te kopen die hij nodig denkt te hebben en dat hij dankzij het persoonsgebonden budget minder aangewezen is op reguliere instellingen. Ook kan de patiënt zijn verzorger; partner, schoondochter of buurvrouw betalen voor geleverde diensten. Dit kan een positief gevolg hebben voor de onderlinge relatie bijvoorbeeld omdat het de relatie tussen zieke en verzorger gelijkwaardiger maakt ${ }^{\text {is }}$. De informele verzorger komt dan als het ware in dienst van de patiënt. Ze wordt door beleidsmakers aangesproken als 'burger' die recht heeft op betaling voor geleverde diensten.

Een rweede ondersteuningsvorm meer gericht op het sociale aspect van zorg zijn bijvoorbeeld cursussen, waarvan ik de Rationeel Emotieve Training (RET) als voorbeeld neem. Hoewel een gering percentage verzorgers dergelijke cursussen volgt, propageren beleidsmakers deze. Informele verzorgers zouden, zo is het idee, vanwege hun emotionele betrokkenheid bij de verzorgde moeilijk hun zorgraak kunnen volbrengen. Oftewel: hun betrokkenheid en emotie staan het leveren van goede zorg in de weg. Daarom zouden verzorgers kunnen leren om hun emotionele benadering plaats te laten maken voor een meer rationele benadering. De cursussen bieden hier handvatten voor. Het doel daarvan is dat verzorgers 'intimiteit op afstand' creëren en zo los komen van historisch gegroeide verhoudingen. Verzorgers dienen daartoe hun zorgtaak meer rationeel en minder emotioneel te gaan benaderen en daarom moeten ze reële gevoelens van irreële leren te onderscheiden. Hoewel RET verschillende praktijkvormen kent, komt de kern op het volgende neer. Een idee is rationeel:

- Wanneer her gebaseerd is op de objectieve werkelijkheid.

- Wanneer het iemand helpt langer te leven of zijn of haar doelstellingen te verwezenlijken.

- Wanneer het nare en ongewenste gevoelens bij iemand zelf opheft of vermijdt. Oftewel wanneer je er niet door in conflict kome met jezelf.

- Wanneer het iemand in staat stelt conflicten met zijn omgeving te vermijden ${ }^{\text {t6 }}$.

Wanneer in de cursus de gedachten die aan de ongewenste emotie ten grondslag liggen zijn opgespoord, gaat men deze toetsen met behulp van bovenstaande rationaliteitscriteria. Om een gedachte rationeel, ofwel onschadelijk voor het welbevinden van verzorgers te laten zijn, dienen ze bijvoorbeeld aan drie van de vier criteria te voldoen. Gestolde, irrationele gedachten dienen omgebogen te worden 
in rationele en vervolgens dienen de rationele gedachten eigen gemaakt te worden. Zo zou het idee dat een verzorger 'moet zorgen' irrationeel zijn en aldus her geven van zorg bemoeilijken. Indien de verzorger leert denken in termen van 'mogen zorgen' komt dat de zorg ten goede. Dir vraagt veel oefening en herhaling. Maar de veronderstelling is dat gedachten emoties constitueren en als dat idee klopt is er geen andere manier om deze emoties te veranderen. Zo'n cursus kan een hulpmiddel zijn. Beleidsmakers spreken verzorgers daarbij aan als 'burger' en 'patiënt'.

E'n laatste vorm van psychologische steun geven beleidsmakers bijvoorbeeld via informatie vastgelegd in folders. Als voorbeeld een folder, uitgebracht met het doel verzorgers tips te geven zodat ze de zorg voor een ander mer de zorg voor henzelf kunnen combineren ${ }^{17}$. De samenstellers van deze folder stellen hierin de volgende acht leefregels voor:

I. houd je eigen gezondheid in de gaten.

2. blijf goed eten.

3. rust goed uit.

4. blijf fit.

5. stop je gevoel niet weg.

6. stel je grenzen.

7. voorkom stress en

8. kom op voor jezelf ${ }^{18}$.

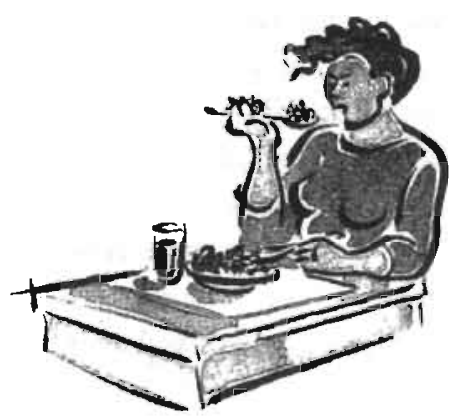

Figuur 4: Overdruk uit folder van het LOT ter ondersteuning van verzorgers.

Hoewel deze folder het besef articuleert verzorgers serieus te nemen worden ze (impliciet) gevraagd zorg voor een ander op zich te nemen, maar daarbij moeten ze goed op hun eigen welzijn letten. Verzorgers worden ook nu aangesproken als 'burger', maar vooral als potentiële 'patiënt'.

Hoewel het dus lijkt dat beleidsmakers met hun ondersteunende maatregelen voor verzorgers aansluiten bij noden en wensen van verzorgers, is dat niet helemaal het geval. Beleidsmakers hanteren immers, zelfs bij die ondersteunende maatregelen, een andere definitie van informele zorg dan verzorgers. Zij formuleren de maatregelen in een 'politiek/sociaal' en 'psychologisch' taal en schuiven daarmee her 'romantisch' taalgebruik over zorg naar de achtergrond. Met andere woorden: Er zit een wezenlijk verschil tussen de betekenis die beleidsmakers aan 
informele zorg geven en de betekenis die verzorgers er zelf aan geven. Dat is zelfs in de ondersteunende maatregelen te constateren. Hoe is dat te zien?

Op de eerste plaats individualiseert het beleid met het uitvaardigen van ondersteunende maatregelen de informele zorg. Beleidsmakers stellen alleen de verzorgster verantwoordelijk voor de (kwaliteit van) zorg en het succes of falen hiervan. De verzorgster onrvangt geld voor geleverde diensten, zij moet cursussen volgen en is diegene die leefregels in acht moet nemen. Terwijl verzorgers in hun vertoog sociale relaries als het meest wezenlijke onderdeel van zorg beschrijven en daarmee interactie, wederkerigheid en athankelijkheid tussen betrokkenen hoog in het vaandel hebben, komt dat in deze intervencies nauwelijks terug.

Ten tweede geven deze maatregelen een beperkte definitie van zorg. Zo staat bij de betaling, zorg als economische dienst op de voorgrond. De zorgtaak is nog enkel een kwestie van tijd en geld. Tijdens de Rer cursussen wordt zorg getransformeerd tot een cognitieve activiteit; een methode, een rechniek. En in de folder wordt informele zorg gepsychologiseerd; goede informele zorg staat of valt met het lichamelijke en psychische welzijn van verzorgers. Terwijl verzorgers wijzen op de complexiteit van informele zorg waarin bijvoorbeeld lichamelijke, psychologische en sociale factoren samengaan en deze zorg vorm krijgt in een netwerk van afhankelijkheidsrelaties, wordt informele zorg in de afzonderlijke interventies tot slechts één dimensie gereduceerd.

Tot slot is bij al deze maatregelen 'de professional' de norm. Zo krijgr de informele verzorgster evenals professionals betaald, krijgt ze via de cursus meer kennis (over distantie) en moet ze volgens de folder zorgen voor een goed 'werkklimaat'. Beleidsmakers interveniëren dus op zo'n manier dar verzorgsters gedrag moeten (gaan) vertonen dat men normaliter aan professionals toedicht. In dit licht zijn ook de in hoofdstuk 2 genoemde maatregelen te zien. Het instellen van respijtzorg wil bijwoorbeeld zeggen dar informele verzorgers zich naar professionele normen moeten schikken. Ze verlenen geen 24-uur zorg meer, maar evenals de professionals, intermitterend. Ook mondelinge of schriftelijke informatic over de ziekte, al of niet in de vorm van een cursus moeten ertoe leiden dat informele verzorgers niet langer intuïtief of proefondervindelijk handelen, maar evenals de professionals op basis van door scholing opgedane kennis. Bij her voorstel tot zorgverlof tor slor kan de informele verzorger afstand nemen, energie opladen om zich daarna volledig te richren op de te bieden zorg. Zorg geven wordt op die manier 'een baan'. Kortom: de voorgestelde ondersteunende matregelen verkleinen als het ware de in het informele-zorgbeleid geconstrueerde hiërarchische relatie tussen het werk van professionals en leken. Dat wat beleidsmakers als kenmerkend voor professionals beschouwen zoals onderbroken contact, betaling, kennis, rationaliteit en beschikbaarheid reiken ze ook informele verzorgers aan. Anders: wie beleidson- 
dersteunende maatregelen voor informele verzorgers nader beschouwt ziet dat beleidsmakers informele zorgarbeid 'professionaliseren'.

In deze opvatting van professionele zorg staat de 'rationele kant' van zorg op de voorgrond en is voor de 'relationele' component minder ruimte ${ }^{19}$. Het beleid beschouwt zorgprofessionals als autonoom handelende personen die geabstraheerde kennis over een specifiek domein bezitten en daarmee volgens de in een beroepsgroep erkende systematiek kunnen handelen. Professionals oefenen volgens beleidsmakers een beroep uit gebaseerd op een specialistische studie met als doel hulp te verlenen of adviezen te verstrekken aan derden tegen bepaald honorarium of salaris ${ }^{20}$. Aan dit beeld spiegelen ze verzorgers. Ze nemen dit over wanneer ze oplossingen voor informele verzorgers aandragen. En dat terwijl verzorgers stellen dat zorg voor terminale patiënten, zich niet zozeer zou moeten richten op autonoom handelen, technische competentie en methodiek, maar eerst en vooral door een houding die blijk geeft van betrokkenheid en empathie. Anders gezegd: terwijl verzorgers informele zorg definiëren als een voortdurende afstemming tussen kennis en houding, tussen technische vaardigheden en betrokkenheid, schuiven beleidsmakers dit sociale aspect van de informele zorg als emotie, ervaring en nabijheid zelfs bij mensen die gaan sterven als minder-waardig en inferieur naar de achtergrond ${ }^{21}$.

Een (succesvol) verzorgster aldus het beleid is sterk. Dit betekent dat ze past binnen het totale systeem, planmatig werkt, rationele, betaalde en afstandelijke zorg verleent. Zo transformeert informele zorg langzaam van een menselijk, emotioneel proces in een handelsartikel; verzorgers van dierbare naasten in werknemers ${ }^{22}$.

Het is de vraag of deze poging informele zorg te rationaliseren betreurenswaardig is. Zo gaat de inzet van geld of techniek in onze cultuur veelal gepaard met meer aanzien. In dat geval zou de verzorgster dus aan status kunnen winnen. En het bestaan van allerlei cursussen voor verzorgers impliceert dat het onzichtbare zichtbaar wordt, dat het private naar de publieke sfeer wordt gehaald. Misschien zouden informele verzorgers juist vanwege het aanleren van professionele kennis en technieken een meer gelijkwaardige positie ten opzichte van professionele verzorgers kunnen verwerven. En als dit het geval is zou een zekere herwaardering van informele zorg plaats kunnen vinden. Daardoor zou deze arbeid serieuzer worden genomen. Bovendien kunnen verzorgers toch geholpen zijn als hun 'zwaktes' worden versterkt. Ze kunnen toch geholpen zijn met wat geld, een cursus of tips om de zorgtaak re volbrengen? Dat is moeilijk te ontkennen.

Wat men echter makkelijk vergeet, is dat bij dergelijke maatregelen beleidsmakers een collectief probleem (namelijk de verdeling van geldelijke middelen voor het zorgsysteem) afwentelen op individuele schouders. Het 'professionaliseren' van informele zorg presenteert het beleid als oplossing voor moeilijkheden rijdens 
de zorgarbeid, maar een andere verdeling van geldelijke middelen nemen beleidsmakers niet meer in beschouwing. Waarom subsidieert de overheid wel cursussen voor verzorgers, maar is er amper geld voor uitbreiding van professionele extramurale zorg of intramurale voorzieningen? Dat neemt natuurlijk niet weg dat veel informele verzorgers blij zullen zijn met een cursus of welke vorm van steun dan ook. Toch benadrukt een dergelijke benadering louter tekortkomingen van individuele verzorgers en stelt geen vragen meer over de inzet en het doel van het informele zorgbeleid zelf.

Behalve dar het extramuralisatie-beleid moeilijk ter discussie kan worden gesteld, impliceren de maatregelen ook dat de wens van de 'patiënt' boven die van de verzorger staat. Terwijl verzorgers soms aangeven de zorg niet meer te kunnen dragen en opname een uitkomst kan bieden, geeft dic beleid daartoe weinig mogelijkheid. Niet de pariënt wordt uit huis gehaald, maar de verzorgster moet haar gedrag aanpassen. Op die manier staat ze noodgedwongen in dienst van de patiënt. Dit gebeurt letterlijk wanneer de patiënt haar betaalt, meer figuurlijk wanneer zij de cursus volgt om haar zorgtaak voor de zieke te volbrengen en eveneens wanneer de folder een zekere grenzeloosheid van verzorgsters suggereert ten opzichte van de zieke. Met het professionaliseren van informele zorg wordt het idee van de verzorgster als 'verlengde arm van de patiënt' bekrachtigd.

Tot slor bieden beleidsmakers verzorgers methoden en standaarden aan die veelal voorbijgaan aan het contingente, contextuele karakter van zorg. Zo is het bijvoorbeeld niet zozeer de vraag of verzorgsters hun eigen gezondheid in de gaten moeten houden, goed uit moeten rusten of grenzen moeten bewaken, de vraag is hoe dat te doen in een situatie waarin niet alleen zij, maar tal van actoren een rol spelen en die bovendien voortdurend aan verandering onderhevig is. Anders gezegd: 'People's willingness to bestow care is shaped by a variety of determinants, including the nature of their attachment to the work force, the texture of their bonds to the care recipient, and the strength of their adherence to such values as family love and filial responsibility. It is highly unlikely that most family members will respond in mechanistic ways to the inducements this group of policy analists would offer them ${ }^{25}$.' In dit verband schrijft een verzorger die een partner met chronische pijn heeft, welke onnatuurlijke inspanningen de cursusleider van hem verlangde tijdens een cursus 'omgaan met de pijn van een partner' ${ }^{24}$. Hij had het gevoel de benadering van zijn partner behoorlijk te moeten manipuleren. Dit stond haaks op de relatie die ze hadden en prettig vonden. Want wat als gevraagd wordt pijn van je geliefde enkel te observeren? Wat als gevraagd wordt het tot een bepaalde tijd te negeren? Wat als gevraagd wordt alleen de pijnuitingen te 'counselen'. Dit berekende gedrag botst met het 'natuurlijke', vanzelfsprekende karakter waarop een relatie stoelt. Door het unieke en 'tragische' karakter van 
informele zorg en de context waarin dit zich afspeelt te negeren, sluit het beleid de contingente handelingspraktijk van de informele verzorger berustend op sociale relaties en daarmee verbonden emotionaliteit en betrokkenheid langzaam uit.

\section{Controle op de eigen verantwoordelijkheid}

In de vorige paragrafen heb ik aangegeven hoe specifiek het ingrijpen van de overheid op informele zorg is. Recente bemoeienis van de overheid betekent niet alleen dat de overheid informele zorgactiviteit aanmoedigt, maar ze definieert ook wat goede zorg is en hoe een informele verzorger zich behoort op te stellen om een succesvol verzorger te zijn. In deze paragraaf plaats ik deze ontwikkeling in een bredere intertekst en maak hierbij gebruik van noties ontleend aan her debat over 'de managementstaat'. Enerzijds wil ik hiermee ronen dat de invloed van 'het managementisme' verder reikt dan professionele organisaries, anderzijds kan ik hiermee de betekenis van de beleidsconventies voor verzorgers scherper verwoorden.

Onze staatsvorm, zo stellen sommige sociale wetenschappers, verandert van een 'verzorgingsstaat' naar een 'managementstaat' ${ }^{25}$. Deze staat heeft twee kenmerken. Op de eerste plaats is het economisch denken en daarbij behorende vocabulaire dominant. Was er tor de jaren negentig sprake van een 'verzorgingsstaat' waarin bijvoorbeeld de onderlinge solidariteit en sociale zekerheid een groot goed waren, vanaf die tijd maakt deze plaats voor de zogenoemde 'managementstaat' waarin de bevordering van efficiëntie en effectiviteit voorop staat. Wat is de invloed van het economisch denken op de status, rol en mogelijkheden van burgers in deze staat? Sociale wetenschappers in Engeland en Nederland debarteren hierover. Ze stellen bijvoorbeeld ook de vrang wat het voor professionals en hun 'cliënten' betekent nu analoog aan her bedrijfsleven het management van zogenoemde non-profit organisaties steeds meer nadruk legt op economisch gedefinieerde efficiëntie en sturing op resultaten ${ }^{26}$. Voorstanders van dit type management wijzen erop dat de doelmatigheid in non-profit instellingen te wensen overlaat. Bovendien is het rechtvaardig dat professionals aan banden worden gelegd, want 'hobbyisme' in een tijd van economische schaarste kan niet worden toegestaan. Sturing op resultaten noopt bovendien tot samenwerking en een geaamenlijke prioriteitenstelling en op die manier zou de continuïteit van dergelijke organisaties gewaarborgd blijven ${ }^{27}$. De critici vinden echter dat de geleidelijke verandering van verzorgingsstaar naar managementstaat een aantal consequenties heeft die juist bij het uitoefenen van beroepen waarbij sociale relaties centraal staan, zoals in de zorgsector, riskant zijn ${ }^{28}$. Zij vinden dat processen zoals in het welzijnswerk, het onderwijs of 
de gezondheidszorg zich nier (alleen) laten uitdrukken in tijd (en geld) omdat dit de kwaliteit van geleverde diensten in gevaar brengt.

Naast sturing van processen op efficiëntie, doelmatigheid en resultaten kenmerkt de managementstaat zich op de tweede plaats doordat ze burgers aanspreekt op (eigen) 'verantwoordelijkheid'. Heel kort gezegd heeft het 'managementisme' als resultaar dat nier alleen managers en bestuurders zeggenschap claimen over geld en produktie(zorg)processen, maar dat ze deze verantwoordelijkheden juist naar andere personen (elders in de staat of organisatie) delegeren. Volgens voorstanders is dit een gunstige ontwikkeling omdat het bijvoorbeeld kostenbewustwording teweeg brengt, bovenal meer gelijkwaardigheid zou brengen; de staats- of organisatiestructuur kan 'platter' zijn. Tegenstanders beweren het regenovergestelde. Decentralisatie gaat volgens hen gepaard met een toenemende controle op het handelen van diegenen die deze verantwoordelijkheden moeten gaan dragen. Ze spreken over 'verstrooiing van macht' ${ }^{29}$.Zo brengt gedelegeerd management bijvoorbeeld niet alleen de mogelijkheid mer zich mee kosten in de gezondheidszorg te controleren en medische zorg tor een zakelijke aangelegenheid te transformeren, maar ook de mogelijkheid patiënten aan te moedigen om in hun eigen zorg te participeren. "The consumer movement conception required a 'patientry' backed bij money. Patient consumers could have power vis-à-vis doctors only if they controlled what economist call demand- the willingness to purchase services backed by resources tot do so. ${ }^{30}$ De patiënt is klant geworden en daarmee medeverantwoordelijk voor de financiële zijde van zijn zorg-, en genezingsproces.

Bezien we vanuit dit perspektief het informele zorgbeleid opnieuw dan is dit ook in termen van het managementisme te duiden. $Z_{0}$ is via de overheid en de professionele zorg ook bij de informele zorg een economisch gerichte taal ingevoerd. De overheid heeft het management van zorgorganisaties opgelegd hun 'core-business' te verantwoorden aan hun financiers, de verzekeraars. Ze moeten meedelen op welk 'product' ze willen worden afgerekend, van welke 'kengetallen' ze gebruik maken en hoe ze de kwaliteit van het produkt willen bewaken en verbeteren. Om dit te doen vragen de managers van thuiszorgorganisaties op hun beurt aan zorgprofessionals om bij te houden welke zorg ze verlenen, aan wie, hoeveel uur ze daaraan besteden en wat het resultaat van de interventie is, liefst aan de hand van cijfermatige prestatienormen. Concreet betekent dit dat sinds de opkomst van de managmentstaat zorgprofessionals zorgresultaten moeten vaststellen, tijd moeten labelen en dus een gedegen administratie moeten bijhouden ${ }^{31}$. Aangezien professionele verzorgers alleen daar mogen komen waar informele verzorgers niet voorhanden zijn, wordt ook aan informeel verzorgenden gevraagd inzicht in hun handelen te geven. Zo vragen indicaticadviseurs aan 
verzorgers bijvoorbeeld te verantwoorden wanneer en hoeveel zorg zij (kunnen) geven. Zorgorganisaties zijn dus niet alleen sterk produktgericht gaan werken, ook her taal-, denk- en gedragsschema van informele verzorgers wijzigt hierdoor. Informele zorg wordt steeds meer in tijd, geld en resultaat uitgedrukt ${ }^{32}$.

Ook het rweede kenmerk van de managementstaat is in het informele-zorgbeleid te zien. Zo hebben beleidsmakers het informele-zorgbeleid aangekondigd als vorm van decentralisatie. Ze schrijven dat met de stimulering van informele zorg de zorg weer in handen van burgers komt te liggen en dichter naar de mensen wordt gebracht ${ }^{33}$. Daarmee doen ze een beroep op de 'eigen verantwoordelijkheid' van verzorgers. Het behoud van een gezondheidszorgsysteem is zelfs voor een deel naar hen gedelegeerd.

De 'burgelijke verantwoordelijkheid' voor het geven van zorg is dus diep in de zorgsector doorgedrongen. Dit gaat echter gepaard met een toenemende controle op het werk van verzorgers. Zo is er een norm geïntroduceerd die verschil aangeeft tussen informele zorg als 'normale zorg' en professionele zorg als 'extra zorg'. Verzorgers moeten dus aantonen dat zij extra zorg geven, willen ze voor professionele zorg in aanmerking komen. Ook de hoeveelheid zorg wordt genoteerd en vastgelegd. Tijdens de indicatiestelling bijvoorbeeld legt de indicatieadviseur een quasi contractuele werkrelatie vast en is in ieder geval afgesproken welke zorg (soms hoeveel) de informele verzorger gaat geven. Tot slot is er toezicht op de kwaliteit van de informele zorg; beleidsmakers en professionals vertellen onbedoeld hoe verzorgers het beste kunnen zorgen. Dat wil zeggen dat verzorgers voldoende afstand moeten nemen, hun zorg funderen in kennis en dat zij zich niet te zeer laten leiden door emoties. De informele sector beweegt zich zelfs richting 'betaalde' arbeid, gepaard gaande met een toenemende investering in trainingen en cerrificeringen voor informele verzorgers. Deze trainingen, folders of cursussen leggen typische 'rationele' zorg-normen aan informele verzorgers op. Daarmee krijgen verzorgers niet meer vrijheid zoals de termen 'decentralisatie" en 'eigen verantwoordelijkheid' wellicht suggereren, maar wordt hun gedrag door beleidsmakers en professionals steeds meer voorgeschreven.

De nadruk op efficiëntie en verantwoordelijkheid verandert de verhouding tussen de publieke en private sfeer. In vergelijking met twintig jaar geleden is de overheid, bij monde van de thuiszorgorganisaties, folders en gesubsidieerde cursussen voor verzorgers meer en meer de privésfeer binnen gedrongen. Ze heeft hiermee zicht, zeggenschap en in zekere zin controle over de hoeveelheid verleende zorg. Zo is het in een praktijk van indicatiestellers gangbaar dat alle thuiswonende kinderen (jongens en meisjes) onder de 18 jaar een verplichte bijdrage leveren aan zorgactiviteiten thuis. Ongeacht of dit past bij de opvoedingsstijl van de ouders of de psychische gesteldheid van het kind. Maar niet alleen is er meer gestan- 
daardiseerde publieke bemoeienis met zorg in de privésfeer. Sinds de overheid indirect, bij monde van indicatieadviseurs anzet tor zoveel mogelijk informele zorg, moeten verzorgers aangeven hoeveel zorg ze geven. Ze worden gedwongen daarover in gesprek te gaan. Cijfers over de hoeveelheid zorg die zij leveren circuleren, hun zwaktes staan in dossiers en zij zijn onderwerp van teambesprekingen bij professionele verzorgers. Zo komen particuliere overwegingen van verzorgers en datgene dat ze tot voor kort als intiem beschouwden, nu in de openbaarheid. Er is dus sprake van een tegengestelde beweging. Enerzijds wordt de verantwoordelijkheid voor zorg meer gedelegeerd. Mensen dienen zelf voor hun naasten te zorgen. De overheid trekt zich terug uit private domeinen. Deze betekenis van privatiseren is een deel van een grotere politieke agenda, die als bedoeling heeft dat middelen (door kostenbeheersing en beleid), keuzes (benadrukken van de burger als klant) en plichten (nadruk op eigen-verantwoordelijkheden) van de staat richting het private domein, de familie of verzorgers te verschuiven. Anderzijds gaat deze verschuiving van verantwoordelijkheden naar verzorgers vergezeld met de onderwerping van diezelfde verzorgers aan grotere controle, regulatie en interventies. Er is dus sprake van disciplinering van verzorgers richting 'rationele werknemers'.

De hervorming van het publieke en private domein is een complex en ingewikkeld proces. Terwijl de staat zich op sommige terreinen terugtrekt, zijn haar taal, conventies en ideeën overgenomen door anderen. Deze zijn verspreid over verschillende partijen en hun instrumenten. Het is daardoor minder doorzichtig wie dirigeert. De staat verlegt dus haar verantwoordelijkheden naar informele verzorgers en creëert tegelijk de mogelijkheid om de informele verzorger te controleren om er zeker van te zijn dat zij hun verantwoordelijkheden dragen. De druk op informele verzorgers neemt ondanks terugtrekking van de overheid toe.

Doordat de overheidsdefinities van (goede) zorg verspreid zijn over verschillende dragers van de macht, wordt informele zorg zelfs voor mensen die gaan sterven steeds minder een kwestie van gevoel en ervaring, van angst, voldoening of van onvoorspelbare relaties tussen mensen. Informele zorg bij her levenseinde is steeds vaker cen kwestie van methode en techniek; cen te leren activiteit waar alleen het resultaat nog telt. Met de opkomst van het managementisme in de informele zorg is de beleidsaanname niet langer dat verzorgers de kwaliteit van zorg voor patiënten verhogen, maar dat ze onvoldoende professionele zorgkwaliteiten hebben of maar moeizaam in staat zijn hun bijdrage (conform de afspraak) te leveren.

Juist omdat her beleid informele verzorgers de laatste jaren nier meer als 'andere' zorgvorm definieert, maar vergelijkt met wat 'eerstelijns-zorg of professionele' zorg is, verschijnen ze als 'minder': minder betaald, minder slim, minder afstandelijk. 
Daardoor zouden ze minder in staat zijn zorg te verlenen. Op dit 'minder zijn' is gereageerd met allerlei meestal 'rationele' vormen van ondersteuning, educatie en begeleiding van informele verzorgers. Want, zo stellen beleidsmakers, patiënten hebben recht op zorg en informele verzorgers hebben recht op ondersteuning bij het verlenen van zorgarbeid. Het duiden van informele zorg in termen van voldoende of onvoldoende uren en in termen van competent of niet, is op te vatten als rationele en resultaat-gerichte zorg. Deze uiting van managementisme biedt voor verzorgers niet veel hoop op betere tijden. Maar het maakt misschien wel duidelijk dat er een probleem is dat zich nier laat oplossen door beheersing van 'de output' van die (informele) zorg. De onderneming om bij inzet van professionele zorg bij voorbaat vast te stellen wat de informele verzorger te bieden heeft, is een vorm van standaardisatie en poging tot beheersing van die zorg. Als er een manier is om verzorgers tegemoet te komen, dan moet die waarschijnlijk niet zozeer gezocht worden in steeds meer gedetailleerde bepaling van in- en output en draagkracht en draaglast van de informele verzorger, maar in een herformulering van zorg en daarmee van het probleem. Niet met de informele verzorgers is iets mis, maar wel met een raal die steeds meer dwingt zorgprocessen, die zich bij stervende mensen thuis afspelen, in productie-termen te verwoorden ${ }^{34}$. 



\section{Noten}

\section{Noot bij voorwoord}

I Cheyne-Srokes ademhaling staat voor een diepe ademhaling met tussenpozen van vrijwel volkomen stilstand.

\section{Noten bij hoofdstuk $\mathrm{I}$}

I Ministerie van Welzijn, Volksgezondheid Cultuur (1983). Nota Eerstelijnszorg. Leidschendam: wvc. p. 32.

2 Wetenschappelijke Raad voor her Regeringsbeleid (1993). De toekomst uan de thuiszorg. 's-Gravenhage: WRRB. p. 24.

3 Groenewegen, P.P., A. Kerkstra \& G.A. Jansen (1993). Wachtlijsten in de thuiszorg. Utrecht: Nivel.

4 Hoff, B.W. van 't (1996). Enquete Thuiszorg. Terp Adviesbureau Utrechr: Eck en Wiel.

5 I]zerman, M. \& C. Scholten (1998). Wachtlijsten in de thuiszorg. Eerste meting van de Quick Scan onder toegelaten thuiszorginstellingen. Leiden: Research voor Beleid.

6 zie: IJzerman, M. \& C. Scholten (1998). Wachtlijsten in de thuiszorg. Eerste meting van de Quick Sian onder toegelaten thuiszorginstellingen. Leiden: Research voor Beleid.

7 Philipsen, H. (1977). Beweging in de relatie tussen vraag en aanbod in de thuiszorg. In: Philipsen, H. (1988). Gezondheidszorg als project en bejegening. Waarden ten aanzien van ziekte, gezondheid en samenleving. Maastricht: Rijksuniversiteit Limburg. p. 180-193.

8 zie: Ariès, Ph. (1990). Met het ong op morgen, westerse opvattingen over de dood van de Middeleeuwen tot heden. Amsterdam: Wetenschappelijke Uitgeverij.

9 Elias, N. (1990). De eenzaambeid van stervenden in onze tijd. Amsterdam: Meulenhoff.

Io zie bijvoorbecld: Akker, P.A.M. van den., M.H.L. van Tits \& N.M. Kok (1994). Leven met de dood. Over terminale patiënten en terminale zorg in Nederland. Houten/ Zaventem: Bohn Stafleu Van Loghum.

II Philipsen, H. (1977). Beweging in de relatie tussen vraag en aanbod in de thuiszorg. In: Philipsen, H. (1988). Gezondheidszorg als project en bejegening. Waarden ten aanzien van zickte, gezondheid en samenleving. Maastricht: Rijksuniversiteit Limburg. P. 180-193.

12. Het Scenariorapport Kanker in Nederland schat dat het aantal nieuwe "kandidaten" voor thuiszorg, zal oplopen van 17.000 in 1985 tot 28.500 in het jaar 2000 . Voor de berekening van het aantal kandidaten voor terminale thuiszorg wordt en laag en een hoog scenario gehanteerd. De schatring loopt van 10.000 in 1985 tot 17.000 in 2000 , respectievelijk van II.500 in 1985 tor 25.000 in 2000 . In 1987 vond 1 op de 
drie sterfgevallen aan kanker plaats in het ziekenhuis. Zie ook: Townsend. J., A.O. Frank, D. Fermont, S. Dyer, O. Karran. A. Walgrove \& M. Piper (1990). Terminal cancer care and parients' preference for place of death: a prospecrive study. $\mathrm{Br} \mathrm{Med}$ J, 415-417.

13 zie bijvoorbeeld: Boer, A.H. de., J.C. Hessing-Wagner, M. Moon \& I.S. Schoemakers-Salkinoja (1994). Informele zorg: een verkenning van huidige en toekomstige ontwikkelingen. Rijswijk: Sociaal en Cultureel Planbureau.

Gorter, K.A. (1988). Zorgen voor gehandicapte gezinsleden. Een landelijk onderzoek naar problemen en bulpverlening binnen buishoudens met lichamelijk gehandicapten. Den Haag: Nederlands Instituut voor Maatschappelijk Werkonderzoek. p. 43.

14 Miltenburg, T. (1990). Intensieve Thuiszorg. Ervaringen uit de proefregiós. Nijmegen: Instituut voor Toegepaste Sociale Wetenschappen.

15 zie ook: Akker, P.A.M. van den., M.H.L. van Tits \& N.M. Kok (1994). Leven met de dood. Over terminale patiënten en terminale zorg in Nederland. Houten/Zaventem: Bohn Srafleu Van Loghum.

16 Er is cen aantal synoniemen voor informele zorg. Men gebruikt ook mantelzorg, primaire verzorgers of centrale verzorgers. In dit proefschrift zal ik voornamelijk spreken over informele zorg of verzorgers.

I7 Vernooy-Dassen, M.J.F.J. (1992). Dementie en ibuiszong: een onderzoek naar determinanten van het competentiegevoel van centrale verzögers en het effect van professionele interventie. Lisse: Swets \& Zeirlinger.

I8 respectievelijk studies van: Duijnstee, M. (1993). De belasting van familieleden van dementerenden. Nijkerk: Intro.

Kuyper, M. B. (I993). Op de achtergrond. Een onderzoek naar de problemen van partners van patiënten met een chronische ziekte. Amsterdam: Thesis Publishers.

Schure, L. M. (1995). Partners van cva patiënten. Een onderzoek naar de gevolgen van een cerebrovasculair accident voor de partner van een patiënt. Groningen: Regenboog.

I9 Twigg, J. \& K. Atkin (1994). Carers Perceived. Policy and Practice in Informal Care. Buckingham-Philadelphia: Open University Press. p. 8.

20 zie bijvoorbeeld: Boer, A.H. de., J.C. Hessing-Wagner, M. Mootz \& I.S. Schoemakers-Salkinoja (1994). Informele zorg: een verkenning van buidige en toekomstige ontwikkelingen. Rijswijk: Sociaal en Cultureel Planbureau.

Mc Cann, J.J. (1988). Long Term Home Care for the Elderly: Perceptions of Nurses, Physicians and Primary Caregivers. QRB, march, 66-74.

21 Hattinga Verschure, J.C.M. (1981). Het verschijnsel zorg: Een inleiding tot de zorgḱkunde. Lochem: De Tijdstroom. p. 55 .

22 Ministerie van Welzijn, Volksgezondheid Cultuur (1983). Nota Eerstelijnszorg. Leidschendam: wrc. p. 81 .

23 zie bijvoorbeeld: Oudhof, P. (1996). De betaalbaarheid van de thuiszorg. Een pleidooi voor herbezinning. In: Dokrer, H., P. van Lieshour \& B. Schade (1996). Zorg aan buis. Een stand van zaken. Utrecht: De Tijdstroom. p. 129-141.

24 zie: Ministeric van Welzijn, Volksgezondheid en Cultuur/Heroverwegingsgroep (I990). Van samenwerken naar samengaan: gezinszorg en krwiswerk naar een geïntegreerd aanbod in de thuiszong. Rijswijk: wvc. 
25 Ministerie van Volksgezondheid Welzijn en Sport (1995). Stimuleringsprogramma thwiszorgtechnologie projectresultaten 1991-1994. Groningen: krzz/vws. p. 14.

26 Hoe rechnologie zich tor zorg verhoudt is overigens niet eenvoudig te beantwoorden. Zie bijvoorbeeld:

Berg, M. \& S.M. van der Lyke (1997). De normativiteit van een infuuspomp. Over zorgprakrijken en rechnologie. In: M. Verkerk (red) Denken over Zorg. Concepten en praktijken. Utrecht: Elsevier/ de Tijdstroom.

27 Kwaliteits Instituut voor Toegepaste Thuzorgvernieuwing/Ministerie van Volksgezondheid, Welzijn en Sport (1995). Stimuleringsprogramma Thuiszorgtechnologie, projectresultaten 1991-1994. Groningen: KIтzz-Ministerie van vws.

28 uit: Friele, R.D. \& J.J. Kerssens (1995). Techniek in de thuiszorg. Evaluatie van het stimuleringsprogramma thuiszorgtechnologie. Utrecht: Nivel.

29 zie ook: Lyke, S.M. van der, P.H. Toren (1996). Een kwestie van vertrouwen. Procesevaluatie van indicariesystemen in de thuiszorg. Verpleegkunde, 23-30.

30 Groenewegen, P.P., A. Kerkstra \& G.A. Jansen (1993). Wachtlijsten in de thuiszorg. Utrecht: Nivel. p. 9.

31 zie ook: Potring, M. (1997). Van je familie. Tijdschrift voor Gezondheid en Politiek, 2, 23-24.

32 Visser $(1996,169)$ beschrijft GIRST als een samenhangend informatie- en registratiesysteem voor de thuiszorg. Het is ontwikkeld door het Nederlands Instituut voor Zorg en Welzijn en gebouwd en gedistribueerd door GINo bv. in Groningen. Met gIrST kan op geautomariseerde wijze informatie uit het zorgproces worden vastgelegd. Het is opgebouwd uit vier modules, die de fasen van het zorgproces beslaan. De informatie die door GIRST wordt vastgelegd heeft volgens Visser een drieledige functic. Het dient ter ondersteuning van het zorgproces, her is van belang voor her beleid en beheer van thuiszorgorganisaries en het is bedoeld om informatie voor zorgverzekeraars te verzamelen. De nadruk bij dit systeem zou liggen op de ondersteuning van de directe zorg voor cliënten. GIRST zou zowel geschikt zijn voor eenvoudige als complexe zorgsituaries waarbij meerdere hulpverleners betrokken zijn en is een methode (+instrument) om vanuit verschillende disciplines in dezelfde taal mer elkaar te communiceren over een zorgsituaric.

33 zie ook: Kempen, G.I.J.M. (1990). Thuiszorg voor ouderen. Groningen: siyx Publications.

34. Vanaf $\mathrm{I}$ januari 1998 is de indicatiestelling in de sector verzorging en verpleging gebaseerd op het Zorgindicatiebesluit. Daarmee zijn de eerder afzonderlijke indicatiestellingen voor de thuiszorg, verzorgings-, en verpleeghuizen in één regie gebracht. De regie ligt in handen van zogenoemde Ro's. Dit staat voor Regionale Instelling Indicatie Organen. $\mathrm{Zij}$ worden ingesteld door gemeentebesturen met vertegenwoordigers van patiënten/consumentenorganisaties, zorgaanbieders, huisartsen, verzekeraars en gemeenten: op basis yan intergemeentelijke samenwerking zijn dit ruim 80 RIo's. Dit betekent dat men op dit moment bezig is met her opzetren van werkorganisaties om de indicatiestelling uit te voeren, het onderbrengen van ca. 230 indicatiecommissies voor verzorgings- en verpleeghuizen in ruim 80 rio's met de daarbij behorende overheveling van personeel, overheveling indicatiestelling thuiszorg van thuiszorginstellingen naar RIo's, uitnemen van 62,5 miljoen apparaatkosten uit AWBz middelen voor 
thuiszorginstelingen, toevoeging 72,5 miljoen aan Gemeentefonds voor indicatiestelling door Ro's.

35 Tegelijk met een veranderende en toegenomen zorgvraag vermindert het aanbod van intramurale bedden door de ingang zijnde beddenreductie voor ziekenhuizen en de achterblijvende capaciteitsruimte van verpleeg- en verzorginghuizen.

36 zie: Bos, G.A.M. van den (1989). Zorgen van en voor chronisch zieken. Utrecht: Bohn, Schelrema en Holkema.

Philipsen, H. (1985). Rationaliteit en ons oordeel over de verdwijnende pariënt. Gezondheid en Samenleving, 142-152.

37 zie bijvoorbeeld: Minisrerie van Welzijn, Volksgezondheid en Cultuur. Interdepartementale werkgroep vergrijzingsproblemariek wvc (1986). Kosten van vergrijzing voor wvc. Leidschendam: wvc.

Ministerie van Welzijn, Volksgezondheid en Cultuur (1986). Nota Zorg voor Ouderen. Leidschendam: wrc.

38 Ministeric van Volksgezondheid Welzijn en Sport (1997). Thuiszorg en zorg thuis, kansen voor de toekomst. Rijswijk: vws. p. 6.

39 zie: Ministerie van Welzijn Volksgezondheid Cultuur (1983). Nota Volksgezondheid bij beperkte middelen. Leidschendam: wvc. Deze nota introduceert thuiszorg als middel om de zelfstandigheid van de patiënt zo lang mogelijk in stand te houden.

40 Nationale Raad voor de Volksgezondheid (1985). Advies kwaliteit, onganisatie en financiering thuiszorg. Zoetermeer: NRV. p. 22.

4 Ministerie van Volksgezondheid Welzijn en Sport (1997). Thuiszorg en zorg thuis, kansen voor de toekomst. Rijswijk: vws. p. 6.

42 Ministerie van Volksgezondheid Welzijn en Sport (1997). Thuiszorg en zorg thuis, kansen voor de toekomst. Rijswijk: vws. p. 6.

43 zie: Nationale Raad voor de Volksgezondheid (1985). Advies kwaliteit, organisatic en financiering thuiszorg. Zoetermeer: NRv. p. 20.

Ministerie van Volksgezondheid Welzijn en Sport (1997). Thuiszorg en zorg thuis, kansen voor de toekomst. Rijswijk: vws. p. 19.

44 Nationale Raad voor de Volksgezondheid (1985). Advies kwaliteit, organisatie en financiering thuiszorg. Zoetermeer: NRv. p. 20.

45 Wetenschappelijke Raad voor her Regeringsbeleid (1993). De toekomst van de thuiszorg. 's-Gravenhage: wrRB. p. 39.

46 Ministerie van Welzijn, Volksgezondheid Cultuur (1983). Nota Eerstelijnszorg. Leidschendam: wrc. p. 6.

47 Ministerie van Welzijn Volksgezondheid Cultuur (1992). Dat luistert nanw. Samenvatting van de notitie Thuiszorg in de jaren negentig. Rijswijk: wvc. p. 25.

48 Nationale Raad voor de Volksgezondheid (1989). Discussienota Thuiszarg. Zoetermecr: NRV. p. 20.

49 Ministerie van Volksgezondheid Welzijn en Sport (1997). Thuiszong en zorg thuis, kansen voor de toekomst. Kijswijk: vws. p. 6.

Wetenschappelijke Raad voor het Regeringsbeleid (1993). De toekomst van de thuiszorg. 's-Gravenhage: WRRB. p. 10.

so Nationale Raad voor de Volksgezondheid (1989). Discussienota Thuiszorg. Zoetermeer: NRV. P. 8. 
Bos, G.A.M. van den (1989). Zorgen van en voor chronisch zieken. Utrecht: Bohn, Scheltema en Holkema. p. 124.

sI Londen, 3. van (1987). Thuiszorg, Huiswerk voor allen wóór het jaar 2000. Utrecht: Rijksuniversiteit Utrecht. (oratie)

$\$ 2$ zie bijvoorbeeld ook: Abma. T.A. (1996). Responsief evalueren. Discoursen controversen en allianties in bet postmoderne. Delf: Eburon.

Kensen, S. (r999). Sturen up variatie. Sociale Vernieuwing en de deense variant als bronnen van inspinatie. 's-Gravenhage: $\mathrm{VNG}$ Uitgeverij.

Roe, E. (1994). Narrative Policy Analysis. Durhum London: Duke University Press.

5. zie ook: Meyer, M. (1996). In tekst gevat. Inleiding tot een kritiek van representatie. Amsterdam: University Press.

54 zie: Twist, M. van (1994). Verbale Vernienwing. Aantekeningen oner de kunst van bestuurskunde. 's-Gravenhage: vUGA.

55 zie ook: Roe, E. (1994). Narrative Policy Analysis. Durhum London: Duke University Press.

Wagenaar, H. (1995). "Urgent stories; morality and narrative in public administration." Adminstration theory of praxis, 92-104.

56 Verbiest $(1999,8)$ beschrijft her 'androcentrisch perspectief' als een perspectief op de maatschappii dat zelf niet ter discussie staat en dat samenvalt met de positie die mannen in die maatschappij innemen.

57 zie ook: Abma, T.A. (1996). Responsief ewalueren. Discoursen controversen en allianties in het postmoderne. Delft: Eburon. p. 6I-87.

Ploeg, I. van der (1991). Verdwenen lichamen. Voortplantingstechnieken, vrouwenlichamen en vaders in beleidsrapporten over in vitro fertilisatie en kunstmatige inseminatie. Tijdschrift voor Vrouwenstudies, 329-347.

58 Maarse, J.A.M. (1990). Beleidsanalyse in de gezondheidszorg. In: Maarse, J.A.M. \& I.M. Mur-Veeman (red) Beleid en beheer in de gezondheidszorg. Problemen, structuren, processen en effecten. Assen/Maastricht: Van Gorcum. p. I88.

59 zie ook: Eeten, M.J.G. van, M.J.W van Twist \& P.R. Kaanders (1996). Verhalen vertellen. Van een narratieve bestuurskunde naar een posmoderne beweerkunde? Bestuurskunde, 168-185.

Graaf, H. van de. \& R. Hoppe (1996). De interpretarie wan een beleidscekst. In: Beleid en Politiek. Een inleiding tot de beleidswetenschap en de beleidskunde. Bussum: Courinho.

Hoppe, R. (1993). Polirical Judgment and Policy Cycle: The Case of Enniciry Policy Arguments in the Netherlands. In: Fischer, F. \& J. Forester (eds) The argumentative turn in Policy Analysis and Planning. London: vC.. Press.

60 Zoals gebruikelijk in kwalitatief onderzoek lopen de fasen van dataverzameling en analyse door elkaar heen. De dataverzameling en analyse zijn vooral gestuurd door het theoretisch kader van dit onderzoek.

6I Maarse, J.A.M. (1990). Beleidsanalyse in de gezondheidszorg. In: Maarse, J.A.M. \& I.M. Mur-Veeman (red) Beleid en beheer in de gezondheidszarg. Problemen, structuren, processen en effecten. Assen/Maastricht: Van Gorcum. p. 188.

62 Twist, M. van (1994). Verbale Verniewwing. Aantekeningen over de kunst van bestuurskunde. 's-Gravenhage: vUGA. p. 103. 
63 Het concept 'vertoog of discours' wordt door Keulartz $(1987,13)$ gedefinieerd als een verzarneling uitspraken die een geordend geheel of systeem vormt. Meyer $(1996,27)$ noemt een vertoog een wijze van spreken over iets dat tegelijk geïstitutionaliseerd is in wijze van handelen; oftewel een 'groepstaal' in ruime zin.

64 zie ook: Meyer, M. (1996). In tekst gevat. Inleiding tot een kritiek van representatie. Amsterdam: University Press. p. 18-35.

Twist, M. van (1994). Verbale Vernieuwing. Aantekeningen over de kunst van bestuurskunde. 's-Gravenhage: vuGa. p. 103-108.

Roe, E. (1994). Narrative Policy Analysis. Durhum London: Duke University Press. p. $1-7$.

65 Deze indeling en voorbeelden zijn overgenomen uit: Meyer, M. (1996). In tekst gevat. Inleiding tot een kritiek van representatie. Amsterdam: University Press. p. 25-27.

66 Definities uit: Meyer, M. (1996). In tekst gevat. Inleiding tot een kritiek van representatie. Amsterdam: University Press. p. 33.

67 Meyer, M. (1996). In tekst gevat. Inleiding tot een kritiek van representatie. Amsterdam: Universiry Press. p. 33.

68 zie bijvoorbeeld: Hagemann-White, C. (1989). Geslacht en Gedrag. In: Sevenhuijsen, S. (red) Socialistische-Feministische Teksten. Baarn: Ambo.

Scott, J. (1986). 'Gender: A Useful Category of Historical Analysis.' American Historical Review, 1053-1075.

69 zie ook: Oudshoorn, N.E.J. (1996). Genderscripts in technologie. Noodlot of uitdaging. Enschede: Universiteir Twente. (oratie)

70 uir: Verbiest, A. (1999). Zaken zijn zaken. Taal en kwaliteit van beleid. 's-Gravenhage: Ministerie van Sociale zaken en Werkgelegenheid. p. 7.

7I zie bijvoorbeeld: Bruijn, J. de (1991). Functiewaardering en beloning van vrouwenwerk. Tijdschrift voor Vrouwenstudies, 19-31.

Halsema, L. (1994). Een gender-subrekst van beleid. Een analyse van 'Een werkend perspektief' van de Wetenschappelijke Raad voor het Regeringsbeleid. Tijdschrift voor Vrouwenstudies, 212-224.

72 uit: Halsema, L. (1994). Een gender-subtekst van beleid. Een analyse van 'Een werkend perspektief van de Wetenschappelijke Raad voor het Regeringsbeleid. Tijdschrift voor Vroumenstudies, p. 212.

73 Vergelijk hier het concept 'gender-script' dat in technologie-onderzoek gebruikt wordt om aan te geven dat in ieder technologisch artefact expliciete en impliciete keuzen ren grondslag liggen die gebaseerd zijn op veronderstellingen over mannelijkheid en vrouwelijkheid in het beoogde gebruik.

74 citaat uit: Meyer, M. (1996). In tekst gevat. Inleiding tot een kritick van representatie. Amsterdam: University Press. p. 2.

75 zie: Verbiest, A. (1999). Zaken zijn zaken. Taal en kwaliteit van beleid. 's-Gravenhage: Ministerie van Sociale zaken en Werkgelegenheid.

76 zie: Benschop, Y. (1996). De mantel der gelijkheid. Gender in organisaties. Assen: Van Gorcum.

77 zie: Bruijn, J.G.M. de (1991). Omstreden kwaliteit: omtrent vrowwenarbeid en beleid. Amsterdam: vo University Press. (oratie) 
Bruäjn, ). de (rg9r). Functiewaardering en beloning van vrouwenwerk. Tijdschrift voor Wrosumenstudies, $19-3$.

7. Daal H.), vaa (r9go). Vrijwilligerswerk en informele hulp in Nederland. Een inventarisatic wan onbetadld werk buiten het eigen huibhouden, in het bijzonder op het gebied van de hulpverlening "S-Gravenhage: Nederlands lnstituut voor Maatschappelijk. Werk Onderzock. p. 129.

7. In Nederland wordt het gros wan de informele zorg door vrouwen werleend. Als er sprake is wan ziekre of handicap bieden tweemal zoved wrouwen dan mannen informele zorg. In eerste instantie wondt bij ziekte een beroep gedaan op de partner. Deze wordt veelal beschouwd als "generalist", Ool worden andere leden van her sirecte sociale newwerk, zoals kinderen, buren, wriender verantwoordelijkheden toebededd. Zij worden als" specialisten' gerien, zie ook:

Goer, A.H. de., J.C. Hessing-Wagner, M. Mootz \&. I. S. Schoemakers-Salkinoja (r994). Informele ang: en werkenning wan buidige en tockonstige ontwikkelingen. Rijswijk: Sociaal en Cultureel Mlanbureas. p. rzo-i49.

Tadens, F.L.]. \& CI. Woldringh (rg89). Informele song in Nederland: zelfzorgproblewen, behoefie aun zong en prathisch-instrumentele onderlinge holp. Nijmegen: Institumt wor Toegepaste Seciale Werenschappen.

Brody, E.M. (rgst). "Women 埤 the middle" and Family Help so Older People. The Gerontologist, 471-480.

Brody, E.M. (1990). Women in the middle; their parent-care years. New York: Springer.

So Mc Cann, K. \& E. Wadsworth (1992). The role of informal carers in supporting gay men who have HIV related illness: what do they do and what are their needs? Aids Care, $25-34$.

81 zie bijvoorbeeld: Davies, C. (1995). Gender and the professional predicament of nursing. Buckingham/Philiadelphia: Open University Press.

Gremmen, I. (1995). Ethiek in de gezinsverzorging. Gender en de macht van zorg. Utrecht: Jan van Arkel.

Simonen, L. (1990). Contradictions of the Welfare State, Women and Caring. Tampere: University of Tampere.

Vulto, M. \& M. Morée (1996). Thuisverzorging als professie. Een combinatie pan hand, hoofd en hart. Utrecht: De Tijdstroom.

82 zie: Tronto J.C. (1993). Moral Boundaries. A political argument for an ethics of care. New York/London: Routledge. p. 10I-127.

83 zie ook: Tronto J.C. (x993). Moral Boundaries. A political argument for an ethics of care. New York/London: Routledge.

84 zie ook: Brouns, M. \& M. Zwinkels (1995). Arbeid, zorg en autonomie. In: Brouns, M., M. Verloo \& M. Grunell (red) Vrouwenstudies in de jaren negentig. Een kennismaking wanuit verschillende disciplines. Bussum: Coutinho. p. $261-287$.

Waerness, K. (1987). 'On the rationality of caring'. In: A.S. Showstack Sassoon (ed) Women and the state. The shifting boundaries of public and private. London: Hutchinson Education. p. 207-234.

85 zie: Roe, E. (1994). Narrative Policy Analysis. Durhum London: Duke University Press. 
86 Keulartz, J. (1987). Van bestraffing naar behandeling. Een inleiding in de sociologie van de hulpverlening: Amsterdam/Meppel: Boom. p. 93.

87 zie: Peräkylä, A. (1997). Reliability and validity in research based on transcripts. In: Silverman, D. (ed) Qualitative Research. Theory, Method and Practice. London: Sage Publications.

88 De beleidsmaker beperkt zich in dit onderzoek niet tot een individu of tot een groep ambrenaren op een ministerie. De beleidsmaker is een constellatie of configuratie van losjes met elkaar verbonden overheidsorganisaties die ten behoeve van beleid teksten produceren over informele zorg.

89 Voor het woord 'con-tekst' zie: Twist, $M$ van (1994) Verbale Vernietawing, aantekeningen over de kunst van bestuurkunde. 's-Gravenhage. VUGA.

90 Silverman, D. (2000). Validity and reliability. In: D. Silverman. Doing Qualitative Research. Practical Handbook. London: Sage Publication.

91 uit: Twigg, J. \& K. Ackin (1994). Carers Perceived. Policy and Practice in Informal Care. Buckingham-Philadelphia: Open University Press. p. 6.

92 zie ook: Clipp E.C. \& L.K. George (1993). Dementia and Cancer: a comparison of spouse caregivers. The Gerontologist, 534-541.

93 zie: Glaser, B. \& A. Strauss (1965). The Awareness of Dying. Chicago: Aldine.

94 zie bijvoorbeeld: Akker, P.A.M. van den., M.H.L. van Tits \& N.M. Kok (1994). Leven met de dood. Over terminale patiënten en terminale zorg in Nederland. Houten/ Zaventem: Bohn Stalleu Van Loghum.

os zie bijvoorbeeld: Daal H.J. van (1990). Vrijwilligerswerk en informele hulp in Nederland. Een inventarisatic van onbetaald werk buiten het eigen huishouden, in het bijzonder op het gebied van de hulpverlening. 's-Gravenhage: Nederlands Instituut voor Maatschappelijk Werk Onderzoek.

Kwekkeboom, M.H. (1990). Het licht onder de Korenmaat. Informele zorgverlening in Nederland. 's-Gravenhage: vuGa.

Lewis, J. \& B. Meredith (1988). Daughters who care: daughters caring for mothers at home. London/New York: Routledge.

96 Van alle 60 aanmeldingen om mee te werken aan het onderzoek heb ik een lijst aangelegd, met daarop gegevens van porentiële interviewkandidaten (zie bijlage 3). Ik heb uit deze lijst a-select een derrigtal verzorgers gevraagd of ik ze mocht interviewen. De andere 30 heb ik een vragenlijst gestuurd. Na 20 van de voorgenomen 30 interviews bleck het verzadigingspunt bereikt. De resterende io potentiële interviewkandidaten heb ik bedankt voor hun interesse en telefonisch verteld dat ik genoeg informatie had.

97. Deze vragen hielden verband met de drie thema's die ik uit de beleidsteksten had geanalyseerd. Bovendien had ik enkele dagdelen observaties gedaan bij informele verzorgers. Ik was bij deze mensen thuis gekomen door mee te gaan met een wijkverpleegkundige (zie impressie). Het belangrijkste doel van deze observaties was er zeker van te zijn dat de interviewvragen aansloten bij de praktijk van de verzorgers.

98 Roe, E. (1994). Narrative Policy Analysis. Durhum London: Duke University Press. p. 3 . 
99 zie ook: Ploeg, I. van der (1991). Verdwenen lichamen. Voortplantingstechnieken, vrouwenlichamen en vaders in beleidsrapporten over in vitro fertilisatie en kunstmatige inseminatic. Tijdschrift voor Vrouwenstudies, 329-347.

Ioo Interessante polemick in het kader van deze studie:

Hoogerwerf. A. (1995). Beleidswetenschap als uirdaging voor vrouwenstudies. Beleidswetenschap, 347-351.

Keuzenkamp, S. \& M. Schaapman (1995). Vrouwenstudies als uitdaging voor beleidswetenschappers. Beleidswetenschap, 342-346.

Ior vergelijk: Oudshoorn, N.E.J. (1996). Genderscripts in technologie. Noodlot of uitdaging. Enschede: Universiteit Twente. (oratie)

\section{Noten bij hoofdstuk 2}

1 Wetenschappelijke Raad voor het Regeringsbeleid (1993). De tockomst van de thuiszorg. 's-Gravenhage: WRRB. p. 39.

2 Nationale Raad voor de Volksgezondheid (1991). Advies ondersteuning mantelzorg. Zoetermeer: NRV. p. 29.

3 zie bijvoorbecld: Tijssen, I.M.J.G. \& E. Elsinga (1990). Evaluatic-onderzoek op het terrein van de gezondheidszorg. In: Maarse, J.A.M. \& I.M. Mur-Veeman (red) Beleid en beheer in de gezondheidszorg. Problemen, structuren, processen en effecten. Assen/ Maastricht: Van Gorcum. p. 215-234.

4 Twigg, J. \& K. Ackin (1994). Carers Perceived. Policy and Practice in Informal Care. Buckingham-Philadelphia: Open University Press.

5 zie ook: Goudriaan, G. (1988). Thuiszorg tussen de lijnen. Den Haag: Harmonisatieraad Welzijnsbeleid.

6 Tweede Kamer (1973-1974). Structuurnota Gezondheidszorg. 's-Gravenhage: Staatsuitgeverij.

7 Ministerie van Welzijn, Volksgezondheid Cultuur (1983). Nota Eerstelijnszorg. Leidschendam: wvc. p. 6-8.

8 Ministerie van Welzijn, Volksgezondheid Cultuur (1983). Nota Eerstelijnszarg. Leidschendam: wvc. p. 3.

9 Ministerie van Welzijn, Volksgezondheid Cultuur (1983). Nota Eerstelijnszorg. Leidschendam: wvc. p. 46.

10 Ministerie van Welzijn, Volksgezondheid Cultuur (1983). Nota Eerstelijnszorg: Leidschendam: wvc. p. 13 .

II Ministerie van Welzijn, Volksgezondheid Cultuur (1983). Nota Eerstelijnszorg. Leidschendam: wvc. p. 6.

12 Werenschappelijke Raad voor her Regeringsbeleid (1993). De toekomst van de thuiszorg. 's-Gravenhage: WRRB. p. 28.

13 Ziekenfondsraad (1985). Advies Terminale Thuiszorg. Arnstelveen: ZFr. p. 13.

14 Ministerie van Welzijn, Volksgezondheid Cultuur (1983). Nota Eerstelijnszorg. Leidschendam: wvc. p. Ir. 
is Ministerie van Welzijn Volksgezondheid Cultuur (1983). Nota Volksgezondheid bij beperkte middelen. Leidschendam: wvc. p. 67.

16 Nationale Raad voor de Volksgezondheid ( 1989 ). Discussienota substitutie in de gezondheidszorg. Zoetermeer: NRV. p. 8.

17 Nationale Raad voor de Volksgezondheid (1985). Advies kwaliteit, organisatic en financiering thuiszorg. Zoetermeer: NRv. p. 30.

18 Ministerie van Welzijn Volksgezondheid Cultuur (1983). Nota Volksgezondheid bij beperkte middelen. Leidschendarn: wrc. p. 67.

19 Ministerie van Welzijn, Volksgezondheid Cultuur (1983). Nota Eerstelijnszorg. Leidschendam: wvc. p. II.

20 zie ook: Boer, A.H. de., J.C. Hessing-Wagner, M. Moorz \& I.S. SchoemakersSalkinoja (1994). Informele zorg: een verkenning van buidige en toekomstige ontwikkelingen. Rijswijk: Sociaal en Culrureel Planbureau. p. 103.

2I zie bijvoorbeeld: Illich, I. (1975). Het medisch bedrijf een bedreiging voor de gezondheid. Baarn: Het Wereldvenster.

22 zie bijvoorbeeld: Illich, I. (1975). Het medisch bedrijf een bedreiging voor de gezondheid. Baarn: Her Wereldvenster.

Zola, I.K. (1973). De medische macht. De invloed van de gezondheidszorg op de maatschappij. Amsterdam: Boom Meppel.

23 zie: Hattinga Verschure, J.C.M. (1972). Ontwikkelingen van zorgcriteria voor herstructurering van de gezondheidszorg. Het Ziekenhuis, 500-505.

Hattinga Verschure, J.C.M. (1979). Mantelzorg. Medisch Contact, 139-142.

Hattinga Verschure, J.C.M. (1987). Zelfredzame ouderen. Lochem/Gent: De Tijdstroom.

Hattinga Verschure, J.C.M. (1989). Mantelzorg rond ouderen. Geriatrie-informatorium, 1020-1-1020-17.

24 zie bijvoorbeeld: Ell Ko., R.H. Nishimoto, J.E. Mantell \& M.B. Hamovitch (1988). Psychological adaption to cancer: a comparison among patients, spouses, and nonspouses. Family Systems Medicin, 335-348.

25 zie ook: Akker, P.A.M. van den., M.H.L. van Tits \& N.M. Kok (1994). Leven met de dood. Over terminale patiënten en terminale zorg in Nederland. Houten/Zaventem: Bohn Stafleu Van Loghum. p. 54 .

26 zie bijvoorbecld: Bloom, J.R. (1982). Social support, accomodation to stress and adjustment tot breast cancer. Social Science or Medicine, 1329-1338.

Bloom, J.R. (1982). Social support systems and cancer; a conceptual view. In: Cohen J., J.W. Cullen \& L.R. Martin (eds) Psychosecial aspects of cancer. New York: Raven Press.

Dunkel-Schetter C., C. Wortman (1982). The interpersonal dynamics of cancer in social relationships and their impacts on patient. In: Friedman H.S., M.R. Dimatteo (eds) Interpersonals lssues in Health Care. New York: Academic Press.

Dunkel-Schetter C. (1984). Social support and cancer: findings based on patient interviews and their implications. Journal Soc. Issues, 77-98.

Lindsey., A.M., J.S. Norbeck V.L. Carrieri \& E. Perry (i981). Social support and Health Care outcomes in postmastectomy women: a review. Cancer Nurs, 377-384. 
Peteet J.R. (r982). A closer view at the concept of support: some applications to the care of patient with cancer. Gen Hosp Pychiatry, 19-23.

Rait D. \& M.S. Lederberg (1989). The family of the cancer parient. In: J.C. Holland, J.H. Rowland (eds) Handbook of psychooncology: psychological care of patient with cancer: New York: Oxford Universicy Press. p. 58-7I.

27 zie bijvoorbeeld: Allbrook, D. (1984). Dying of cancer- home, hospice or hospital. Med. J. Aust, 14I-144.

28 zie bijvoorbeeld: Haes, J.C.J.M. de (1988). Kualiteit van leven van kankerpatiënten. Amsterdam/Lisse: Swets \& Zeitlinger.

Ros, W.J.G. (1990). Sociale steun bij kankerpatiënten. Amsterdam: Thesis Publishers.

29 Ros, W.J.G. (2990). Sociale steun bij kankerpatiënten. Amsterdam: Thesis Publishers.

30 Courtens, A.M. (1993). Kenmerken van zorg en kwaliteit van leven bij patiënten met kankex. Maastricht: UPM.

31 Ziekenfondsraad (1985). Advies Terminale Thuiszorg. Amstelveen: zFr.

32 Ministerie van Welzijn Volksgezondheid Culruur (1992). Dat luistert nauw. Samenvatting van de notitie' Thuiszorg in de jaren negentig. Rijswijk: wvc. p. 19.

33 Ministerie van Welzijn Volksgezondheid Cultuur (1992). Dat histert nawm Samenvatting van de notitie Thuiszorg in de jaren negentig. Rijswijk: wvc. p. II.

34 Wetenschappelijke Raad voor her Regeringsbeleid (1993). De toekomst van de thuiszorg. 's-Gravenhage: wRRB. p. 39.

35 Wetenschappelijke Raad voor het Regeringsbeleid (1993) De toekomst van de thuiszorg. 's-Gravenhage: WRRB. p.4r.

36 Ministerie van Welzijn, Volksgezondheid en Cultuur (1986). Nota Zorg voor Ouderen. Leidschendam: wvc. p. 12.

37 Werenschappelijke Raad voor het Regeringsbeleid (1993). De toekomst van de thuiszorg. 's-Gravenhage: WRRB. p. 42.

38 Wetenschappelijke Raad voor het Regeringsbeleid (1993). De toekomst van de thuiszorg. 's-Gravenhage: WRRB. p. 60.

39 Emancipatieraad (1993). Advies vrouwenmantel in mannetrouw in de thuiszorg. Den Haag: ER. p. 14.

40 Emancipatieraad (1993). Advies vrouwenmantel in mannetrouw in de thuiszorg. Den Haag: ER.

4I Wetenschappelijke Raad voor het Regeringsbeleid (1993). De toekomst van de thuiszorg. 's-Gravenhage: wrRB. p. 39.

42 Wetenschappelijke Raad voor het Regeringsbeleid (1993). De toekomst van de thuiszorg. 's-Gravenhage: wrRB. p. 41.

43 Wetenschappelijke Raad voor het Regeringsbeleid (1993). De toekomst van de thuiszorg. 's-Gravenhage: WRRB. p. 60.

44 Tweede Kamer (1991-1992). Thuiszorg in de jaren negentig. Notitie over de toekomstige ontwikkelingen en stimulering van de Thuiszorg. 's-Gravenhage: Staatsuitgeverij. p. 11.

45 zie bijvoorbeeld: Stuurgroep Toekomst Scenario's Gezondheidszorg (1992). Onderen in het jaar 2005: gezondheid en zorg: geactualiseerde scenario's over gezondheid en vergrijzing rogo-2005. Houten/Zaventem: Bohn, Stafleu van Loghem. 
46 Gezondheidsraad (1991). Advies thuiszorg voor patiënten met kanker:'s Gravenhage: GR. p. 35 .

47 Ministerie van Welzijn, Volksgezondheid en Cultuur (1986). Nota Zorg voor Ouderen. Leidschendam: wrc. p. 12 .

48 Emancipatieraad (1993). Advies vrouwenmantel è mannetroww in de thuiszorg. Den Haag: ER. P. 54 .

49 Tweede Kamer (1991-1992). Thuiszorg in de jaren negentig. Notitie over de toekomstige ontwikkelingen en stimulering van de Thuiszorg. 's-Gravenhage: Staatsuitgeverij. p. II.

so Ministerie van Welzijn Volksgezondheid Cultuur (1992). Dat luistert nauw. Samenvatting van de notitie Thuiszorg in de jaren negentig. Rijswijk: wvc. p. 21.

51 Tweede Kamer (1992-1993). Beleidsprogramma Emancipatie: 'Met het oog op 1995' 's-Gravenhage: Staatsuitgeverij.

52 zie ook: Emancipatieraad (1993). Advies vrouwenmantel in mannetrouw in de thuiszorg. Den Haag: ER. p. 27.

53 zie ook: Brody, E.M. (1981). "Women in the middle" and Family Help ro Older People'. The Gerontologist, $471-480$.

54 zie ook: Brody, E.M. (1981). "Women in the middle" and Family Help to Older People'. The Gerontologist, $471-480$.

Lewis, J. \& B. Meredith (1988). Daughters who care: daughters caring for mothers at bome. London/New York: Roudkdge.

55 zie ook: Horowicz, A. (1485). Family Caregiving to the Frail Elderly. In: Eisdorfer C. (ed) Annual review of gerontology and geriatrics, 194-254.

56 Knipscheer, C.P.M. (1980). Oude mensen en hun sociale omgeving: een studie van het primair sociaal netwerk. 's-Gravenhage: Vuga-boekerij.

57 Kwekkeboom, M.H. (1990). Het licht onder de Korenmaat. Informele zorguerlening in Nederland. 's-Gravenhage: vuGA.

58 Boer, A.H. de., J.C. Hessing-Wagner, M. Moorz \& I.S. Schoemakers-Salkinoja (1994). Informele zorg: een verkenning van buidige en toekomstige ontwikkelingen. Rijswijk: Sociaal en Cultureel Planbureau.

59 Geextrapoleerd naar de gehele bevolking en gewaardeerd met de uurkosten van een gezinsverzorgende. uit: Kwekkeboom, M.H. (1990). Het licht onder de Korenmaat. Informele angverlening in Nederland. 's-Gravenhage: vuGA. p. 54.

6o Knipscheer, C.P.M. (1980). Oude mensen en hun sociale omgeving: een studic van bet primair sociaal netwerk. 's-Gravenhage: Vuga-boekerij.

6r zie bijvoorbeeld: Nugent, L.S. (1988). The social support requirements of family caregivers of terminal cancer patients. The Canadian Journal of Nursing Research, 45-58.

Oberst, M.T., K.A. Gass \& S.E. Ward (1989). Caregiving demands and appraisal of stress among family caregivers. Cancer Nursing, 209-215.

62 Grobe, M.E., D.M. Ilstrup \& D.L. Ahmann (1981). Skills needed bij family members to maintain the care of an advanced cancer patient. Cancer Nursing. $37^{1-375}$.

63 zie bijvoorbeeld: Daal H.J. van (1990). Vrijwilligerswerk en informele hulp in Nederland. Een inventarisatie van onbetaald werk buiten bet eigen huishouden, in het bijzonder op het gebied van de hulpverlening. 's-Gravenhage: Nederlands Instituut voor Maarschappelijk Werk Onderzoek. 
Kwekkeboom, M.H. (1990). Het licht onder de Korenmaat. Informele zorgverlening in Nederland. 's-Gravenhage: vuGA.

64 zie ook: Lewis, J. \& B. Meredith (r988). Daughters who care: daughters caring for mothers at home. London/New York: Routledge.

65 zie: Akker, P.A.M. van den., M.H.L. van Tits \& N.M. Kok (1994). Leven met de dood. Over terminale patiënten en terminale zorg in Nederland. Houten/Zaventem: Bohn Stafleu Van Loghum. p. 2or.

66 zie bijvoorbeeld: Allen S.M. (1994). Gender differences in spousal caregiving and unmet need for care. Journal of Gerontology: Social Sciences, 187-195.

Jones, R.V.H., J. Hansford \& J. Fiske (1993). Death from cancer at home: the carers' perspective. Br. Med J, 249-251.

67 zie ook: Lewis, J. \& B. Meredith (1988). Daughters who care: daughters caring for mothers at home. London/New York: Rourledge.

68 Robinson, B. \& M. Thurnher (1979). Taking Care of Aged Parents: A Family Cycle Transition. The Gerontologist, 586-593.

69 Daal H.J. van (1990). Vrijwilligerswerk en informele hulp in Nederland. Een inventarisatie van onbetaald werk buiten het eigen huishouden, in het bijzonder op het gebied van de hulpverlening. 's-Gravenhage: Nederlands Instituur voor Maarschappelijk Werk Onderzoek.

70 zie bijvoorbeeld: Abel, E.K. (1990). Daughers caring for Elderly Parents. In: Gubrium. J.F. $8 c$ A. Sankar (eds) The home care experience. Ethnography and Policy. Newbury Park/London/New Dehli: Sage.

Brody, E.M. (1981). "Women in the middle" and Family Help to Older People'. The Gerontologist, 471-480.

Brody, E.M. (1990). Women in the middle; their parent-care years. New York: Springer.

Daurzenberg, M.G.H., J.P.M. Diederiks, H. Philipsen \& F.C.J. Stevens (1996). Vrouwen van een middengeneratie en informele zorg voor ouderen. Tijdschrift voor Geron. tologie en Geriatrie, 141-150.

Dautzenberg, M.G.H., J.P.M. Diederiks, H. Philipsen \& F.C.J. Stevens (r998). Women of a Middle Generation and Parent Care. J. of Aging and Human Development, 241-262.

Stephens M.A.P., M.M. Franks, \& A.L. Townsed (1994). Stress and reward in women's multiple roles: the case of women in the middle. Pychology and Aging, 45-52.

$7 x$ Miller, B. (1990). Gender Differences in Spouse Management of the Caregiver Role. In: Abel, E.K. \& K. Nelson (ed) Circles of Care: Work and Identity in Women's Live. Albany/U.S.A.: Srat. University of New York Press.

72 zie ook: Dowler, J.M., D.A. Jordon-Simpson \&. O. Adems (1992). Gender inequalities in Care-Giving in Canada. Health Reports, 125-136.

73 zie bijvoorbeeld: Brody, E.M. (1981). "Women in the middle" and Family Help to Older People'. The Gerontologist, 471-480.

Horowitz, A. (1985). Family Caregiving to the Frail Elderly. In: Eisdorfer C. (ed) Annual review of gerontology and geriatrics, 194-254.

74 Kwekkeboom, M.H. (1990). Het licht onder de Korenmaat. Informele zorgverlening in Nederland. 's-Gravenhage: vugA. 
75 zie bijvoorbeeld: Catalan-Fernandez., J.G., O. Pons-Sureda, A. Recober-Martinez, A. Avellà-Mestre, J,M. Carbonero-Marberti, E. Beniro-Oliver \& I Garau-Llinás (i991). Dying of cancer. The place of death and family circumstances. Medical Care, $84 \mathrm{I}-852$.

Jones, R.V.H., J. Hansford \& J. Fiske (1993). Death from cancer at home: the carers' perspective. Br. Med J, 249-25I.

76 Twigg, J. \& K. Arkin (1994). Carers Perceived. Policy and Practice in Informal Care. Buckingham-Philadelphia: Open University Press.

77 Twigg, J. \& K. Arkin (1994). Carers Perceived. Policy and Practice in Informal Care. Buckingham-Philadelphia: Open University Press.

78 Tjadens, F.L.J. \& Cl. Woldringh (1989). Informele zorg in Nederland: zelfzargproblemen, behoefte aan zorg en praktisch-instrumentele onderlinge bulp. Nijmegen: Instituut voor Toegepaste Sociale Wetenschappen.

79 zie ook: Potting, M. (1994). Sekse, ouderdom en wetenschap. De rol van sekse in de sociale gerontologie. Maastricht: Datawyse.

80 zie ook: Schure, L. M. (1995). Partners van cva patiënten. Een onderzoek naar de gevolgen van een cerebrovasculair accident voor de partner van een patiënt. Groningen: Regenboog.

81 zie bijvoorbeeld: Braun, H. (1983). Verwandschaftliche Hilfe für ältere Menschen. Eine explorative Untersuchung des Handlungsfeldes weiblicher Helfer. Zeitschrift fuir Gerontologie, 210-215.

82 Voor een overzicht van ondersteunende maatregelen voor informele verzorgers zie. bijvoorbeeld: Cuijpers, P. (1994). Ondersteuning van mantelzorgers van chronisch zieken. In: Duijnstee, M.S.H., W.J.M.J. Cuijpers, M.J. Humbert \& A.W.L. van den Dungen. Mantelzorg voor mensen met een chronische ziekte. Een literatuurstudie naar de rol van mantelzorg voor mensen met een chronische ziekte op basis van Nederlandse studies gepubliceerd in de periode 1980-1993. Zoetermeer: NCCZ. p. 147-189.

Goudriaan, G., T. Kraan \& N. de Boer (1995). Mantelzorgers steunen waarom en boe? Utrecht: Nederlands Instituut voor Zorg en Welzijn.

83 Ministerie van Welzijn, Volksgezondheid en Cultuur (1986). Nota Zorg voor Ouderen. Leidschendam: wvc. p. 59 .

84 zie bijvoorbeeld: Nationale Raad voor de Volksgezondheid (199r). Advies ondersteuning mantelzorg. Zoerermeer: NRV.

Nationale Commissie Chronisch Zieken (1996). Advies Mantelzorg voor chronisch zieken. Zoetermeer: NCcZ.

85 De voorgestelde beleidsmaatregelen beslaan een breed scala van activiteiten en zijn onder te verdelen in de: 'vervanging van een deel of het geheel van mantelzorg door andere zorg', de 'materiële' ondersteuning en de 'immateriële ondersteuning' (NRV, 1991). Her komr neer op maatregelen die een betere professionele hulpverlening aan de centrale verzorgers garanderen, maatregelen die de stressbestendigheid van de centrale verzorgers moeten verhogen en maatregelen die leiden tot betere structurele omstandigheden waarin de zorg wordt verleend (Goudriaan e.a., 1995). Abel (1990) caregoriseert deze maatregelen in financiële ondersteuning, professionele ondersteuning en stressbestendigheids-ondersteuning. 
86 rie ook: Been, M. de, M. Morée \& H. van de Velde (1996). Professionele Zorg en Mantelzorg: Ondersteuning en samenwerking. Den Haag/Leiden: PCP Zuid-Holland/ Wetenschapswinkel Leiden.

Duïnstee M.S.H. (1994). Thuis in familiezorg. Bunnik: LVT. (oratie)

Duïnustee, M.S.H. \& M.M. Govaert (1994). De dubbelrol van mantelzorgers. Leftijd, 30-33.

Nolan, M.R \& G. Grant (1989). Addressing the needs of informal carers a neglected area of nursing practice. Journal of Advanced Nursing, 950-96x.

87 Nationale Raad woor de Volksgezondheid (1991). Advies ondersteuning mantelzorg. Zoetermeer: NRV.

88 zie: ook: Goudriaan, G., T. Kraan \& N, de Boer (1995). Mantelaorgers steunen waarom en hoe? Urrecht: Nederlands Instituut voor Zorg en Welzijn.

89 In Nederland bestaat de 'verzorgingsregeling'. Alleenstaande informele verzorgers die een hupbehoevend persoon van 27 jaar of ouder in huis nemen, maken anspraak op een hogere belastingvrije som. Ook diegene die wordt verzorgd heeft hier recht op. Meer recent is her pleidooi om een fiscale vrijstelling in te voeren voor mensen die onbetaald zorg verrichten en de roep om een bejaardenbijslag voor kinderen die hun ouders verzorgen. Dit zorgforfait is te vergelijken met het bestaande arbeidskostenforfait, de bejaardenbijslag is het equivalent van de kinderbijslag. Een ander voorbeeld van financiële compensatie is een verruiming van de $A$ wBZ vergoedingen. Sondevoeding bijvoorbeeld is sinds r januari 1994 een AWBZ verstrekking. Met ingang van I januari 1994 is het dieetvergoedingenstelsel gewijzigd. Sondevoedingen voldoen aan de definitie van dieetpreparaten en kunnen voor een volledige vergoeding via de AWBZ in aanmerking komen. In de regelingen hulpmiddelen $\mathrm{A} W \mathrm{~B} Z \mathrm{Z}$ is vastgesteld dat de verzekerde een eigen bijdrage van $15 \%$ in de aanschafkosten van de toedieningmaterialen voor sondevoeding is verschuldigd van $15 \%$ met een maximum van 200 gulden per jaar.

90 Abel, E.K. (1990). Family Care of the Frail Elderly. In: Abel, E.K. \& K. Nelson (ed) Circles of Care: Work and Identicy in Women's Live. Albany/U.S.A.: Stat. University of New York Press. p. 76.

91 Werenschappelijke Raad voor het Regeringsbeleid (I993). De toekomst van de thuiszorg: 's-Gravenhage: WRRB. p. 50.

92 Ministerie van Welzijn Volksgezondheid Cultuur (1992). Dat luistert nauw. Samenvatting van de notitie Thuiszorg in de jaren negentig. Rijswijk: AWBz. p. 25.

93 zie bijvoorbeeld: Buijssen, H. (r991). De wijkverpleegkundige en de centrale verzorger. Methodische aanpak. Tijdschrift voor Ziekenverpleging, 183-186.

Buijssen, H. (r99r). De wijkverpleegkundige en de centrale verzorger. Andere vormen van hulp. Tijdschrift voor Ziekenverpleging, 234-237.

94 zie ook: Haaren, E. van (1993). Het mantelzorgsysteem: Het echtpaar P. Tijdschrift vour Ziekenverpleging, 23-24.

Haaren, E. van (1993). Het mantelzorgsysteem: Een wankel evenwicht. Tijdschrift voor Zickenverpleging, 25-28.

95 Nationale Raad voor de Volksgezondheid (1991). Advies ondersteuning mantelzorg. Zoetermeer: NRV. 
96 Dat mannen door het instellen van zorgverlof meer zullen gaan zorgen, wordt door tegenstanders van het zorgverlof weerlegd. Ze stellen dat het (weer) voornamelijk vrouwen zijn die van deze maatregelen gebruik zullen maken. Bovendien wordr de meeste zorg verleend door vrouwen van middelbare leeftijd, 'the women in the middle' of 'the sandwich generation'; zij die geen betaalde baan hebben. Het is, zo is bijvoorbeeld de mening van De Boer e.a., $(1994,20)$ een overbodige maatregel want in de huidige wet bestaan genoeg maatregelen die het opnemen van zorgverlof mogelijk maken. In artikel $16838 \mathrm{c}$, derde lid, van het burgerlijk wetboek wordt bijvoorbeeld bepaald dat een werknemer gedurende korte tijd calamiteitenverlof op kan nemen. Verder kan er een beroep worden gedaan op de Ziektewer. In her Algemeen Rijksambtenaren reglement (ARAR) is geregeld dat personeel bij ziekte van familie of huisgenoten verlof kunnen opnemen. Binnen $90 \%$ van alle CAO's zou zorgverlof geregeld zijn.

97 Blom, M.M. \& M.S.H. Duijnstee (1993). De patiënt achter de patiënt. Patiënt Care, 53-6r.

Lyke, S. van der (1995). Mantelzorg maakr pariënten. Van ideaal naar pragmarisme. Tijdschrift voor Gezondheid en Politiek, 7-10.

98 zie ook: Morée, M. (1996). De januskop van de mantelzorg. Tijdschrift voor gezondheid en politiek, $14 / 4,13-16$.

Nolan, M.R \& G. Grant (1989). Addressing the needs of informal carers a neglected area of nursing practice. Journal of Advanced Nursing, 950-961.

99 Ministerie van Welzijn Volksgezondheid Cultuur (1992). Dat luistert nauu. Samenvatting van de notitie Thuiszorg in de jaren negentig. Rijswijk: wvc. p. 25.

roo Ministerie van Welzijn Volksgezondheid Cultuur (1992). Dat luistert nauw. Samenvatting van de notitie Thuiszorg in de jaren negentig. Rijswijk: wvc. p. 2 . .

101 Twigg, J. \& K. Atkin (1994). Carers Perceived. Policy and Practice in Informal Care. Buckingham-Philadelphia: Open University Press.

102 zie bijvoorbeeld: Cantor, M.H. \& B. Hirshorn (1988). Intergenerational Transfers Wirhin the Family Context-Motivating Factors and Their Implications for Caregiving. Women \& Health: The Journal of Women's Health Care, 39-51.

I03 Abel, E.K. (1990). Informal Care for the Disabled Elderly. A Critique of Recent Literature. Research on Aging, p. 149 .

104 zie bijvoorbeeld onderzoek uit de jaren tachtig waarin de patiënt en diens familie tegelijk worden onderzocht, later is dit vaker alleen de familie oftewel de informele verzorgers.

Conkling, V.K. (1989). Continuity of Care for Cancer Patients and Families. Cancer, 290-294.

Cooge, M. \& C.G. Varricchio (1981). A pilor investigation of home health care needs of cancer parients and their families. Oncological Nursing Forum, 24-28.

Higginson, I., A. Wade \& M. McCarthy (1990). Palliative care: views of patients and their families. British Medical Journal, 277-280.

Hinds, C. (1985). The needs of families who care for parients with cancer at home: are we meeting them? Journal of Advanced Nursing, 575-581.

Jones, R.V.H., J. Hansford \& J. Fiske (1993). Death from cancer at home: the carers' perspective. Br. Med' J, 249-25I. 
Kurtz, M.E., B. Given, J.C. Kurtz \& C.W. Given (1994). The interaction of age, symptoms, and survival status on physical and mental health of patients with cancer and their families. Cancer, 2071-2078.

Laizner A.M., L.M.S. Yost, F.K. Barg \& R. Mc Corkle (1993). Needs of family caregivers of persons with cancer: a review. Semin Oncol Nurs, 114-120.

McMillan, S.C. (1996). Quality of life of primary caregivers of hospice patients with cancer. Cancer practice, 191-198.

McMillan, S.C. \& M. Mahon (1994) The impact of hospice services on the quality of life of primary caregivers. Oncol. Nurs. Forum, 1189-1195.

Sterz, K.M. (1987). Caregiving Demands During Advances Cancer-the Spouse Needs. Cancer Nursing, 260-268.

Sykes, N.P., S.E. Pearson \& S. Chell (r992). Quality of care of the terminally ill: the carer's perspective. Palliative Medicine, 227-236.

Wingate A.L. \& N.R. Lackey (1989). A description of the needs of noninstitutionalized cancer patients and their primary caregivers. Cancer Nurs, 216-225.

Woods, N.F., Lewis F.M. \& E.S. Ellison (1989). Living with cancer: family experiences. Cancer Nursing, 28-33.

tos Boer, A.H. de., J.C. Hessing-Wagner, M. Moorz \& I.S. Schoemakers-Salkinoja (1994). Informele zorg: een verkenning wan huidige en toekomstige ontwikkelingen. Rijswijk: Sociaal en Cultureel Planbureau.

106 Nolan, M.R \& G. Grant ( 1989$)$. Addressing the needs of informal carers a neglected asea of nursing practice. Journal of Advanced Nursing, 950-961.

107 Opie, A. (1994). The instability of the Caring Body: Gender and Caregivers of Confused Older People. Qualitative Health Research, 31-50.

108 Janssen, T. (1985). Thuiszorg bij ondere mensen. Nijmegen: Sociologisch Instituut kU. Janssen, T. (1988). De betekenis van de familie voor de centrale verzorg(st)er van hulpbehoevende oudere mensen. Tijdschrift voor Gerontologie en Geriatrie, 185-191.

Janssen, T. (1988). Zorg om mantelzorg. Verzorg(st)er van de invaliderende oudere mens. Tijdschrift voor Ziekenverpleging, 169-174.

109 zie bijvoorbeeld: Janssen, T. (1988). Zorg om mantelzorg. Verzorg(st)er van de invaliderende oudere mens. Tijdschrift voor Ziekenverpleging, 169-174.

Lewis, J. \& B. Meredith (1988). Daughters who care; daughters caring for mothers at bome. London/New York: Routledge.

Ungerson, C. (1987). Policy is personal; sex, gender and informal care. London: Tavistock Publications LTD.

no zie bijvoorbeeld: Opie, A. (r994). The instability of the Caring Body: Gender and Caregivers of Confused Older People. Qualitative Health Research, $31-50$.

III Buis, M. (1990). Ondersteuning wan mantelzorg Een staalkaart van initiatieven. Utrecht: NIzw. p. ro.

112 zie bijvoorbeeld: Kuyper, M. B. (1993). Op de achtergrond. Een onderzoek naar de problemen van partners van patiënten met een chronische ziekte. Amsterdam: Thesis Publishers.

II3 zie bijvoorbeeld: Nolan, M.R \& G. Grant (I989). Addressing the needs of informal. carers a neglected area of nursing practice. Journal of Advanced Nursing, 950-96r. 
II4 zie bijvoorbeeld: Kuyper, M. B. (1993). Op de achtergrond. Een onderzoek naar de problemen van partners van patiënten met een chronische ziekte. Amsterdam: Thesis Publishers. p. 80 .

Miller, B. (1990). Gender Differences in Spouse Management of the Caregiver Role. In: Abel, E.K. \& K. Nelson (ed) Circles of Care: Work and Identity in Women's Live. Albany/u.S.A.: Stat. University of New York Press.

IIs Ungerson, C. (1987). Policy is personal; sex, gender and informal care. London: Tavistock Publications LTD.

116 zie bijvoorbeeld: Been, M. de, M. Morée \& H. van de Velde (1996). Professionele Zorg en Mantelzong: Ondersteuning en samenwerking. Den Haag/Leiden: PCP ZuidHolland/Wetenschapswinkel Leiden.

II7 zie: Nolan, M.R \& G. Grant (1989). Addressing the needs of informal carers a neglected area of nursing practice. Journal of Advanced Nursing; 950-96r.

I18 zie: Berry, G.L., S.H. Zaric \& V.X. Rabarin (1991). Caregiver Activity on Respite and Nonrespite Days: A Comparison of Two Service Approaches. The Gerontologist, $830-835$.

in zie ook analyse van: Kuhlman G.J., H.S. Wilson, S.A. Hutchinson \& M. Wallhagen (1991). Alzheimer Disease and family Caregiving: Critical Synthesis of the Literature and Research Agenda. Nursing Research, 331-337.

I20 voorbeeld artikelen relarie: verzorgers van ouderen en stress.

Archbold, P.G., B.J. Stewart, M.R. Greenlick, T. Harvarh (1990). Muruality and Prepardness as Prediciors of Caregiver Role Strain. Research in Nursing of Health, $375-384$.

Ballie, V., J.S. Norbeck \& L-E. A. Barnes (i988). Stress, Social Suppor, and Psychological Distress of Family Caregivers of the Elderly. Nursing Research, 2r7-222.

Barusch, A.S. (1988). Problems and Coping Strategies of Elderly Spouse Caregivers. The Gerontologist, 677-685.

Bull, M.J. (1990). Factors Influencing Family Caregivers Burden and Health. Western Journal of Nursing Research,758-776.

Cantor, M.H. (1983). Strain Among Caregivers: A Study of Experience in the United States. The Gerontologist, 597-604.

Francell, C.G. V.S. Conn, D.P. Gray (1988). Families' Perceptions of Burden of Care for Chronic Mentally III Relatives. Hospital and Community Psychiatry. 1296-r300.

Gwyther, L.P. \& M.A. Marteson (1983). Care for the caregivers. Journal of Cierontological Nursing, 93-95.

Harrison, D.S. \& K.D. Cole (r991). Family Dynamics and Caregiver burden in Home Health Care. Clinics in Geriatric Medicine, 817-829.

Killeen, M. (ro9o). The Infuence of Stress and Coping on Family Caregivers' Perceptions of Health. Int. Journal Aging and Human Dewelopment, 197-211.

Zarit, S.H., K.E. Reever, \& J. Bach Peterson (1980). Relatives of the impaired elderly: Correlates of feelings of burden. The Gerontologist, 269-655.

Zarit, S.H., P.A. Todd, \& J.M. Zarir (1986). Subjecrive burden of husbands and wives as caregivers: A longitudinal sudy. The Gerontologist, 260-266.

voorbeeld artikelen relacie: verzorgers van patiënten met kanker en stress. 
Carey, P.J., M.T. Oberst, M.A. McCubbin, S.H. Hughes (1991). Appraisal and caregiving burden in family members caring for parients receiving chemotherapy. Oncol Nurs Forum, 134i-1348.

Cawley, M.M., E.K. Gerdts (1988). Establishing a Cancer Caregivers Program. Cancer Nursing, 267-273.

Harrison, D.S. \& K.D. Cole (I99i). Family Dynamics and Caregiver burden in Home Health Care. Clinics in Geriatric Medicine, 817-829.

Hileman, J.W. \& N.R. Lackey (1990). Self-Identified Needs of Patiens With Cancer at Home and Their Home Caregivers: A Descriptive Study. Oncological Nursing Forum, 907-913.

Hileman, J.W., N.R. Lackey \& R.S. Hassanein (1992). Identifying the needs of Home Caregivers of Patient with Cancer. Oncology Nursing Forum, 771-777.

Hinds, C. (1992). Suffering: a relatively unexplored phenomenon among family caregivers of non-institutionalized parients with cancer. Journal of Advanced Nursing, 918-925.

Jensen, S. \& B.A. Given (1991). Farigue affecting family caregivers of cancer patients. Cancer Nurs, 181-187.

Kirby, D. (1987). Support for the silent suffers. Nursing Times, 43-44.

Lewandowski, W. \& S.L. Jones (1988). 'The family with cancer' Cancer Nursing, 313-321.

Mohide, E.A., G.W. Torrance, D.L. Streiner, D.M. Pringle \& R. Gilbert (1988). Measuring the well being of family caregivers using the time trade-off technique. /. Clinical Epidemiology, 475-482.

Nordlicht, S. (1982). The Family of the Cancer Parient NY State J Med, 1845-1846.

Oberst, M.T., K.A. Gass \& S.E. Ward (1989). Caregiving demands and appraisal of stress among family caregivers. Cancer Nursing, 209-215.

Schott-Baer, D. (1993). Dependent care, caregiver burden, and self-care agency of spouse caregivers. Cancer Nurs, 230-236.

Stetz, K.M. (1987). Caregiving Demands During Advances Cancer- the Spouse Needs. Cancer Nursing, 260-268.

121 In het onderzoek van Witteveen e.a. (1996) bijvoorbeeld is men nagegaan of de informele verzorgers die extra zorg konden geven die gepaard gaat met de inbreng van technologie thuis. Hieruit blijkt dat er in deze studie specifieke aandacht is voor de verzorgers, maar wel vanuir het idee dat zij 'de achilleshiel' zijn. In deze studie bleek de draagkracht van de verzorgers toereikend. Dit leidde men af uit het feit dat er geen heropnames waren die samenhingen met de belasting van de verzorgers.

122 zie bijvoorbeeld: Cox, S. (1991). Mantelzorg belast en gesteund. Tilburg: Provinciaal Opbouworgaan Noord-Brabant.

I23 zie ook: Abel, E.K. (1990). Informal Care for the Disabled Elderly. A Critique of Recent Literature. Research on Aging, 139-157.

Horowirz, A. (1985). Family Caregiving to the Frail Elderly. In: Eisdorfer C. (ed) Annual review of gerantology and' geriatrics, 194-254.

124 zie ook: Tijssen, I.M.J.G. \& E. Elsinga (1990). Evaluatie-onderzoek op het terrein van de gezondheidszorg. In: Maarse, J.A.M. \& I.M. Mur-Veeman (red) Beleid en beheer in 
de gezondheidszorg. Problemen, structuren, processen en effecten. Assen/Maastricht: Van Gorcum. p. 215-234.

n.25 zie voor verschillende kritieken bijvoorbeeld:

Abma, T.A. (1991). Drie kemproblemen van beleidsevaluarie doordacht vanuit de naturalistische benadering. Beleid en Maatschappij, 226-236.

Abma, T.A. (r992). Beleidsevaluatie volgens het politiek-sociale leermodel. Vernieuwend onderzoek naar Sociale Vernieuwing in Rotterdam. Management en Organisatie, 423-440.

Abma, T.A. (1993). Voorbij de technocratische oriëntate in beleidsevaluatie. Beleid en Maatschappij, 244-254.

Kensen, S. (1999). Sturen op variatie. Sociale Vernieuwing en de deense variant als bronnew van inspiratie. 's-Gravenhage: vwg Uitgeverij.

Twist, M. van (1994). Verbale Verniewving. Aantekeningen over de kunst van bestuurskunde'-s Gravenhage: vuGA.

126 zie ook: Abma, T.A. (1991). Drie kernproblemen van beleidsevaluatie doordacht vanuir de naruralistische benadering. Beleid en Maatschappij, 226-236.

Abma, T.A. (1992). Beleidsevaluarie volgens het politiek-sociale leermodel. Vernieuwend onderzoek naar Sociale Vernieuwing in Rorterdam. Management en Organisatie, 423-440.

Guba, E.G. \& Y.S. Lincoln (1987). The countenances of fourth generation evaluation: Description, judgement and negotiation. In: Corday, D.S. \& M.W. Lipsey (ed). Evaluation Studies Review Annual, Newburry Park: Sage Publication.

Lincoln, Y.S. \& E.G. Guba (1985). Naturalistic inquire. Newbury Park/London/New Delhi: Sage Publications.

\section{Noten bij hoofdstuk 3}

I. In 1970 vonden $19 \%$ van alle sterfgevallen in een ziekenhuis plaats, en ruim de helft thuis. In 1990 zijn ongeveer $27 \%$ van de mannen die kanker hadden thuis overleden en $23 \%$ van de vrouwen. In 1995 was her (toraal) aantal sterfgevallen dat in een ziekenhuis plaats vond toegenomen tot $35 \%$ Dit ondanks het extramuralisatie beleid. Een verklaring wordt gezocht in de verdergaande medicalisering van de dood en de hoop dat het ziekenhuis zekerheid biedr (Timmermans, 1997).

2 Ministerie van Volksgezondheid Welzijn en Sport (1997). Thuiszorg en zorg thuis, kansen voor de toekomst. Rijswijk: vws. p. 19.

3 Ministeric van Volksgezondheid Welzijn en Sport (r997). Thuiszorg en zorg thuis, kansen voor de soekomst. Rijswijk: vws. p. 6.

4 Ministerie van Volksgezondheid Welzijn en Sport (1997). Thuiszorg en zorg thuis, kansen voor de toekomst. Rijswijk: vws. p. II

5 Ministerie van Volksgezondheid Welzijn en Sport (1997). Thuiszorg en zorg thuis, kansen voor de toekomst. Rijswijk: vws. p. 19.

6 Ziekenfondsraad (1985). Advies Terminale Thuiszorg. Amstelveen: ZFr. p. 12.

7 Ziekenfondsraad (1991). Advies invoering intensieve thuiszorg Amstelveen: ZFR. p. 13. 
Wetenschappelijke Raad voor het Regeringsbeleid (1993). De toekomst van de thuiszorg. 's-Gravenhage: wrRB. p. 24.

zie: Nationale Raad voor de Volksgezondheid (1989). Discussienota Thuiszorg. Zoetermeer: NRV.

10 Ministerie van Welzijn, Volksgezondheid en Cultuur (1988). Verandering Verzekerd. Leidschendam/Rijswijk: wrc. p. 38.

iI Ministerie van Welzijn Volksgezondheid Cultuur (1992). Dat luistert naww. Samenvatting van de notitie Thuiszorg in de jaren negentig. Rijswijk: wvc. p. 8.

12 Gezondheidsraad (1991). Advies thuiszorg voor patiënten met kanker: 's-Gravenhage: GR. p. 59 .

13 Ministerie van Volksgezondheid Welzijn en Sport (1997). Thuiszorg en zorg thuis, kansen voor de tockomst. Rüswijk: vws. p. 27.

14 Gezondheidsraad (I99r). Advies thuiszorg voor patiënten met kanker: 's-Gravenhage: GR. p. 39 .

Is zie ook: Akker, P.A.M. van den., M.H.L. van Tits \& N.M. Kok (1994). Leven met de dood. Over terminale patiënten en terminale zorg in Nederland. Houten/Zaventem: Bohn Stafleu Van Loghum. p. 128.

16 Ziekenfondsraad (1985). Advies Terminale Thuiszorg. Amstelveen: ZFr. p. 13.

17 Ministerie van Welzijn, Volksgezondheid Cultuur (1983). Nota Eerstelijnszorg. Leidschendam: wvc. p. 16.

18 Ministerie van Welzijn Volksgezondheid Cultuur (1992). Dat luistert nauw. Samenvatting van de notitie Thuiszorg in de jaren negentig. Rijswijk: WvC. p. 7.

I9 Nationale Raad voor de Volksgezondheid (1985). Advies kwaliteit, organisatie en financiering thuiszorg. Zoetermeer: NRV. p. 27.

20 Nationale Raad voor de Volksgezondheid (1989). Discussienota substitutie in de gezondheidszorg. Zoetermeer: NRV. p. 22.

2 I Nationale Raad voor de Volksgezondheid (1991). Advies ondersteuning mantelzorg. Zoetermeer: NRV. P. 32.

22 Nationale Raad voor de Volksgezondheid (1989). Discussienota Thuiszorg. Zoetermeer: NRV. p. 22.

23 Ministerie van Welzijn Volksgezondheid Cultuur (1992). Dat luistert nauw. Samenvatting van de notitie Thuiszorg in de jaren negentig. Rijswijk: WvC. p. 25.

24 Werenschappelijke Raad voor het Regeringsbeleid (i993). De toekomst van de thuiszorg. 's-Gravenhage: WRRB. p. IO.

25 Ministerie van Volksgezondheid Welzijn en Sport (1997). Thuiszorg en zorg thwis, kansen voor de tockomst. Rijswijk: vws. p. 16.

26 Nationale Raad voor de Volksgezondheid (1991). Advies ondersteuning mantelzorg. Zoetermeer: NRV. p. 27.

27 Nederlandse Gezinsraad/sDG (1996). Mantelzorg moet mogen. Den Haag: NGR. p. I3.

28 Nederlandse Gezinsraad/sDg (i996). Mantelzorg moet mogen. Den Haag: NGR.

29 zie ook: Frankenberg, R. (1992). Your Time or Mine: temporal contradicrions of biomedical pracrice. In: Frankenberg, R. (ed) (1992). Time Health \& Medicine, London: Sage. 
zie bijvoorbeeld: Akker, P.A.M. van den., M.H.L. van Tirs \& N.M. Kok (1994). Leven met de dood. Over terminale patiënten en terminale zorg in Nederland. Houten/ Zaventem: Bohn Stafleu Van Loghum.

Daal H.J. van (1990). Vrijwilligerswerk en informele hulp in Nederland. Een inventarisatie van onbetaald werk buiten het eigen huishouden, in het bijzonder op het gebied! van de hulpverlening. 's-Gravenhage: Nederlands Instituut voor Maatschappelijk Werk Onderzoek.

Tjadens, F.L.J. \& Cl. Woldringh (1989). Informele zorg in Nederland: zelfzorgproblemen, behoefte aan zorg en praktisch-instrumentele onderlinge hulp. Nijmegen: Instituut voor Toegepaste Sociale Wetenschappen.

3I Akker, P.A.M. van den., M.H.L. van Tirs \& N.M. Kok (1994). Leven met de dood. Over terminale patiënten en terminale zorg in Nederland. Houten/Zaventem: Bohn Stafleu Van Loghum. p. 128.

32 Ministerie van Volksgezondheid Welzijn en Sport (1997). Thuiszorg en zorg thuis, kansen voor de toekomst. Rijswijk: vws. p. 7 .

33 Ministerie van Welzijn, Volksgezondheid en Cultuur (1986). Nota Zorg voor Ouderen. Leidschendam: wvc. p. 56.

34 Nationale Raad voor de Volksgezondheid (1985). Advies kwaliteit, organisatie en financiering thuiszorg. Zoetermeer: NRV. p. 23.

35 Gezondheidsraad (1991). Advies thuiszorg voor patiënten met kanker. 's-Gravenhage: GR. P. 59.

36 Nationale Raad voor de Volksgezondheid (1985). Advies kwaliteit, organisatie en financiering thuiszorg. Zoetermeer: NRV. p. 20.

37 Ministerie van Welzijn Volksgezondheid Cultuur (1992). Dat luistert nauw Samenvatting van de notitie Thuiszorg in de jaren negentig. Rijswijk: wvc. p. 9.

38 Nationale Raad voor de Volksgezondheid (1989). Discussienota Thuiszorg. Zoetermeer: NRV. p. 8.

39 zie bijvoorbeeld: Nationale Raad voor de Volksgezondheid (1991). Advies ondersteuning mantelzorg. Zoetermeer: NRV.

40 Ministerie van Welzijn Volksgezondheid Culruur (1992). Dat luistert nauw. Samenvatting van de notitie Thuiszorg in de jaren negentig. Rijswijk: wvc. p. 25.

41 zie: Nationale Raad voor de Volksgezondheid (1985). Advies kwaliteit, organisatie en financiering thuiszorg. Zoetermeer: NRV. p. 20.

42 Ministerie van Welzijn Volksgezondheid Cultuur (1992). Dat histert nauw. Samenvatting van de notitie Thuiszorg in de jaren negentig. Rijswijk: wvc. p. 25.

43 'Tweede Kamer (1994-1995). Gezond en wel. Het kader van bet volksgezondheidsbeleia! 1995-1998. 's-Gravenhage: Staatsuitgeverij. p. 126.

44 Breed Indicatie Overleg (1997). Modelprotocol geintegreerde indicatiestelling voor het terrein van wonen, welzijn en zorg. VNG: Den Haag. p. 20.

45 Ministerie van Welzijn, Volksgezondheid Cultuur (1983). Nora Eerstelijnszorg. Leidschendam: wrc. p. 45 .

46 Ziekenfondsraad (1985). Advies Terminale Thuiszorg. Amstelveen: ZFR. p. 7.

47 Ministerie van Welzijn Volksgezondheid Culruur (1992). Dat luistert nauw. Samenvatting van de notitie Thuiszorg in de jaren negentig. Rijswijk: wvc. p. 19. 
48 Breed Indicatie Overleg (1997). Modelprotocol geïntegreerde indicatiestelling voor het terrein van wonen, welzijn en zorg. vNG: Den Haag. p. 20.

49 Nationale Raad voor de Volksgezondheid (1985). Advies kwaliteit, organisatie en financiering thuiszorg. Zoetermeer: NRV. p. 20.

50 Wetenschappelijke Raad voor het Regeringsbeleid (1993). De toekomst van de thuiszorg. 's-Gravenhage: wrRB. p. 24.

51 Ziekenfondsraad (1985). Advies Terminale Thuiszorg. Amstelveen: zFr. p. 7.

52 Ziekenfondsraad (1985). Advies Terminale Thuiszorg. Amstelveen: ZFR. p. Io.

53 zie ook: Abel, E.K. \& M.K. Nelson (1990). Circles of Care: An Introductory Essay. In: Abel, E.K. \& K. Nelson (ed) Circles of Care: Work and Identity in Women's Live. Albany/U.S.A.: Srat. Universicy of New York Press. p. 8.

54 zie bijvoorbeeld: Gezondheidsraad (1991). Advies thuiszorg voor patiënten met kanker. 's Gravenhage: GR.

55 zie bijvoorbeeld ook: Heinsbroek, N. \& H. van Tilburg (1996). Zorgen voor mantelzorgers. Handreikingen om mantelargers te onderstemen. Utrecht: SDG.

56 Wetenschappelijke Raad voor her Regeringsbeleid (1993). De tockomst van de thuiszorg. 's-Gravenhage: WRRB. p. I6.

57 Ziekenfondsraad (1985). Advies Terminale Thriszorg. Amstelveen: ZFR. p. 13.

58 zie ook: Rubinstein, R.L. (1990). Culture and Disorder in the Home Care Experience. The Home as a Sickroom. Gubrium J.F. \& A. Sankar (eds) The home care experience. Ethnography and Policy. Newbury Park/London/New Dehli: Sage. P. 37-59.

59 zie ook: Akker, P.A.M. van den., M.H.L. van Tits \& N.M. Kok (1994). Leven met de dood. Over terminale patiënten en terminale zorg in Nederland. Houten/Zaventem: Bohn Scafleu Van Loghum. p. 55.

60 zie ook: Albert, S.M. (1990). The Dependent Elderly. Home Health Care, and Strategies of Household Adaptation. In: Gubrium J.F. \& A. Sankar (eds) The home care experience. Ethnography and Policy. Newbury Park/London/New Dehli: Sage.

61 zie ook: Barusch, A.S. (1988). Problems and Coping Strategies of Elderly Spouse Caregivers. The Gerontologist, 677-685.

62 zie ook: Schure, L. M. (1995). Partners van cva patiënten. Een onderzoek naar de gevolgen van een cerebrovasculair accident voor de partner van een patiënt. Groningen: Regenboog.

63 zie ook: Bull, M.J. (1992). Managing the Transition From Hospital to Home. Qualitative Health Research, p. 30.

64 Bull, M.J. (1992). Managing the Transition From Hospital to Homc. Qualitative Health Research, 27-41.

6s zie ook: Kuyper, M. B. (1993). Op de achtergrond. Een onderzoek naar de problemen van partners van patienten met een chronische siekte. Amsterdam: Thesis Publishers.

66 zie ook: Barusch, A.S. (1988). Problems and Coping Strategies of Elderly Spouse Caregivers. The Gerontologist, p. 682.

Kuyper, M. B. (1993). Op de achtergrond. Een onderzoek naar de problemen van partners van patiënten met ecn chronische ziekte. Amsterdam: Thesis Publishers. p. 58.

67 zie ook: Courtens, A.M. (1993). Kenmerken van zorg en kwaliteit van leven bij patiënten met kanker. Maastricht: UPM. 
68 Courtens, A.M. (1993). Kenmerken van zorg en kwaliteit van leven bij patiënten met kanker. Maastricht: UPM.

69 zie: Keulartz, J. (1987). Van bestraffing naar behandeling. Een inleiding in de sociologie van de hulpverlening. Amsterdam/Meppel: Boom. p. 91-119.

70 Studies over de zorgpraktijk van buitenshuis werkende moeders concluderen eveneens dat zorg (voor kinderen) en werk niet per definitie belastend hoeft te zijn. zie bijvoorbeeld: Morée, M. (1992). 'Mijn kinderen hebben er niets van gemerkt'. Buitenshuis werkende moeders tussen roso en nu. Utrecht: Jan van Arkel.

Groenedijk, H. (1998) Werken en zorgen: de moeite waard. Een onderzoek naar het welbevinden van buitenshuis werkende moeders. Utrecht: Jan van Arkel.

Knyn, T. (1992). Balanceren op ongelijke leggers: veranderingen in zorg en arbeidsverhoudingen tussen de seksen. Tijdschrift voor Vrouwenstudies, 497-509.

71 zie ook: McMillan, S.C. \& M. Mahon (1994) The impact of hospice services on the quality of life of primary caregivers. Oncol. Nurs. Forum, 1189-1195.

72 vergelijk: Bekker, M. (1995). Werk en kinderen: dubbele belasting of een gezonde combinatie? Tijdschrift voor Vrouwenstudies, 397-413.

73 Oberst, M.T., K.A. Gass \& S.E. Ward (1989). Caregiving demands and appraisal of stress among family caregivers. Cancer Nursing, 209-215.

74 Hier staan studies van bijvoorbeeld Jayabos e.a. (1991) tegenover. Uit deze studie blijkr dat de informele verzorgers zich in toenemende mate verantwoordelijk voelen wanneer thuiszorgtechnologie ingezet wordt bij de behandeling van hun kind met kanker thuis. Ondanks deze extra verantwoordelijkheid geven zij toch de voorkeur voor thuisbehandeling boven ziekenhuisbehandeling. Ook volgens de studie van Close e.a. (1995) verstoort een chemotherapie voor kinderen thuis het gezinsleven minder dan een ziekenhuisbehandeling.

75 zie ook: Hirschfeld, M. (1983). 'Homecare versus institutionalization: family-caregiving and senile brain disease.' Int. I. Nursing Studies, 23-32.

76 uit: Manschor, H. (1994). Kwestbare autonomie: Over afhankelijkheid en onafhankelijkheid in de ethiek van de zorg. In: Manschor, H. \& M. Verkerk (1994) Ethiek van de zorg. Een discussie. Amsterdam: Boom. p. 100.

\section{Noten bij hoofdstuk 4}

I Naast professionele zorgverleners en informele verzorgers wordt ook wel de groep vrijwilligers onderscheiden. Beleidsmakers omschrijven vrijwilligers als een georganiseerde vorm van informele zorg of mantelzorg. Het is werk dat in enig georganiseerd verband, onverplicht en onberaald wordt verricht ten behoeve van anderen of de samenleving. In dit proefschrift en hoofdstuk laat ik, gezien de vraagstelling, deze groep verzorgers buiten beschouwing.

2 Nationale Raad voor de Volksgezondheid/College voor Ziekenhuisvoorzieningen (1994). Indicatiestelling en zorg op maat. Zoetermeer: NRv p. 9-10.

3 Nederlandse Gezinsraad/sDG (1996). Mantelzorg moet mogen. Den Haag: NGR. 
4 zie: Breed Indicarie Overleg (1997). Modelprotocol geïntegreerde indicatiestelling voor het terrein van wonen, welaijn en zorg. vNG: Den Haag.

5 Breed Indicatic Overleg (1997). Modelprotocol geintegreerde indicatiestelling voor bet terrein wan woner, welzijn en zorg. VNG: Den Haag.

6 Breed Indicatie Overleg (1997). Modelprotocol geïntegreerde indicatiestelling voor het terrein van wonen, welaijn en zorg. vNG: Den Haag. p. 20.

7 Verschillende onderzoekers, de vrouwenbeweging en belangenverenigingen voor informele verzorgers pleiten echter voor herziening van her uirgangspunt professionele zorg pas in te zetten als de informele zorg niet meer kan. Volgens hen zou de inzer van informele zorg minder vanzelfsprekend moeten zijn. Zij wensen dat het beleid professionele zorgverlening nier langer als aanvulling op informele zorg beschouwt, maar dat informele zorg een aanvulling is op professionele zorg.

8 zie ook: Enarson, E. (1990). Experts and Caregivers: Perspecrives on Underground Day Care. In: Abel, E.K. \& K. Nelson (ed) Circles of Care: Work and Identity in Women's Live. Albany/U.S.A.: Stat. University of New York Press.

9 Nationale Raad voor de Volksgezondheid (1991). Advies ondersteuning mantelzorg. Zoetermeer: NRV. p. 8.

Io Nationale Raad voor de Volksgezondheid (r991). Advies ondersteuning mantelzorg. Zoetermeer: NRV. p. 8.

II Ziekenfondsraad (1985). Advies Terminale Thuiszorg. Amstelveen: zFr.

12 Nationale Raad voor de Volksgezondheid (199r). Advies ondersteuning mantelzorg. Zoetermeer: NRV. p. 39.

13 Ministerie van Welzijn, Volksgezondheid Cultuur (1983). Nota Eerstelijnszorg. Leidschendam: wvc. p. 12.

14 Ministerie van Welzijn, Volksgezondheid Cultuur (1983). Nota Eerstelijnszorg. Leidschendam: wrc. p. 6.

15 Ziekenfondsraad (1985). Advies Terminale Thuiszorg. Amstelveen: ZFr. p. Io.

16 Ziekenfondsraad (1985). Advies Terminale Thuiszorg. Amstelveen: ZFR. p. I5.

17 Tweede Kamer (1994-1995). Gezond en wel. Het kader van het volksgezondheidsbeleid 1995-1998. 's-Gravenhage: Staatsuitgeverij.

I8 Nationale Raad voor de Volksgezondheid (1991). Advies ondersteuning mantelzorg. Zoetermeer: NRV. p. 29.

19 Helmond, T. van (1996). De verhouding mantelzorg-professionele zorg. In: N. Heinsbrock \& H. van Tilburg (1996). 2. Utrechs: sDG. p. 29-35.

20 Nationale Raad voor de Volksgezondheid (1989). Discussienota Thuiszorg. Zoetermeer: NRV. P. 49.

21 Nationale Raad voor de Volksgezondheid (1989). Discusienota Thuiszorg. Zoerermeer: NRV. p. 49.

22 Nationale Raad voor de Volksgezondheid (1991). Advies ondersteuning mantelzorg. Zoetermeer: NRV. p. I2.

23 Ministcric van Welzijn, Volksgezondheid Cultuur (1983). Nota Eerstelijnszorg. Leidschendam: wvc. p. 14 .

24 Ministerie van Welzijn, Volksgezondheid Cultuur (1983). Nota Eerstelijnszorg. Leidschendam: wvc. p. 93. 

Leidschendam: wvc. p. 12.

26 Nationale Raad voor de Volksgezondheid (1991). Advies ondersteuning mantelzorg. Zoetermeer: NRV. p. 18.

27 Ziekenfondsraad (1985). Advies Terminale Thuiszorg. Amstelveen: ZFr. p. 10.

28 Ministerie van Welzijn Volksgezondheid Cultuur (1992). Dat luistert nauw. Samenvatting van de notitie Thuiszorg in de jaren negentig. Rijswijk: wvc. p. 19.

29) Ministerie van Welzijn, Volksgezondheid Cultuur (1983). Nota Eerstelijnszorg. Leidschendam: wvc. p. 17.

30 Ministerie van Welzijn Volksgezondheid Cultuur (1992). Dat luistert nauw. Samenvatting van de notitie Thuiszorg in de jaren negentig. Rijswijk: wvc. p. 25.

3 B Breed Indicatie Overleg (1997). Modelprotocol geintegreerde indicatiestelling voor het terrein van wonen, welzijn en zorg. vNG: Den Haag. p. 2 I.

32 In de beschrijving van de relatie tussen professionele verzorger en informele verzorger is tegelijk een gender-verhouding geïntroduceerd. Zorgprofessionals worden geassocieerd met 'mannelijke waarden' als salaris, formeel erkende opleiding, kennis en rationalireit. Hiermee benadrukken beleidsmakers de instrumentele kant van zorg. Informele zorg daarentegen wordt geassocieerd mer 'vrouwelijke waarden', ingevuld als spontaniteit, nabijheid en emotionaliteit. Hierbij wordt de relationele kant van zorg benadrukt (zie verder hoofdstuk s).

33 zie ook: Nolan, M.R \& G. Grant (1989). Addressing the needs of informal carers a neglected area of nursing practice. Journal of Advanced Nursing, 950-961.

34 zie ook: Blank, J.J., L. Clark \& A.J. Longman et al. (1989). Perceived home care needs of cancer patients and their caregivers. Cancer Nursing, 78-84.

35 Volgens Nolan and Grant (1989) besteden weinig professionele verzorgenden expliciet aandacht aan ondersteuning van informele verzorgers. Volgens deze auteurs besteden wijkverpleegkundigen minder dan $2 \%$ van hun tijd aan her instrueren en adviseren van de informele zorg. $\mathrm{Zij}$ zouden weinig prioriteit hieraan geven, omdat ze dit nier als de crux van hun professionele werk beschouwen. Ook stellen de auteurs, dat verpleegkundigen niet erg geïnteresseerd zijn in en kennis hebben van zieken 'die niet meer beter worden' en hun verzorgers. Professionals zouden informele verzorgers die aandacht vragen voor hun eigen problematiek snel als 'lastige verzorgers' percipiëren. Het gevolg is dat zij het ondersteunen van deze verzorgers delegeren aan minder geschoolde collega's. Het ondersteunen van informele verzorgers in de vorm van her geven van informatic en educatie, zo concluderen ze zou cen ondergeschoven aandachtsgebied bij verpleegkundigen zijn.

36 zie ook: Verkerk, M. (1994). Zorg of conrract: een andere ethick. In: Manschor, H. \& M. Verkerk (1994). Ethiek van de zorg. Een discussie. Amsterdam: Boom. p. 53-74.

37 zie ook: Brody, E.M. (1981). "Women in the middle" and Family Help to Older People'. The Gerontologist, 471-480.

Corbin, J. \& A. Strauss (i988). Unending work and care San Francisco: Jossey-Bass. Corbin, J.M. \& A. Strauss (1990). Making Arrangements The Key to Home Care. In: Gubrium J.F. \& A. Sankar (eds) The home care experience. Ethnography and Policy. Newbury Park/London/New Dehli: Sage. p. 59-75. 
38 Zie artikel waarin de beperkte reikwijdte van professionele (zorg)kennis wordt getoond: Goode, D.A. (1990). On understanding without words: Communication between a deaf-blind child and her parents. Human Studies, $1-37$.

39 vergelijk: Swaan, A. de (1990). Zorg en de Staat. Welzijn, onderwijs en gezondheidszorg in Europe en de Verenigde Staten in de nieuwe tijd. Amsterdam: Bert Bakker. p. 244-257.

40 De Been e.a, (1996) stellen in dit verband dar informele verzorgers professionele ondersteuning niet zonder meer als succesvol ervaren. Er dient eerst aan cen aantal eisen te zijn voldaan. Zo moeten succesvolle professionele verzorgenden op de eerste plaats veel weten over de context waarin hun werk plaats vindt. Gederailleerde kennis van het leven van de zieke en diens verzorger is nodig. Daarbij moeten ze de informele verzorger zo onopvallend mogelijk bijstand geven en bovendien blijk geven van waardering voor de deskundigheid van de informele verzorgers. Tot slot moet niet alleen kennis over de ziekte en het ziekteproces als belangrijk worden gedefinieerd, maar vooral of de inzet van die kennis met respect voor de zieke en de verzorger gebeurt.

41 Zie bijwoorbeeld: Swaan, A. de (1990). Zorg en de Staat. Welzijn, onderwijs en gezondheidszarg in Europa en de Verenigde Staten in de nieuwe tijd. Amsterdam: Bert Bakker. p. $244-257$.

42 Ministerie van Welzijn, Volksgezondheid Cultuur (1983). Nota Eerstelijnszorg. Leidschendam: wvc. p. 12.

43 Narionale Raad voor de Volksgezondheid (1989). Discussienota Thuiszorg. Zoetermeer: NRV. p. 53 .

44 Ministerie van Welzijn, Volksgezondheid Cultuur (1983). Nota Eerstelijnszorg. Leidschendam: wvc. p. 6.

45 Ministerie van Welzijn, Volksgezondheid Cultuur (1983). Nota Eerstelijnszorg. Leidschendam: wvC. p. 46.

46 Ministerie van Welzijn, Volksgezondheid Cultuur (1983). Nota Eerstelijnszorg. Leidschendam: wro. p. 3.

47 Ministeric van Welzijn Volksgezondheid Cultuur (1992). Dat hissert nauus Samenvatting van de notitie Thuiszorg in de jaren negentig. Rijswijk: wvc. p. 10.

48 Ministerie van Volksgezondheid Welzijn en Sport (1997). Thuiszorg en zorg thuis, kansen voor de tockomst. Rijswijk: vws. p. 6.

49 Ministeric van Volksgezondheid Welzijn en Sport (r997). Thuiszorg en zorg thuis, kansen voor de toekomst. Rijswijk: wws. p. 6.

so Zickenfondsraad (1985). Aduies Terminale Thuiszorg. Amstelveen: Zfr. p. 10.

S1 Ministerie van Welzijn, Volksgezondheid Cultuur (x983). Nota Eerstelijnszorg. Leidschendam: wvc. p. 45.

52 Wetenschappelijke Raad voor her Regeringsbeleid (1993). De toekomst van de thuiszorg. 's-Gravenhage: WRRB. p. so.

53 Ministerie van Welzijn Volksgezondheid Cultuur (r992). Dat hustert nauu. Samenvatting wan de notitie Theiszorg in de jaren negentig. Rijswijk: wvc. p. 25.

54 Gezondheidsraad (1991). Advies thuiszorg voor patienten met kanker. 's Gravenhage: GR. p. 60.

55 Ziekenfondsraad (1985). Advies Terminale Thwiszorg. Amstelveen: ZFR. p. Io. 
s6 Ministerie van Welzijn, Volksgezondheid Cultuıт (1983). Nota Eerstelijnszorg. Leidschendam: wvc. p. 44.

57 Ziekenfondsraad (1985). Advies Terminale Thuiszorg. Amstelveen: ZFR. p. 4.

58 Narionale Raad voor de Volksgezondheid (1991). Advies ondersteuning mantelzorg. Zoetermeer: NRV. p. 38.

59 zie ook: Achrerberg, T. van (1997). Continuity of Care and client satisfaction in the community. A study of professional and non-professional care for the chronically ill. Maastricht: Unigraphic.

60 Ministerie van Volksgezondheid Welzijn en Sport (1997). Thuiszorg en zorg thuis, kansen voor de toekomst. Rijswijk: vws. p. 5 .

6r Ziekenfondsraad (1985). Advies Terminale Thuiszorg. Amstelveen: ZFR. p. II.

62 Ziekenfondsraad (1985). Advies Terminale Thuiszorg. Amstelveen: ZFR. p. II.

63 Ministerie van Volksgezondheid Welzijn en Sport (1997). Thuiszorg en zorg thuis, kansen voor de toekomst. Rijswijk: vws. p. I6.

64 zie ook: Been, M. de, M. Morée \& H. van de Velde (1996). Professionele Zorg en Mantelzorg: Ondersteuning en samenwerking. Den Haag/Leiden: PCP Zuid-Holland/ Wetenschapswinkel Leiden.

65 zie bijvoorbeeld ook: Bos, G.A.M. van den (1989). Zorgen van en voor chronisch zieken. Utrecht: Bohn, Scheltema en Holkema.

66 zie ook: Pool, A. (1995). Autonomie, afhankelijkheid en langdurige zorgverlening. Utrecht: Lemma.

67 zie: Philipsen, H. (1977). Beweging in de relatic tussen vraag en aanbod in de thuiszorg. In: Philipsen, H. (1988). Gezondheidszarg als project en bejegening. Waarden ten aanzien van ziekte, gezondheid en samenleving. Maastricht: Rijksuniversiteir Limburg. p. 184 .

68 zie ook: Pool, A. (1995). Autonomie, afhankelijkheid en langdurige zorgverlening. Utrecht: Lemma. Pool spreekt over een botsing van een rationaliteitsperspectief van de professionals met een waardenperspectief van patiënten en verzorgers.

69 zie: Abel, E.K. (1990). Family Care of the Frail Elderly. In: Abel, E.K. \& K. Nelson (ed) Circles of Care: Work and Identity in Women's Live. Albany/u.s.A.: Stat. University of New York Press. p. 65-92.

70 zie: Been, M. de, M. Morée \& H. van de Velde (1996). Professionele Zorg en Mantelzorg: Ondersteuning en samemwerking. Den Haag/Leiden: PC.P Zuid-Holland/ Werenschapswinkel Leiden.

Duijnstee, M.S.H. \& M.M. Govaert (1994). De dubbelrol van mantelzorgers. Leeftijd, 30-33.

Nolan, M.R \& G. Grant (i989). Addressing the needs of informal carers a neglected area of nursing pracrice. Journal of Advanced Nursing, 950-96r.

7l uit: Been, M. de, M. Morée \& H. van de Velde (1996). Professionele Zorg en Mantelzorg: Ondersteuning en samenwerking. Den Haag/Leiden: PCP Zuid-Holland/ Wetenschapswinkel Leiden.

72 uit: Been, M. de, M. Morée \& H. van de Velde (1996). Professionele Zorg en Mantelzorg: Ondersteuning en samenwerking. Den Haag/Leiden: PCP Zuid-Holland Wetenschapswinkel Leiden. 
73 zie ook: Manschor, H. (1994). Kwestbare autonomie: Over afhankelijkheid en onafhankelijkheid in de ethiek van de zorg. In: Manschor, H. \& M. Verkerk (I994) Ethiek van de zorg. Een discussie. Amsterdam: Boom. p. 98.

\section{Noten bij hoofdstuk $s$}

I Griffiths, R. (1988). Community care-Agenda for action. A report to the Secretary of State for Social Services. (The Griffiths Report). London Engeland: Her Majesty's Stationary Office.

2 zie ook: Verbiest, A. (1999). Zaken zijn zaken. Taal en kwaliteit van beleid. 's-Gravenhage: Ministerie van Sociale zaken en Werkgelegenheid.

3 Nationale Raad voor de Volksgezondheid (1991). Advies ondersteuning mantelzorg. Zoetermeer: NRV. p. 27 .

4 zie ook: Nederlandse Gezinsraad/sDG (1996). Mantelzorg moet mogen. Den Haag: NGR.

5 zie bijyoorbeeld: Nugent, L.S. (1988). The social support requirements of family caregivers of terminal cancer patients. The Canadian Journal of Nursing Research, $45-58$.

Robinson, B. \& M. Thurnher (1979). Taking Care of Aged Parents: A Fannily Cycle Transition. The Gerontologist, 586-593.

Schene, A. (1986). Thuis bezorgd. Een literatuuronderzoek naar het verschijnsel 'burden on the family'. Utrecht: NCGV.

Schott-Baer, D. (1993). Dependent care, caregiver burden, and self-care agency of spouse caregivers. Cancer Nurs, 230-236.

Schure, L. M. (1995). Partners van cva patiënten. Een onderzoek naar de gevolgen van een cerebrovasculair accident voor de partner van cen patiënt. Groningen: Regenboog.

6 Ministerie van Volksgezondheid Welzijn en Sport (1997). Thuiszorg en zorg thuis, kansen voor de toekomst. Rijswijk: vws.

7 Nationale Raad voor de Volksgezondheid (r99I). Advies ondersteuning mantelzorg. Zoetermeer: NRV. P. 12.

8 zie bijvoorbeeld: Hendriks, E. (1998). De belasting gewogen. De ontwikkeling van een indicatieinstrument om de belasting bij mantelzorgers te bepalen. Tilburg: Steunpunt Mantelzorg Midden Brabant.

9 Kuyper, M. B. (1993). Op de achtergrond. Een onderzoek naar de prablemen van partners van patiënten met een chronische ziekte. Amsterdam: Thesis Publishers.

to zie ook: Kuyper, M. B. (i993). Op de achtergrond. Een onderzoek naar de problemen van partners van patiënten met een chronische ziekte. Amsterdam: Thesis Publishers.

II In hoofdstuk 2 heb ik erop gewezen dar de verzorger in beleid twee gezichien krijgt namelijk als ware ze werknemer (cq. partner) en als ware ze pariënt. Het werknemersperspectief is te vergeliiken met her aanspreken als burger.

12 zie ook: Mol, A. (1997). Klant, burger, zieke. Het goede in drie talen. In: Verkerk. M. (red) Denken over zorg. Concepten en praktijken. Utrecht: Elsevier: de Tijdstroom. p. 139-15I. 
13 Een voorbeeld van een cursus verzorgers te steunen: Steege, G. ter., A. van Servellen (1993). De zorg de baas! Een leergang voor so+ vrouwen die de zorg hebben voor bun partner of voor hun auders. Utrecht Nmw/NBvP.

14 zie ook: Dünstee M.S.H. (1994). Thuis in familiezory. Bunnik: vvr. (oratie) p. Io. Duijnstee, M.S.H. \& M.M. Govaert (1994). De dubbelrol van mantelzorgers. Leeftijd, $30-33$.

Kuhiman G.J., H.S. Wilson, S.A. Hutchinson \& M. Wallhagen (1991). Alzheimer Disease and family Caregiving: Critical Synthesis of the Literature and Research Agenda. Nursing Research, 331-337.

Is zie: Janssen, T., C. Ramakers \& T. Miltenburg (1993). Ervaringen van budgetcliënten. Nijmegen: Instituut voor Toegepaste Sociale Wetenschappen. hoofdstuk 6.

I6 uit: Reijen, M. van (I995). Filosoferen over emoties. Baarn: Nelissen. p. 20.

17 Het voorbeeld betreft:

Landelijke Organisatie Thuisverzorgers (1999). Zorg je voor een ander? Zorg dan ook goed voor jezelf? Bunnik: Lor.

Andere folders mer soortgelijke strekking bijvoorbeeld:

GGD Eindhoven (1998). Gids voor mantelzorgers. Eindhoven: GGD.

GGD Eindhoven/Project Mantelzorg Verlicht (1998). Als u voor een ander zorgt. Eindhoven: GGD.

Landelijke Organisatie Thuisverzorgers (1999). Onder worden en zorgen voor uw partner: Informatie voor 50-phussers die zorgen voor een ander. Bunnik: LOT.

Landelijke Organisatie Thuisverzorgers (1999). Mantelzorgers hebben steun nodig. Bunnik: LOT.

I8 Landelijke Organisatie Thuisverzorgers (1999). Zorg je voor een ander? Zorg dan ook goed voor jezelf? Bunnik: LOT.

19 De in beleid gehanteerde definirie van professionaliseren is een gangbare. Definities die meer bij het perspektief van verzorgers aansluiten zijn te vinden bij: James, $N$. (1992). Care $=$ organisarion + physical labour + emocional labour. Sociology of Health and Illness, 488-509.

Graham, H. (1983). Caring: A labour of love. In: J. Finch \& D. Groves (red). $A$ Labour of Love. London: Roudledge \& Kegan Paul. p. 13-30.

Simonen, L. (1990). Contradictions of the Welfare State, Women and Caring. Tampere: University of Tampere.

20 zie: Jager, H. de., A.L. Mok (1983). Grondbeginselen der sociologie. Gezichtspunten en begrippen. Leiden/Antwerpen: Srenfert Kroese. p. 405.

2r zie voor soortgelijke kritick in andere setrings ook:

Benschop, Y. (1996). De mantel der gelijkhesd. Gender in organisaties. Assen: Van Gorcum.

Gremmen, I. (1995). Ethiek in de gezinsverzorging. Gender en de macht van zorg. Utrecht: Jan van Arkel.

Keizer, M. (1997). De dokter spreckt. Professionaliteit, gender en vitsluiting in medische specialismen. Delft: Eburon.

Smits M.J. (1995). De paradox in de professionalisering. Over zorg en techniek in de verpleging. Gezondheid, 278-289. 
Waerness, K. (1987). 'On the rationality of caring'. In: A.S. Showstack. Sassoon (ed) Women and the state. The shifting boundaries of public and private. London: Hutchinson Education.

22 vergelijk: Swaan, A. de (1990). Zorg en de Staat: Welzijn, onderwijs en gezondheidszorg in Europa en de Verenigde Staten in de nieuwe tijd. Amsterdam: Bert Bakker. p. 250.

23 Abel, E.K. (1990). Family Care of the Frail Elderly. In: Abel, E.K. \& K. Nelson (ed) Circles of Care: Work and Identity in Women's Live. Albany/U.S.A.: Stat. University of New York Press. p. 76.

24 Houtepen, R. (1995). De pijn van uw partner. Tijdschrift voor Gezondheid en Politiek, $13 / 2$, p. I4.

25 zie: Clarke, J. \& J. Newman (1997). The Managerial State. London/ Thousand Oaks/ New Dehli: Sage Publicarions.

26 zie bijvoorbeeld: Clarke, J. \& J. Newman (1997). The Managerial State. London/ Thousand Oaks/New Dehli: Sage Publications.

Los, T. (1997). Bureaucratisering, managementisme en ondergang van her beroep gezinsverzorgster. Amsterdams Sociologisch Tijdschrifi. 709-733.

Politr, C. (1993). Managerialisme and the Public Services. Cuts or Cultural Change in the 19gos? Oxford: Blackwell.

27 Argumenten ontleend aan: Rooyen, M. van (1998). Bij Riaggs komt managementisme nier voor. Tijdschrijft voor de Sociale Sector, 8-12.

28 zie ook: Brandsen, T. (1998). De manager als moderne held. Tijdschrift voor de Sociale Sector; 4-7.

Clarke, J. \& J. Newman (1997). The Managerial State. London/ Thousand Oaks/New Dehli: Sage Publicarions.

29 zie: Clarke. J. \& J. Newman (1997). The Managerial State. London/ Thousand Oaks/ New Dehli: Sage Publications.

30 Stone, D.A. (1997). The Docror as Businessman: The Changing Politics of a Cultural. Icon. Journal of Health Politics, Policy and Law; p. 544.

31 zie voor een kritische bespreking van het werk in de thuiszorg onder invloed van het managmentisme bijvoorbeeld:

Colijn, K. (1999). De stalinistische thuistorg. Cliënt 146513. Vrij Nederland 9 januari, 19.

Los, T. (1997). Bureaucratisering, managementisme en ondergang van het beroep gezinsverzorgster. Amsterdams Sociologisch Tijdschrift, 709-733.

32 zie ook: Evers, A., M. Pijl \& C. Ungerson (eds) (1994). Payments for care, a comparative overview. Avebury: Alderschor.

33 zie bijvoorbeeld: Ministerie van Volksgezondheid Welzijn en Sport (1997). Thuiszorg en zorg thuis, kansen voor de toekomst. Rijswijk: vws. p. 21.

Ministerie van Volksgezondheid Welzijn en Sport (1997) Thuiszorg en zorg thuis, kansen woor de toekomst Rijswijk: vws. p. $2 \mathrm{I}$

34 vergelijk: Mans, I. (1998). Zin der Zotheid. Prometheus Bakker. 


\section{Bronnen}

\section{Bijlage I: Geanalyseerde Beleidsdocumenten}

Breed Indicatie Overleg (1997). Modelprotocol geintergreerde indicatiestelling voor het terrein van wonen, welzijn en zorg. vNG: Den Haag.

Emancipatieraad (1993). Advies vrouwenmantel è mannetrouw in de thuiszorg. Den Haag: ER.

Gezondheidsraad (1991). Advies thuiszorg voor patiènten met kanker. 's-Gravenhage: GR.

Ministerie van Volksgezondheid en Milieuhygiëne (1974). Structuurnota Gezondheidszorg. 's-Gravenhage: Staatsuitgeverij.

Ministerie van Welzijn Volksgezondheid Cultuur (1983). Nota Volksgezondheid bij beperkte middelen. Leidschendam: wvc.

Ministerie van Welzijn, Volksgezondheid Cultuur (1983). Nota Eerstelijnszorg. Leidschendam: wvc.

Ministerie van Welzijn, Volksgezondheid en Cultuur. Interdepartementale werkgroep vergrijzingsproblemariek wvc. (1986). Kosten van vergrijzing voor wvc. Leidschendam: wrvc.

Ministerie van Welzijn, Volksgezondheid en Cultuur (1986). Nota Zorg voor Ouderen. Leidschendam: $w v c$

Ministerie van Welzijn, Volksgezondheid en Cultuur (1988). Verandering Verzekerd. Leidschendam/Rijswijk: wrc

Ministcrie van Welzijn, Volksgezondheid en Cultuur. Rapport van de heroverwegingsgroep (1990). Van samenwerken naar samengaan: gezinszorg en kruiswerk naar een geintrgreerd aanbod in de thuiszorg. Rijswijk: wvc.

Ministerie van Welzijn Volksgezondheid Cultuur (1992). Dat luistert nauw. Samenvatting van de notitie Thuiszorg in de jaren negentig. Rijswijk: wrvc.

Ministerie van Volksgezondheid Welzijn en Sport (1995). Stimuleringsprogramma thuiszorgtechnologie projectresultaten 1991-1994. Groningen: KITzZ.

Ministerie van Volksgezondheid Welzijn en Sport (1997). Thuiszorg en zorg thuis, kansen voor de toekomst. Rijswijk: vws.

Ministerie van Volksgezondheid Welzijn en Sport (1998). Voortgang Indicatiestelling. PBO/ PI/vP/98020. Rijswijk: vws.

Nationale Commissie Chronisch Zicken (1996). Advies Mantelzorg voor chronisch zieken. Zoetermeer: NCCZ.

Nationale Riad voor de Volksgezondheid (1985). Advies kwaliteit, organisatic on financicring thuiszorg. Zoetermecr: NRv.

Nationale Raad voor de Volksgezondheid (1985). Athies thuisverpleging. Zoetermeer: NRV. Nationale Raad voor de Volksgezondheid (1987). Zorguerlening en structuur van de eerste lijn. Zocturncer: NRv. 
Nationale: Raad voor de Volksgezondheid (1989). Discussienota Thuiszorg. Zoetermeer. NRV.

Nacionale Raad voor de Volksgezondheid (1989). Discussienota substiturie in de gezondheidszorg. Zoetermeer: NRV.

Nationale Raad voor de Volksgezondheid (1991). Advies ondersteuning mantelzorg. Zoetermeer: NRV.

Nationale: Raad voor de Volksgezondheid/College voor Ziekenhuisvoorzieningen (1994). Indicatiestelling en zorg op maat. Zoetermeer: NRV.

Nederlandse Gezinsrad/sDg (1996). Mantelzorg moet mogen. Den Haag: NGR.

Tweede Kamer (1973-1974). Structuurnota Gezondheidszorg. "s-Gravenhage: Staatsuitgeverij.

Tweede Kamer (1986) Nota Zorg voor Ouderen. 's-Gravenhage: Staarsuitgeverij.

Tweede Kamer (1991-1992). Thuiszorg in de jaren negentig. Notitie over de toekomstige ontwikkelingen en stimulering van de Thuiszorg. 's-Gravenhage: Staatsuitgeverij.

Tweede Kamer (1992-1993). Beleidsprogramma Emancipatie: 'Met het oog op 1995:'. 's-Gra. venhage: Staatsuitgeverij.

Tweede Kamer (1994-1995). Gezond en wel. Het kader van het volksgezondheidsbeleid 1995-1998. 's-Gravenhage: Staatsuirgeverij.

Werenschappelijke Raad voor her Regeringsbeleid (1993). De toekomst van de thuiszorg: 's-Gravenhage: WRRB.

Ziekenfondsraad (1985). Advies Terminale Thuiszorg. Amstelveen: ZFR.

Ziekenfondsraad (199r). Advies invoering intensieve thuiszorg Amstelveen: ZFR.

\section{Bijlage 2: Geanalyseerde Wetenschappelijke Artikelen}

Abel, E.K. (1990). Informal Care for the Disabled Elderly. A Critiquie of Recent Literature. Research on Aging; 139-157.

Abel, E.K. (1990). Family Care of the Frail Elderly. In: Abel, E.K. \& K. Nelson (ed) Circles of Care: Work and Identity in Women's Live. Albany/u.s.A. Stat. University of New York Press.

Abel, E.K. (1990). Daughers caring for Elderly Parents. In: Gubrium J.F. \& A. Sankar (eds) The home care experience. Ethnography and Policy. Newbury Park/London/New Dehli: Sage.

Abel, E.K. \& M.K. Nelson (1990). Circles of Care: An Introductory Essay. In: Abel, E.K. \& K. Nelson (ed) Circles of Care: Work and Identity in Women's Live. Albanyiu.s.A: Stat. University of New York Press.

Albert, S.M. (1990). The Dependent Elderly, Home Health Care, and Startegies of Household Adaptation. In: Gubrium J.F. \& A. Sankar (eds) The home care experience. Ethnography and Policy. Newbury Park/London/New Dehli: Sage.

Allen S.M. (1994). Gender differences in spousal caregiving and unmer need for care. journal of Gerontology: Social Sciences, 187-195.

Archbold, P.G., B.J. Stewart, M.R. Greenlick. \& T. Harvath (r990). Muruality and Prepard-. ness as Predictors of Caregiver Role Strain. Research in Nursing \& Health, 375-384. 
Ballie, V., J.S. Norbeck \& L-E. A. Barnes (1988). Stress, Social Suppor, and Psychological Distress of Family Caregivers of the Elderly. Nursing Research, 217-222.

Barusch, A.S. (1988). Problems and Coping Strategies of Elderly Spouse Caregivers. The Gerontologist, 677-685.

Berry, G.L., S.H. Zarit \& V.X. Rabatin (r991). Caregiver Activity on Respite and Nonrespite Days: A Comparison of Two Service Approaches. The Gerontologist, 830-835.

Blank, J.J., L. Clark \& A.J. Longman et al. (1989). Perceived home care needs of cancer patients and their caregivers. Cancer Nursing, $78-84$.

Blom, M.M. \& M.S.H. Duijnstee (1993). De patiënt achter de patiënt. Patiënt Care, $53-6 \mathrm{r}$.

Bloom, J.R. (1982). Social support, accomodation to stress and adjustment tot breast cancer. Social Science \& Medicine, 1329-1338.

Bloom, J.R. (1982). Social support systems and cancer; a conceptual view. In: Cohen J., J.W. Cullen \& L.R. Martin (eds) Psychosocial aspects of cancer: New York: Raven Press.

Bos, G.A.M. van den (1989). Zorgen wan en voor chronisch zieken. Utrecht: Bohn, Scheltema en Holkema.

Braun, H. (1983). Verwandschaftliche Hilfe für ältere Menschen. Eine explorative Untersuchung des Handlungsfeldes weiblicher Helfer. Zeitschrift für Gerontologie, 210-215.

Brody, E.M. (1981) "Women in the middle" and Family Help to Older People'. The Gerontologist, $471-480$.

Brody, E.M. (1990). Women in the middle; their parent-care years. New York: Springer.

Buijssen, H. (1991). De wijkverpleegkundige en de centrale verzorger. Methodische aanpak. Tijdschrift voor Ziekenverpleging, 183-186.

Buijssen, H. (1991). De wijkverpleegkundige en de centrale verzorger. Andere vormen van hulp. Tijdschrift voor Ziekenverpleging, 234-237.

Bull, M.J. (1990). Factors Influencing Family Caregivers Burden and Health. Western Journal of Nursing Research, 758-776.

Cantor, M.H. (1983). Strain Among Caregivers: A Study of Experience in the United Stares. The Gerontologist, 597-604.

Cantor, M.H. \& B. Hirshorn (1988). Intergenerational Transfers Within the Family Context-Motivating Factors and Their Implications for Caregiving. Women o. Health: The Journal of Women's Health Care, 39-51.

Carey, PJ., M.T. Oberst, M.A. McCubbin, S.H. Hughes (r991). Appraisal and caregiving burden in family members caring for patients receiving chemotherapy. Oncol Nurs Forum, $134 \mathrm{I}-\mathrm{I} 348$.

Caralan-Fernandez., J.G., O. Pons-Sureda, A. Recober-Martinez, A. Avellà-Mestre, J,M. Carbonero-Marberti, E. Beniro-Oliver \& I. Garau-Llinás (1991). Dying of cancer The place of death and family circumstances. Medical Care, 841-852.

Cawley, M.M. \& E.K. Gerdts (1988). Establishing a Cancer Caregivers Program. Cancer Nursing, 267-273.

Clipp E.C. \& L.K. George (1993). Dementia and Cancer: a comparison of spouse caregivers. The Gerontologist. 534-541. 
Close, P. E. Burkey, A. Kazak, P. Danz \& B. Lange (1995). A propsective, controlled evaluation of home chemotherapy for children with cancer: Pediatrics, 896-900.

Conkling, V.K. (1989). Continuity of Care for Cancer Patients and Families. Cancer, 290-294.

Cooge, M. \& C.G. Varricchio (1981). A pilot investigarion of home health care needs of cancer patients and their families. Oncological Nursing Forum, 24-28.

Courtens, A.M. (1993). Kenmerken van zorg en kwaliteit van leven bij patiënten met kanker. Maastricht: UPM.

Cuijpers, P. (1994). Ondersteuning van mantelzorgers van chronisch zicken. In: Duijnstee, M.S.H., W.J.M.J. Cuijpers, M.J. Humbert \& A.W.L. van den Dungen. Mantelzorg voor mensen met een chronische ziekte. Een literatuurstudie naar de rol wan mantelzorg voor mensen met cen chronische ziekte op basis van Nederlandse studies gepubliceerd in de periode 1980-1993. Zoetermeer: NCCZ.

Daal H.J. van (1990). Vrijwilligerswerk en informele bulp in Nederland. Fen inventarisatie van onbetaald werk buiten het eigen huishouden, in het bijzonder op bet gebied van de bulpverlening. 's-Gravenhage: Nederlands Instituut voor Maarschappelijk Werk Onderzoek.

Dautzenberg, M.G.H., J.P.M. Diederiks, H. Philipsen \& F.C.J. Stevens (1996). Vrouwen van een middengeneratie en informele zorg voor ouderen. Tijdschrift voor Geroniologie en Geriatrie, I41-I50.

Dautzenberg, M.G.H., J.P.M. Diederiks, H. Philipsen \& F.C.J. Srevens (1998). Women of a Middle Generarion and Parent Care. J. of Aging and Human Development, 241-262.

Dellasega, C. (1990). The relarion berween caregiving and employment. A study of stress in employed and unemployed caregiver of elderly persons. Aaobn journal, 154-159.

Dowler, J.M., D.A. Jordon-Simpson \& O. Adems (1992). Gender inequalities in CareGiving in Canada. Health Reports, 125-136.

Duijnstee, M. (1993). De belasting van familieleden van dementerenden. Nijkerk: Intro.

Duijnstee, M.S.H., W.J.M.J. Cuijpers, M.J. Humbert \& A.W.L. van den Dungen (1994). Mantelzorg voor mensen met een chronische ziekte. Zoetermeer: NCcz.

Dunkel- Schetter C., C. Wortman (1982). The interpersonal dynamics of cancer in social relationships and their impacts on patient. In: Friedman H.S., M.R. Dimatreo (eds) Interpersonals Issues in Health Care. New York: Academic Press.

Dunkel-Schetter C. (1984). Social support and cancer: findings based on patient interviews and their implications. Journal Soc, Issues, 77-98.

Ell Ko., R.H. Nishimoto, J.E. Mantell \& M.B. Hamovitch (1988). Psychological adaption to cancer: a comparison among patients, spouses, and non-spouses. Family Systems Medicin, 335-348.

Francell, C.G., V.S. Conn, \& D.P. Gray (1988). Families' Perceptions of Burden of Care for Chronic Mentally IIl Relarives. Hospital and Community Psychiatry 1296-1300.

Grobe, M.E., D.M. Ilstrup \& D.L. Ahmann (1981). Skills needed bij family members to maintain the care of an advanced cancer patient. Cancer Nursing, 371-375. 
Gwyther, L.P. \& M.A. Matteson (1983). Care for the caregivers. Journal of Gerontological' Nursing, 93-95.

Haes, J.C.J.M. de (1988). Kwaliteit van leven van kankerpatiënten. Amsterdam/Lisse: Swets \& Zeitlinger.

Harrison, D.S. \& K.D. Cole (r9gr). Family Dynamics and Caregiver burden in Home Health Care. Clinics in Geriatric Medicine, $817-829$.

Hatringa Verschure, J.C.M. (1972). Ontwikkelingen van zorgcriteria voor herstructurering van de gezondheidszorg. Het Ziekenhuis, s00-s05.

Hatringa Verschure, J.C.M. (I979). Mantelzorg. Mealisch Contact, 139-142.

Hartinga Verschure, J.C.M. (1981). Het verschijnsel Zorg; Een inleiding tot de zorgkunie. Lochem: De Tijdstroom.

Hatringa Verschure, J.C.M. (1987). Zelfredzame ouderen. Lochem/Gent: De Tijdstroom.

Hatringa Verschure, J.C.M. (1989). Mantelzorg rond ouderen. Geriatric-informatorium, 1020-1-1020-17.

Higginson, I., A. Wade \& M. McCarthy (1990). Palliative care: views of patienes and their families. British Medical Journab 277-280.

Hileman, J.W. \& N.R. Lackey (1990). Self-Identified Needs of Patiens With Cancer at Home and Their Home Caregivers: A Descriptive Srudy. Oncological Nursing Forum, 907-913.

Hileman, J.W., N.R. Lackey \& R.S. Hassanein (r992). Identifying the needs of Home Caregivers of Parient with Cancer. Oncology Nursing Forum, 77'I-777.

Hinds, C. (1985). The needs of families who care for parients with cancer at home: are we meeting them? Journal of Advanced Nursing, $575-581$.

Hinds, C. (1992). Suffering: a relatively unexplored phenomenon among family caregivers of non-institutionalized patients with cancer. Journal of Advanied Nursing, 918-925

Janssen, T. (1985). Thuiszorg bij oudere mensen. Nijmegen: Sociologisch Instituut ku.

Janssen, T. (1988). De betekenis van de familie voor de centrale verzorg(st)er van hulpbehoevende oudere mensen. Tijdschrift voor Gerontologie en Geriatrie, I85-194.

Janssen, T. (1988). Zorg om mantelzorg. Verzorg(st)er van de invaliderende oudere mens. Tijdschrift woor Ziekenverpieging, 169-174.

Janssen, T., C. Ramakers \& T. Miltenburg (1993). Enaringen van budgetcliënten. Nijmegen: Instituut voor Toegepaste Sociale Wetenschappen.

Jayabos, S., V. Escobedo, O. Tugal, A. Nahaczewski, P. Donohue, V. Fuenres, G. Devereau $\&$ S. Sunkara (1991). Home chemotherapy for children with cancer. Canier, 574-579.

Jensen, S. \& B.A. Given (1991). Fatigue affecting family caregivers of cancer patients. Can-. cer $N u r s, 18 \mathrm{I}-187$.

Jones, R.V.H., J. Hansford \& J. Fiske (1993). Dearh from cancer at home: the carers' perspecrive. Br.Med J, 249-25I.

Killeen. M. (1990). The InHuence of Stress and Coping on Family Caregivers' Perceptions: of Health. Int. Jowrnal Aging and Human Dewrlopment, 197-211.

Kirby, D. (1987). Support for the silent suffers. Nursing Tomes, 43-44. 
Knipscheer, C.P.M. (1980). Oude mensen en hun sociale omgeving: een studie van het primair sociaal netwerk. 's-Gravenhage: Vuga-boekerij.

Kurtz, M.E., B. Given, J.C. Kurtz \&. C. W. Given (1994). The interaccion of age, symptoms, and survival status on physical and mental health of patients with cancer and their families. Cancer, $2071-2078$.

Kuyper, M. B. (1993). Op de achtergrond. Een onderzoek naar de problemen van partners van patiënten met een chronische ziekte. Amsterdam: Thesis Publishers.

Laizner A.M., L.M.S. Yosr, F.K. Barg \& R. Mc Corkle (1993). Needs of family caregivers of persons with cancer: a review. Semin Oncol Nurs, Ir4-12O.

Lewandowski, W. \& S.L. Jones (1988). 'The family with cancer' Cancer Nursing, 313-321.

Lewis, J. \& B. Meredith (1988). Daughters who care: daughters caring for mothers at home. London/New York: Routledge.

Lindsey., A.M., J.S. Norbeck V.L. Carrieri \& E. Perry (1981). Social support and Health Care outcomes in postmastectomy women: a review. Cancer Nurs, 377-384.

McCann, J.J. (r988). Long Term Home Care for the Elderly: Perceptions of Nurses, Physicians and Primary Caregivers. QRB, march, 66-74.

McMillan, S.C. (1996). Quality of life of primary caregivers of hospice patients with cancer. Cancer practice, 191-198.

McMillan, S.C. \& M. Mahon (1994). The impact of hospice services on the quality of life of primary caregivers. Oncol. Nurs. Forum, In 89-II9s.

Mohide, E.A., G.W. Torrance, D.L. Streiner, D.M. Pringle \& R. Gilbert (1988). Measuring the well being of family caregivers using the time trade-off rechnique. J. Clinical Epidemiology, 475-482.

Mor, V., S.M. Allen, K. Siegel \& P. Houts (1992). Determinants of Need and Unmet among Cancer Patients Reviding at Home. Health Service Research, 337-360.

Nolan, M.R \& G. Grant (1989). Addressing the needs of informal carers a neglected area of nursing practice. Journal of Advanced Nursing, 950-96r.

Nordlicht, S. (1982). The Family of the Cancer Patient NY State / Med, 1845-1846.

Nugent, L.S. (1988). The social support requirements of family caregivers of terminal cancer patients. The Canadian Journal of Nursing Research, $45-58$.

Oberst, M.T., K.A. Gass \& S.E. Ward (1989). Caregiving demands and appraisal of stress among farnily caregivers. Cancer Nursing, 209-215.

Opie, A. (1994). The instability of the Caring Body: Gender and Caregivers of Confused Older People. Qualitative Health Research, 3I-50.

Parkes C.M. (1985). The dying parient. terminal care: home, hospital or hospice? Lancet, iis5-157.

Peteer J.R. (1982). A closer view at the concept of support: some applications to the care of patient with cancer. Gen Hosp Psychiatry, 19-23.

Plaats, J.J. van de (i988). De ondersteuning van de verzorgers thuis van chronische pariënten. Metamedica, 414-425. 
Rair D. \& M.S. Lederberg (1989). The farnily of the cancer patient. In: J.C. Holland, J.H. Rowland (eds) Handbook of pyychooncology: psychological care of patients with cancer. New York: Oxford Universiry Press.

Ros, W.J.G. (1990). Sociale steun bij kankerpatiënten. Amsterdam: Thesis Publishers.

Schene, A. (1986). Thuis bezorgd. Een literatuuronderzoek naar het verschijnsel burden on the family. Utrecht: NCGV.

Schort-Baer, D. (1993). Dependent care, caregiver burden, and self-care agency of spouse caregivers. Cancer Nurs, 230-236.

Stephens M.A.P., M.M. Franks, \& A.L. Townsed (1994). Stress and reward in women's multiple roles: the case of women in the middle. Psychology and Aging, 45-52.

Stetz, K.M. (1987). Caregiving Demands During Advances: Cancer- the Spouse Needs. Cancer Nursing. 260-268.

Sykes, N.P. S.E. Pearson \& S. Chell (1992). Quality of care of the terminally ill: the carer's perspective. Palliative Medicine, 227-236.

Tjadens, F.L.J. \& Cl. Woldringh (1989). Informele zorg in Nederland: zelfzorgproblemen, behoefte aan zorg en praktisch-instrumentele onderlinge hulp. Nijmegen: Instituut voor Toegepaste Sociale Wetenschappen.

Twigg, J. \& K. Arkin (1994). Carers Perceived. Policy and Practice in Informal Care. Buckingham-Philadelphia: Open University Press.

Townsend. J., A.O. Frank, D. Fermont, S. Dyer, O. Karran. A. Walgrove \& M. Piper (1990). Terminal cancer care and patients preference for place of dearh: a prospective study. $B r$ Med J, 415-417.

Ungerson, C. (1987). Policy is personal; sex, gender and informal care. London: Tavistock Publications LTD

Vernooy-Dassen, M.J.F.J. (1992). Dementie en thuiszorg: een onderzoek naar determinanten van het. competentiegevod van centrale verzorgers en het effect van professionele interventie. Lisse: Swers \& Zeitlinger.

Wingate A.L. \& N.R. Lackey (1989). A description of the needs of noninstitutionalized cancer patients and their primary caregivers. Cancer Nurs, 216-225.

Woods, N.F., Lewis F.M. \& E.S. Ellison (1989). Living with cancer: family experiences. Cancer Nursing; 28-33.

Zarit, S.H., K.E. Reever, \& J. Bach Peterson (1980). Relarives of the impaired elderly: Correlates of feelings of burden. The Gerontologist, 269-655.

Zarit, S.H., P.A. Todd, \& J.M. Zarit (1986). Subjective burden of husbands and wives as caregivers: A longitudinal study. The Gerontologist, 260-266. 
Bijlage 3: Overzicht Geïterviewde Verzorgers

Persoonsgegevens geïnterviewde verzorgers:

$\begin{array}{lllll}\text { casusno: } & \mathrm{m} / \mathrm{v} & \text { geb. jaar } & \text { relatie } & \text { duur (thuis)-zorg } \\ \mathrm{Im} & v & 1960 & \text { partner } & 1 \text { jaar } \\ 2 \mathrm{~m} & \mathrm{~m} & 1959 & \text { partner } & 1,5 \mathrm{jaar} \\ 3 \mathrm{~m} & v+\mathrm{m} & 1938+1935 & \text { schoonzus + broer } & 3 \mathrm{mnd} \\ 4 \mathrm{~m} & v & 1944 & \text { dochter } & 5 \mathrm{mnd} \\ 5 \mathrm{~m} & v & 1963 & \text { kleindochter } & 6 \mathrm{mnd} \\ 6 \mathrm{~m} & \mathrm{~m} & 1958 & \text { partner } & 4 \mathrm{mnd} \\ 7 \mathrm{~m} & v & 1942 & \text { dochter } & 5 \mathrm{mnd} \\ 8 \mathrm{~m} & v & 1936 & \text { partner } & 7 \mathrm{mnd} \\ 9 \mathrm{~m} & v & 1944 & \text { partner } & 2 \mathrm{mnd} \\ 10 \mathrm{~m} & v & 1945 & \text { partner } & 7 \mathrm{mnd} \\ 11 \mathrm{~m} & v+v & 1939+1962 & \text { partner + dochter } & 7 \mathrm{mnd} \\ 12 \mathrm{~m} & v & 1936 & \text { partner } & 2 \mathrm{mnd} \\ 13 \mathrm{~m} & v & 1958 & \text { dochter } & 5 \mathrm{mnd} \\ 14 \mathrm{~m} & v+v & 1945+1940 & \text { dochter + dochter } & 7 \mathrm{mnd} \\ 15 \mathrm{~m} & v & 1944 & \text { partner } & 4 \mathrm{mnd} \\ 16 \mathrm{~m} & v & 1947 & \text { dochter } & 6 \mathrm{mnd} \\ 17 \mathrm{~m} & v & 1926 & \text { schoonzus } & 4 \mathrm{mnd} \\ 18 \mathrm{~m} & v & 1937 & \text { partner } & 5,5 \mathrm{mnd} \\ 19 \mathrm{~m} & \mathrm{~m} & 1923 & \text { partner } & 4 \mathrm{mnd} \\ 20 \mathrm{~m} & v & 1960 & \text { partner } & 9 \mathrm{mnd}\end{array}$


Persoonsgegevens verzorgers die vragenlijsten ingevuld hebben:

$\begin{array}{lllll}\text { casusno: } & \mathrm{m} / \mathrm{v} & \text { geb.jaar } & \text { relatie } & \text { duur thuiszorg } \\ \text { Iv } & \mathrm{v} & 1934 & \text { partner } & 8 \mathrm{mnd} \\ 2 \mathrm{v} & \mathrm{v} & 1953 & \text { dochter } & 3,5 \text { jaar } \\ 3 \mathrm{v} & \mathrm{v} & 1960 & \text { vriendin } & 4 \mathrm{mnd} \\ 4 \mathrm{v} & \mathrm{v} & 1941 & \text { dochter } & 5 \mathrm{mnd} \\ 5 \mathrm{v} & \mathrm{v} & 1929 & \text { partner } & 6 \mathrm{mnd} \\ 6 \mathrm{v} & \mathrm{v} & 1941 & \text { dochter } & 5 \mathrm{mnd} \\ 7 \mathrm{v} & \mathrm{v} & 1965 & \text { dochter } & 7 \mathrm{mnd} \\ 8 \mathrm{v} & \mathrm{v} & 1971 & \text { partner } & 7 \mathrm{mnd} \\ 9 \mathrm{v} & \mathrm{v} & 1936 & \text { dochter } & 1 \text { jaar } \\ 10 \mathrm{v} & \mathrm{v} & 1950 & \text { dochter } & 4 \mathrm{mnd} \\ 11 \mathrm{v} & \mathrm{v} & 1953 & \text { dochter } & 2 \mathrm{mnd} \\ 12 \mathrm{v} & \mathrm{m} & 1938 & \text { partner } & 2 \mathrm{mnd} \\ 13 \mathrm{v} & \mathrm{v} & 1946 & \text { dochter } & 7 \mathrm{weken} \\ 14 \mathrm{v} & \mathrm{m} & 1933 & \text { partner } & 5 \text { dagen } \\ 15 \mathrm{v} & \mathrm{v} & 1935 & \text { zus } & 9 \mathrm{mnd} \\ 16 \mathrm{v} & \mathrm{v} & 1944 & \text { partner } & 6 \mathrm{mnd} \\ 17 \mathrm{v} & \mathrm{v} & 1943 & \text { dochter } & 14 \mathrm{mnd} \\ 18 \mathrm{v} & \mathrm{v} & 1951 & \text { dochter } & 2 \mathrm{mnd} \\ 19 \mathrm{v} & \mathrm{v} & 1942 & \text { partner } & 2 \mathrm{mnd} \\ 20 \mathrm{v} & \mathrm{v} & 1962 & \text { partner } & 8 \mathrm{mnd} \\ 21 \mathrm{v} & \mathrm{v} & ? ! & \text { partner } & 3 \mathrm{wkn} \\ 22 \mathrm{v} & \mathrm{v} & 1948 & \text { partner } & 5 \mathrm{mnd} \\ 23 \mathrm{v} & \mathrm{v} & 1929 & \text { partner } & 7 \mathrm{mnd} \\ 24 \mathrm{v} & \mathrm{v} & 1960 & \text { dochter } & 11 \mathrm{mnd} \\ 25 \mathrm{v} & \mathrm{v} & 1954 & \text { dochter } & 2 \mathrm{mnd} \\ 26 \mathrm{v} & \mathrm{v} & 1941 & \text { partner } & 1 \mathrm{mnd} \\ 27 \mathrm{v} & \mathrm{m} & 1941 & \text { zoon } & 2 \mathrm{mnd} \\ 28 \mathrm{v} & \mathrm{v} & 1952 & \text { dochter } & 6 \mathrm{mnd} \\ 29 \mathrm{v} & \mathrm{v} & 1960 & \text { partner } & 1 \text { jaar } \\ 30 \mathrm{v} & \mathrm{v} & 1958 & \text { dochter } & 2 \mathrm{weken} \\ & & & & \end{array}$


Topic-list en vragenlijst

- Hoe heeft u de zorg voor uw naaste ervaren?

-Wie heeft tot thuiszorg besloten?

-Welke rol speelde u in dit beslissingproces?

- Welke professionele verzorgers waren er bij de zorg betrokken?

- Hoe was uw verhouding tot de professionele verzorgers?

- Zou u weer tot thuiszorg overgaan? Zo ja waarom wel, zo nee waarom niet?

- Heeft u nog opmerkingen/suggesties etc. over het geven van informele zorg thuis aan patienten met kanker? 


\section{Literatuur}

Abel, E.K. (1990). Informal Care for the Disabied Elderly. A Critique of Recent Literature. Research on Aging, 139-157.

Abel, E.K. (1990). Family Care of the Frail Elderly. In: Abel, E.K. \& K. Nelson (ed) Circles of Care: Work and Identity in Women's Live. Albany/U.S.A.: Stat. University of New York Press.

Abel, E.K. (1990). Daughers caring for Elderly Parents. In: Gubrium J.F. \& A. Sankar (eds) The home care experience. Ethnography and Policy. Newbury Park/London/New Dehli: Sage.

Abel, E.K. \& M.K. Nelson (1990). Circles of Care: An Introductory Essay. In: Abel, E.K. \& K. Nelson (ed) Circles of Care: Work and Identity in Women's Live. Albany/U.S.A.: Star. Universicy of New York Press.

Abma, T.A. (1991). Drie kernproblemen van beleidsevaluatie doordacht vanuir de naturalisrische benadering. Beleid en Maatschappij, 226-236.

Abma, T.A. (1992). Beleidsevaluatie volgens het politiek-sociale leermodel. Vernieuwend onderzoek naar Sociale Vernieuwing in Rotterdam. Management en Organisatie, 423-440.

Abma, T.A. (1993). Voorbij de technocratische oriëntate in beleidsevaluatie. Beleid en Maatschappij, 244-254.

Abma, T.A. (1996). Responsief evalueren. Discoursen controversen en allianties in het postmoderne. Delft: Eburon.

Achterberg, T. van (1997). Contimity of Care and client satisfaction in the community. A study of professional and non-professional care for the chronically ill. Maastricht: Unigraphic.

Akker, P.A.M. van den., M.H.L. van Tits \& N.M. Kok (r994). Leven met de dood. Over terminale patiënten en terminale zorg in Nederland. Houten/Zaventem: Bohn Stafleu Van Loghum.

Alberr, S.M. (1990). The Dependent Elderly, Home Healch Care, and Srrategies of Household Adaptation. In: Gubrium J.F. \& A. Sankar (eds) The home care experience. Ethnography and Policy. Newbury Park/London/New Dehli: Sage.

Allbrook, D. (1984). Dying of cancer- home, hospice or hospital. Med. J. Aust, i41-144.

Allen S.M. (1994). Gender differences in spousal caregiving and unmet need for care.. Journal of Gerontology: Social Sciences, 187-195:

Archbold, P.G., B.J. Stewart, M.R. Greenlick, T. Harvath (1990). Mutuality and Prepardness as Predictors of Caregiver Role Strain. Research in Nursing of Health, 375-384.

Ariès, Ph. (1990). Met bet oog op morgen, westerse opvattingen over de dood van de Middeleeuwen tot beden. Amsterdam: Wetenschappelijke Uitgeverij.

Ballie, V., J.S. Norbeck \& L-E. A. Barnes (1988). Stress, Social Suppor, and Psychologicall Distress of Family Caregivers of the Elderly. Nursing Research, 217-222. 
Barusch, A.S. (1988). Problems and Coping Strategies of Elderly Spouse Caregivers. The Gerontologist, 677-685.

Been, M. de, M. Morée \& H. van de Velde (1996). Professionele Zorg en Mantelzong: Ondersteuning en samenwerking. Den Haag/Leiden: PCP Zuid-Holland/Wetenschapswinkel Leiden.

Bekker, M. (1995). Werk en kinderen: dubbele belasting of een gezonde combinatie? Tijdschrift voor Vrouwenstudies, 397-413.

Benschop, Y. (1996). De mantel der gelijkheid. Gender in organisaties. Assen: Van Gorcum. Berg, M. \& S.M. van der Lyke (1997). De normativiteir van een infuuspomp. Over zorgpraktijken en technologie. In: M. Verkerk (red) Denken over Zorg. Concepten en praktijken. Utrechr: Elsevier/ de Tijdstroom.

Berry, G.L., S.H. Zarit \& V.X. Rabatin (1991). Caregiver Activity on Respite and Nonrespite Days: A Comparison of Two Service Approaches. The Gerontologist, 830-835.

Blank, J.J., L. Clark \& A.J. Longman et al. (1989). Perceived home care needs of cancer patients and their caregivers. Cancer Nursing, 78-84.

Blom, M.M. \& M.S.H. Duijnstee (1993). De patiënt achter de patiënt. Patiënt Care, 53-6r.

Bloom, J.R. (1982). Social support, accomodation to stress and adjustment tot breast cancer. Social Science of Medicine, 1320-1338.

Bloom, J.R. (1982). Social support systems and cancer; a conceptual view. In: Cohen J., J.W. Cullen \& L.R. Martin (eds) Psychosocial aspects of cancer. New York: Raven Press.

Boer, A.H. de., J.C. Hessing-Wagner, M. Mootz \& I.S. Schoemakers-Salkinoja (r994). Informele zorg: een verkenning van buidige en toekomstige ontwikkelingen. Rijswijk: Sociaal en Cultureel Planbureau.

Bos, G.A.M. van den (1989). Zorgen van en voor chronisch zieken. Utrecht: Bohn, Scheltema en Holkema.

Brandsen, T. (1998). De manager als moderne held. Tijdschrift voor de Sociale Sector, 4-7.

Braun, H. (1983). Verwandschaftliche Hilfe für ältere Menschen. Eine explorative Untersuchung des Handlungsfeldes weiblicher Helfer. Zeitschrift fiir Gerontologie, 210-215.

Breed Indicatie Overleg (1997). Modelprotocol geïntegreerde indicatiestelling voor het terrein van wonen, welzijn en zorg. vNG: Den Haag.

Brody, E.M. (1981). "Women in the middle" and Family Help to Older People'. The' Gerontologist, 471-480.

Brody, E.M. (1990). Women in the middle; their parent-care years. New York: Springer.

Brouns, M. \& M. Zwinkels (1995). Arbeid, zorg en autonomie. In: Brouns, M., M. Verloo \& M. Grunell (red) Vrouwenstudies in de jaren negentig. Een kennismaking vanuit verschillende disciplines. Bussum: Courinho.

Bruijn, J.G.M. de (1991) Omstreden kwaliteit: omtrent vrouwenarbeid en beleid. Amsterdam: vu University Press. (oratie)

Bruijn, J. de (1991). Funcriewaardering en beloning van vrouwenwerk. Tijdschrift voor Vroutvenstudies, 19-31.

Buis, M. (1990). Ondersteuning van mantelzorg Een staalkaart van initiatieven. Utrecht: NIZW. 
Buijssen, H. (1991). De wijkverpleegkundige en de centrale verzorger. Merhodische aanpak. Tijdschrift voor Ziekenverpleging, 183-186.

Buijssen, H. (1991). De wijkverpleegkundige en de centrale verzorger. Anclere vormen van hulp. Tijolschrifi voor Ziekenverpleging, 234-237.

Bull, M.J. (1990). Factors Influencing Family Caregivers Burden and Health. Western Journal of Nursing Research,758-776.

Bull, M.J. (r992). Managing the Transition From Hospital to Home. Qualitative Health Research, 27-4I.

Cantor, M.H. (1983). Strain Among Caregivers: A Study of Experience in the United States. The Gerontologist, 597-604.

Cantor, M.H. \& B. Hirshorn (1988). Intergenerational Transfers Within the Farnily Context-Motivating Factors and Their Implications for Caregiving. Women \& Health: The Journal of Women's Health Care, 39-51.

Carey, P.J., M.T. Oberst, M.A. McCubbin \& S.H. Hughes (1991). Appraisal and caregiving burden in family members caring for patients receiving chemotherapy. Oncol Nurs Forum, 1341-1348.

Catalan-Fernandez., J.G., O. Pons-Sureda, A. Recober-Martinez, A. Avellà-Mestre, J,M. Carbonero-Marberti, E. Benito-Oliver \& I Garau-Llinás (1991). Dying of cancer. The place of death and family circumstances. Medical Care, $84 \mathrm{~T}-852$.

Cawley, M.M., E.K. Gerdts (1988). Establishing a Cancer Caregivers Program. Cancer Nursing, 267-273.

Centraal Bureau voor Statistiek (1990). Overledenen naar doodsoorzaak leefiijd en geslacht. Serie B1 Nederland x988: primaire doodsoorzaken, absolute aantallen gerubriceerd naar plaats van overlijden. Voorburg: CBS.

Clarke, J. \& J. Newman (1997). The Managerial State. London/ Thousand Oaks/New Dehli: Sage Publications.

Clipp E.C. \& L.K. George (1993). Dementia and Cancer: a comparison of spouse caregivers. The Gerontologist, 534-541.

Close, P., E. Burkey, A. Kazak, P. Danz \& B. Lange (1995). A propsective, controlled evaluation of home chemorherapy for children with cancer. Pediatrics, 896-900.

Colijn, K. (1999). De stalinistische thuiszorg. Cliënt 146513 . Vrij Nederland'9 januari, 19.

Conkling. V.K. (1989). Continuity of Care for Cancer Patients and Families. Cancer, 290-294.

Cooge, M. \& C.G. Varricchio (1981). A pilot investigation of home health care needs of cancer patients and their families. Oncological Nursing Forum, 24-28.

Corbin, J. \& A. Strauss (1988). Unending work and care. San Francisco: Jossey-Bass.

Corbin, J.M. \& A. Strauss (1990). Making Arrangements The Key to Home Care. In: Gubrium J.F. \& A. Sankar (eds) The home care experience. Eth́nography and Policy. Newbury Park/London/New Dehli: Sage.

Courrens, A.M. (1993). Kenmerken van zorg en kwaliteit van leven bij patiënten met kanker. Maastricht: UPM.

Cox, S. (1991). Mantelzorg belast en gesteund. Tilburg: Provinciaal Opbouworgaan NoordBrabant. 
Cuijpers, P. (1994). Ondersteuning van mantelzorgers van chronisch zieken. In: Duijnstee, M.S.H., W.J.M.J. Cuijpers, M.J. Humbert \& A.W.L. van den Dungen. Mantelzorg voor mensen met een chronische ziekte. Een literatuurstudie natr de rol van mantelzorg voor mensen met een chronische ziekte op basis van Nederlandse studies gepubliceerd in de periode 1980-1993. Zoetermeer: NCcz.

Daal H.J. van (1990). Vrijwilligerswerk en informele hulp in Nederland. Een inventarisatie van onbetald werk buiten het eigen huishouden, in het bijzonder op het gebied van de hulpuerlening. 's-Gravenhage: Nederlands Instituut voor Maatschappelijk Werk Onderzoek.

Daurzenberg, M.G.H., J.P.M. Diederiks, H. Philipsen \& F.C.J. Stevens (1996). Vrouwen van een middengeneratie en informele zorg voor ouderen. Tijdschrift woor Gerontologie en Geriatrie, 141-150.

Dautzenberg, M.G.H., J.P.M. Diederiks, H. Philipsen \& F.C.J. Stevens (1998). Women of a Middle Generation and Parent Care. J. of Aging and Human Development, 241-262.

Davies, C. (1995). Gender and the professional predicament of nursing. Buckingham/ Philiadelphia: Open University Press.

Dellasega, C. (1990). The relacion berween caregiving and employment. A study of stress in employed and unemployed caregiver of elderly persons. Aaohn joumal, 154-159.

Dowler, J.M., D.A. Jordon-Simpson \& O. Adems (1992). Gender inequalities in CareGiving in Canada. Health Reports, 125-136.

Duijnstec, M. (1993). De belasting van familieleden van dementerenden. Nijkerk: Intro.

Duijnstee M.S.H. (1994). Thuis in familiezorg. Bunnik: LVT. (oratie)

Duijnstee, M.S.H. \& M.M. Govaert (1994). De dubbelrol van mantelzorgers. Leeftijd, 30-33.

Duijnstee, M.S.H., W.J.M.J. Cuijpers, M.J. Humbert \& A.W.L. van den Dungen (1994). Mantelzorg woor mensen met een chronische aiekte. Zoetermeer: NCcz.

Dunkel-Schetter C., C. Wortman (1982). The interpersonal dynamics of cancer in social relationships and their impacts on patient. In: Friedman H.S., M.R. Dimatreo (eds) Interpersonals Issues in Health Care. New York: Academic Press.

Dunkel-Schetter C. (1984). Social support and cancer: findings based on patient interviews and their implications. Joumal Soc. Issues, 77-98.

Eeten, M.J.G. van, M.J.W van Twist \& P.R. Kaanders (1996). Verhalen vertellen. Van een narratieve bestuurskunde naar een posmoderne beweerkunde? Bestuurkunde, 168-185.

Elias, N. (1990). De eenzaamheid van stervenden in onze tijd. Amsterdam: Meulenhoff.

Ell Ko., R.H. Nishimoto, J.E. Mantell \& M.B. Hamovitch (1988). Psychological adaption to cancer: a comparison among patients, spouses, and non-spouses. Frmily Systems Medicin, $335-348$.

Emancipatieraad (r993). Advies vrowwenmantel in mannetrouw in de thuiszorg. Den Haag: ER.

Enarson, E. (1990). Experts and Caregivers: Perspectives on Underground Day Care. In: Abel, E. K. \& K. Nelson (ed) Circles of Care: Work and Identity in Women's Live. Albany/U.S.A.: Stat. University of New York Press. 
Evers, A., M. Pijl \& C. Ungerson (eds) (1994). Payments for care, a comparative overview. Avebury: Alderschor.

Francell, C.G., V.S. Conn \& D.P. Gray (1988). Families' Perceptions of Burden of Care for Chronic Mentally Ill Relarives. Hospital and Community Psychiatry, 1296-1300.

Frankenberg, R. (1992). Your Time or Mine: temporal contradictions of biomedical practice. In: Frankenberg, R. (ed) (1992). Time Healib o Medicine, London: Sage.

Fraser, N. (1989). Unruly Practices: Power, Discourse and Gender in Contemporary Social Theory. Oxford: Polity Press.

Fraser, N. (1991). 'Whar's Critical about Critical Theory: The case of Habermas and Gender'. In: Lyndon Shanley., M. \& C. Pateman (eds). Feminist Interpretations and Political Theory. Cambridge: Polity Press.

Friele, R.D. \& J.J. Kerssens (1995). Techniek in de thuiszorg. Evaluatie van het stimuleringsprogramma thuiszorgtechnologie. Utrecht: Nivel.

Frissen, P.H.A. (1996). De virtuele staat, politiek bestuur, technologie: een postmodern verhaal. Schoonhoven: Academic Service.

Gezondheidsraad (1991). Advies thuiszorg voor patiënten met kanker. 's Gravenhage: GR. GGD Eindhoven (1998). Gids voor mantelzorgers. Eindhoven: GGD.

GGD Eindhoven/Project Mantelzorg Verlicht (1998). Als u voor een ander zorgt. Eindhoven: GGD.

Glaser, B. \& A. Strauss (1965). The Awareness of Dying. Chicago: Aldine.

Guba, E.G. \& Y.S. Lincoln (1987). The countenances of fourth generation evaluation: Description, judgement and negotiation. In: Corday, D.S. \& M.W. Lipsey (ed). Evaluation Studies Review Annual, Newburry Park: Sage Publication.

Goode, D.A. (1990). On understanding without words: Communication between a deafblind child and her parents. Human Studies, 1-37.

Gorter, K.A. (1988). Zorgen voor gehandicapte gezinsleden. Een landelijk onderzoek naar problemen en hulpverlening binnen huishoudens met lichamelijk gehandicapten. Den Haag: Nederlands Instituut voor Maarschappelijk Werkonderzoek.

Goudriaan, G. (1988). Thuiszorg tussen de lijnen. Den Haag: Harmonisatieraad Welzijnsbeleid.

Goudriaan, G., T. Kraan \& N. de Boer (1995). Mantelzorgers stcunen waarom en hoe? Utrecht: Nederlands Instituut voor Zorg en Welzijn.

Graaf, H. van de. \& R. Hoppe (1996). De interpretatie van een beleidstekst. In: Beleid en Politiek. Een inleiding tot de beleidswerenschap en de beleidskunde. Bussum: Coutinha.

Graham, H. (1983). Caring: A labour of love. In: J. Finch \& D. Groves (red). A Labour of Love. London: Roudledge \& Kegan Paul.

Gremmen, I. (1995). Ethick in de gezinsverzorging. Gender en de macht van zorg. Utrecht: Jan van Arkel.

Griffiths, R. (1988). Community care-Agenda for action. A report to the Secretary of State for Social Services. (The Griffiths Report). London Engeland: Her Majesty's Stationary Office.

Grobe, M.E., D.M. Ilstrup \& D.L. Ahmann (1981). Skills needed bij family members to maintain the care of an advanced cancer patient. Cancer Nursing, 371-375. 
Groenedijk, H. (1998). Werken en zorgen: de moeite waard. Een onderzoek naar het welbevinden van buitenshuis werkende moeders. Utrecht: Jan van Arkel.

Groenewegen, P.P., A. Kerkstra \& G.A. Jansen (1993). Wachtlijsten in de thuiszorg. Utrecht: Nivel.

Gwyther, L.P. \& M.A. Matteson (1983). Care for the caregivers. Journal of Gerontological Nursing, 93-95.

Haaren, E. van (1993). Het mantelzorgsysteem: Het echtpaar P. Tijdschrift voor Ziekenverpleging, 23-24.

Haaren, E. van (1993). Het mantelzorgsysteem: Een wankel evenwicht. Tijdschrift voor Ziekenverpleging, $25-28$.

Haes, J.C.J.M. de (1988). Kwaliteit van leven van kankerpatiënten. Amsterdam/Lisse: Swets \& Zeitlinger.

Hagemann-White, C. (1989). Geslacht en Gedrag. In: Sevenhuijsen, S. (red) SocialistischeFeministische Teksten. Baarn: Ambo.

Halsema, L. (1994). Een gender-subtekst van beleid. Een analyse van 'Een werkend perspektief' van de Werenschappelijke Raad voor her Regeringsbeleid. Tijdschrift voor Vrouwenstudies, 212-224.

Harrison, D.S. \& K.D. Cole (1991). Family Dynamics and Caregiver burden in Home Health Care. Clinics in Geriatric Medicine, 817-829.

Hatringa Verschure, J.C.M. (1972). Ontwikkelingen van zorgcriteria voor herstructurering van de gezondheidszorg. Het Ziekenhuis, 500-505.

Hattinga Verschure, J.C.M. (1979). Mantelzorg. Medisch Contact, 139-142.

Hattinga Verschure, J.C.M. (1981). Het verschijnsel Zorg; Een inleiding tot de zorgkunde. Lochem: De Tijdstroom.

Hatringa Verschure, J.C.M. (1987). Zelfredzame ouderen. Lochem/Gent: De Tijdstroom.

Hattinga Verschure, J.C.M. (1989). Mantelzorg rond ouderen. Geriatrie-informatorium, 1020-1-1020-17.

Heinsbroek, N. \& H. van Tilburg (1996). Zorgen voor mantelzorgers. Handreikingen om mantelzorgers te ondersteunen. Utrecht: SDG.

Helmond, T. van (1996). De verhouding mantelzorg-professionele zorg. In: N. Heinsbroek \& H. van Tilburg (1996). Zorgen voor mantelzorgers. Handreikingen om mantelzorgers $t$ ondersteunen. Utrecht: SDG.

Hendriks, E. (1998). De belasting gewogen. De ontwikkeling van een indicatieinstrument om de belasting bij manielzorgers te bepalen. Tilburg: Steunpunt Mantelzorg Midden Brabant.

Hepburn, K.W. \& B.A. Gates (1988). Family Caregivers for Non-Alzheimer's Dementia Patients. Clinics in Geriatric Medicine, 925-940.

Higginson, I., A. Wade \& M. McCarthy (1990). Palliative care: views of patients and their families. Brirish Medical Journal. 277-280.

Hileman. J.W. \& N.R. Lackey (1990). Self-Identified Needs of Patiens With Cancer at Home and Their Home Caregivers: A Descriptive Study. Oncological Nursing Forum, $907-913$.

Hileman, J.W., N.R. Lackey \& R.S. Hassanein (1992). Idenrifying the needs of Home Caregivers of Patient with Cancer. Oncology Nursing Forum, 771-777. 
Hinds, C. (1985). The needs of families who care for patients with cancer at home: are we meeting them? Journal of Advanced Nursing, $575-581$.

Hinds, C. (1992). Suffering: a relatively unexplored phenomenon among family caregivers of non-institutionalized parients with cancer. Journal of Advanced Nursing, 918-925.

Hirschfeld, M. (1983). 'Homecare versus institutionalization: family-caregiving and senile brain disease.' Int. I. Nursing Studies, 23-32.

Hoff, B.W. van 't (1996). Enquete Thuiszorg. Terp Adviesbureau Utrecht: Eck en Wiel.

Hoogerwerf, A. (1984) 'Beleid berust op veronderstellingen: de beleidstheorie'. Acta Politica, 494-53I.

Hoogerwerf. A. (1995). Beleidswetenschap als uitdaging voor vrouwenstudies. Beleidswetenschap, 347-351.

Hoppe, R. (1993). Political Judgment and Policy Cycle: The Case of Ennicity Policy Arguments in the Netherlands. In: Fischer, F. \& J. Forester (eds) The argumentative turn in Policy Analysis and Planning. London: UCL Press.

Horowiz, A. (1985). Family Caregiving to the Frail Elderly. In: Eisdorfer C. (ed) Annual review of gerontology and geriatrics, 194-254.

Houtepen, R. (1995). De pijn van uw partner. Tijdschrift voor Gezondheid en Politiek, 13/2, I4.

IJzerman, M. \& C. Scholren (1998). Wachtlijsten in de thuiszorg. Eerste meting van de Quick Scan onder toegelaten thuiszorginstellingen. Leiden: Research voor Beleid.

Illich, 1. (1975). Het medisch bedriff een bedreiging voor de gezandheid. Baarn: Het Wereldvenster.

Jager, H. de. \& A.L. Mok (1983). Grondbeginselen der sociologie. Gezichtspunten en begrippen. Leiden/Antwerpen: Stenfert Kroese.

James, N. (1992). Care=organisation+ physical labour + emotional labour. Sociology of Health and Illness, 488-509.

Janssen, T. (1985). Thniszorg bij oudere mensen. Nijmegen: Sociologisch Instituut KU.

Janssen, T. (r988). De berekenis van de familie voor de centrale verzorg(st)er van hulpbehoevende oudere mensen. Tijdschrift voor Gerontologie en Geriatrie, 185 -191.

Janssen, T. (1988). Zorg om mantelzorg. Verzorg(st)er van de invaliderende oudere mens. Tijdschrift voor Ziekenverpleging. 169-174.

Janssen, T., C. Ramakers \& T. Milrenburg (1993). Ervaringen van budgetcliënten. Nijmegen: Instituut voor Toegepaste Sociale Wetenschappen.

Jayabos, S., V. Escobedo, O. Tugal, A. Nahaczewski, P. Donohue, V. Fuentes, G. Devereau \& S. Sunkara (1991). Home chemorherapy for children with cancer. Cancer, 574-579. Jensen, S. \& B.A. Given (1991). Farigue affecring farnily caregivers of cancer patients. Cancer Nurs, $18 \mathrm{I}-187$.

Jones, R.V.H., J. Hansford \& J. Fiske (1993). Death from cancer at home: the carers' perspecrive. Br: Med J, 249-251.

Keizer, M. (1997). De dokter spreekt. Professionaliteit, gender en uitsluiting in medische specialismen. Delft: Eburon.

Kempen, G.I.J.M. (1990). Thuiszorg voor ouderen. Groningen: sryx Publications. 
Kensen, S. (1999). Sturen op variatie. Sociale Vernieuwing en de deense variant als bronnen van inspiratie. 's-Gravenhage: vNG Uitgeverij.

Keulartz, J. (1987). Van bestraffing naar behandeling. Een inleiding in de sociologie van de hulpverlening. Amsterdam/Meppel: Boom.

Keuzenkamp, S. \& M. Schaapman (1995). Vrouwenstudies als uitdaging voor beleidswetenschappers. Beleidswetenschap, 342-346.

Killeen, M. (ig9o). The Influence of Stress and Coping on Family Caregivers' Perceptions: of Health. Int. Journal Aging and Human Development, 197-211.

Kirby, D. (1987). Support for the silent suffers. Nursing Times, 43-44.

Knipscheer, C.P.M. (1980). Oude mensen en hun sociale omgeving: een studie van het primair sociaal netwerk. 's-Gravenhage: Vuga-bockerij.

Knyn, T. (1992). Balanceren op ongelijke leggers: veranderingen in zorg en arbeidsverhoudingen tussen de seksen. Tijdschrift voor Vrouwenstudies, 497-509.

Kronjee, G.J. \& M.G. Spiering-Wolter (1993). De toekomst van de Thuiszorg. Een inventarisatie van bepalende factoren en problemen. Den Haag: Wetenschappelijke Raad voor het Regeringsbeleid.

Kuhiman G.J., H.S. Wilson, S.A. Hurchinson \& M. Wallhagen (1991). Alzheimer Disease and family Caregiving: Critical Synthesis of the Literature and Research Agenda. Nursing Research, 331-337.

Kurtz, M.E., B. Given, J.C. Kurtz \& C.W. Given (r994). The interaction of age, symptoms, and survival status on physical and mental health of patients with cancer and their families. Cancer; $2071-2078$.

Kuyper, M. B. (1993). Op de achtergrond. Een onderzoek naar de problemen van partners van patiënten met een chronische ziekte. Amsterdam: Thesis Publishers.

Kwaliteits Instituut voor Toegepaste Thuizorgvernieuwing/Ministerie van Volksgezondheid, Welzijn en Sport (1995). Stimuleringsprogramma Thuiszorgtechnologie, projectresultaten 199r-1994. Groningen: krrzz/Ministerie van vws.

Kwekkeboom, M.H. (1990). Het licht onder de Korenmaat. Informele zorgverlening in Nederland. 's-Gravenhage: vugA.

Laizner A.M., L.M.S. Yost, F.K. Barg \& R. Mc Corkle (r993). Needs of family caregivers of persons with cancer: a review. Semin Oncol Nurs, Ir4-120.

Landelijke Organisatie Thuisverzorgers (1999). Zorg je voor een ander? Zorg dan ook goed voor jezelf? Bunnik: Lor.

Landelijke Organisatie Thuisverzorgers (1999). Ouder worden en zorgen voor uw partner. Informatie voor 50-plussers die zorgen voor een ander. Bunnik: LOT.

Landelijke Organisarie Thuisverzorgers (1999). Mantelzorgers hebben steun nodig. Bunnik: Lot.

Lewandowski, W. \& S.L. Jones (1988). 'The family with cancer' Cancer Nursing; 313-32r.

Lewis, J. \& B. Meredith (1988). Daughters who care: daughters caring for mothers at home. London/New York: Routledge.

Lincoln, Y.S. \& E.G. Guba (r985). Naturalistic inquire. Newbury Park/London/New Delhi: Sage Publicarions.

Lindsey., A.M., J.S. Norbeck V.L. Carrieri \& E. Perry (198r). Social support and Health Care outcomes in postmastectomy women: a review. Cancer Nur3, 377-384. 
Los, T. (1997). Bureaucratisering, managementisme en ondergang van het beroep gezinsverzorgster. Amsterdams Sociologisch Tijdschrifi, 709-733.

Londen, J. van (1987). Thuiszorg. Huiswerk voor allen vóór het jaar 2000. Utrecht: Rijksuniversiteit Utrechr. (oratie)

Lyke, S. van der (1995). Mantelzorg maakt patiënten. Van ideaal naar pragmatisme. Tijdschrift voor Gezondheid en Politiek, 13/2 7-10.

Lyke, S.M. van der, P.H. Toren (i996). Een kwestie van vertrouwen. Procesevaluatie van indicatiesystemen in de thuiszorg. Verpleegkunde, 23-30.

Maarse, J.A.M. (i990). Beleidsanalyse in de gezondheidszorg. In: Maarse, J.A.M. \& 1.M. Mur-Veeman (red) Beleid en beheer in de gezondheidszorg. Problemen, structuren, processen en effecten. Assen/Maastricht: Van Gorcum.

Mans, I. (1998). Zin der Zorheid. Prometheus Bakker.

Manschor, H. (1994). Kwestbare auronomie: Over afhankelijkheid en onafhankelijkheid in de ethiek van de zorg. In: Manschot, H. \& M. Verkerk (1994) Ethiek van de zorg. Een discussie. Amsterdam: Boom.

Mc Cann, J.J. (1988). Long Term Home Care for the Elderly: Perceptions of Nurses, Physicians and Primary Caregivers. QRB, march, 66-74.

Mc Cann, K. \& E. Wadsworth (1992). The role of informal carers in supporting gay men who have HIV relared illness: what do they do and what are their needs? Aids Care, 25-34.

McMillan, S.C. (1996). Quality of life of primary caregivers of hospice patients with cancer. Cancer practice, 191-198.

McMillan, S.C. \& M. Mahon (1994) The impact of haspice services on the quality of life of primary caregivers. Oncol. Nurs. Forum, n89-1195.

Meyer, M. (1996). In telst gevat. Inleiding tot een kritiek nan representatic. Amsterdam: University Press.

Miller, B. (1990). Gender Differences in Spouse Management of the Caregiver Role. In: Abel, E.K. \& K. Nelson (ed) Circles of Care: Work and Identity in Women's Live. Albany/U.S.A.: Stat. University of New York Press.

Miltenburg, T. (1990). Intensieve Thuiszorg. Ervaringen uit de proefregio's. Nijmegen: Instituut voor Toegepaste Sociale Wetenschappen.

Ministerie van Volksgezondheid en Milieuhygiene (1974). Structuurnota Gezondheidszorg. 's Gravenhage: Staarsuitgeverij

Ministerie van Welzijn Volksgezondheid Cultuur (1983). Nota Volkesgezondheid bij beperkte middelen. Leidschendam: wrc.

Ministerie van Welzijn, Volksgezondheid Cultuur (1983). Nota Eerstelijnszorg. Leidschendam: wre.

Ministerie van Welzijn, Volksgezondheid en Cultuur (1986). Nota Zorg voor Ouderen. Leidschendam: wrc.

Ministerie van Welzijn, Volksgezondheid en Cultuur (1988). Verandering Verzekerd. Leidschendam/Rijswijk: wvc.

Ministerie van Welzijin, Volksgezondheid en Cultuur. Interdepartementale werkgroep vergrijzingsproblematiek wvc (1986). Kosten van vergrijzing voor WVC. Leidschendam: wryc. 
Ministerie van Welzijn, Volksgezondheid en Cultuur/Heroverwegingsgroep (1990). Van samenwerken naar samengaan: gezinszorg en kruiswerk naar cen geïntegreerd aanbod in de thuiszorg. Rijswijk: wvc.

Ministerie van Welzijn Volksgezondheid Cultuur (1992). Dat luistert nauw. Samenvatting van de notitie Thuiszorg in de jaren negentig. Rijswijk: wvc.

Ministerie van Volksgezondheid Welzijn en Sporr (1995). Stimuleringsprogramma thuiszorgtechnologie projectresultaten 199r-1994. Groningen: kitzz.

Ministerie van Volksgezondheid Welzijn en Sporr (i997). Thuiszorg en zorg thuis, kansen voor de toekomst. Rijswijk: vws.

Ministerie van Volksgezondheid, Welzijn en Sport (1998). Voortgang Indicatiestelling. PBO/ $P I / v P / g 8020$. Rijswijk: vws.

Mohide, E.A., G.W. Torrance, D.L. Streiner, D.M. Pringle \& R. Gilbert (1988). Measuring the well being of family caregivers using the time trade-off technique. J. Clinical Epidemiology $475-482$.

Mol, A. (r997). Klant, burger, zieke. Her goede in drie ralen. In: Verkerk. M. (red) Denken over zorg. Concepten en praktijken. Utrecht: Elsevier: de Tijdstroom.

Mor, V., S.M. Allen, K. Siegel \& P. Houts (1992). Determinants of Need and Unmet among Cancer Patients Reviding ar Home. Health Service Research, 337-360.

Morée, M. (1992). 'Mijn kinderen hebben er niets van gemerkt'. Buitenshuis werkende moeders tussen 1950 en nu. Utrecht: Jan van Arkel.

Moréc, M. (1996). De januskop van de mantelzorg. Tijdschrift voor gezondheid en politiek, $14 / 4,13-16$.

Nationale Raad voor de Volksgezondheid (1985). Advies thuisverpleging. Zoctermeer: NRV. Nationale Raad voor de Volksgezondheid (1985). Advies kwaliteit, organisatie en financiering thuiszorg. Zoetermeer: NRV.

Nationale Raad voor de Volksgezondheid (1987). Zorgverlening en structur van de eerste lijn. Zoetermeer: NRV.

Nationale Raad voor de Volksgezondheid (1989). Discussienota Thuiszorg. Zoetermeer: NRV.

Nationale Raad voor de Volksgezondheid (1989). Discussienota substitutie in de gezondheidszorg. Zoetermeer: NRV.

Nationale Raad voor de Volksgezondheid (1991), Advies ondersteuning mantelzorg. Zoetermeer: NRV.

Nationale Commissie Chronisch Zieken (1996). Advies Mantelzorg voor chronisch zieken. Zoerermeer: NCCZ.

Nationale Raad voor de Volksgezondheid/College voor Ziekenhuisvoorzieningen (1994). Indicatiestelling en zorg op maat. Zoetermeer: NRV.

Nederlandse Gezinsraad/sDG (1996). Mantelzorg moet mogen. Den Haag: NGR.

Nolan, M.R \& G. Grant (1989). Addressing the needs of informal carers a neglected area of nursing practice. Journal of Advanced Nursing, 950-96i.

Nordlicht, S. (1982). The Family of the Cancer Patient NY State J Med, 1845-1846.

Nugent, L.S. (1988). The social support requirements of family caregivers of terminal cancer parients. The Canadian Journal of Nursing Research, 45-58. 
Oberst, M.T., K.A. Gass \& S.E. Ward (1989). Caregiving demands and appraisal of stress among family caregivers. Cancer Nursing, 209-215.

Opie, A. (1994). The instability of the Caring Body: Gender and Caregivers of Confused Older People. Qualitative Health Research, 31-50.

Oudhof, P (1996). De betaalbaarheid van de thuiszorg. Een pleidooi voor herbezinning. In: Dokrer, H., P. van Lieshout \& B. Schadé (1996). Zorg aan huis. Een stand van zaken. Utrecht: De Tijdstroom.

Oudshoorn, N.E.J. (1996). Genderscripts in technologie. Noodlot of uitdaging. Enschede: Universiteit Twente. (oratie)

Parkes C.M. (1985). The dying patient. terminal care: home, hospital or hospice? Lancet, iI55-I57.

Peräkylä, A. (1997). Reliability and validity in research based on transcripts. In: Silverman, D. (ed) Qualitative Research. Theory, Method and Practice. London: Sage: Publications.

Peteet J.R. (1982:). A closer view at the concept of support: some applications to the care of patient with cancer. Gen Hosp Psychiatry 19-23.

Philipsen, H. (1977). Beweging in de relatie tussen vraag en aanbod in de thuiszorg. In: Philipsen, H. (1988). Gezondheidszorg als project en bejegening. Waarden ten aanzien van ziekte, gezondheid en samenleving. Maastricht: Rijksuniversiteit Limburg.

Philipsen, H. (1985). Rationaliteit en ons oordeel over de verdwijnende pariënt. Gezondheid en Samenleving, I42-152.

Plaats, J.J. van de (1988). De ondersteuning van de verzorgers thuis van chronische patiënten. Metamedica, 414-425.

Ploeg, I. van der (199I). Verdwenen lichamen. Voortplantingstechnicken, vrouwenlichamen en vaders in beleidsrapporten over in vitro fertilisatie en kunstmatige inseminarie. Tijdschrift voor Vrouwenstudies, 329-347.

Politt, C. (1993). Managerialisme and the Public Services. Cuts or Cultural Change in the rggos? Oxford: Blackwell.

Pool, A. (1995). Auronomie, afhankelijkheid en langdurige zorgverlening. Utrecht: Lemma.

Potting, M. (1994). Sekse, ouderdom en wetenschap. De rol van sekse in de sociale gerontologie. Maastricht: Datawyse.

Potring, M. (1997). Van je familie. Tijdschrifi voor Gezondheid en Politiek, 2, 23-24.

Rait D. \& M.S. Lederberg (1989). The family of the cancer patient. In: J.C. Holland, J.H. Rowland (eds) Handbook of psychooncology: psychological care of patient. with cancer. New York: Oxford Universicy Press.

Reijen, M. van (1995). Filosoferen over emoties. Baarn: Nelissen.

Robinson, B. \& M. Thumher (1979). Taking Care of Aged Parents: A Family Cycle Transition. The Gerontologist, 586-593.

Roe, E. (1994). Namative Policy Analysis. Durhum London: Duke University Press.

Rooyen, M. van (1998). Bij Riaggs kome managementisme niet voor. Tijdschrijf voor de Sociale Sector, 8-12.

Ros, W.J.G. (1990). Sociale steun bij kankerpatiënten. Amsterdam: Thesis Publishers. 
Rubinstein, R.L. (1990). Culture and Disorder in the Home Care Experience. The Home as a Sickroom. Gubrium J.F. \& A. Sankar (eds) The bome care experience. Ethnography and Policy. Newbury Park/London/New Dehli: Sage.

Schene, A. (1986). Thuis bezorgd. Een literatuuronderzoek naar het verschijnsel burden on the family. Utrecht: NCGv.

Schott-Baer, D. (1993). Dependent care, caregiver burden, and self-care agency of spouse caregivers. Cancer Nurs, 230-236.

Schure, L. M. (1995). Partners van cva patiënten. Een onderzoek naar de gevolgen van een cerebrovasculair accident voor de partner van een patiënt. Groningen: Regenboog.

Scott, J. (1986). 'Gender: A Useful Category of Historical Analysis.' American Historical Review, 1053-1075.

Silverman, D. (2000). Validity and reliability. In: D. Silverman. Doing Qualitative Research. Practical Handbook. London: Sage Publicarion.

Simonen, L. (1990). Contradictions of the Welfare State, Women and Caring. Tampere: University of Tampere.

Smits M.J. (1995). De paradox in de professionalisering. Over zorg en techniek in de verpleging. Gezondheid, 278-289.

Steege, G. ter:, A. van Servellen (1993). De zorg de baas! Een leergang voor $50+$ vrouwen die de zorg bebben voor hun partner of voor hun ouders. Utrecht NIzw/NBvP.

Srephens M.A.P., M.M. Franks, \& A.L. Townsed (r994). Stress and reward in women's multiple roles: the case of women in the middle. Psychology and Aging, 45-52.

Stetz, K.M. (1987). Caregiving Demands During Advances Cancer- the Spouse Needs. Cancer Nursing, 260-268.

Stone, D.A. (1997). The Doctor as Businessman: The Changing Politics of a Cultural Icon. Journal of Health Politics, Policy and Law, 533-557.

Stuurgroep Toekomstscenario's Gezondheidszorg/Scenariocommissie Kanker (1987). Kanker in Nederland. Utrecht: Bohn, Scheltema en Holkema.

Stuurgroep Toekomstscenario's Gezondheidszorg (1992). Toekomstscenario's voor eerstelijn en thuiszorg. Houten/Zaventem: Bohn, Stafleu van Loghem.

Stuurgroep Toekomst Scenario's Gezondheidszorg (1992). Onderen in het jaar 2005: gezondheid en zorg: geactualiseerde scenario's over gezondheid en vergrijzing rogo-2005. Houten/ Zaventem: Bohn, Srafleu van Loghem.

Sykes, N.P., S.E. Pearson \& S. Chell (1992). Quality of care of the terminally ill: the carer's perspective. Palliative Medicine, 227-236.

Swaan, A. de (1990). Zorg en de Staat. Welzijn, onderwijs en gezondheidszorg in Europa en de Verenigde Staten in de nieuwe tijd. Amsterdam: Bert Bakker.

Tijssen, I.M.J.G. \& E. Elsinga (1990). Evaluatie-onderzoek op het terrein van de gezondheidszorg. In: Maarse, J.A.M. \& I.M. Mur-Veeman (red) Beleid en beheer in de gezondheidszorg. Problemen, structuren, processen en effecten. Assen/Maastricht: Van Gorcum.

Timmermans, J. (red) (1997). Rapportage Ouderen 1996. Rijswijk: scP. 
Tjadens, F.L.J. \& Cl. Woldringh (1989). Informele zorg in Nederland: zelfzorgproblemen, behoefte aan zorg en praktisch-instrumentele onderlinge hulp. Nijmegen: Instituut voor Toegepaste Sociale Werenschappen.

Townsend. J., A.O. Frank, D. Fermont, S. Dyer, O. Karran. A. Walgrove \& M. Piper (1990). Terminal cancer care and patients' preference for place of death: a prospective study. $\mathrm{Br} \mathrm{Med} \mathrm{J,} 415-417$.

Tronto J.C. (1993). Moral Boundaries. A political argument for an ethics of care. New York/ London: Routledge.

Tweede Kamer (1973-1974). Structuurnota Gezondheidszorg. 's-Gravenhage: Staatsuitgeverij.

Tweede Kamer (1986) Nota Zorg voor Ouderen. 's-Gravenhage: Staatsuitgeverij.

Tweede Kamer (1991-1992). Thuiszorg in de jaren negentig. Notitie oner de toekomstige ontwikkelingen en stimulering van de Thuiszorg. 's-Gravenhage: Staarsuitgeverij.

Tweede Kamer (1992-1993). Beleidsprogramma Emancipatie: 'Met het oog op 19g5"s-Gravenhage: Staatsuitgeverij.

Tweede Kamer (1994-1995). Gezond en wel. Het kader van het volksgezondheidsbeleid 1995-1098. "s-Gravenhage: Staatsuitgeverij.

Twigg, J. \& K. Atkin (1994). Carers Perceived. Policy and Practice in Informal Care. Buckingham-Philadelphia: Open University Press.

Twist, M. van (1994). Verbale Vernieuwing. Aantekeningen over de kunst van bestuurskunde. 's-Gravenhage: vuGA.

Ungerson, C. (1987). Policy is personal; sex, gender and informal care. London: Tavistock Publications LTD.

Verbiest, A. (1999). Zaken zijn zaken. Taal en kwaliteit van beleid. 's-Gravenhage: Ministerie van Sociale zaken en Werkgelegenheid.

Verkerk, M. (1994). Zorg of contract: een andere ethiek. In: Manschot, H. \& M. Verkerk (1994). Ethiek van de zorg. Een discussie. Amsterdam: Boom.

Vernooy-Dassen, M.J.F.J. (1992). Dementic en thuiszorg: een onderzoek naar determinanten van het competentiegevoel van centrale verzorgers en het effect van professionele interventie. Lisse: Swers \& Zeirlinger.

Visser, A. (1996). Informarisering. In: Visser, A. \& H. van Lieshour (red). Welzijnswerkers: en computers -meer dan tekstverwerken-. Bussum: Dick Coutinho.

Vulto, M. \& M. Morée (1996). Thuisverzorging als professie. Een combinatie van hand, hoofd en hart. Utrecht: De Tijdstroom.

Waerness, K. (1987). 'On the rationality of caring'. In: A.S. Showstack Sassoon (ed) Women and the state. The shifting boundaries of public and private. London: Hutchinson Education.

Wagenaar, H. (1995). 'Urgent stories; morality and narrative in public administration.' Adminstration theory of praxis, 92-104.

Wetenschappelijke Raad voor het Regeringsbeleid (1993). De toekomst van de thuiszorg. 's-Gravenhage: WRRB. 
Wingate A.L. \& N.R. Lackey (1989). A description of the needs of noninstitutionalized cancer patients and their primary caregivers. Cancer Nurs, 216-225.

Witteveen, P.O., A.J.H. van Boxtel \& G. Blijham (1996). Eindverslag project verzorgingstechnologie thuis voor patiënten met kanker of ernstige infectie. Utrecht: Academische Ziekenhuis Utrecht.

Woods, N.F., Lewis F.M. \& E.S. Ellison (1989). Living with cancer: family experiences. Cancer Nursing, 28-33.

Yanow, D. (1998). Public policies as identity stories: American race-ethnic discourse. In: Abma, T. (1998). Telling Tales: On narrative and evaluation. Aduanced in Program Evaluation: JaI Press.

Zarit, S.H., K.E. Reever, \& J. Bach Peterson (1980). Relatives of the impaired elderly: Correlates of feelings of burden. The Gerontologist, 269-655.

Zarit, S.H., P.A. Todd, \& J.M. Zarir (1986). Subjecrive burden of husbands and wives as caregivers: A longitudinal study. The Gerontologist, 260-266.

Ziekenfondsraad (1985). Advies Terminale Thuiszorg. Amstelveen: ZFR.

Ziekenfondsraad (1991). Advies invoering intensieve thuiszorg. Amstelveen: ZFR.

Zola, I.K. (1973). De medische macht. De invloed van de gezondheidszorg op de maatschappij. Amsterdam: Boom Meppel. 


\section{Samenvatting}

Vanaf de jaren tachrig stimuleert de overheid extramurale zorg. Dat wil zeggen dat ze thuiszorg en informele zorg ten koste van intramurale zorg en professionele zorg propageert. In dit proefschrift wordt nagegaan hoe de overheid de inzet van informele zorg bevordert. Hoe interveniëren beleidsmakers in de privésfeer? Hoe beïnvloeden ze bestaande verwantschapsrelaties? Het proefschrift beschrijft de relatie tussen overheidsbeleid en informele zorg.

De analyse geeft vooral inzicht in het normarieve karakter van het informele zorgbeleid en legt de impliciete veronderstellingen of conventies van dit beleid bloot. Vanwege het sekse-specifieke karakter van informele zorg is daarbij speciaal gelet op gender-conventies. Van welke vanzelfsprekendheden, die samenhangen met het denken over mannen en vrouwen cq. mannelijkheid en vrouwelijkheid, maken beleidsmakers gebruik? Anders gezegd: Welke gender-conventies produceren beleidsmakers in het informele zorgbeleid? Het doel van dit onderzoek is deze conventies inzichtelijk te maken en na te gaan welke betekenis het gebruik van gender-conventies in het informele-zorgbeleid heeft voor de praktijk van de informele zorg.

Om dit normatieve karakter van het informele zorgbeleid te onderzoeken zijn beleidsteksten over informele zorg vergeleken met teksten van wetenschappers en verzorgers zelf. Beleidsmakers gebruiken immers wetenschappelijke kennis om hun beleid te staven. Daarbij willen ze problemen van burgers cq. verzorgers oplossen. Ze trachten in ieder geval antwoord te geven op de door verzorgers aangereikte kwesties en bij hen aan te sluiten. Wetenschappers en verzorgers zijn dus belangrijke peilers voor dit beleid.

Door een vergelijking van deze zogenoemde vertogen geeft de studie inzicht in de verwevenheid van her beleidsvertoog met de andere vertogen. Het laat zien in hoeverre beleid conventies van wetenschappers en burgers incorporeert. De vergelijking zorgt ook voor afstand, verbazing en reflectie. Het geeft inzicht in de vraag waarin de vertogen van elkaar verschillen. Ik ga er dus enerzijds vanuit dat de taal van beleidsmakers is voorgevormd; beleidsteksten dragen conventies van andere raalgebruikers. Anderzijds geeft diezelfde taal beleidsmakers ook ruimte voor het doorbreken van stereotiepe conventies die bijvoorbeeld huidige man/vrouw cq. gender beelden bevestigen. Dus de gevonden verschillen in de vertogen bieden beleidsmakers een alternatief vocabulaire.

Gezien de vraagstelling begeeft dit onderzoek zich op het snijvlak van beleidswetenschap en vrouwenstudies. De theoretische concepten zijn aan deze disci- 
plines ontleend. Beleid is niet opgevat als iets van beleidsmakers alleen, maar wordt beschouwd als een (calig) resultaat van de maatschappelijke, sociale omgeving waarin het vorm krijgt. Dir geldt evenzeer voor gender. Wat als vrouwelijk of mannelijk wordt beschouwd is geen vaststaand gegeven, maar wordt steeds in onze taal ge(her)definieerd. Deze uitgangspunten, de gebruikte concepten en merhode van onderzoek beschrijf ik in hoofdstuk $\mathrm{r}$. Tevens beschrijf ik in dit hoofdstuk de argumenten die beleidsmakers gebruiken om informele zorg te bevorderen en de manier waarop het de publieke overheid lukt invloed uit te oefenen op zorg in de privésfeer.

In hoofdstuk 2 wordt het beleid met wetenschappelijke teksten vergeleken. Ik geef antwoord op de vraag hoe conventies over informele zorg in het beleid zijn verschoven en onderscheid, op basis van die conventies, drie perioden in het informele zorgbeleid. Werden verzorgers in de eerste periode van het beleid sekseneutraal beschreven en vooral gedefinieerd als een waardevol subsysteem voor het torale gezondheidszorgsysteem, in de tweede periode komt het sekse-specifieke karakter van verzorgers meer op de voorgrond te staan. Verzorgers zijn vrouwen. Dan vragen beleidsmakers zich af of het zorgsysteem, gezien de toenemende arbeidsparticipatie van vrouwen, nog wel op de inzet van verzorgers mag rekenen. Men vreest dat her aantal verzorgenden te klein zal zijn. In de derde periode, tot slot, verschuift de aandacht van beleidsmakers van een kwantitatief tekort aan verzorgsters naar een tekort aan individuele draagkracht. Dus: in het informele zorgbeleid zijn conventies over verzorgers op twee manieren verschoven. Stond eerst het collecrief systeemdenken op de voorgrond, dit heeft plaats gemaakt voor het denken vanuit de verzorger als vrouwelijk individu. Werd eerst de sterkte of kracht van het informeel zorgsysteem benadrukt, dit maakt langzaam plaats voor de ontoereikendheid of zwakte van de verzorgster. De zwakke verzorgster domineert. Dit hoofdstuk toont een gender-conventie in de beschrijving van informele verzoigers.

In hoofdstuk 3 vergelijk ik beleidsteksten met verhalen van verzorgers. In dit hoofdstuk geef ik antwoord op de vraag hoe beleidsmakers de verhouding tussen patiënt en verzorger thuis beschrijven. De patiënt is volgens beleidsmakers een rationeel subject die kiest thuis te zijn. Volgens verzorgers is er weinig sprake van een keuze, maar is voor patiënten de externe dwang en morele druk groot om thuis te blijven of naar huis te gaan. Tegenover de rationele patiënt die beleidsmakers veronderstellen, zetten verzorgers een van anderen en gewoonte afhankelijke patiënt. Waarom willen patiënten thuis zijn? Volgens beleidsmakers winnen zij thuis aan autonomie. Hoewel verzorgers dat niet ontkennen, wijzen ze wel steevast op het verlies van hun autonomie. Zij moeten immers thuis zijn, geven veel van hun tijd aan de zieke en worden soms door professionals gecorrigeerd. 
Daarmee leveren zij aan vrijheid in. (Mannelijke) waarden die beleidsmakers voor patiènten erg belangrijk achten zoals keuzevrijheid en autonomie, spelen in beleid voor verzorgsters een veel kleinere rol. Dit hoofdstuk toont een gender-conventie of asymmetrie tussen de beschrijving van patiënt en verzorger.

In hoofdstuk 4 vergelijk ik conventies in beleid wederom met conventies van verzorgers. In dit hoofdstuk geef ik antwoord op de vraag hoe beleidsmakers de relatie tussen professionele en informele verzorgers thuis beschrijven. De professional handelt volgens beleidsmakers op basis van universele kennis en expertise en houdt er een rationeel-methodische werkwijze op na. Dit is geleerd tijdens hun scholing. De informele verzorger heeft volgens beleidsmakers een sociale relatie en emotionele binding met de zieke. De professional heeft afstand en de verzorger is betrokken. Op basis van deze verschillen steunt de professional de informele verzorger. Hoewel verzorgers steun ontvangen, definiëren zij deze relatie als een verhouding die niet eenzijdig maar wederkerig ondersteunend is. Zij zorgen er immers voor dat professionals hun arbeid kunnen verrichten, geven hen complimentjes of zwijgen over onvrede met situaties. Een ander belangrijk verschil zit in de definiëring van de aard van hun relatie. Terwijl beleidsmakers deze harmonisch laten zijn, zou de relatie tussen professional en informele verzorger volgens verzorgers een relatie zijn waarin spanningen en ambivalentie overheersen. Dit hoofdstuk toont een gender-conventie in de beschrijving van de kwaliteiten van verzorger in vergelijking tot de professional en in de beschrijving van hun relatie.

In het slothoofdstuk bespreek ik de betekenis van de conventies in beleid voor de praktijk van informele zorg. I laat zien dat beleidsmakers informele zorg niet alleen aanmoedigen, maar impliciet ook definiëren wat goede zorg is en hoe een informele verzorger zich behoort op te stellen om een succesvol verzorger te zijn. Paradoxaal genoeg wordt de informele verzorger geprofessionaliseerd. En dit betekent dat verzorgers kenmerken moeten gaan vertonen die geassocieerd worden met mannelijkheid. De succesvolle verzorger handelr niet intuitief, maar op basis van kennis. Ze is niet betrokken, maar houdt afstand en geeft bovendien duidelijk haar zorgproductie aan. De taal en conventies van beleidsmakers komen grotendeels overeen met die van wetenschappers, maar verschillen van verzorgers. Terwijl verzorgers zorg uitdrukken in termen van relaties, verbinden beleidsmakers zorg aan 'instrumentaliteit'. Zo wordt informele zorg steeds meer een kwestie van ratio, methode en produktie. Deze bevinding koppel ik aan een maatschappelijke rendens die bekend is onder de naam 'managementisme' en waarin instrumenteel taalgebruik overheerst. Ik wijs op de gevaren hiervan voor de praktijk van de informele zorg en houd een pleidooi om sociale (vrouwelijke) waarden in het informele zorgbeleid (her) te waarderen en vast te leggen. 



\section{Summary}

From the eighties onwards the Dutch governement has been stimulating extramural care, promoting domestic and informal care at the cost of intramural and professional care. The dissertation investigates how the authorities promote the development of informal care. How do policy makers intervene in the privacy of people? How do they influence exiscing kinship relations? The dissertation describes the relation between government policy and informal care.

The analysis provide above all insight into the normative character of informal care policy, revealing the implicit assumptions or conventions of this policy. Because of the sex-specific character of informal care, special attention has been paid to gender conventions. Which self-evident assumptions related to thinking about men and women, or masculinity and femininity, are used bij policy makers? In other words: which gender conventions are produced bij policy makers in their informal care policy? The purpose of this research is to determine the significance of the use of gender conventions in informal care for the practice of informal care.

In order te research this normative character of informal care policy, policy statements on informal care have been compared with texts by academics and bij carers themselves. After alle policy makers use scientific knowledge to corroborate their policy. In doing so they intend to solve problems affecting citizens or the carers. They try at any rate to provide answers to questions pur by the carers and to share their concerns. Academic and carers are therefore vital to the development of this policy.

By comparing these policity guidelines and documents of academic and carers, the dissertation provides an insight into the interrelation. It shows to what extent policy incorporates conventions of academic and citizens. The comparison produces also distances, surprise and reflection. It provides insight into the question where they differ from another. Consequently I presume on the one hand that language of policy makers has been preconditioned; policy texts carry conventions of other language users. On the other hand the same language offers room to the policy makers to break through stereotypical conventions which for example confirm current man/woman or gender images. Thus the differences discovered offer policy makers an alternative vocabulary.

Taking into account the way the research question has been formulated, the investigation straddles the intersection between policy studies and women's studies. The theorerical concepts have been taken from these disciplines. Policy has 
not been conceived as something to do only with policy makers, but is considered a (linguistic) result of the social environment in which it takes shape. This applies to gender just as much. What is considered female or male is not a permanent data, but is constantly being (re)defined in our language. These points of departure, the conepts and method used in this research, are described in Chapter I. In this chapter $I$ also describe the arguments used by policy makers to promote informal care and the manner in which public authorities succeed in influencing private care.

In Chapter 2 policy is compared with academic texts. I answer the question how conventions on informal care have undergone changes in policy, and on the basis of those conventions I distinguish three periods in informal care policy. While in the first policy period carers were described as sex-neutral, and were defined especially as a valuable subsystem within the total health care system, in the second period the sex-specific character of the carers comes more to the fore. Carers are women. Policy makers then ask themselves if, taking into account the increasing numbers of women working, the care system can still count on the commitment of carers. They are afraid that the number of carers will not be sufficient. Finally, in the third period the attention of policy makers shifts from the quantitative shortage of carers to individual capacity. Thus in informal care policy, conventions with respect to carers have changed in two ways. While to start with collective system thinking was central, this gave way to thinking from the perspective of the carer as a female individual. While at first the strenght of the informal care system was emphasized, this was slowly replaced by the inadequacy or weakness of the carer. The focus is on the weak carer. This chapter shows a gender convention in its description of informal carers.

In Chapter 3 I compare the policy texts with stories of the carers. In this chapter I answer the question how policy makers describe the relation between patient and carer. According to the policy makers the patient is a rational subject who chooses to be at home. According to the carers there is hardly any question of choice, but the patients are under strong external compulsion and moral pressure to remain at home or to go home. Why do patients want to be at home? According to policy makers it is at home that they enhance their autonomy. Even if carers do not deny this, they keep pointing to the loss of their own autonomy. After all they have remain at home, giving much of their time to the parient and being at times corrected by professionals. In this way their freedom is restricted. (Male) values which policy makers consider very important for patient like freedom of choice and autonomy, play much smaller part when it comes to policies for carers. This chapter shows the existence of a gender convention or dissymmetry between the description of patient and carer. 
In Chapter 4 I once more compare the conventions in policy with conventions of carers. I answer the question how policy makers describe the relation between professional workers and informal carers. According to the policy makers the professional acts on the basis of universal knowledge and expertise, emplying a rational-methodical working method. This has been learned during their training. The informal carer, according to the policy makers, has a social relation and an emotional bond with the patient. The professional worker observes a certain distance, while the carer is involved. On the basis of these differences the professional supports the informal carer. In spite of receiving support, the carers define this relation as one which is not onesidedly but mutually supportive. For they see to it that professional can do their work, pay them compliments, or keep silent about their discontent with certain situations. Another important difference is found in the definition of the character of their relation. While policy makers describe this relation as harmonious, according to the carers this relation is dominated by tensions and ambivalence. This chapter shows a gender convention in the description of the qualities of the carer in comparison with those of the professional, and in the description of their relation.

In the final Chapter 5 I discuss the significance of conventions in policy for practice of informal care. I show how policy makers not only encourage informal care, but also implicity define what is good care, and what the atritudes of a carer should be in order to be succesful. Paradoxically the informal carer is professionalized. Which means that carers have to develop characteristics which are associared with masculinity. The succesful carer is one who does not act on intuition, but on basis of knowledge. She is not involved, but keeps her distance, and moreover very explicit about her care product. The language and conventions of policymakers are generally similar to those of academics, but differ from those of carers. While carers express care in terms of relations, policy makers link care with 'instrumentality'. In this way informal care becomes more and more a question of rationality, method and production. This conclusion I connect with a social trend towards 'managerialisme', in which instrumental use of language predominates. I point out the dangers of this for the practice of informal care and plead for social (feminine) values to (re)assessed and consolidated in informal care policy. 


$$
\text { , }
$$




\section{Curriculum Vitae}

Saskia van der Lyke is geboren op II oktober 1963 te Hoek (Zld). Na het behalen van haar vwo-diploma aan de toenmalige Rijksscholengemeenschap Petrus Hondius in Terneuzen, studeerde ze Verpleegkunde aan het IHBO te Eindhoven. Ze slaagde cum laude, waarna ze als (wijk)verpleegkundige werkzaam was. Van 1987-1991 studeerde ze Gezondheidswetenschappen aan de Universiteit van Maastricht. Haar afstudeerrichtingen waren Theorie van de Gezondheidswetenschappen en Verplegingswetenschap. Van 1992 toc 1995 was ze full-time als AIo werkzaam bij de vakgroep Beleidswetenschap van de Universiteit Maastricht. Deze baan combineerde ze vanaf 1995 met een baan als hogeschooldocent bij Fontys Hogeschool voor Verpleegkunde. Vanaf 1997 is Fontys haar enige werkgever. Sinds kort is ze deels gedetacheerd naar de divisie Verplegingswetenschap van de Universiteit Utrecht. 
Sinds de jaren tachtig pleit de overheid ervoor dat zorgarbeid voor hulpbehoevenden verplaatst wordt van de zorginstellingen, zoals verpleegtehuizen, naar de privésfeer van de burgers.

Hiertoe ontwikkelt de overheid beleid dat een beroep doet op de 'eigen verantwoordelijkheid' van die burger. In Georganiseerde liefde wordt dit overheidsbeleid en de gevolgen voor de mantelzorgers wetenschappelijk geanalyseerd. Omdat de informele zorg vooral door vrouwen wordt gegeven besteedt de auteur in haar onderzoek speciaal aandacht aan vooronderstellingen in het overheidsbeleid die samenhangen met het denken over mannen en vrouwen.

Saskia van der Lyke geeft antwoord op de vraag hoe de overheid informele zorg beïnvloedt, aanmoedigt en controleert. Naast de beelden en (voor)oordelen van de beleidsmakers komen ook verzorgers van patiënten met kanker zelf aan het woord.

Saskia van der Lyke is verpleegkundige en gezondheidswetenschapper. Ze was als AI0 verbonden aan de Vakgroep Beleidswetenschap van de Universiteit Maastricht. Op dit moment is zij werkzaam als docent van Fontys Hogescholen Verpleegkunde en deels gedetacheerd naar de divisie Verplegingswetenschap van de Universiteit Utrecht. 